University of Louisville

ThinkIR: The University of Louisville's Institutional Repository

Electronic Theses and Dissertations

$5-2006$

\title{
A proposed evolution of immigration model applied to the United States, Germany, and Russia.
}

Amy C. Cappiccie

University of Louisville

Follow this and additional works at: https://ir.library.louisville.edu/etd

\section{Recommended Citation}

Cappiccie, Amy C., "A proposed evolution of immigration model applied to the United States, Germany, and Russia." (2006). Electronic Theses and Dissertations. Paper 205.

https://doi.org/10.18297/etd/205

This Doctoral Dissertation is brought to you for free and open access by ThinkIR: The University of Louisville's Institutional Repository. It has been accepted for inclusion in Electronic Theses and Dissertations by an authorized administrator of ThinkIR: The University of Louisville's Institutional Repository. This title appears here courtesy of the author, who has retained all other copyrights. For more information, please contact thinkir@louisville.edu. 


\title{
A PROPOSED EVOLUTION OF IMMIGRATION MODEL APPLIED TO THE UNITED \\ STATES, GERMANY, AND RUSSIA
}

\author{
by \\ Amy C. Cappiccie \\ B.A., Psychology, Kentucky Wesleyan College, 1997 \\ M.S.S.W., University of Louisville, 1999
}

\begin{abstract}
A Dissertation
Submitted to the Faculty of the

Graduate School of the University of Louisville

in Partial Fulfillment of the Requirements

for the Degree of
\end{abstract}

Doctor of Philosophy

Kent School of Social Work

University of Louisville

Louisville, Kentucky

May, 2006 
A PROPOSED EVOLUTION OF IMMIGRATION MODEL APPLIED TO THE UNITED

STATES, GERMANY, AND RUSSIA

by

Amy C. Cappiccie

B.A., Psychology, Kentucky Wesleyan College, 1997

M.S.S.W., University of Louisville, 1999

A Dissertation Approved on

April 10, 2006

By the following Dissertation Committee:

Thomas Lawson, Ph.D., Chair

Pamela Yankeelov, Ph.D.

Joseph Brown, Ph.D.

Steven Drewry, Ph.D.

James Clark, Ph.D. 


\section{DEDICATION}

This dissertation is dedicated first to the Lord who has guided me to this place in my life. Triumphs and tribulations have shaped who I am always guided by his hand. The Lord placed a mother of no compare in my life to uplift me on to higher and higher levels of education. Her courage, strength, and guidance show me an example of what I want to continue to strive for in my own life. My father and sister have helped to encourage me also along the way. I have been fortunate to have a wonderful group of friends of which I do not know how I would have survived the many trials and tribulations throughout the doctoral process without their loving

encouragement and support. My 2003 cohort helped to push me along when school work, work, and life just seemed too much during the long doctoral process. I am forever grateful to all those that I call family and friend for your piece in shaping who I am today. 


\section{ACKNOWLEDGMENTS}

The author wants to express my gratitude to Dr. Thomas Lawson for his true and unfailing commitment to international social work. His passion for cross-cultural studies is truly a blessing to students. Under his support and guidance, I decided to write a dissertation that is cross-cultural in nature. It is my sincere hope that Dr. Lawson, along with the support of his wife, Judy Lawson, continues to provide an incomparable way to learn in the field through international student exchanges.

The author would also like to thank the other members of my dissertation committee, Pamela Yankeelov, Ph.D., Joseph Brown, Ph.D., Steven Drewry, Ph.D., and James Clark, PhD for their constructive criticism, guidance, and support.

Others whose support has been greatly appreciated throughout my doctoral studies include: Amy Doolittle for being my qualifying exam study buddy and guru to instruction on the table of contents, Ramona Stone, Ph.D. for her support; Ruth Huber, Ph.D. for her "eagle eyes"; Dana Sullivan, Ph.D. for her gems of wisdom; Sharon Moore, Ph.D. for her positive view on daily life; and Norma Niev for her unfailing sense of humor. The staff at the Kent School of Social Work has absolutely been a joy to work with. Your laugher and support has helped to make this last two years a period of growth. I wish all of Kent's staff best wishes for the future. 


\section{ABSTRACT \\ A PROPOSED EVOLUTION OF IMMIGRATION MODEL APPLIED TO THE UNITED STATES, GERMANY, AND RUSSIA \\ Amy C. Cappiccie}

April 10, 2006

This exploratory study proposes a model for examining the evolutionary nature of immigration policy, the Cappiccie Lawson Evolution Immigration Model (CLEIM). The model was applied to the United States, Germany, and Russia to provide a broad variety of immigration policy history. CLEIM, as applied to the United States, examined policy from 1882 to the present. CLEIM, as applied to German policy, examined policy from World War II to the present and Russian policy from post-Communism to present.

Section I of this paper presents the proposed Cappiccie Lawson Evolution of Immigration Model (CLEIM). Sections II, III, and IV apply CLEIM to the United States, Germany and Russia immigration policy. Section V explores the commonalities between the United States, Germany, and Russia. This comparison enhances the understanding of similarities and differences in immigration policy change and implementation cross-culturally. In addition, this comparison section aids in understanding the influence of world events on change. Suggestions for the use of viewing immigration theoretically are addressed. The strengths of weaknesses of CLEIM are addressed and suggestions for the future use of this model are provided. Section VI explores the role of social work in immigration and immigration policy in the past and suggests ideas for future profession involvement. 


\section{TABLE OF CONTENTS}

PAGE

DEDICATION

ACKNOWLEDGMENTS

ABSTRACT

iii

LIST OF TABLES AND FIGURES

INTRODUCTION

Current Immigration Policy Literature

The Significance of Immigration Policy Study

Research Questions

Methodology

CHAPTER I: Cappiccie Lawson Evolution Immigration Model

Factors that Influence Public Policy

Public Policy Factors: Application to Immigration Policy 20

Exploration of Proposed Model of Immigration Policy 24

Ways to Examine the CLEIM Model as Applied to Individual Policy 30

CHAPTER II: Application of CLEIM to United States Policy 32

United States Immigration Policy Perspectives $\quad 32$

Goals of Chapter $\quad 34$

A Basic Overview of United States Immigration Policy $\quad 34$

Specific Immigration Policy Analysis $\quad 39$

$\begin{array}{ll}\text { The Chinese Exclusion Act of } 1882 & 39\end{array}$

The Gentlemen's Agreement of 1906 and $1907 \quad 46$

Immigration Act of 1917

Immigration Act of 1921 
$\begin{array}{ll}\text { Immigration Act of } 1924 & 57\end{array}$

$\begin{array}{ll}\text { Smith Act of } 1940 & 60\end{array}$

McCarran Walter Act of 1952

Hart Cellar Act/ Immigration Act of 1965

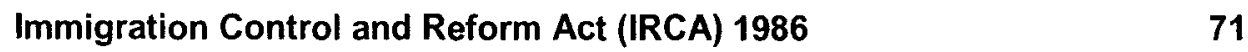

$\begin{array}{ll}\text { Immigration Act of } 1990 & 74\end{array}$

Violent Crimes Control and Law Enforcement Act 1994

Illegal Immigration Reform Immigration Responsibility Act $1996 \quad 78$

$\begin{array}{ll}\text { Changes around September 11, } 2001 & 81\end{array}$

Homeland Security Act $2002 \quad 82$

$\begin{array}{lr}\text { Current Immigration Policy Concerns } & 85\end{array}$

CHAPTER III: Application of CLEIM to Germany $\quad 86$

$\begin{array}{ll}\text { The German Concept of Citizenship } & 87\end{array}$

$\begin{array}{ll}\text { The Formation of the German Government } & 88\end{array}$

Current Settlement of Migrants within German States $\quad 89$

$\begin{array}{ll}\text { Overview of German Migration Periods } & 91\end{array}$

$\begin{array}{ll}\text { Ethic German Law or Aussiedler Law } & 99\end{array}$

$\begin{array}{ll}\text { Guest Worker Law or Gastarbeiters } & 105\end{array}$

Foreigner Law (Auslanderpolitik) $\quad 111$

Germany's First Immigration Policy: Zuwanderungsgesetz $\quad 121$

CHAPTER IV: Application of CLEIM to Russia $\quad 123$

The Beginning of Russian Migration History $\quad 123$

Russian Federation Migration Policy since the End of Communism 132

Emigration: The Freedom of Movement Policy (1991) 132

$\begin{array}{ll}\text { Citizenship Law (February 1992) } & 136\end{array}$

Immigration Control Act (1993) 138

Law on Entry/Exit from Russia (1996) 141

Law on Judicial State of Foreigners (2002) 143 
$\begin{array}{ll}\text { Future Policy Ideas } & 148\end{array}$

CHAPTER V: Exploration of the Research Questions as a Cross-Cultural $\quad 149$ Comparison

The Role of Future Influence Groups on Policy Decisions $\quad 149$

The Role of Policy Changers on Policy 152

Trigger Events: Influence on National//nternational Policy $\quad 155$

World War I (1914-1917) 156

$\begin{array}{ll}\text { The Russian Revolution } & 158\end{array}$

$\begin{array}{ll}\text { The Great Depression } & 158\end{array}$

World War II (1939-1945) 160

The Cold War Years (1946-1991) 163

$\begin{array}{ll}\text { OPEC Oil Crises } & 164\end{array}$

Collapse of USSR (1991) $\quad 166$

The World Rise of Terrorism: September 11, 2001

$\begin{array}{ll}\text { Policy Response Continuum Exploration } & \mathbf{1 7 0}\end{array}$

$\begin{array}{ll}\text { The Role of Theory to Inform Policy } & 171\end{array}$

$\begin{array}{ll}\text { Application of Theory to CLEIM } & 175\end{array}$

$\begin{array}{ll}\text { The CLEIM Analysis } & 178\end{array}$

$\begin{array}{ll}\text { Future Uses of CLEIM } & 180\end{array}$

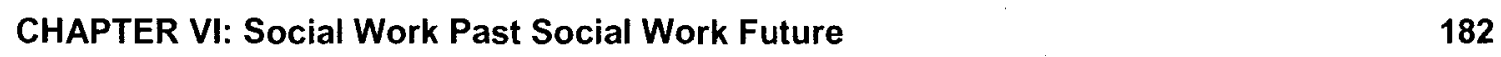

$\begin{array}{ll}\text { America Adjusts to Change } & 183\end{array}$

$\begin{array}{ll}\text { Social Work: Alleviating Poverty } & 183\end{array}$

$\begin{array}{ll}\text { Current Portrait of Global Migration } & 186\end{array}$

$\begin{array}{ll}\text { Future Ways to Alleviate Migration Troubles } & 189\end{array}$

Social Work: The Answering for Filling the Gap for Future Migration 191

$\begin{array}{ll}\text { REFERENCES } & 195\end{array}$

APPENDIX A: Figure 1. Cappiccie Lawson Evolution Immigration Model 215

APPENDIX B: Table 1. Index of Immigration 216 
APPENDIX C: Table 2. Model of Admissions and Rights

APPENDIX D: Table 3. Magazine Cover Themes by Year

APPENDIX E: Table 4. Non-Immigrant Visa Types

APPENDIX F: Table 5. Media and Economic Connection

APPENDIX G: Table 6. U.S. Policy History and Status Quo Attitudes

APPENDIX H: Table 7. German Policy History and Status Quo Attitudes

APPENDIX I: Figure 2. Map of Germany

APPENDIX J: Figure 3. Subjects of the Russian Federation

APPENDIX K: Figure 4. Russian Federation and Surrounding Countries

APPENDIX L: Table 8. Russian Actors and Influence Groups

APPENDIX M: Table 9. Russian Policy History and Status Quo Attitudes

APPENDIX N: Table 10. Trigger Events on Policy (1914-1939)

APPENDIX O: Table 11. Trigger Events on Policy (1939-1973)

APPENDIX P: Table 12. Trigger Events on Policy (1973-present)

APPENDIX Q: Figure 5. United States Policy Response Continuum

APPENDIX R: Figure 6. German Policy Response Continuum

APPENDIX U: Table 14. Preparation at Practice, Education, and Policy Levels 


\section{INTRODUCTION}

Many countries analyze individual immigrant characteristics to provide a "portrait" of the current immigration picture. Copious information is gathered to include numbers of documented versus undocumented immigrants, individual characteristics of immigrants, and regions in which immigrants settle in the host country. Headlines and graphs reporting these statistics are found in newspapers and television reports on a regular basis. Some headlines are accurate and portray the facts while others sensationalize the topic of immigration.

Behind a country's "portrait" of immigration lays the policy that determines specific aspects of immigration. Policy sets regulations such as the number of migrants to enter/exit a country, characteristics of people allowed to access the country, acceptable reasons to enter the country, and rules for exit from the country.

This study's introduction contains a four fold purpose: to report available immigration literature, to identify gaps in current immigration literature, to discuss the need of further immigration policy study, and to purpose a plan for the development of a new model to study immigration policy. To meet this four fold purpose, this introduction begins with an exploration of the current literature in the field of immigration policy. After understanding today's available immigration policy literature, the basics are provided for immigration in the United States, Germany, and Russia. The increasing numbers of migrants are reported for each of these countries suggesting the need for further cross-cultural immigration policy studies to fill a gap in the current literature. To begin the formation of a new examination model, this introduction proposes research questions to guide the exploration of a new model. A description of the methodology is supplied.

Current Immigration Policy Literature 
To tease out the gaps in the current immigration policy literature, an examination of the available literature on the topic is appropriate. Current literature on immigration policy is organized into three distinct categories: a) individual country immigrant and immigration literature, b) country policy comparisons, and c) examination of explanatory immigration theory. Individual Country Literature

This study focuses on immigration policy in the United States, Germany, and Russia. Individual country literature is readily available on all three of these countries. A "snapshot" of the basic individual country information is provided below.

United States snapshot.

A preponderance of literature focuses singularly on United States immigration policy. A brief summary of early United States immigration policy is provided for the reader to examine a sample of the current available United States literature.

The portrait of early United States immigration policy reveals a picture of change based on the attitudes and beliefs prevalent in the time period under examination (Buck et al, 2003; Churgin, 1996; Daniels, 2004; Esses et al, 2001; Lipset, 1955; Sanchez, 1997; Schmid, 2003). In the 1880s, Daniels (2004) asserts that anti-Asian sentiment increased with the passing of laws in California to deny certain rights to Asians such as land ownership, anti-miscegenation laws, and the criminalization of opium. Over a period of time, these restrictive state laws culminated in the Chinese Exclusion Act of 1882. This act was the first United States exclusionary policy targeted toward a specific nationality of people (Daniels, 2004).

The rise of American Protective Association (APA) and the Know-Nothing Party were attempts in the late 1880 s to decrease the number of Catholic immigrants entering the United States (Lipset, 1955). The Progressive Movement, from 1900 to 1912, attempted to rid the nation of persons not of White Anglo Saxon Protestant (WASP) values. The Immigration Act of 1917 codified previous immigration laws and added a literacy test as a determinant of entrance into the country. Continued anti-Asian sentiment was noted in the creation of an "Asiatic bar zone" to exclude all Asian immigrants (Daniels, 2004). 
The 1920 s noted the rise of the Ku Klux Klan's (KKK) strident voice against minority races (Lipset, 1955). The American Federation of Labor (AFL) encouraged more restrictive immigration policies for fear of the threat to working class Americans (Sanchez, 1997). The Immigration Acts of 1921 and 1924 used progressively earlier Census data to set quotas for the numbers of immigrants from each country; thus increasing the numbers of immigrants of WASP backgrounds (Schmid, 2003).

Policy from 1965 to the present has focused on political rather than social needs (Daniels, 2004). This has played out as allowing entrance to workers deemed needed most by United States economic trends.

German snapshot.

Three separate terms are associated with German migration: auslander, gastarbeiter, and aussiedler. Auslander is the generic term for foreigners coming to Germany. These foreigners enter Germany to work, attend school, and vacation. This type of visa is for a specific amount of time and upon expiration the person is expected to leave the country. Little integration is expected into German society since the goal is for these individuals to leave the country after the expiration of the visa (Kurthen, 1995).

A gastarbeiter or guest worker is the term used for people who were brought to Germany to work from 1960 to 1973 on a rotation system. Workers were expected to fill open labor market positions for 1 to 3 year periods and then return to their homelands (Kurthen, 1995). Early recruitment was mainly from Italy, Spain, Portugal, and the former Yugoslavia whereas later recruitment was mainly from Morocco, Algeria, Tunisia, and Turkey (Fassman \& Munz, 1992). This policy idea failed and as a result large numbers of guest workers continue to live and work in Germany. In 1973, the German government recognized the problems inherent with this program and thus stopped active recruitment of workers. Ceasing recruitment led to stabilization but not a decrease in the populations of foreigners (Kurthen, 1995).

Aussiedlers or German re-settlers are individuals who migrated to Germany as full citizens due to having German ethnicity (Kurthen, 1995). These re-settlers mostly arrived from Poland, Russia, and the former Czechoslovakia. At different points in history, these lands were 
within German borders. The unexpected numbers that returned to Germany left the government unprepared. Beginning in 1990, re-settlers had to apply and receive approval to enter the country. In 1992, an annual cap was placed on the numbers of aussiedlers accepted per year (Kurthen, 1995).

Russian snapshot.

Russia has noted an increase in emigration since 1990-1991 due to the liberal political regimes' connection with the West during the Perestroika period (Shevtsova, 1992). Russia first officially opened her borders on January 1, 1993 (Brubaker, 1991). Individuals that exited Russia were of two distinct groups: (a) families reuniting with ethnic homelands (i.e. German's by ethnicity) and (b) separate ethnic groups of previous discrimination reuniting (i.e. Jewish individuals) (Shevtsova, 1992).

Due to the unequal numbers entering and exiting certain parts of Russia, the government attempted to institute a regional resettlement program (Ardittis, 1995). Regional resettlement programs encourage new immigrants to inhabit specific areas of the country to increase the inhabitants in areas that lost many Russian citizens due to emigration by offering jobs and housing opportunities.

From the mid to late 1990 s, Russian immigration policy focused on four main areas: (a) the development of comprehensive refugee and labor immigration policies, (b) the study of determinants of Russian migration and investment of potential Russian migration, (c) the reexamination of regional resettlement policy, and (d) the training of personnel to adequately implement immigration policy under the newly formed Institute for Immigration Control (Ardittis, 1995).

\section{Comparisons between Countries}

The second area of current immigration policy literature is between country comparisions. While this section is not meant to be an exhaustive search of the literature, the reader should take note of the countries that are typically compared as well as the topics that are the focus of comparison in the current literature. The literature reviewed provides an overview of the most common themes in current writings. 
The comparisons between Germany and the United States appear most common in immigration comparisons. Weiner has edited an assortment of books comparing the United States and German immigration and Immigration Policy. Topics of these comparisons include: cross-cultural history, treatment of refugees, foreign policy agreements, immigration admissions, and inclusion procedures. Further work has focused on assimilation procedures within the United States and Germany as a way to decrease the allotment of welfare provisions (Kurthen, 1996; Faist, 1995).

Open immigration country comparisons are noted in the literature. Yale-Loehr \& HoashiErhardt (2001) studied attempts by Australia, Canada, and the United States to draw more highly skilled and educated migrants. Jenks and Lauck (2003) examined the similarities and differences between the immigrant rečeiving countries of the United States, Australia, and South Africa. Boyd (1976) examined immigration policy trends between the United States and Canada in the 1970s. Simon \& Lynch (1999) compared attitudes toward immigrants and immigration policy in Australia, Canada, France, Germany, Great Britain, Japan, and the United States.

Comparisons involving European Union countries are increasing in popularity. Martin (1994) provided a cross cultural comparison of European countries such as France, Germany, Italy, and Great Britain. Similarities were found between the mid-1990s immigration in Europe and the immigration characteristics in the United States in the late 1970s. Dell'Olio (2004) investigated difficulties in European Union immigration policy due to specific housing policies in Italy and the United Kingdom.

\section{Explanatory Theories of Immigration}

The third area of current immigration literature centers on explanatory theories of attitudes toward migrants and migration theory. Both types require examination since influence groups and the attitudes of influence groups are part of the proposed model of this paper's research.

Theory of attitudes toward immigrants.

Theory concerning attitudes toward immigrants is divided into the following categories: contact theory, in-group/out-group theory, and group threat theory. 
Contact theory proposes that lack of intimate contact is the main predictor of levels of prejudice and discrimination. As intimate contact decreases, higher levels of prejudice and discrimination ensue. Intimate contact is characterized as contact in which people from the dominant group have close immigrant friends in a neighborhood and home setting. This type of contact moves beyond the mere acquaintance phase to more regular, close interaction. Contacts in a work or school situation do not satisfy the definition of intimate contact due to the lack of close interaction. Research concerning contact theory provides conflicting results in studies within the United States (McLaren, 2003).

In-group/out-group theory explores the relationship between groups in which a person is involved versus groups in which a person is not involved. Groups might be ascribed for example race, gender, and citizenship or volitional groups such as religion and work associations. Outgroups include both ascribed and volitional groups that are different from those which a particular individual embraces. A positive correlation between out-group bias and prejudice is noted in the literature (Lee \& Ottati, 2002). Perception is instrumental in determining which groups a person considers different enough to harbor feelings of prejudice or discrimination. A positive relationship exists between in-group cohesion and prejudice to immigrants (Zarate et al., 2002).

Quillian (1995) explains that group threat theory involves the relationship between the immigrant group size (S) and the country's economic situation (E). To determine the level of threat $(T)$ the formula is as follows: $T=E+S$. Although threat does affect the individual level, this theory focuses on macro threat effects perceived by a large group such as a community, a city, a state, or a nation. According to Bachman, Ybarra, and Stephan (1999), threat might involve: realistic threat, symbolic threat, inter-group anxiety, and negative stereotypes. Realistic threat entails occurrences that threaten dominant group existence. Symbolic threats involve diversity of personal characteristics such as morals and values. Inter-group anxiety is influenced by problems such as an antagonistic history, personal contact, level of ethnocentrism, level of difference between out-group and in-group, knowledge concerning the new group, level of competition, and status of the new group. Negative stereotypes increase levels of prejudice and discrimination. Threat is compounded by zero-sum beliefs or the idea that as one group obtains higher status 
another group decreases in status through competition (Esses et al., 2001). Areas of competition include: job opportunities, social rights, economic situations, neighborhood disputes, differences in health care, and differences in quality of life (Tougas et al., 2003).

\section{Migration theory.}

Migration theory emphasizes the unique combination of elements that form together to contribute to an individual or family choosing to migrate from his/her home country to a foreign land. Elements to study for gathering a complete understanding of the reasons behind a choice to migrate include: (a) structural forces in developed nations that attract immigrants (pull factors), (b) structural forces in nations that promote emigration (push factors), (c) motivations, goals, and aspirations of the migrant, and (d) social and economic structures that connect migration out of, and into, each country (Massey, 1999).

Pull factors comprise benefits that migrants see as desirable in another country. Typical pull factors include job availability, amount of job pay, safety, family present in the host country, and social service availability such as health care, food assistance, and financial assistance (Massey, 1999).

Push and pull factors combine to provide a unique set of motivations for each immigrant that are compounded by the social and environmental connections between countries (Massey, 1999). Motivations are different depending on whether the immigrant is a single person migrating, a family migrating together, or a family chain migrating one after another. Social and economic connections between countries push or pull migrants to particular countries. For example the open borders in the European Union lead to ease of migration between member countries in order to meet individual motivational needs (Massey, 1999).

\section{The Significance of Immigration Policy Study}

The lack of unified research on immigration policy is compounded by the increasing numbers of migrants throughout the world. As previously discussed, research surrounding immigration policy is fragmented into four separate areas of study. Vacillation between how best to implement immigration policy leaves individual countries with difficult decisions which are influenced by the current ebbs and flows of the populaces' beliefs, of that time period, in which to 
write and implement immigration policy. Without the mindset to continually examine policy for efficiency and effectiveness, it is easy for individual countries to write and implement policy that is retroactive to national events and thus influenced by the current belief structure of the time period. Policy that is not written and implemented using thorough analysis has the increased likelihood of being detrimental to both the host country and the immigrant alike. In addition, policy decisions mainly influenced by the populaces' belief structure can discriminate against particular groups of people on the basis of race, gender, creed, disability, sexual orientation, religion, and etcetera.

The need for a unifying model to study immigration is further solidified by the increasing numbers of migrants that will continue to add pressure on immigrant receiving countries (Brubaker, 1991). Mounting pressure will be compounded by four push factors: the increasing division between the economies of affluent and underdeveloped nations, the rising working age population pressing for labor market entry, the increasing urbanized population leading to closer linkages between countries, and the rising effect of ecological factors as a push factor for migration. These push factors encourage individuals to settle in open immigration countries such as the United States, Canada, and Australia as well as increasingly Eastern and Western Europe. As a response, host nations respond to large numbers of migrants by increasing internal and external controls. Internal controls include limiting access to settlement, work, the welfare system and system surveillance, information and identification. External controls include restriction of entry such as closer inspection of passports and visas as well as border protection and control.

The present situation, without international agreement on immigration policy, has created an asymmetric relationship between national sovereignty and immigration human rights (Plaut, 1995). As numbers of migrants steadily grow and restrictive policies increase in open immigration countries, the international community will be forced to make decisions on how best to handle a growing international phenomenon (Trebikock, 1996). A unifying model of analysis could be helpful for future analysis needed to make international level policy decisions. 
To help the reader have a clear picture of the numbers of migrants applicable to a study of the United States, Germany, and Russia, the following section will provide current country specific details concentrating on the increasing migration numbers.

United States Numbers

In the United States, the Center for Immigration Studies asserts that approximately 1.3 million immigrants, both documented and undocumented, arrived in the United States yearly through the 1990s. Figures from January 2000 to March 2002 reported that an additional 3.3 million immigrants traveled to the United States. The current "portrait" estimates a total of 33 million immigrants or $11.5 \%$ of the total population of the United States. The number of undocumented immigrants is suggested to be between 8-9 million. A recent study by the Pew Hispanic Center estimated the number of undocumented immigrants to be as high as 11 million.

The Center for Immigration Studies reports that approximately 11 to 22 billion dollars a year is paid to support immigrants by state and local budgets. This is somewhat offset by the taxes paid to the United States by documented and undocumented immigrants. Specific states are under larger fiscal strains due to the levels of undocumented migration. The state of California estimates approximately 3 billion dollars per year used for care of undocumented immigrants (i.e. hospital, social services, and public school).

\section{German Numbers}

From the mid to late $1990 \mathrm{~s}$, it is estimated that 3.4 million auslander (foreign visitors) entered Germany. Some of these visitors exited the country, as expected, while others did not (Kurthen, 1995). The highest percentages of auslander are of Turkish nationality followed by Greek, Russian, and Central/Eastern European (Fasman \& Munz, 1992). Martin (1994) suggests that approximately 1 million gastarbeiters (guest workers) are still living in Germany; thus making up approximately $2 / 3$ of current foreigners. Approximately four million aussiedler (German resettlers) migrated to Germany from the late 1980 s to early 1990 s (Kurthen, 1995).

\section{Russian Numbers}

Increasing numbers of undocumented immigration are found in larger cities and border areas of Russia (Kastnets, 2005). Estimates of 4.5 million migrants, mostly from China, Vietnam, 
and Afghanistan, cross the borders between China and Russia, Mongolia and Russia, and Kazakhstan and Russia. Characteristics of immigrants include: approximately $69.7 \%$ are male; $80 \%$ are Afghans; an average age of 34 years; lack of work experience from home country; $40 \%$ send money to home country; most are from the poorest segments of home country; and $79.8 \%$ have informal jobs within Russia.

\section{Research Questions: Filling the Gap in Cross-Cultural Immigrant Policy}

A cross cultural model is needed to lay the groundwork for understanding immigration policy: a) across periods of time and b) across different countries. The proposed model for examining immigration policy allows for analysis both over time by individual country and by cross-cultural comparisons. This model can be used as a tool to enable future international migration policy decisions to alleviate the increasing strain on open immigration countries throughout the world. In addition, proposing a new model for immigration study will provide a tool to fill the gap in the current literature. This study addresses the following research questions to pose a new model:

1. What role do influence groups play on influencing immigration policy in the United States, Germany, and Russia?

2. What role do policy changers play on immigration policy in the United States, Germany, and Russia?

3. What role do trigger events have on national and international immigration policy in the United States, Germany, and Russia?

4. What theories help to inform immigration policy decisions in the United States, Germany, and Russia?

5. Does the proposed model accurately explain the evolution of immigration policy in the United States, Germany, and Russia?

6. Does the proposed policy response continuum (from inclusion to exclusion) aid in understanding immigration policy decisions in the United States, Germany, and Russia? 
What role did social work have in the past concerning immigration and/or immigration policy in the United States, Russia, and Germany?

8. What role can social work play in the future of immigration and immigration policy?

\section{Methodology}

This exploratory study will propose a model for examining the evolutionary nature of immigration policy. The model will be applied to policy in the United States, Germany, and Russia to provide examples of countries with diverse immigration and immigration policy histories. The United States is considered a country of long-term immigration and one of the few open immigration countries in the world. German immigration has only significantly occurred since World War II. Currently, Germany experiences the largest numbers of migrants in the European Union and as such has been forced to re-invision their role as a country of migration. Russian decisions concerning official immigration policy has only occurred since the fall of Communism in the early 1990 s and, as a result, continues to struggle with both the numbers exiting the country, and those entering without documented status.

Chapter I of this paper will present and discuss the formation of the proposed Cappiccie Lawson Evolution of Immigration Model (CLEIM). Chapters II, III, and IV will involve application of CLEIM to the United States, Germany and Russia. Policy examination of the United States will begin in 1882 with the Chinese Exclusion Act. Policy examination in Germany will begin post World War II. Policy examination in Russia will begin after the end of Communism (early 1990s). This analysis provides policy by policy discussion for each country and, as a result, individual policy exploration will look at research questions one thru three by applying policy elements of CLEIM (influence groups, policy changers, trigger events, and national/international events) to each policy. Chapter $V$ will explore model level discussion of research questions one thru three by examining the similarities and differences of CLEIM policy elements (influence groups, policy changers, trigger events, and national/international events) between the United States, Germany, and Russia. In addition, the strengths of weaknesses of the CLEIM model will be addressed (research question 5 and 6). Through the discussion of research question number four, this paper 
will provide an exploration of the most applicable theories to view immigration policy: conflict theory, structural functionalism, economic theory, symbolic interactionism, and migration theory. The basics of each theory will be addressed and then suggestions for application will be provided. Chapter VI will explore research questions number seven and eight by emphasizing the role of social work in immigration and immigration policy, both past and present, as well as offer suggestions for the role of the social work profession in the future of immigration and immigration policy. 


\section{CHAPTER I}

\section{CAPPICCIE LAWSON EVOLUTION OF IMMIGRATION POLICY MODEL}

The purpose of this chapter is to propose a new model for examining the evolution of immigration policy. Before putting forth this model, chapter I will provide information on factors currently known to influence the formation and implementation of public policy: individual factors, group factors, and events as factors. These factors are then transferred to an application of immigration specific policy. The exploration of these factors then allows for the author to choose the most pertinent components in which to form a new model to study immigration policy, the Cappiccie Lawson Evolution of Immigration Model (CLEIM).

\section{Factors that Influence Public Policy}

"In studying public policy, we study individuals, groups, organizations, or government actions that, for better or worse, influence our lives through the creation and implementation of public policy."

(Birkland, 2001, p.5)

Individual Factor Influences

Although the individual level is not consistently a focus of consideration in reference to policy, some literature recommends the importance of individual specific factors due to the influence of the individual level on the group level (Chancler \& Tsai, 2001; Crespic, 1997; Crichlow, 2002).

\section{Characteristics and Experience}

Individual opinions are subjectively formed through a combination of a person's unique characteristics and life circumstances (Crespic, 1997). Unique characteristics are divided into those assigned at birth (ascribed characteristics) and those not assigned at birth (Chandler \& Tsai, 2001). Examples of ascribed characteristics include, for example, age, race, and sex. Nonascribed characteristics include, for example, education and income level. Ascribed 
characteristics influence individual opinions more than non-ascribed characteristics; thus an individual is more likely to have opinions similar to others with the same ascribed characteristics.

Life experiences influence individual opinions in one of two ways: strengthening or weakening (a) core belief(s). If a belief is strengthened, the experience creates an affirming situation that further bolsters the individual's belief(s). If a belief is weakened, the experience creates an uncomfortable clash with a current belief (cognitive dissonance); therefore forcing the individual to reexamine his/her thoughts in that particular area. Re-examination can lead to opinion change based on uncomfortable feelings associated with the tension between a belief and a non-conforming experience (Crespic, 1997).

\section{Framework for Individual Opinion Formation}

To provide further clarification, Crespic (1997) recommends a framework to simplify individual opinion formation. Through the screen of personal characteristics and life experiences, individuals also use the following: a) values and interests, b) cognition, c) affect, and d) behavioral intentions. Values and interests are prioritized through early shaping and innate instinct to what the individual finds most important. It is essential to understand that over time individuals might change priorities which are partially determined by life experiences. A positive correlation exists between level of information (cognition) and strength of opinion. Remember that information on a topic might be gathered from a variety of sources such as friends, family, school, media, movies, etcetera. The quality of the source of information is not necessarily taken into account when shaping opinion. Affect reflects the individual's feeling, whether positive or negative. In a fashion similar to cognition, feelings might be influenced by past experiences, the media, friends, and groups to which the individual belongs. Finally, if an individual participates in activities centering on a specific topic, he/she increases the strength of opinion toward that topic positively or negatively. For example, participation in a march for individuals with AIDS would strengthen positive feelings concerning the topic of HIV and AIDS. Attending a KKK rally might strengthen negative beliefs of white supremacy.

Political Figures as Individuals 
In addition to the average citizen, political leader's voting outcomes are influenced by personal beliefs and ascribed characteristics (Crichlow, 2002). A high level of distrust and desire for power appears to encourage conflictual support of policy as displayed by erratic voting on specific policy agendas. A high level of cooperation and the belief in change appears to encourage cooperative policy support. The influence of personal characteristics on policy decisions increases as individual legislative experience lengthens. In addition, the stronger and more developed the personal belief system the higher the concern for world level policies (Crichlow, 2002).

Interface between Individual and Group Factors

Individual opinions unite to form group opinions through the conduit of communication. Perhaps the formation of opinion groups occurs naturally due to the phenomenon known as the "power of the group". The power of the group is more able to make change than a lone voice calling for large overarching changes (Birkland, 2001).

To help explain the link between individual and group opinion, Theodoulou \& Kofinis (2004) recommend the use of a problem identification process. During the first stage, "perception creation", individual beliefs are formed and changed by observing societal problems; thus leading to a circular process of belief formation. In stage two, "perception formation", individual opinions are solidified due to the connection between personal perception and significant events, issues, and or actions noted in his/her life. In stage three, "decision on political action", the beliefs of individuals connect to form the status quo level (p.106). The status quo supports certain topics and, as such, demands a policy response on specific topics. Topics not supported by the status quo are deemed not significant to receive policy action.

Individuals experience a twofold benefit through connection with a group. First, individuals increase personal understanding of inner thoughts and feelings thereby strengthening his/her values and beliefs. Second, communication and connection with others of similar opinions encourages the strengthening of network support systems (Crespic, 1997).

Group Factor Influences 
Literature on public policy recommends considering the role of the group, the community, the city, the state, the region, and the world as factors influencing social policy (Theodoulou and Kofinis, 2004). Within these divisions, the second type of public policy influence, group factors, are composed of two distinct types: unofficial and official actors (Birkland, 2001).

\section{Unofficial Actors}

Unofficial actors are groups that influence public policy without an official position to formulate and implement policy (Birkland, 2001). Unofficial actors include interest groups, lobbyists, the media, political parties, and think tanks (Theodoulou \& Kofinis, 2004).

Key (1958) notes an increase in special interest groups during the rise of the Industrial Revolution as a way to provide balance to the all powerful government of that time. The growth of unofficial actors triggered an increase in groups with differing levels of power to effect change; thus encouraging later social movements to enhance equality (Birkland, 2001). Differences in power between groups are noted through disparities in possessing money, knowledge, power, and information in which to influence the opinions of legislators. The number of unofficial actors has steadily increased since the 1960s.

Types of interest groups.

Different types of interest groups include: institutional versus membership, and private versus public (Birkland, 2001). Institutional groups include members that belong to a specific organization (i.e. a worker at Toyota). A membership interest group includes members who choose to join and pay dues to participate (i.e. National Association of Social Workers). Private interest groups advocate change for the members of the organization, while public groups advocate for broad based changes for large groups of people.

Not all interest groups easily fit into categories and some groups might fit into more than one category. This is increasingly evident as faith based organizations are growing in power to attempt change in our society (Birkland, 2001).

Interest group influence.

The more recent work of Birkland (2001) expands upon our previous knowledge of agenda setting by adding the idea of special interest groups. All of the potential topics for policy 
formation are included in the "agenda universe" (p.108). As a topic's interest increases, that particular idea moves into the systemic agenda level. At this level, individual topics must compete with other ideas for attention. Special interest groups attempt to intervene and encourage attention on specific issues while hoping to effectively block competing topics from advancing. Special interest groups with more power, money, and connections are in better positions to find policy makers willing to support the policies of that particular group and block policies from competing groups. If a topic is successful in advancing, that particular topic moves into the decision agenda arena. In this arena, the topic is under consideration for policy formation at the institutional, local, state, national, and/or international level.

Change of policy throughout history is influenced by three factors: the powerful influence group agenda, conflicts of status quo, and the country's diversity ratio (Baumgartner \& Jones, 1993). As previously explored, during any snapshot in history, different groups have more power and thus influence to encourage change in specific areas. Currently, in the United States, groups with high levels of power, for example, might include the National Rifle Association, large oil conglomerates, faith based initiatives, and environmental activists. The term "Schattschneider mobilization" is used to explore the use of conflict for the expansion of ideas to ultimately target agenda setting (p. 101). As conflict rises in beliefs of the status quo, groups rally around a topic and the enthusiasm spreads for a specific philosophy. The diversity ratio can entail any characteristic of difference (i.e. race, sexual orientation, religion, age) and the percentages of the particular groups that are pertinent to a topic. If the policy to vote on centers on "what is a marriage", perhaps the most appropriate diversity ratio would focus on sexual orientation or religion.

Birkland (2001) asserts that the sexiness of an issue is important in considering how exciting the topic is to the populace. Is this specific topic one that will draw the attention of the media for one story, for two stories, or for an extended length of time? As sexiness an increase, more attention is focused on that topic; thus making change probable. An example is provided by the in competency noted in the United States Federal Emergency Management Association 
(FEMA) after Hurricane Katrina. FEMA's slow response, noted daily through the media attention, created a sense of urgency for change in the United State's populace.

\section{Official Actors}

Official actors are groups that due to position have been given the power to formulate and implement policy (Birkland, 2001). Official actors in the federal, state, regional, and local governments are influential in the formulation and implementation of policy (Baumgartner \& Jones, 1993).

\section{Official actor influence on policy.}

Downs (1972) offers a model to assist in understanding the influence of policy makers on deciding which policies are implemented. During the pre-problem stage, a particular topic is acknowledged but has not ascended to the forefront as a topic of consideration for policy formulation. An event occurs bringing the specific topic to the alarmed discovery level. As attention increases, government officials examine the expenditures required for this topic to develop into policy. Expenditures include components such as time, money, and manpower. At this point, a topic either gathers more attention gradually declines from public attention. Whether a specific policy receives increased or decreased attention is partially determined by competing policy agendas. All policy ideas cannot receive the same amounts of attention; thus some gather interest while others fall off the radar of the individual/group or nation. In the last stage, the post problem stage, a specific policy is no longer considered worthy of attention in the current agenda setting arena.

\section{Democratic government and policy formation.}

A democratic government structure uniquely shapes public opinion through policy vacillation between an elitist and a populist view (Crespic, 1997). An elitist view exists when the government is responsive to public opinion, but does not consider the views of the public while formulating and implementing policy. A populist view exists when politicians base policy decisions on public opinion rather than political reality. A disconnect has been noted throughout history between these two views of policy agenda setting. Ultimately, in a democratic society, public opinion can only influence governmental decisions rather than force change. To increase 
influence, individuals can carefully consider officials for election, exercise his/her right to vote, and increase the number and power of special interest organizations (Crespic, 1997).

\section{National Factor Influences}

The $3^{\text {rd }}$ type of factor influence, national level influences, impinge on public policy decisions. Perhaps this is most evident in the connection between form of government and policy decisions. The government structure of a country guides the policy agenda (Money, 1997). A democratic system of government, in part, depends on the public to advise the most appropriate course of action. Decisions are made "for the people by the people" and thus decisions are typically within the realm of what the status quo deems appropriate (Birkland, 2001).

Birkland (2001) describes the national mood as "how we feel about government, public problems, and the effectiveness of government and other institutions in successfully addressing these problems" (p. 200). The national mood is affected by factors such as levels of employment and overall economic conditions (Birkland, 2001; Citrin et al, 1997) as well as the influence of regional differences (Neal \& Bohon, 2003; Schmid, 2003; White, 1986).

\section{International Factor Influences}

"While in domestic society the good life can be discussed, the international domain has long been viewed as an anarchic, Hobbesian domain of mere survival" (Pieterse, 2002, p.1024).

The importance of the fourth type of public policy influence, international level factors, was noted from the formation of the League of Nations. The League of Nations encouraged a shift from national sovereignty to international agreement. Examples of international agreements are noted in documents such as the UN Declaration of Human Rights (1948) and later the Helsinki Accords (1975). Such documents increased the focus on international policy topics such as poverty, human rights, and migration.

At the international level of influence, ways to respond and encourage policy change include: economic intervention and/or sanctions, development of legal policies, and development of ethical policies (Morishipouri \& Welch, 2001). Examples of economic intervention on international policies include programs by the International Monetary Fund and the World Bank to supply underdeveloped and developing countries with much needed money to make change. For 
example economic sanctions were levied against South Africa during the time of apartheid to encourage the end of discrimination based on race. Assistance in the development of legal policies is noted through democratic governments helping developing and underdeveloped nations to design government systems. Development of ethical policies is portrayed through western intervention in developing and underdeveloped nations to aid in stopping practices such as genocide.

\section{Events as Factor Influences}

The fifth level of influence, events, centers on either the occurrence of a focusing event defined as a situation that brings the focus of individuals, interest groups, and/or nations to spotlight a particular topic (Birkland, 2001).

The level of impact by an individual event on the policy change is influenced by the factors of causality, severity, incidence, proximity, and crisis (Theodoulou \& Kofonis, 2004). Causality stems from determining where the responsibility for the crisis is derived. If the cause is more sensational, the status quo will push for a greater change. Severity centers on the level of pain or distress created by the specific event. A positive relationship is noted between severity and policy change. Incidence entails the frequency of the event. A repeat of a specific event creates a push for policy change. Proximity examines how close the event transpired to individuals and groups in power. Crisis is composed of the level of severity, proximity, and incidence. In conjunction with these five factors, official actors typically take into account the scope (percentage of people affected) and the monetary cost of policy change.

Public Policy Factors: Application to Immigration Specific Policy

The following section will apply the public policy influence factors of the individual, group, national, international, and event based to immigration specific policy.

\section{Individual Factors as Influences of Immigration Policy}

The application of individual factors to immigration policy is best described by a modern version of Robert Merton's Prejudice \& Discrimination typology (Pettigrew \& Meertens, 1995). This typology provides a way to understand how individuals view those that are different. Individuals are placed in one of four distinct categories: an error category ( $<2 \%$ of people), 
equalitarian, bigots, and subtles. Equalitarian individuals interact in non-prejudice ways, encourage high levels of interaction with immigrants, support immigrant rights, and discourage restrictive immigration policy. These individuals view the world with small levels of prejudice and see the need for immigration as humanitarian. Bigots interact in prejudiced and discriminatory ways, discourage interaction with immigrants, discourage immigrant rights, and encourage restrictive immigration policy. These individuals view the world with high levels of prejudice. Subtles treat others differently within the framework of what is acceptable in the status quo. A subtle might tell jokes making fun of specific groups of immigrants. The majority of the population would laugh and not think of the subtle as a "prejudiced person". Subtles view the world with moderate levels of prejudice. Viewing the world from four such different frames of reference create diverse ways of addressing public policy issues concerning immigration.

As suggested in the introduction, theories concerning individual attitudes toward immigrants are divided into the following categories: contact theories, in-group/out-group theories, and group threat theory. Contact theory declares that lack of intimate contact leads to higher levels of prejudice and discrimination (McLaren, 2003). In-group/out-group theory states that people naturally are more accepting of others considered part of his/her group. A correlation between out-group bias and prejudice is noted in the literature (Lee \& Ottati, 2002). A positive relationship exists between in-group cohesion and prejudice to immigrants (Zarate et al., 2002). Group threat theory asserts that the level of threat is determined by the size of the immigrant group and the economic condition (Quillian, 1995).

\section{Group Factors as Influences of Immigration Policy}

To examine some concrete examples of group factor influence on immigration policy, this section will use the United States policy from the 1880 s until 1924 as an example. Throughout United States history, influence groups have shaped policy decision making. The American Protective Association (APA) and the Know-Nothing Party placed pressure on our government, in the 1880 s, to decrease the number of Catholic immigrants entering the United States. The Progressive Movement, from 1900 to 1912 , attempted to rid the nation of any person against White Anglo Saxon Protestant (WASP) values. In the 1920s, the Klu Klux Klan (KKK) encouraged 
policies to decrease the numbers of immigrants admitted (Lipset, 1955). In addition, during this time period, the American Federation of Labor (AFL) encouraged more restrictive immigration policies due to a possible threat to working class Americans (Sanchez, 1997).

The influence of the preceding groups culminated in the Immigration Acts of 1917, 1921, and 1924 in which increasing restrictions were placed against immigrants not of WASP stock (Daniels, 2004).

\section{National Factors as Influences of Immigration Policy}

A link between national factors and immigration policy is noted by the connection between economic conditions and attitudes toward immigration policy (Citrin et al., 1997). As pessimism concerning the current economy increases, negative opinion of immigration policy also increases. In addition, a positive correlation is noted between level of restriction desired from policy and beliefs that immigration is harmful to employment in the host country. This link between the economy and attitudes toward immigration policy is compounded by the "differentness" of new immigrant groups, the media portrayal of immigration, and the opinions of political organizations and leaders (Rule, 1988).

The national view of citizenship influences immigration policy (Fassman \& Munz, 1995; Kurthen, 1995; Ludwig, 2001). A narrow view of citizenship is highly correlated with restrictive immigration policies while a more encompassing view of citizenship is highly correlated with an open immigration policy. Germany's difficult history of World War I, economic depression, and World War II has led to a shared destiny in what it truly means to be German (Kurthen, 1995). German citizenship is an example of the consensus type (jus sanguinis) due to the notion of citizenship based strictly having the same language, culture, traditions, and ethnicity. A child who has one German parent is considered a German citizen. Naturalization is only considered for individuals willing to assimilate to the German way of life, language, and culture. On the other side, the United States bases citizenship on the place of birth (jus soli). This type is derived from the United States as a country of migration in which citizenship was tied to residence in the new world.

International Factors as Influences of Immigration Policy 
External (international) events impinge on immigration policy to promote change in the following areas: socioeconomic conditions, public opinion, governing, and policy decisions concerning other subsystems (Birkland, 2001). Areas such as foreign policy, humanitarian aid, economic agreements, and armed conflict can impinge on policy decisions and various subsystems to create change.

The bulk of research at the international level centers on economic conditions and suggests that world level economic control is the basis of most national migration policies (Martin \& Straubhaar, 2002; Weiner \& Munz, 1997). Martin and Straubhaar (2002) explore a two part practice model that maximizes remittance payoffs and encourages migrants to return home to develop the economy in his/her native country. Under this plan, countries with higher levels of immigration explore policies that focus on trade, investment, and aid to reduce emigration out of developing and underdeveloped nations. Trade policies increase the competition of products and employment in the importexport business in both the host country and home country. Investment policies increase the funds, technology, and management to increase jobs in developing and underdeveloped nations. Aid helps in strengthening the economy in developing and underdeveloped nations, boosting employment, and increasing investment. Simultaneously, Martin and Straubhaar (2002) suggest using the three R's of recruitment, remittance, and returns in immigrant receiving countries to boost the economy and increase jobs. Recruitment involves actively seeking workers, as needed by the labor market of the host country, to fill open skilled and unskilled positions. Remittance involves migrants consuming goods and services in the host country; thus bolstering the local/state/regional economy. Returns are expected when temporary workers do not settle in the host country but return to his/her homeland as expected. Upon return, the migrant brings money back into his/her country to support the local economy abroad.

\section{Events as Influences of Immigration Policy}

An example of an event as an influence on immigration policy in the United States centers on the events of September 11, 2001. After this event, the following U.S. immigration policy changes were discussed: (a) creating a student and exchange visitor tracking program (H.R. 3205 \& S. 16168), (b) requiring background checks for all incoming students (H.R. 3239), 
(c) prohibiting student visas to students who are from a nation state suspected of terrorism (S. 1627), (d) placing a moratorium on the insurance of all visas to all nonimmigrant foreign students (H.R. 322), and (e) utilizing biometric techniques in the insurance of visas (S. 1518) (Theodoulou \& Kofinis, 2004).

Decisions were made to use U.S. immigration policy to detain, hold, and refuse the release of individuals strictly by the individuals' nation of origin due to fear of terrorism. The Department of Justice Inspector General (Glenn A. Fire) investigated this post 9-11 issue and found that within the 20 months after $9-11$, a total of 762 people were held and interrogated only to later be released (Daniels, 2004).

\section{Exploration of Proposed Model of Immigration Policy}

After the previous exploration of the factors influencing public policy and a specific application to immigration policy, it is now necessary to tease out the most relevant factors for proposing a new model for studying immigration policy. A new immigration model needs to provide an integrated template for exploring: a) the individual policy level, b) the policy change over time within a country, and c) the policy change over time between countries. The proposed model of immigration policy provides a template that helps to examine immigration policy at all three needed levels.

The Cappiccie Lawson Evolution of Immigration Model (CLEIM) (see Figure 1.) begins with the triggering of a focusing event that transpires to bring attention to the specific incidence (Birkland, 2001). Instead of an acute event, an event might also be defined as a compilation of pressures that combine to culminate in forces similar to that experienced in a culminating event to trigger policy change. An actual event may be internal or external in nature. An internal event occurs within the confines of an organized structure (i.e. local, state, region, nation, and international). An external event exists outside of what is considered part of an organized structure. Determining whether an event is internal or external depends on the current status quo picture of what is internal or external in nature.

The event (whether internal or external) is impinged upon by the factors of causality, severity, incidence, proximity, and crisis. A positive correlation is noted between these factors and 
the push for policy change by the status quo. These impinging factors thus shape the perception of the event (Theodoulou \& Kofinis, 2004). Causality stems from determining where the responsibility for the crisis is derived. If the cause is more sensational, the status quo will push for a greater change. Severity centers on the level of pain or distress created by the specific event. A positive relationship is noted between severity and policy change. Incidence entails the frequency of the event. A repeat of a specific event creates a push for policy change. Proximity examines how close the event transpired to individuals and groups in power. Crisis is composed of the level of severity, proximity, and incidence. In conjunction with these five factors, official actors typically take into account the scope (percentage of people affected) and the monetary cost of policy change (Theodoulou \& Kofinis, 2004).

The event, as portrayed through the filter of the previous factors, influences the international situation, the national situation, influence groups, and policy changers. With the increase of globalization, events in one country increasingly concern other countries. International level factors to examine include: foreign policy, human rights policy, humanitarian aid decisions, economic agreements, and conflicts. As the magnitude of an event increases, the likelihood of international effects also increases.

Naturally, a focusing event impinges upon the country where the incidence occurs. National factors such as government structure, economic situation, employment, country view of citizenship, regional differences within country, and in-group versus out-group phenomena respond to the event. Depending on the view of the status quo through the complex combination of factors, the event impact may be large or small. In addition, the impact of an event can increase or decrease over time. An example of this phenomenon is noted in the story of the Laramie project in which a young gay male, Matthew Shepherd, was brutally beaten and left to die by two local males. At first, this horrific event influenced only the surrounding area where the incident transpired. When national activist groups helped to write the story of Matthew for a movie portrayal and play adaptation, the event raised the consciousness of a nation. This example also helps to understand the impact of influence group response to a particular event. 
An influence group can assist in raising the consciousness of the status quo thus encouraging change or the influence group can attempt to encourage change at the policy changer level. Influence groups use different tactics to help focus attention on a specific topic such as rallies, sit-ins, media interviews, media campaigns, flyers, local meetings, etcetera. The underlying attempt of all tactics is to make change in policy centering on the influence group's mission.

The interchange between an event and the international and or national situation is bidirectional. As such, the international situation and the national situation can either be influenced by a trigger event or can act as an antecedent to a trigger event. Elements of the national and international situation such as history, governmental changes, public policy changes, regional differences, past humanitarian efforts, and international agreements can act as antecedents to create pressure that helps encourage multiple small events to transition to the level of a trigger event; thus influencing immigration policy change. Remember that true antecedents to events are culture dependent. The collective meanings of a specific culture guide whether a unique combination of antecedents result in a push to a trigger event or rather stay as guiding factors as only an element within the national and/or international situation. An example of national antecedents placing pressure to form a trigger event is the anti-Asian sentiment leading up to the Chinese Exclusion Act of 1882 in the United States. The following are applicable antecedents: yellow peril newspaper articles, discriminatory housing and marriage laws, the use of Asian strikebreakers, anecdotal data of Asians taking American jobs, and the increasing numbers of Asians all acting as a push to create a trigger event that resulting in restrictive Asian immigration policy.

An event influences the official actors, called policy changers for this model, to vote for policy change in one of three directions: a) no change, b) restrictive change, or c) less restrictive change.

The international situation, national situation, influence groups, and the policy changers can also affect the other factors through the influence of communication, media, information, international agreements, etcetera. The policy changers can encourage influence groups to 
accept small change toward their cause rather than the drastic change originally planned. Policy changes within one country can exert influence upon other countries to create change. For example, a United States policy changer might support humanitarian aide to Rwanda and Somalia; thus changing the international situation within that part of Africa. The influence group can raise the consciousness of the status quo (as noted in the example of Matthew). A national situation (i.e. large numbers of migrants) can create the need to explore the effect of a phenomenon in other countries; thus examining the need for international agreements to influence change on a specific topic. Influence groups can encourage other nations to rise to a similar level of change to promote a particular cause. Human rights activists in Germany might demonstrate against alleged human rights abuses in Guantanamo Bay and as a result activists in Western Europe and the United States push for change in United States policy.

Patterns of change in immigration policy can be plotted along the continuum as you compare policy change over a particular time period. In order to perform this examination, the Cappiccie Lawson Evolution of Immigration Model is applied to each policy within a specific time frame. This application can be applied policy by policy within a selected country. In addition, this application can be applied cross culturally to examine whether national level events similarly influence policy change in various countries.

The impact of the event on the international situation, the national situation, the influence group, and the policy changers combine to determine policy change. An immigration policy change decision can be placed on a continuum from exclusion to inclusion. This part of the Cappiccie Lawson Evolution of Immigration Model will be referred to as the Policy Response Continuum. It is a visual representation to explore where a specific immigration policy falls between the polls of inclusion and exclusion.

\section{Realm of Policy Responses}

To understand this response continuum, we will examine the topics of inclusion and exclusion to ensure a basic understanding of these terms.

The Topic of Inclusion 
Inclusion is defined by the Merriam Webster Online dictionary as the act of including or the state of being included. Include is defined as to take in or comprise as part of a whole. Immigration policies that are inclusion oriented allow immigrants to enter the host country. Literature suggests that reasons for inclusionary policies are based on altruism or need for workers (Carens, 1996; Daniels, 2004; Kurthen, 1995; Noddings, 2002).

\section{Altruism.}

Carens (1996) asserts that international migration policy is based on the belief in the responsibility each country has to care for others throughout the world. This caring led to the idea of human rights as portrayed in international documents such as the UN Declaration on Human Rights (1948) and the Helsinki Accords (1975). Through such documents, individuals throughout the world have certain human rights guaranteed. One of which is the human right to migrate. A vibrant example of the true meaning of altruism is portrayed in the saying on the statue of liberty by Emma Lazarus (1883): "Give me your tired, your poor. Your huddled masses yearning to breathe free. The wretched refuse of your teeming shore. Send these, the homeless, tempesttost to me. I lift my lamp beside the golden door!"

The theme of altruism is noted throughout many world religions. The golden rule, associated with the Christian religion, "treat others as you want to be treated" is the foundation of a spirit rooted in altruism. Noddings (2002) explores the basis for the giving spirit and contends that our willingness to give to others stems from the need in humans for care and attention. Since we desire care and attention from others we understand, in our being, that it is the same for others.

Need of workers.

Daniels (2004) provides two different programs in United States history as examples of the inclusion of workers to fill needed work positions. During World War I, the United States actively recruited Mexican workers from May 23, 1917 until March 1921 to fill unfilled positions on farms, railroads, mines, and manufacturing. Positions were absent due to males going to war during that time period. Again during World War II, the United States implemented the Bracero Program to actively recruit Mexican workers from July 1942 until the mid 1960s. Workers were 
initially sought to fill open jobs in the farming community. A separate program was started to specifically bring 50,000 Mexican workers to the western railroad companies. Sanchez (1997) asserts Pete Wilson assisted in securing an exemption for undocumented California workers in the mid-1980s.

In a similar fashion, Germany brought guest workers (gastarbeiters) to work between 1960 and 1973 to fill open jobs on a 1 to 3 year rotation system (Kurthen, 1995).

\section{Exclusion: Fear and Group Threat Theory}

Exclusion is defined by the Merriam Webster Online dictionary as the state of being excluded. Excluded is defined as to prevent or restrict the entrance of or to bar from participation, consideration, or inclusion. Literature on exclusionary policies examines the theory of how fear of outsiders creates a restrictive mindset (Blumer, 1958; Quillian, 1995).

Examples of fear response are noted through U.S. immigration policy literature (Daniels, 2004; Lipset, 1955; Sanchez, 1997). During the Depression of the 1930s, William Boak (Herbert Hoover's labor secretary) promised to deport illegal immigrants in order to scapegoat this segment of the population as the root cause of the stock market crash (Sanchez, 1997). From 1930 to approximately 1945 the values of conservatives were attacked due to a struggle against Communism and Fascism reaching its peak in McCarthyism and Japanese relocation camps (Lipset, 1955). The changes post 9-11 have been previously discussed in this paper as a response to fear (Daniels, 2004).

\section{Pressures on Response Continuum}

When referring to humanitarianism, Vaux (2001, p.201) states:

Humanitarianism is the ideology of hegemonic states in the era of globalization marked by the end of the Cold War and a growing North and South divide. It mobilizes a range of meanings and practices to establish and sustain global relations of domination. In particular, it manipulates the language of human rights to legitimize a dubious range of practices, including its selective defense.

Vaux (2001) asserts that, since World War II, the term humanitarianism entails subjective changes in political thought. These changes over time are partially due to the active role in the 
media shaping how a nation feels about helping "the other". Changes have led to a cycle in which western societies pick and choose humanitarian efforts based on factors, other than need, such as greed, sloth, anger, covetousness, lust, envy, and pride (Vaux, 2001). Greed involves higher levels of competition and efficiency leading to a survival of the fittest ideology in which some countries obtain more while others obtain less. Sloth creates a negative view of poverty stricken cultures as lazy in comparison to developed countries; thus somehow deserving a life of poverty. Negative beliefs toward developing and underdeveloped nations leads to increasing border restrictions to outsiders. Covetousness encourages high levels of competition for government funds; thus in reality decreasing funds to the most needy. Lust creates decreased media attention on the realities of poor countries. A concrete example is found in the changes of media attention from the end of the Cold War era until present day. Research suggests that in Cold War times the majority of media attention focused on public information while current programming is focused on entertainment. Envy stresses that altruism is a form of selfishness. Pride can lead to selfishness in what policy topics are important instead of focusing on what is best for the populace as a whole or the international community as a whole. Vaux (2001) suggests that all individuals and nations have the ability to choose between policy that is selfish by nature or truly altruistic.

As altruism decreases in social policy, power increases (Noddings, 2002). Furthermore, altruism is replaced with a paternalistic response from the wealthy countries to the developing and underdeveloped countries. A shift of power back to the individual and away from the collective might help to bring back altruism as the base of social policy. Individually influenced policies encourage a shift of care based on listening to the need of people rather than political forces (Noddings, 2002).

\section{Policy Response Continuum}

A specific policy response is placed along the Policy Response Continuum from inclusive to exclusive. The details of the specific policy are a guide to assist the researcher in deciding the exact placement along the continuum. Timmer and Williamson's (1998, p.741) index of immigration will be used to consider placement of policy along a continuum from inclusive to 
exclusive. If a specific policy has details from more than one section, the two are added together to find the number that will be used to determine where this policy is placed along the continuum (i.e. $5+-(3)=2)($ See Table 1.)

Ways to Examine the CLEIM Model as Applied to Individual Policy

To establish a standard for examination of the model factors proposed to affect policy change, both for policy specific and cross cultural comparisons, the following "data" may be used for each policy discussed: events through history books and expert portrayal; international situation through history books and expert portrayal; national situation through history books and expert portrayal; influence groups through popular media (i.e. newspapers, magazines, advertisements, television) and expert portrayal; policy changers through voting history, subcommittee ideas for change, expert portrayal; and policy change through policy details, latent and manifest consequences of policy change (as reported by experts).

Application for United States, Germany, and Russia

This chapter provided a review of the literature surrounding the factors that influence the formation and implementation of public policy. Factors include: international factors, national factors, influence groups, policy makers, and events. These factors were applied to immigration specific policy. With the knowledge gleaned from the literature review, a model of immigration policy was proposed. This model includes both the Cappiccie Lawson Evolution of Immigration Model (CLEIM) and a component called the Policy Response Continuum which aides in viewing the policy on an inclusion versus exclusion basis.

Chapters II- IV will apply CLEIM to the United States, Germany, and Russia. The model will be applied to each immigration policy within the studied country's immigration policy history. Policy examination of the United States will begin in 1882 with the Chinese Exclusion Act. Policy examination in Germany will begin post World War II (late 1950s). Policy examination in Russia will begin after the end of Communism (early 1990s). 


\section{CHAPTER II}

\section{APPLICATION OF CAPPICCIE LAWSON EVOLUTION IMMIGRATION POLICY MODEL TO UNITED STATES POLICY}

"Immigration is a labor flow that should be meshed with the changing needs of the national economy, and the demographic nation-shaper that should be harnessed to national population goals." (Graham, 2004, p.95).

United States Immigration Policy Perspectives

United States immigration policy perspectives are fragmented into dichotomous viewpoints: the pro-immigration and anti-immigration views (Theodoulou \& Kofinis, 2004). Proimmigration proponents report the importance of increased immigration numbers to strengthen the national historical/cultural value and the short and long-term economic benefits. In addition, proponents emphasize the exaggerated costs of immigration inappropriately emphasized by politicians and the media. Anti-immigration supporters emphasize the following problems created by immigration: social and economic difficulties, past policy failure, need for stronger internal and external controls, and the security risk. Perhaps as these two different views suggest, United States immigration policy is in actuality ambiguous in nature as exhibited by images such as Lady Liberty and her "huddled masses" on one side and the media portrayals of immigrants flooding the border on the other (Hernandez, 1999).

Tichenor (2002) provides a two dimensional model to explore beliefs centering on admissions and rights of immigrants in the United States (See Table 2.) The two main categories of this table are rights and admissions. Admissions entail two categories: expanded/maintained and restricted admissions. Rights toward immigrants entail two categories: expansive or restrictive rights. A list of individuals throughout history and his/her beliefs concerning admissions 
and rights are provided to help readers understand the diverse beliefs of the United States populace throughout the history of immigration policy.

\section{Positive and Negative Aspects of Immigration}

The polarized belief system associated with United States immigration is further enforced by literature that provides a portrait of both the positive and negative effects of large numbers of migrants (Graham, 2004). Positive aspects of immigration in the literature include: employees for open jobs, changes in cuisine, the growth of specific industries (i.e. wine, tobacco, poultry), and the creative immigrant talent that has moved to America (i.e. LaGuardia, Sinatra, Gershwin). Negative aspects of immigration in the literature include: wage depression, urban crowding, disease, illiteracy, cultural resistance to progressive change, and the evolution of crime syndicates (i.e. McKinley's assassin Czolgosz, Al Capone, Lucky Luciano, etcetera.).

\section{United States Policy Goals}

United States immigration policy has historically attempted to address the following goals: (a) social integration, (b) economic issues, (c) moral issues, (d) cultural changes, (e) and national/economic security issues (Theodoulou \& Kofinis, 2004). At different times in history, United States' policy has placed more importance on some of these goals than others.

Espenshade et al. (1997) adds the goal of controlling the number of migrants through introducing strict enforcement of internal and external controls. Internal controls are restrictions placed within the country to limit access to the needs of migrants; thus decreasing the pull factors to enter the country. Examples of internal controls of immigration are decreasing access to jobs (i.e. paperwork for employment, employer sanctions for hiring undocumented) and social services. External controls are restrictions in order to stop entrance into the host country (i.e. border patrol, visas, passports). It is important to remember that policy goals and actual policy implementation are not parallel; policy does not always implement in the ways that the policy was intended. As a result unintended consequences are produced (Espenshade et al, 1997).

Policy goals are uniquely implemented, in the United States, due to the past history of "republicanism" (Graham, 2004, p.20). The U.S. idea of citizenship spotlights the concept of individual strength. Individual strength was rewarded and demanded as a necessary 
characteristic to break from mother England. For new independence to succeed, concepts of "civic virtue" such as voting and public affairs were paramount. As large numbers of immigrants arrived on the United State's shores, citizens worried about long term consequences impinging on the ideas that founded the United States. Treatment of new immigrants focused on the similarities or differences of the new arrivals. Acceptance of immigrants considered similar was expedited due to the United States involvement in the Civil War and Spanish-American War. New immigrants willing to support the nation's causes were deemed acceptable. Immigrants arriving later did not fair as well. A reception of ambivalence and anger was in part attributed to a fear reaction of how the core American values would be changed by the increasing numbers.

\section{Goals of Chapter}

This chapter will provide an overview of the periods of immigration and immigration policy throughout the history of the United States. After exploring the basics of policy history, an analysis of the most pertinent immigration policies from 1882 to 2002 will be performed by applying the Cappiccie Lawson Evolution Immigration Model (See Figure 1.) to each specific immigration policy. The application of CLEIM to each U.S. policy will begin to answer the research question pertaining to the accuracy of the model $(\# 5)$, the role of influence groups $(\# 1)$, the role of policy changers (\#2), the role of events (\#3), and the use of applying the Policy Response Continuum (\#6). If an important historical event occurred between the discussed immigration policies, this information will be provided in sections of the chapter marked as "Historical Context between Immigration Policies". The historical underpinning between policies continues to be important in understanding the changes over time. To summarize current policy shifts, a short exploration of the current and future needs of United States policy will be discussed.

\section{A Basic Overview of United States Immigration Policy}

"Throughout its history, the United States has acted independently concerning decisions involving immigration. The overarching policy often has been what is perceived to benefit the U.S. at a particular moment." (Churgin, 1996, p.310) 
A fallacy exists that United States immigration policy has throughout history focused on the positive aspects for both society and the individual immigrant. In fact, immigration has focused on the cost and benefit to the country, with little regard to the individual immigrant. This cost/benefit focus has progressively changed from minimum federal regulation to high levels of federal regulation requiring specific preferences for migrants (Graham, 2004).

The following overview of the United States policy will explore the following periods of immigration shifts: from 1565-1776, 1777-1875, 1875-1965, 1965-2001, and 2001 to present.

Immigration: The Beginnings until 1776

From 1565 until 1630, the territory west of Europe, later called the United States of America, experienced many migration firsts. In 1565, the first documented Spanish missionaries traveled to St. Augustine. The first official Spanish settlement was founded in New Mexico in 1598. Soon after, the first English settlement was founded in Jamestown in 1607. The first slave ship carrying Africans forced to migrate to America docked in Virginia in 1619. In 1620, the Pilgrims arrived in Massachusetts (DeSipio \& Garza, 1998).

After settlements were formed, other individuals wanted to migrate to the new land in the West. From 1630 to 1776 , approximately 600,000 settlers arrived on the shores of America (DeSipio \& Garza, 1998). Of this total number, $90 \%$ were English with the other $10 \%$ Africans forced into "involuntary immigration" as slave labor to Southern plantations (p.22). This ratio of white migrants to Africans of "involuntary immigration" changed in the time period of 1713-1776. Approximately 350,000 migrated with $60 \%$ deriving from England, Ireland, Germany, Scotland, and the Netherlands and as much as $40 \%$ Africans of "involuntary immigration" (p.22).

Immigrants, not forced to migrate, arrived on his/her own resourcefulness, as indentured servants or convicts (DeSipio \& Garza, 1998). Indentured servitude was an early form of labor recruitment that would continue into the $21^{\text {st }}$ century. The largest portion of indentured servants arrived in the middle and Southern colonies leaving the New England area mostly free, white English and Welsh; the New York City area Dutch; the Philadelphia and East Pennsylvania area German, the Chesapeake Bay area convicts, and the South with mostly African, German, Scottish, and Scots-Irish (DeSipio \& Garza, 1998). 
Not included in the early numbers of migrants were the Spanish settling in Florida and the South West as well as the French colony in Louisiana. This is perchance due to those territories of the new land not yet being considered part of America (DeSipio \& Garza, 1998).

Pre-Revolution attitudes toward immigrants centered mainly on wanting to find hard workers that were willing to perform backbreaking duties for little pay. However, this generous attitude did not include all types of immigrants. Negative attitudes toward those considered "different" created localized problems which resulted in early attempts to restrict migration (DeSipio \& Garza, 1998). In 1751, Benjamin Franklin published a work entitled "Observations Concerning the Increase of Mankind" (Daniels, 2004, p.8). This work focused on the differences of new migrants, especially targeted toward the German settlers in Pennsylvania, as possessing negative habits and, as such, unable to assimilate.

Restrictive attitudes soon dissipated as America was focused on the prelude to the Revolutionary War from 1763 to 1775 and the official Revolutionary War from 1775 to 1776 (DeSipio \& Garza, 1998).

\section{Formation of the Government}

After the Revolutionary War, immigration was again a secondary topic as the nation focused on the writing of the Constitution (Birkland, 2001). The Constitution established the formal government for the United States of America. The Republic form of government has three distinct branches: the executive, the judicial, and the legislative. The branches are responsible for the following: the executive is responsible for executing the laws, the judicial is responsible for interpreting the laws, and the legislative is responsible for making the laws. The executive is composed of the elected president and his cabinet (appointed by the president). The judicial branch is composed of federal judges and the Supreme Court. The legislative branch is composed of two houses of government: the House and the Senate. The house is composed of state representatives elected by the people of a particular state. The number of representatives from each state is determined by the population of the state. The Senate is composed of two senators from each state elected again by the people of a particular state. The three branches of government work together in a system of "checks and balances" to ensure that the government is 
being run properly without excessive control by any of the three branches. This system allows each branch some power on its own accord and also some power to regulate the other two branches (Birkland, 2001).

State governments are organized in a similar manner as the federal government. The head of the state executive branch is the state's elected governor. Some topics are relegated to the Federal level of decision making while others are considered states concerns. Through the years, the judicial branch has helped define topics that are overseen by the federal or state level (Birkland, 2001).

The Constitution does address immigration, albeit vaguely. Article I, Section 8 provides for naturalization of immigrants. In addition, a naturalized immigrant is able to hold all offices other than the President and Vice-President. This was the sum total of the guidance provided by our forefathers on immigration and naturalization (Daniels, 2004).

Attitudes toward Migrants

A picture of attitudes towards immigration during the Colonial period can be teased out by examining writings of well-known national leaders (DeSipio \& Garza, 1998). Thomas Jefferson expressed concerns centering on the assimilation difficulties of immigrants not of "white European heritage" (p.25). During Jefferson's life, the dominant political party, the Federalist Party, envisioned immigration as a way to increased numbers of people to manipulate into voting against the Jeffersonian Party (Democratic Republicans). These attempts to raise numbers slowed during the French Revolution for the French were believed to hold an ideology that could upset the voting balance.

Increasing fear, of immigration numbers, led to the passage of the Alien and Sedition Act (1798) in an attempt to regulate immigration and control whom to grant naturalization. John Adams was President (1797-1801) during this time period and it is believed that his personal beliefs concerning whom to admit were incorporated into this first immigration policy. The focus on naturalization policy decreased with the election of the next United States president, Thomas Jefferson, in 1801 (DeSipio \& Garza, 1998).

Immigration: 1777-1875 
From 1777-1875, minimal federal regulation existed in immigration policy; rather states separately enforced migration (Theodoulou \& Kofinis, 2004). The little policy available for guidance focused on the transportation of immigrants (DeSipio \& Garza, 1998). According to an 1819 law, shipping companies had to provide a list of all non-citizens on board to the harbor master. Specific ships not in compliance could be found liable through hefty fines (Churgin, 1996).

The first large wave of immigrants arrived from 1820 until the late 1850 s with numbers reaching approximately 120,000 immigrants per year to ultimately total over three million immigrants (Churgin, 1996). The majority of the three million emigrated from England, Ireland and the North and West of Germany. Immigrants from Northern and Western Europe were similar to United States' citizens in appearance, beliefs, and religion. The term White Anglo Saxon Protestants (WASPs) is used to describe people from Northern and Western Europe. This first influx of immigrants slowed during the period of the Civil War (1861-1865) when the United States was focused on its own ideological and economic differences (Churgin, 1996).

Immigration: 1875-1965

The end of the Civil War marked an increase in migration to the United States. As a result, the Supreme Court declared that immigration issues were mandated by federal jurisdiction (Theodoulou \& Kofinis, 2004). Shortly thereafter, the large influx of immigrants, known as the second wave of immigration, arrived from 1880 until 1930 with numbers totaling approximately 27 million. The majority of the second wave emigrated from Southern and Eastern Europe. This new group of immigrants was quite unlike the first wave of immigrants in appearance, culture, behavior, and religion (Graham, 2004). Fear and worry concerning the newly arrived migrants and the "differences" in appearance and culture influenced restrictive changes in immigration policy culminating in a policy denying entrance based on national origin in 1882 (DeSipio \& Garza, 1998).

Although this time period is known for increasing restriction, specific groups did attempt to help the immigration population. Early attempts to help immigrants included: the settlement house movement, charity organizations, churches, YMCA, patriotic societies, employers and 
business leaders, unions, and a variety of General Federation of Women's Clubs (Graham, 2004). Organizations approached assimilation of immigrants in one of two ways: acceptance and anxiety/coercion. In an acceptance centered organization, new immigrants were welcomed as providing society with special gifts. To help with the transition, immigrants could attend classes to learn the language, customs, and habits of American culture. Anxiety and coercion organizations attempted immediate change to the American way of life through total immersion in classes of English, citizenship, and hygiene mostly implemented through the use of the existing school system (Graham, 2004).

\section{Immigration: 1965-2001}

From 1965-2001, immigration policy attempted to stop the policy focus of restriction based on national origin. Instead, the new policy agenda focused on allowing select groups of immigrants to enter the United States. Select groups included the following types: employment, family reunification, diversity, and lottery. Throughout this time period, changes in policy progressively attempted to determine the most appropriate mechanism for lowering numbers of undocumented immigrants (DeSipio \& Garza, 1998).

\section{Immigration: 2001-Present}

United States immigration policy from 2001 to the present has focused on ways to reduce migration through strict enforcement of internal and external controls as a means to ensure homeland security (Theodoulou \& Kofonis, 2004).

\section{Specific Immigration Policy Analysis and Application of CLEIM}

The next section of this paper applies CLEIM to United States specific immigration policy from 1882-present. As the model is applied, note the role of specific CLEIM policy elements: events, influence groups, policy changers, national/international situations, and the application of the policy response continuum. If specific unintended consequences developed as a result of the policy, these costs will be noted and discussed.

The Chinese Exclusion Act of 1882 
"The real tragedy is not that the United States restricted immigration, but that it did so in a blatantly racist way that perpetuated old injustices and created new ones, which endured for decades". (Danie/s, 2004, p.56)

The application of CLEIM to the Chinese Exclusion Act will explore the policy basics and then apply model elements to this specific policy. The official title of the Chinese Exclusion Act is "To Execute Certain Treaty Stipulations Relating to the Chinese" (Daniels, 2004, p.19). This act prohibited Chinese migration (both skilled and unskilled) after August 4, 1882. Chinese present from November 17, 1880 until August 4, 1882 could freely migrate between China and the United States. Fines of up to $\$ 1000$ per person could be applied for illegally transporting a Chinese person into the United States. Chinese diplomats were able to come for short periods of time for business purposes only. A loophole was noted that allowed for Chinese to travel to the United States from a third country. This loophole was stopped by an amendment to the act in 1884 to ensure exclusion of all Chinese. For other ethnicities of immigrants, a head tax or entrance fee was instituted of $\$ .50$ per person (Daniels, 2004).

International Situation

Throughout the world, colonization continued in which world powers dominated over underdeveloped nations. Examples in 1882 include: the Boers establishing the Republic of Stellaland in Southern Africa and British troops occupying Cairo, Egypt to become the protectorate of this country (Wikipedia, 2006).

In China, the Chinese Civil War, known as the Taiping Rebellion, lasted from 1851-1864. Due to the strife of war and the resulting economic depression, many individuals emigrated from China to places where it was believed he/she would be free from the stressors of rebellion. The United States drew many Chinese immigrants during this time period due to the lure of the gold rush. The idea was to make money quickly and then return home to China (sojourners). In 1869, the pull factors shifted from gold to jobs for the Union-Central Pacific Railroad. Over 10,000 Chinese workers helped lay the railroad track from California to Promontory Point, Utah (Daniels, 2004).

National Situation 
United States policy since 1880 has focused on the restriction of individuals based on national origin (Bean et. al, 1990). The first focus of this was noted in the Burlingame Treaty (1880) which allowed for restriction of immigration to laborers, as determined by the federal government (Churgin, 1996). This restriction greatly affected the Chinese since the majority of laborers from 1850 on were of Chinese descent (Daniels, 2004).

The United States set up a second processing center, similar to Ellis Island, known as Angel Island to process the increasing number of arrivals on the West coast. Angel Island had a rejection rate of $18 \%$ compared to $1 \%$ at Ellis Island (Daniels, 2004). Furthermore, the west coast required more thorough verbal and physical examinations. Angel Island immigrants were mandated to spend the night, unlike Ellis Island where processing was typically closer to $1 / 2$ day or less. Daniels (2004) suggests the difference in processing was "to isolate and to impede the immigration of the Chinese" (p.25).

\section{Influence Groups}

As the Chinese entered the United States, individuals typically lived in ethnic enclaves within larger cities of California (Graham, 2004). The separateness of the Chinese was viewed negatively by the dominate group; contributing to the development of the California Working Man's Party. This party attempted to restrict Chinese settlement through passage of local policies such as anti-miscegenation laws and discriminatory land ownership laws. Anti-Chinese sentiment moved to the East coast when Chinese immigrants were used as strike breakers in large cities in the Northeast (Graham, 2004).

The 1840 s bestowed an increase in protestant nativist groups throughout the nation (Daniels, 2004). These groups were vocal and in favor of restriction against any immigrant group deemed different than the dominate group. Anti-Catholic riots occurred throughout the country including an incident known as Bloody Monday in Louisville, Kentucky. During this incident, a row of immigrant tenement houses were set on fire and the entrances blocked with the intent to burn the undesired alive.

In 1850, the organization known as the Know Nothings formed (Daniels, 2004). In reality, the Know Nothings was a secret protestant police organization called the Order of the Star 
Spangled Banner. For the upcoming 1856 election, the Know Nothing party formed an official political party to run a presidential candidate on an anti-immigrant platform.

Henry George, a well-known writer, published untrue newspaper stories centering on the invasion of the United States Army by Chinese immigrants (Daniels, 2004). These newspaper articles started what is commonly called the "yellow peril". Other sensationalized newspaper articles followed proclaiming untruths about Chinese migrant workers. The belief of the American public in the truth of such articles was epitomized in Ulysses S. Grant's State of the Union address in 1874 which focused on illegal Chinese laborers and Chinese females brought to the U.S. for immoral reasons. Grant called for legislation to address this growing problem that he believed to be of utmost important through the claims by the respected media (Daniels, 2004). Policy Changers

The Presidential elections of $1884,1888,1892$, and 1896 involved immigration as a topic of the candidates' platforms (Graham, 2004). In 1884, Democrat Grover Cleveland defeated Republican James G. Blaine. In 1888, Incumbent Grover Cleveland wins the popular vote but loses the Electoral College and thus Benjamin Harrison assumed the Presidency. In 1892, Grover Cleveland defeated Benjamin Harrison to serve as the President for a second non-consecutive term. In 1896, William McKinley defeated William Jennings Bryant (Wikipedia, 2006). Inclusion vs. Exclusion Level

The Policy Response Continuum as applied to the Chinese Exclusion Act provides an example of a level negative one policy. Negative one level policy provides class restrictions on immigration or selective sources of entry. The Chinese Exclusion Act is an example of a selective source of entry due to denying Chinese access to the country with rare exception (Timmer \& Williamson, 1998) (See Table 1.)

\section{Policy Change Consequences}

The Chinese Exclusion Act (1882) is perceived to symbolize the beginning of immigration policy restriction in the United States (Daniels, 2004). This policy was the precursor to 39 years of increasing levels of exclusion based on national origin (1882-1921) followed by 22 years (19211943) of increasing levels of restricted numbers based on political purposes. 
Underlying reasons for the restrictions in this act are concentrated into three distinct areas: economic, political, and social explanations (Timmer \& Williamson, 1998). Economic explanations center on the competition of jobs between California natives and the newly arrived immigrants. As the perceived threat to native job security increased, pressure was placed on policy changers to restrict immigrant workers. Political explanations center on fear of naturalization leading to increased voting power of the working poor. If large numbers of immigrants move to the United States and become naturalized, voting power will increase ensuring immigrants the right to make change through the power of the vote. Social reasons center on the large cultural gap between natives and Chinese. This gap led to high levels of racism and fear exhibited by racial slurs, segregation, anti-misogynous laws, and encouragement for land ownership changes.

Consequences of Chinese exclusion act: Legal cases.

After the passage of the Chinese Exclusion Act, several court cases were brought against the United States (Churgin, 1996). In Chae Chan Ping versus United States (1889), the ability to exclude Chinese immigrants was upheld by the Supreme Court. In Fong Yue Ting versus United States (1893), the Supreme Court found that the nation can deport, expel, or prohibit the entrance of any immigrant to the country. In addition, it was determined that the due process of the $5^{\text {th }}$ Amendment does not apply to non-citizens.

Consequences of Chinese exclusion act: Changes.

The Chinese Exclusion Act was expanded to include other types of Asians through the passage of later policies. The Japanese were restricted by the Gentlemen's Agreement (1907) and all Asians were restricted by the Immigration Act of 1917 with the implementation of the Asiatic bar zone (Theodoulou \& Kofinis, 2004).

Consequences of Chinese exclusion act: unintended.

One unintended consequence of the Chinese Exclusion Act was the establishment of mutilated marriages. The Chinese male that could travel back and forth between the United States and China would visit his young female bride in China. Many times the female would become pregnant. The resulting child was considered a United States citizen and could join the 
father in the United States. The mother could not join the family and thus the family unit was unable to live together. This disconnect created adjustment difficulties for those of Chinese ancestry for generations.

\section{Historical Context between United States Immigration Policies}

Between the Chinese Exclusion Act (1883) and the Gentlemen's Agreement (1906), the following changes transpired: the belief associated with the symbol of the Statue of Liberty changed, immigrant living conditions worsened, immigrants attempted to gain power, and the first immigration service was formed.

The year 1903 marked the date of Emma Lazarus' plaque being placed on the Statue of Liberty with the following poem: "Give me your tired, your poor, your huddled masses yearning to breathe free, the wretched refuse of your teeming shore. Send these, the homeless, tempest-tost to me; I lift my lamp beside the golden door!" (Graham, 2004, p.101). The Statue of Liberty, previous to 1903 , symbolized the idea of freedom. With the placement of Lazarus' plaque the symbol shifted from a meaning centered on freedom to acceptance of immigrants (Graham, 2004). While the Statue of Liberty proclaimed freedom for all, the beliefs of the status quo attempted to block the numbers of migrants arriving at the country's shores. Incongruence between Statue of Liberty and Attitudes

The incongruence between the symbol of the Statue of Liberty and the reality of status quo attitudes is noted as early as the late $19^{\text {th }}$ Century. In the Northeast, the 1890 s noted a correlation between high unemployment, high demographic change, and negative attitudes toward migration. The south continued to view migration negatively even after employment returned to high levels. In the mid-west, a pro-migration attitude existed until after World War I (Timmer \& Williamson, 1998).

Anti-immigrant sentiment led to the rise of the Immigration Restriction League (IRL) was founded in Boston during 1894. The IRL was established by three Harvard graduates: Prescott Hall, Robert Ward, and Charles Warren. This influential group is considered to be the beginning of right wing think tanks (Graham, 2004). The founders drafted letters to send to governors asking questions about what each individual perceived as an acceptable level of migration. Of the letters 
sent, twenty-six governors responded with the following results: eight wanted to stop immigration and 18 wanted only WASP immigrants. Henry Cabot Lodge (a representative for the state of Massachusetts) was an avid supporter and member of the IRL (Daniels, 2004). The IRL continued to support reduction in non-WASP immigrants and literacy tests until World War I (Daniels, 2004).

\section{Immigrant Living Conditions}

As the negative attitudes increased, life in U.S. cities continued to deteriorate for the nation's immigrants. Life in U.S. cities for immigrants consisted of tenement housing with little space, high crime rates, numerous contagious diseases, and the formation of segregation through ethnic enclaves (DeSipio \& Garza, 1998). Little assimilation occurred either linguistically or geographically. Formal education for children typically lasted only 4 years so that a new labor force could start work more quickly. Both women and children worked long, difficult hours along with their male counterparts. Jobs supplied low pay and dangerous working conditions. These poor conditions worsened as the numbers of migrants increased (DeSipio \& Garza, 1998).

\section{Power for Immigrants}

Urban political machines started after the Civil war and gained clout during the late $19^{\text {th }}$ and early $20^{\text {th }}$ century in Northeastern cities (DeSipio \& Garza, 1998). These "machines" were controlled by first and second generation immigrants and provided political power to new immigrants. In addition, political machines provided unofficial social welfare help to political supporters such as making jobs available to new immigrants, providing food supplies, mediating between immigrants and non-immigrants in disputes, assisting with naturalization, and assisting in voting registration.

\section{The First Bureau of Immigration}

The first official Bureau of Immigration was established on July 12, 1891 and placed under the Department of the Treasury (Smith \& Herring, 1924). The placement of the bureau within this department helps to note the view of immigration as economic during this time period. The current point of entry at Ellis Island was made official. The Mexican and Canadian borders would be monitored by 24 hour border enforcement. Medical inspections were to be conducted by 
the Marine Hospital Service for all new immigrants. The Bureau of Immigration included a superintendent and 27 staff (Daniels, 2004).

In 1895, the chief of the Bureau was renamed the Commissioner General of Immigration. At this time, the Commissioner General set the policy that excluded immigration of "paupers, persons suffering from a loathsome or dangerous contagious disease, and polygamists" (Smith \& Herring, 1924, p.8).

The second Commissioner General of Inspection, Terence V. Powderly, was appointed by McKinley in 1897 and served until 1902 (Daniels, 2004). Powderly was a member of the Knights of Labor; thus his appointment started a Republican presidential tradition of appointing the Labor Secretary as the Commissioner of General of Immigration. During his time in this position of power, Powderly is most known for his use of skewed statistics as a reason to restrict policy.

\section{Gentlemen's Agreement of 1906 to 1907}

The basics of the Gentlemen's Agreement will be discussed followed by CLEIM application to this policy. The Gentlemen's Agreement was composed of six notes between the United States president, Theodore Roosevelt, and the Japanese ruler, Baron Kentaro Kaneko. These letters asked Japan to supply no new passports for U.S. travel except for previous Japanese immigrants to United States or family of current Japanese immigrants (Vought, 2004). The Japanese Government agreed to this policy in an attempt to stop future policies such as the Chinese Exclusion Act that would completely restrict Japanese immigrants. The head tax was increased to $\$ 4$ per person from the previous $\$ .50$. In addition, the first United States Immigration Commission, known as the Dillingham Commission, was established to investigate immigration dynamics (Daniels, 2004).

\section{International Situation}

The years of 1906 and 1907 brought much change for governing bodies throughout the world. In Russia, the first house of parliament was opened. This house called the Duma opened in St. Petersburg. Protests by the Russian people resulted from the change to something new. 
Similarly, the Philippines held the first parliamentary elections in the history of that country (Wikipedia, 2006).

Change was sparked by the Industrial Revolution influence on the movement of people from rural to urban living situations. As a result, differences occurred in job situations, family structure, and the treatment of children.

\section{National Situation}

The Industrial Revolution encouraged many southern black males to move north to seek employment. Competition between black males and immigrants for similar jobs increased the already toxic anti-immigrant sentiment (Wikipedia, 2006).

In other class difficulties, Vought (2004) suggests that the Gentlemen's Agreement appealed to Japanese elite by fictitiously excusing racism as a working class problem. In actuality, the restrictions of the policy led not to a decrease in working class labor but instead assured the restriction of mostly members of the Japanese upper class. The Japanese upper class were considered more equal to American and European Gentlemen; thus more of a threat to the American ideals.

Influence Groups

Nativist groups continued to place pressure upon the United States Government to restrict policy based on national origin (Daniels, 2004; Graham, 2004). Another anti-immigrant organization called the American Protective Association (APA) was the brain child of Henry Bowers from lowa. The APA formed in 1887 as a result of increasing power being received in Northeastern cities by Catholic immigrants (Daniels, 2004). The Archbishop of New York City, John Hughes, demanded more rights for Catholics through the power of voting rights. As a result, political voting machines that specifically increased the power of Catholic immigrants formed (Graham, 2004). The APA increased in numbers as the power of Catholic immigrants increased. Fears of a "papal plot on America" increased anxieties of these new and different immigrants. APA members were mostly in the Midwest and Northeast where numbers of Catholic immigrants were most concentrated. The APA continued to be a driving force against Catholic migration until the time of the Depression (Daniels, 2004). 


\section{Policy Changers}

\section{Bureau of immigration commissioner.}

Frank P. Sargent served as the $3^{\text {rd }}$ Commissioner from 1902-1908 in which his agenda included literacy tests, high restriction based on: moral differences, disability, age 17 and younger, and age 60 or older (Daniels, 2004). In addition, border patrol of the Mexican border was supplied more money. Sargent wanted to explore a way to move the majority of migration from the Northeast to the West and South. During Sargent's time, the Bureau of Immigration moved to the Treasury Department to the Department of Commerce and Labor (Theodoulou \& Kofinis, 2004). In 1906, naturalization was transferred to the federal level and so the department was now responsible for both enforcement and service.

President.

Prior to the presidency, Theodore Roosevelt's birth circumstances and life history influenced his beliefs concerning immigration. His family tree included Dutch immigrants (1648) and Scottish/English/French heritage immigrants. He served as the United States Civil Service Commissioner (1889-1895) and maintained an outspoken stance against the American Protective Agency while encouraging the Americanization of the new American race. Roosevelt's belief in this new race revolved around successfully incorporating immigrants into the American melting pot society. Roosevelt served on a special unit, called the Rough Riders, during the Spanish American War. It is well-known that this group of cavalry was a mixture of individuals with different ethnicities. It is suggested that Roosevelt's experience with the Rough Riders sparked his later idea of a melting pot society. In addition, Roosevelt's positive feelings toward other cultures had been melded during the Russo-Japanese War (Vought, 2004).

Theodore Roosevelt (1900-1908) assumed the presidency after the assassination of William McKinley (Vought, 2004). Roosevelt believed in the superiority of the white race but due to historical dominance rather than biological reasons. A strong belief in bringing all citizens into the melting pot of the American standards in morality and living conditions was of utmost importance during this presidency. Roosevelt believed in the strength of the melting pot while restricting immigration of individuals considered undesirable. If immigration focused only on those 
immigrants that could successfully assimilate, America would receive new gifts. It was to the benefit of the nation and the individual migrant not to accept those migrants believed unable to fit into society. Roosevelt truly saw this as a win-win situation, both for the United States and the individual immigrant. To this end, Roosevelt hoped to change policy by encouraging the melting pot idea, supplying the labor market with needed workers, and encouraging Americanization of all new immigrants. Those unable to Americanize were deemed "undesirable". Typically this played out as future class based restrictions. Roosevelt toured the poor areas of the New York City first with labor leader Samuel Gompers and later with the NYC Police Commissioner, Jacob Riis (a Danish immigrant), to raise his awareness of immigrant living conditions.

\section{Dillingham commission report.}

The Dillingham Commission was created by the Gentleman's Agreement, Section 39, to entail a 9 member committee to examine immigration and report to Congress with the findings in order to provide recommendations for change (Zeidel, 2004). The following three members were selected by the president: Jeremiah Jenks (immigration expert), Charles P. Neill (immigration expert), and William Wheeler (businessman). The following three members were selected by the House of Representatives: Benjamin F. Howell (public servant), William S. Bennett (known humanitarian), and John Burnett (restrictionist). From the Senate, William P. Dillingham (public servant) and Henry Cabot Lodge (restrictionist) as well as one other person that changed places several times due to untimely deaths. While Daniels (2004) suggests that the research and report were written from the current status quo beliefs of negativity versus non-WASP immigrants, Zeidel (2004) suggests attempting to understand the report within the historical context of the early 1900s. A time period known as the Progressive Era in which society was attempting to improve the socioeconomic conditions of the country. Time period characteristics included: government intervention as positive, social betterment attempts, and the use of science as a way to examine social problems in order to create change. The Dillingham Commission has been labeled as unscientific in nature and rather narrow in the consideration of various cultures. Perhaps this was the best science available at the time, asserts Zeidel (2004). Science investigations included a visit and investigation in Europe, examination of U.S. data and visits to 
U.S. cities, as well as Franz Boas' physiological study of immigration assimilation through measurements, known as craniometry, to examine changes in the bodies of immigrants to determine how they have assimilated. In fact, the report focused 39 of the 41 volumes on the research, which included information on immigrant jobs, wages, and living conditions. Today, we are unable to examine these 39 volumes since Congress issued an order for the Department of Labor to destroy these papers during World War I.

Inclusion vs. Exclusion Level

The Policy Response Continuum assigns a negative 1.5 to the Gentlemen's Agreement due to this policy further restricting an entry ban on the Asian race (Timmer \& Williamson, 1998) (See Table 1.)

\section{Policy Change Consequences}

One unintended consequence of the Gentlemen's agreement entailed the start of the picture bride phenomenon. Picture brides were young women chosen from a picture to wed a Japanese man currently living in America. Other than written correspondence, there had been no previous connection between groom and bride. The young bride would then travel to America to live with her new husband (Daniels, 2004).

Another consequence of the Gentlemen's Agreement was the Dillingham Commissions final report recommendation of numerical restriction through the use of quotas (Zeidel, 2004). This recommendation was obscured for years by the continued debate and concentration over the use of literacy tests. Quotas were later used but only after the numbers of migrants had grown by numerous proportions. It is difficult to say the changes that would have transpired from earlier use of quotas (Zeidel, 2004).

\section{Historical Context between United States Immigration Policies}

Between the Gentlemen's Agreement and the Immigration Act of 1917, the election of United States presidents Taft and Wilson, as well as the beginnings of World War I, were noted. President William Howard Taft (1908-1912)

President William Howard Taft (1908-1912) inherited Roosevelt's immigration policies. Relying heavily on the Secretary of Commerce and Labor, Nagel, for immigration decisions, Taft 
encouraged more liberal policy then his predecessors with ideas such as rejecting the differences between old and new immigrants and speaking negatively on the idea of a literacy test. In fact, Taft vetoed the literacy test bill on the eve of leaving the presidency (Vought, 2004). Perhaps the liberal policies were also in part due to Taft's experience as the first Civil Governor of the Philippines. In that role, he attempted to unify and civilize the population through the use of English as a single language all tribes could learn to increase the communication across tribes (Vought, 2004).

Taft understood helping those inherently inferior as the nature of the American citizenry and thus encouraged assimilation of immigrants through the encouragement and help of the citizenry. The more liberal ideas of Taft and Nagel were balanced by the Eugenicists beliefs of the Ellis Island Commissioner, William Williams (Vought, 2004).

President Woodrow Wilson (1912-1916)

Born in Augusta, Georgia and living his formative years in Columbia, South Carolina, Wilson believed that class and ethnic conflicts were due to "valuing private interests over the public interest" (Vought, 2004, p.94). Due to this belief, Wilson attempted to unify all classes and races into a homogeneous middle class through education, policies, economic changes, and promoting these specific ideals. Wilson agreed that newer immigrants from the South and East of Europe, as well as Asians, were like African Americans in that many citizens did not want these groups in the country. Combining the idea of unity and homogeneity with the idea of "unwanted races" underscored the desire for similar moral, cultural, and physical characteristics of immigrants in order to reach this desired level of unity. A catch phrase well known from Wilson involved the desire to rid America of "hyphenated" Americans (p.94). "Hyphenated" Americans were defined as those Americans that wanted to change in ways considered American while keeping his/her own homeland traditions. To decrease hyphenation, education, the political system, and eradicating America of urban voting machines would be the first steps.

Wilson appointed Anthony Caminetti, the Commissioner General of Immigration (Vought, 2004). Caminetti was previously known for his lack of support of the California Japanese Land Law in 1913 which attempted to stop all people of Asian decent from the right to own property. In 
addition, Wilson appointed Frederic $\mathrm{C}$. Howe as the Commissioner of Ellis Island who is renowned for reversing much of the restrictive changes put in place by Williams. Howe made strides to change Ellis Island into a beautiful and hospitable place with trees, benches, and playgrounds for children (Vought, 2004).

During World War I, Wilson believed that America could symbolize an example of unity to the world (Vought, 2004). This idea is best noted in Wilson's work toward the League of Nations. International focus meant a lack of presidential focus on wartime hysteria within the United States. Historians believed this negative sentiment translated into anger toward all immigrants but most severely towards German immigrants. Anger culminated in the April 5, 1918 lynching death of Robert Prager, a German immigrant, in Illinois (Vought, 2004).

Before leaving office, Wilson vetoed the proposed Immigration Act of 1917 bill that was originally called the Burnett Bill due to the focus on literacy tests. It is believed that wartime experiences greatly influenced Wilson's decision to not support such a restriction oriented bill. The president's veto was overridden and the Immigration Act of 1917 was signed into policy (Vought, 2004).

\section{Immigration Act of 1917}

The basics of the Immigration Act of 1917 will be addressed followed by the discussion of CLEIM application to this specific policy. The United States was the second nation known to impose a literacy regulation on immigration regulations. The first was the Colony of Natal in the year 1898 (Daniels, 2004). The years of struggle concerning whether to include literacy as a dominant part of immigration policy ended with the implementation of the Immigration Act of 1917 (Timmer \& Williamson, 1998). To pass the literacy component, immigrants were asked to read any language. This form of the literacy test was a compromise since many senators and representatives wanted the literacy test to focus only on the ability to read English. Concessions were made just to ensure the ability to read any language, rather than English only. In addition to the literacy component, the Immigration Act of 1917 codified all previous immigration policy. The Bureau of Immigration was moved from the Department of the Treasury to the Department of Commerce and Labor. An Asiatic bar zone was put into place that virtually restricted all Asian 
immigrants based on actual degrees of latitude and longitude. The head tax was increased from $\$ 4$ to $\$ 8$ per person to be paid by the immigrant. Retroactive deportation was allowed up to five years after immigrant arrival (Daniels, 2004).

\section{Trigger Event}

World War I, lasting from 1914 to 1919, was fought by the Allied Powers versus the Central Powers. This war was known for two large changes in warfare: (a) the use of trench type battle in which officers were confined to small ditches for fighting and (b) the first large scale use of planes and bombs for fighting. World War I changed the ruling elite power of the following empires: the Russian Empire under the Romanov's, the German Empire under the Hohenzollerns, the Austro-Hungarian Empire under the Habsburgs, and the Ottoman Empire under the Ottomans. All four of these empires had roots back to the time of the Crusades. The post-war changes are attributed to economic devastation that helped contribute to the rise of the Nazi's in Germany, the Bolshevik Revolution in Russia (and later Communism), and the ground work for the Cold War between Russia and the United States (Wikipedia, 2006).

To further understand the impact of WWI on United States policy, the factors of causality, severity, incidence, proximity, and crisis are helpful in understanding why the war impacted policy in such a drastic fashion (Theodoulou \& Kofonis, 2004). The world blamed the cause of the war on Austria and Germany; resulting in punishment oriented post war decisions rather than decisions based on lessening the likelihood of future conflicts. The high level of severity was based on: a) the number of countries involved in the battle, b) the financial cost to individual countries, and c) the numerous casualties. Incidence was low since this was the first large scale war in world history. Although the proximity of the war was not within the boundaries of United States soil, it created a level of fear and worry over "what if" the war allows different types of people to take over American lands. The crisis level was moderate due to the combination of a high severity, a moderate proximity, and a low incidence.

\section{National Situation}

During the year of the passage of the Immigration Act of 1917, Wilson cut diplomatic relations between the United States and Germany and on April $6^{\text {th }}$ the United States officially 
declared war on Germany. As the numbers of males increased to leave for war, job rosters required workers to provide for the war time effort. As such, the Immigration Act of 1917 allowed for active recruitment of Mexican workers to fill empty labor jobs due to World War I starting on May 23, 1917. Most of the needed labor worked on farms, railroads, mines, and manufacturing jobs (Daniels, 2004).

International Situation

During World War I, and soon after the completion of the war, American citizens worried about poor Europeans flocking to the United States due to the poor post-World War I economy. Fears and negative attitudes toward immigrants were only increased when word of the Bolshevik revolution in Russia reached the states. Socialist type regimes were blamed for World War I. Stereotypes attributed to Germany and Austria, during the war, were also attributed to czarist ruled Russia. As a result of czarist rule, migration from Eastern European countries was not welcomed to the U.S. As United States unemployment rose to $12 \%$, fear and animosity concerning new immigrants increased (Daniels, 2004).

Influence Groups

Nativist groups celebrated a victory with the tightening of immigrant admission based on the literacy tests. Members of many societies hoped that new arrivals would have to be able to read English rather than the ability to read any language. Although not the English only restrictions hoped for, restrictive changes of any type were supported by influence groups against immigration. Anti-immigration groups continued to push for the use of quotas to specifically target numbers of migrants allowed into the country as had been suggested by the Dillingham Commission (Graham, 2004).

\section{Policy Changers}

Theodore Roosevelt served a second term as President from 1916 to 1920 . Policies of his previous presidency and those implemented during Wilson's presidency were continued during this time (Vought, 2004).

Exclusion vs. Inclusion Level. 
The Policy Response Continuum places the Immigration Act of 1917 as a negative 3.5 due to the enforcement of literacy tests as a measure to decrease numbers of immigrants (Timmer \& Williamson, 1998) (See Table 1.)

\section{Immigration Act of 1921}

The policy basics of the Immigration Act of 1921 are discussed followed by the implementation of CLEIM to this specific policy. The Immigration Act of 1921 marked the use of quotas as a way to restrict specific groups of migrants based on national origin (Daniels, 2004). After much discussion, the policy makers decided to use the 1910 census as the basis for the quotas in which $5 \%$ of the numbers of immigrant nationality groups would be allowed entrance into the United States. Preferred immigrants included artists, intellectuals, and learned professors with specialty status. A relative preference was added but this type of immigrant had to meet all other entrance requirements in order to enter without being included in the quota numbers (Daniels, 2004).

International Situation

During the year 1921, change was occurring throughout the world. The Irish War of Independence was fought between Ireland and England resulting in the independence of Ireland. The second Peace of Riga was signed to end the Polish-Soviet War although feelings of resentment between these two Eastern European countries remained. Soon after the completion of the war, the Soviets annexed both the Ukraine and Belarus. In Germany, Hitler was elected the chairman of the Nazi party; thus marking the first step in his future rise to power (Turk, 1999).

\section{National Situation}

The 1920 s found an increase in urbanization based on mechanization decreasing the need for agricultural work (Briggs, 2003). Contrary to popular belief, the depression of the late 1920 s began in the rural areas much earlier due to massive migration of workers from the rural to urban areas. It is suggested that this early movement of peoples contributed to the complete blight of rural dwellers during the time of the Great Depression. Pull factors to urban life included higher wages for laborers and an increase in production jobs during World War I. During war time, numbers of migrants decreased, other than those that could cross the Canadian and 
Mexican borders, while rural whites and blacks moved to the cities after the virtual collapse of the cotton trade (Briggs, 2003).

\section{Influence Groups}

The increase in mechanization further strengthened the power of labor employers during the 1920s (Briggs, 2003). Labor at times has encouraged immigration and at other times has discouraged immigration; depending on the numbers of available American citizens to fill open job opportunities. During the 1920s, American soldiers had returned from war to refill labor jobs and as such the workforce did not require the large numbers of migrants previously needed. Negativity did not completely turn on the immigration though as the prosperous "golden twenties" had enough job possibilities for all to obtain employment.

\section{Policy Changers}

The presidency of Warren G. Harding (1920-1923) was one of increasing restriction and exclusion in part due to the residual effects of World War I (Vought, 2004). Harding's own feelings toward immigration were greatly influenced by his U.S. Senate position (Ohio) during World War I in which he developed a strong affinity for patriotism and Americanization. The term "one-hundred percent American" became the catch phrase of the Harding campaign (p.160). The lack of assimilation for specific groups of immigrants was no longer placed strictly upon the new immigrant but shared by those American citizens not providing the proper education to American's newest members. Talk of assimilation did not include individuals of Asian or African decent since it was believed these two particular groups were unable to assimilate.

President Harding supported the new Labor Secretary, Oscar Staus' high restriction beliefs of requiring mental testing and more stringent inspections of newly arrived immigrants (Vought, 2004). Straus believed that a "rat type" of immigrant existed that included the "feeble minded, imbeciles, insane, psychopathically inferior, reds, anarchists, and communists" (p.174). The "beaver" type of immigrant was acceptable due to both its hard working and docile nature (p.174). 
Harding's last known speech on immigration in 1923 included topics on decreasing the numbers of illegal immigrants and focusing on immigrant quality over quantity. It is believed that Harding would have supported the Immigration Act of 1924 if he had lived (Vought, 2004). Inclusion vs. Exclusion Level

The Policy Response Continuum labels the Immigration Act of 1921 as a negative 4.5. A portion of this bill sets quotas and continues to enforce the literacy tests from 1917 but this policy also allows for increased migration due to family reunification making the total a Negative 4.5 (Timmer \& Williamson, 1998) (See Table 1.)

\section{Immigration Act of 1924}

The policy basics of the Immigration Act of 1924 are discussed followed by the implementation of CLEIM to this specific policy. The Immigration Act of 1924 derived numbers from the 1890 census (Daniels, 2004). This specific census was noted for the highest numbers of WASP immigrants; thus higher levels of immigrants from Northern and Western Europe would be allowed entrance in comparison to those from Southern and Eastern Europe. No limitations were placed on Western Hemisphere migrations due to the continued need of migrant labor. The Caribbean Islands' quotas were set with the numbers of the original country of colonization (thus decreasing numbers from African decent nations). Visas and photographs would now be required of all new immigrants in order to start tracking immigrants entering and exiting the country. The head tax was raised from $\$ 8$ to $\$ 9$ per immigrant. As with the previous policy, an increased focus on family reunification was noted as extremely important. Although a family based immigrant had to meet all other policy requirements before being considered for this type of entrance (Daniels, 2004).

International Situation

During 1924 , the following changes of historical significance occurred: Lenin died and Stalin started the process of taking power in Russia, fascists won the election in Italy by $2 / 3$ of the vote, and the Geneva protocol was adopted by the League of Nations as an attempt to strengthen collaboration among countries (Hingley, 2003). 
In Germany, Hitler attempted to seize power of the local government in Munich, Germany, during an incident known as the Beer Hall Putsch. For this failed attempt, Hitler was sentenced to five years in prison. Of the five year sentence, Hitler only served 9 months in jail. During this nine months, Hitler wrote his well-known novel, Mein Kampf (Turk, 1999).

\section{National Situation}

The year of 1924 was one of firsts for the United States. President Coolidge gave the first radio address on February 22,1924 . On June 2, 1924, the Indian Citizenship Act was signed by Coolidge therefore granting citizenship to all Native Americans born within the Continental United States. The first state execution using the gas chamber was performed in Nevada (Vought, 2004).

It is not surprising that the mid-1920s was a year of firsts. The 20 s fondly called the "roaring $20 \mathrm{~s}$ " or the "golden $20 \mathrm{~s}$ " were symbolic of increased financial gains for the elite classes, increased productivity, and readily available jobs. The success and prosperity of the 20 s would come to an end with the Great Depression.

\section{Influence Groups}

The strength of labor power continued into the mid-1920s (Briggs, 2003). Labor employers and unions were at times at odds due to the attempts to hire cheap labor versus union workers. Cheap immigrant laborers were routinely used as strike breakers. A strike breaker was despised by other workers and treated to name calling and physical abuse. As numbers of immigrants were placed in this position, stereotypes of the immigrant workers as a thief, shifty, and untrustworthy grew.

Policy Changers

President Calvin Coolidge grew up in Vermont and spent the majority of his adult life in Boston, Massachusetts as the Governor's assistant; thus experiencing interaction with immigrants on a daily basis (Vought, 2004). Coolidge was directly influenced by Charles Garman's class at Amherst College in which teachings centered on all people as equal partners in society. The idea of social Darwinism was dismissed as superiorly of specific groups of people over other groups with less power and prestige. 
Although President Coolidge (1923-1928) signed the Immigration Act of 1924, it was believed his agreement was only given due to respect of the previous President (Vought, 2004). Coolidge expressed his unhappiness with the continued exclusion of many Asian groups. The president did support restriction, but immigration restriction based solely on the numbers of immigrants the country could reasonably accept not based on national origin. In other words, restriction based solely on economic conditions. Assimilation was noted as important to encourage unity and citizenship and could be encouraged through adoption of U.S. ideas, learning the English language, and more importantly the adoption of U.S. cultural traditions while maintaining their culture and language traditions. This belief of learning the new and maintaining the old was a new idea at this time in history (Vought, 2004).

Inclusion vs. Exclusion Level

As with the Immigration Act of 1921, the Policy Response Continuum labels the Immigration Act of 1924 as a Negative 4.5. A portion of this bill sets more restrictive quotas than 1921 and continues to enforce the literacy tests from 1917, but this policy also allows for increased migration due to family reunification, making the total a Negative 4.5 (Timmer \& Williamson, 1998) (See Table 1.)

Historical Context between United States Immigration Policies

Between the Immigration Act of 1924 and the Smith Act of 1940, President Hoover assumed the United States presidency, the Great Depression occurred, and the Immigration and Naturalization Service was formed.

Presidency of Herbert Hoover

The Presidency of Herbert Hoover (1928-1932) was noteworthy in that Hoover was one of the first presidents without previous elected official experience (Vought, 2004). However, Hoover did serve as the United States Secretary of Commerce under both Harding and Coolidge where his experience created negative feelings toward immigration restriction. Hoover truly embraced the melting pot concept and thus called for repeals of the quotas based on the 1890 census. 
The intentions of change stopped with the plummet of the stock market known as the Great Depression (Vought, 2004). Hoover was virtually forced to sign an executive order stopping all immigration; the country had to deal with the poor and hungry currently in the country without opening her arms to others in need. Hoover's changes helped to protect the few jobs available for current residence of the United States (Graham, 2004). These beliefs were discussed in a radio address to the Union on June 15, 1931 (Vought, 2004).

The Great Depression and Migration

Some Mexican immigrants were forced back to Mexico in an attempt to reclaim jobs for white American citizens (Daniels, 2004). Little attempt was made to determine if those forced back to Mexico were immigrants or actual citizens of the United States. This group of forced emigrates have become known as the repatriados. The Secretary of Labor, Frances Perkins, attempted to decrease the corruption inherent in this practice with little ability to exact much change (Daniels, 2004).

Immigration Bureau Change

The Bureau of Immigration changed to the Immigration and Naturalization Service (INS) in 1933 (Daniels, 2004). With this change, the INS was housed within the Department of Justice (DOJ). This change signaled a shift to prosecutorial functions for immigration policy. Immigration decreased in importance and short term decisions to handle current numbers of migrants became a focus. Without long term planning, DOJ short term decisions many times led to unintended consequences due to the lack of congruence between policy formulation and policy implementation (Briggs, 2003). The Senate and House Judiciary committees were actually responsible for implementing policies decided upon. These committees were typically made up of lawyers and not policy experts. Immigration law slowly became a lucrative field for lawyers to work. A law type orientation led to a focus on individual immigrant circumstances with little thought to the long term collective welfare changes created by new policy (Briggs, 2003).

\section{Smith Act of 1940}

The policy basics of the Smith Act of 1940 are discussed followed by the implementation of CLEIM to this specific policy. The Smith Act of 1940 , also known as the Alien Registration Act, 
changed immigration policy from a form of protection to persecution (Daniels, 2004). Criminal punishments could be held against "aliens involved in subversive activities" (p.83). Increased numbers of community leaders expected of Communist connections were jailed due to fears connected with all things communist. Naturalization restrictions were started for anyone deemed as opposed to the United States laws and/or form of government. In addition to photos and visas, immigrants now had to register and provide fingerprints to the United States Government. Now, a specific form was required if an immigrant moved from one residence to another in order to track movement of immigrants within the United States (Daniels, 2004).

International Situation and National Situation

World War Il era (1939-1945).

The start of World War II marked the first use of many workers still previously unemployed during the Depression (Briggs, 2003). During the time of the war, $60 \%$ of able bodied males were enlisted or were drafted to fight; leaving open jobs that needed filling for the country to function properly. A labor force was recruited through Franklin Delano Roosevelt's (FDR) War Manpower Commission in conjunction with the United States Employment Service. Many positions were filled by women, older workers, minors, and immigrants (Briggs, 2003).

Immigrant recruitment was specifically helpful in filling open agricultural jobs. This particular recruitment was similar to the programs instituted during World War I. Active recruitment lasted from July 1942-April 1943 and was known as the Bracero program (Briggs, 2003). An additional 50,000 workers were sought in a separate program aimed at building new railroads for use of the transport of military goods (Daniels, 2004). At the peak of this program, approximately 500,000 workers were employed, totaling a record 4.7 million, during the time of the program. The program was not officially ended until 1964 and this was due to political pressure that mounted at that time (Briggs, 2003). Graham (2004) suggests that the Bracero program taught Mexican workers to move north for employment to assist families back home to survive. After the end of legal channels, the increase in undocumented migration greatly increased. 
No United States policy changes occurred during World War II to encourage or discourage immigration to specific countries touched by Communism (Daniels, 2004). In 1938, FDR created an advisory committee on immigration and refugees for the League of Nations by appointing Myron C. Taylor as ambassador. This committee first attempted to create an intergovernmental unit on refugees in London under the chairman, George Rublee. The first agreement was to allow for the migration of 400,000 Jewish people into immigrant receiving countries over a five year period. The majority of World War II refugees settled in England (Daniels, 2004).

While work was occurring at the International level, the focus within the United States centered on national security concerns (Theodoulou \& Kofinis, 2004). Wagner-Rogers bill of 1939 failed to pass the United States Congress (Daniels, 2004).This bill would have allowed 20,000 German children to the United States under refugee status without being included in the restrictive immigration numbers. In addition, in 1941, the United States Congress attempted to restrict immigration from Japan, Germany, Italy, Hungary, Bulgaria, and Romania due to Communist sentiment worries. In 1943, war relocation authorization set up Japanese internment camps in which 120,000 Japanese, 2/3 American citizens, were forcibly placed. A loyalty questionnaire was imposed in which individuals were required to swear allegiance to the United States and denounce all foreign powers. This component led to some Japanese Americans denouncing United States citizenship and returning to Japan when able. In addition, the U.S. encouraged fifteen South American countries to forcibly deport Japanese, German, and Italians living in these countries to the United States for placement within internment camps. A total of 2264 Japanese, 4058 Germans, and 288 Italians were part of this process (Daniels, 2004).

The following acts were set up during the World War II time period to assist refugees: Displaced Persons Act (1948); Refugee Relief Acts (1953/1954); and the Refugee Escapee Act (1957). The use of detention centers to deter untrue asylum was set in place. Extended Voluntary Departure (EUD) involved allowance to live and work in United States as a refugee with the agreement to return to his/her home country when conditions were most acceptable. Specific 
countries involved with this program included: Ethiopia, Uganda, Iran, Nicaragua, Poland, and Afghanistan (Churgin, 1996).

United nations formed (1945).

The United Nations was formed as an international governing body to facilitate cooperation of international agreements and security as well as to support economic development and social equality (Wikipedia, 2006).

Influence Groups

The influence of radio and television during this time period allowed individuals to more readily assert feelings surrounding WWII. The fear of communism possibly infiltrating into America spread fear by the expansion of the United State's media. The power for change, rather positive or negative, demanded by the status quo was evident as citizens supported ferreting out Communism in America.

Policy Changers

Joseph McCarthy, a Republican Senator from Wisconsin, is perhaps best known for his part in the aggressive attempts to find Communists living within the United States from 19501954. The hunts for Communists known as "McCarthyism" grew out of the Second Red Scare that began in the 1940 s as an attempt to rid the nation of anyone suspected of Communism. Names were placed on lists and people questioned by McCarthy to his satisfaction. Inclusion vs. Exclusion Level

The Policy Response Continuum labels the Smith Act of 1940 as a negative four due to the changes in policy restriction of fingerprinting, photos, and visas (i.e. -5 ) and the recruitment of agricultural guest workers (i.e. +1 ) combined. Naturalization was virtually placed at a stand still due to worries of a Communism invasion of the United States. Immigration numbers dipped lower than since World War I during the restriction based policy (Timmer \& Williamson, 1998) (See Table 1.)

\section{McCarran- Walter Act of 1952}

The policy basics of the McCarran-Walter Act of 1952 are discussed followed by the implementation of CLEIM to this specific policy. The McCarran-Walter Act of 1952, also known as 
the Immigration and Nationality Act, re-codified previous immigration law (Daniels, 2004). Changes from previous policy included: differences in quotas for Europe and Asia, deportation rules, and the definition of subversive activity. Quotas were now from the 1920 census which allowed for larger numbers of immigration from Southern and Eastern Europe. In addition, the Asiatic bar zone was removed resulting in an increase in Asian immigrants. This quota change did considerably narrow the numbers from Caribbean countries due to the decision to continue to calculate numbers based on previous European colonial power. A focus on special consideration for skilled workers and family reunification was more strongly enforced. International Situation

West Germany began paying reparations to Israel to make atonement for the atrocities against the Jewish people during the Holocaust. The agreement included paying over 3 billion Deutsche Marks to Israel over a period of time. While West Germany was making peace with Israel, communication between the separate German spheres became increasingly strained (Turk, 1999).

The Cold War alignment pitted United State's allies against Russian allies. The United States and her allies feared the spread of Communism throughout gullible $3^{\text {rd }}$ world countries in Asia and Africa. Russian control of the seven Eastern European satellite countries only further strengthened western worries of uncontrolled Russian power and control. Western countries levied sanctions against countries with economic ties with Eastern Europe in an attempt to further isolate Communist influence.

\section{National Situation}

Similar to the international situation, America was still caught in the "red scare" of McCarthyism during this time period. "Differentness" was associated with Communism and Communism was associated with godlessness. The American focus on Judea-Christian principles increased the fear of a godless type of government.

\section{Influence Groups}

The increasing influence of the media on American points of view can be pinpointed to the advent of the television as agent of change (Wikipedia, 2006). The average American could 
watch the McCarthy questioning and make judgments concerning what was presented on the television. The fear taking hold of the nation was perhaps best symbolized by the building of bomb shelters in schools and public places for fear of nuclear war by the Communists. Children grew up fearing what would happen if the Communist were to come to power in the United States. The fear associated with this movement was so strong that policies changed as a result. Policy Changers

McCarthy continued to be the main individual effecting policy change during this time period by investigating people suspected of Communist ties (Vought, 2004).

The next United States President, Dwight D. Eisenhower (1952-1956), believed immigration was a foreign policy decision, rather than an individual nation decision, and as such focused policy during his tenure on refugees rather than immigrants per se (Daniels, 2004). Policy Change

The McCarran-Walter Act unsuccessfully attempted to incorporate parts of a proposed bill called the "wetback bill" to provide more funding for border patrol on the Mexican border (Daniels, 2004, p.121). A "Texas proviso" allowed for an exemption for employment of undocumented workers as not falling under the harboring law and thus free from criminal sanctions (p.121). President Truman suggested an immigration policy review every three years for needed changes to be called the "Whom Shall We Welcome Report" (p.122). Inclusion vs. Exclusion Level

The Policy Response Continuum labels The Walter-McCarran Act of 1951 as a negative two. Although the policy continued registration rules, reworked deportation regulations, and continued selective source countries such as evident from a negative three type policy (especially from the Caribbean area), the policy increased numbers of migrants for family unification as well as allowing specific types of immigrants into the country more like a positive one; thus totaling a negative two score (Timmer \& Williamson, 1998) (See Table 1.)

Historical Context between United States Immigration Policies 
Between the Walter-McCarran Act and the Immigration Act of 1965, John F. Kennedy assumed the United State's presidency and was assassinated. In addition, the Bracero program was officially ended and the civil rights movement gained momentum.

John F. Kennedy (1961-1963)

John F. Kennedy planned to phase out the quota plan over five years to replace previous policy with the following categories: skills, reunification, and first come first served (1963).

Kennedy's policy considerations also included the need for skilled workers to obtain employment before immigrating to the United States. Policy should allow for unskilled workers but different restrictions should apply. Kennedy's ideas for immigration policy change were not passed before his assassination in 1963 (Daniels, 2004).

\section{End of the Bracero Program}

In 1964, the new labor secretary, Willard Wirtz, under intense political pressure, stopped the legal agricultural programs allowed under the Walter-McCarran Act (Daniels, 2004). Only ad hoc approval of workers could be applied for. "California became addicted to Mexican labor" previous to this change and so had difficulty adjusting to the changes instituted by Wirtz (p.142). The pull factors of jobs in California and previous policies allowing northward migration for work to Latino workers helped encourage undocumented migration (Daneils, 2004).

The United States attempted to continue a version of the guest worker program under the $\mathrm{H} 2$ visa of the Immigration and Nationality Act of 1952 (Graham, 2004). This H2 visa forced employers to prove that no American workers were available for a specific job before allowing recruitment of foreign workers. Although guest worker programs offer promises regarding wages, duration of employment, housing, and health insurance policies are not truly in place to enforce these promises (Graham, 2004). Instead, studies note lower wages and power when higher numbers of guest workers are used versus U.S. citizens (Lanham, 2000).

Civil Rights in the United States

The Civil Rights Act of 1964 encompassed groups pulling together to push for reform (Graham, 2004). This Act abolished the Jim Crow Laws of the South and disallowed discrimination based on race, religion, color, sex, or national origin in government, employment, 
and public facilities. The later program of Affirmative Action was made possible through the passage of the Civil Rights Act of 1964 (Graham, 2004).

Soon after the passage of the Civil Rights Act, the United States military committed troops in the support of South Vietnam from 1965-1973 in what would become the Vietnam War. During the Vietnam War, the attention given to immigration decreased. Drastic demographic changes were warning of global changes, but the warnings were not noted until much later. After the war, changes were fairly well entrenched through the immigration receiving countries (Graham, 2004).

\section{Hart-Cellar Act /Immigration Act of 1965}

The policy basics of the Immigration Act of 1965 are discussed followed by the implementation of CLEIM to this specific policy. Lyndon Baines Johnson assumed the presidency after JFK's assassination in 1963. The Immigration Act of 1965 closely followed the recommendations that JFK was unable to put into place before his death (Daniels, 2004). Changes in the Immigration Act of 1965 marked a shift from social to political reasons behind immigration policy as evidenced by the rise in narrow special interest groups (Briggs, 2003). Three main differences were noted from JFK's original policy recommendations: (a) the policy did not modify the quota system but ended it altogether, (b) a cap was placed on western hemisphere migration, and (c) the locus of immigration change was still by congressional committee (Daniels, 2004).

\section{International Situation}

Occupational and geographical changes can be partially explained by the internationalization of the United States economy and labor forces (Briggs, 2003). The economies of western nations (i.e. United States, England, France, Italy, and West Germany) became more interdependent on each other during this time. Importing and exporting of goods increased in the areas of food production, chemicals, automobiles, and oil.

\section{National Situation}

Policy changes were compounded by post 1965 labor market changes. Industrial shifts increased white collar/skilled labor market jobs while decreasing blue collar unskilled type jobs 
(i.e. agriculture, manufacturing, mining, and construction) (Briggs, 2003). Furthermore, population growth shifted to the growth of the non-agricultural South Atlantic (Delaware to Florida), West South Central (Arkansas to Texas), and the Pacific Coast. The highest population declines were noted in the mid-Atlantic (New York, New Jersey, Pennsylvania) and the East North Central (Great Lakes Region). Both the size and composition of the labor force saw changes in gender, race, age, and ethnic composition as evidenced by the increase in female workers, the increase in non-white workers, the decrease in black male workers, and the high percentage, $67.2 \%$, of population in the workforce (Briggs, 2003).

\section{Influence Groups}

Beliefs held by the status quo were effected in the late 1970 s by the Americans Immigration Reform (FAIR) movement that focused on reduction of illegal entry (Graham, 2004). The terminology shifted to include both the term illegal aliens and undocumented workers. Illegal aliens were immigrants who were considered a drain on the American economy. The term undocumented worker signified an immigrant who was "recognized for service to America" through working while in America (p.106).

Chavez (2001) provides a portrait of magazine covers as the windows of popular belief and culture. In order to examine covers, this research would label covers as alarmist, neutral, or affirmative. Popular images included: assemblages, the Statue of Liberty, news photos, and directional images, images of masses of people, woman/child motifs, water/flood imagery, United States flag, and borders between countries. The first magazine cover involving immigration was in 1974 with an additional 5 covers following that year. The first covers' title was "How Millions of Illegal Aliens Sneak into the U.S." (p.90). Some covers were affirmative while others were alarmist. During all periods examined, a noted difference occurs in July of each year. This research suggests the idea of a nation of immigrants seen in a positive light is most at work in the month of our country's birth. (See Table 3.)

\section{Policy Changers}

Lyndon Baines Johnson's idea of the Great Society (1964) was announced at the beginning of his presidency. This was an attempt to end racial disparities in the United States 
through the establishment of programs such as Head start, Medicare/Medicaid, Upward Bound, VISTA, Job Corps, and neighborhood youth programs. Unfortunately, the Great Society was never fully funded due to the start of the Vietnam War (Daniels, 2004).

Policy Change

An unintended consequence of this policy was the drastic increase in chain migration (Daniels, 2004). Chain migration involves one member of a family coming to the host country and establishing employment and housing; allowing other members to move one by one to then establish their own work while residing with the first family member. Chain migration is most noted in the Latino cultures; thus between the changes with the Immigration Act of 1965 and the end of the Bracero program, numbers of migrants from Latin based countries greatly increased after 1965 . These changes allowed for the beginning discussions to center on illegal migration (Theodoulou \& Kofinis, 2004).

Inclusion vs. Exclusion Level

The Policy Response Continuum labels the Hart-Cellar Act of 1965 as a zero. This policy allows for a more liberal notion of immigration by ending the quota system but does continue to restrict based on the new political elements of skills, reunification, and date of application (Timmer \& Williamson, 1998) (See Table 1.)

Historical Context between United States Immigration Policies: The $1980 \mathrm{~s}$

After the Hart-Cellar Act, policy shifted to a focus on the economic association with migration. Undocumented numbers were the focus and the unrealistic numbers led to incorrect assumptions on which to base policy.

\section{The Economics of Immigration}

A policy debate formed in the 1980s that focused on the economic components of immigration. On one side immigration was seen as a supply of needed labor while on the other side immigration was allowing jobs to be taken from American workers (Graham, 2004). Attempts were made to understand this economic puzzle by asking well known economists to examine the economic situation and report to the nation. Borjas, a renowned Economist, noted the decreased social capital of immigrants in recent years. Furthermore, a net gain of 1 to 10 billion dollars is 
received in the United States, but this amount of money is offset by the $15-20$ million required to provide social services to the immigrant population (Graham, 2004).

Perhaps the economic situation encouraged the increase in worry centering on illegal immigration; thus restrictive immigration policies were pushed by the status quo (Lanham, 2000). During this period of history, negative attitudes of citizens were reinforced by the erroneous beliefs that: immigrants are usurping American culture, immigrants are taking quality housing and jobs, immigrants are forcing down the standards of education, immigrants do not want to learn the English language, and immigrants lower the political power while increasing the power of minorities. Bohon and Neal (2002) noted that one of the highest predictors of prejudice is level of English Only belief. Twenty-six states have English Only laws on the books.

\section{Undocumented Migration Concerns}

To understand undocumented migration, terminology is important to review. Two types of undocumented migration occur: entrance without inspection and visa over-stayers (Bean et al, 1990).

The first mention of undocumented (illegal) migration occurred in 1972 by the Immigration and Naturalization Commissioner, Raymond Farrell (Bean et al., 1990). Throughout the mid1970s, the INS commissioned Lasko Associates to gather data on the undocumented population. This research found 8.2 million undocumented with 5.2 million of this group deriving from Mexico. Years later the INS realized that this data was faulty but the damage by these numbers had already occurred. These numbers were discussed and reinforced as fact leading to strong citizen beliefs of uncontrolled, undocumented migration. Lack of understanding of the differences between the immigration terms of stock and flow contributed greatly to Lasko's incorrect statistics. Stock entails the number of immigrants residing in the United States at a particular time period. Flow entails the number of immigrants entering or exiting the country during a specific time period. When flow numbers are reported without discussing the differences between stock and flow, actual numbers of immigrants within that country during that time period are skewed. In order to fully examine both the stock and flow, research must possess information of the size, dynamics, and structure of the immigrant population (Bean et al., 1990). 
Throughout the late 1970 s, proclamations of lower numbers of undocumented migration from only 3 to 6 million were reported within explanations of the previously incorrect numbers (Bean et al, 1990).

Department of Justice Immigration Recommendations

On July 30, 1981, the Justice Department supplied recommendations concerning immigration in which the focus centered mainly on ways to reduce illegal immigration. Recommendations included: (a) increasing external controls, (b) strengthening enforcement of federal labor laws, (c) increasing fines to employers found hiring undocumented immigrants, (d) federal court injunctions against employers with continual practice of hiring undocumented workers, (e) making employers verify individuals available for work more stringently, (f) reestablishing the guest worker program of 50,000 Mexican workers over a 6 to 8 month period, amnesty to undocumented (mostly Cubans and Haitians), and (g) open the dialogue with the Mexican government to discuss ways to reduce undocumented migration (Lanham, 2000). Incorrect U.S. Policy Assumptions

Policy of the 1980s and early 1990s was based on incorrect assumptions; thus from the inception this policy was unable to accurately deal with the United States immigration difficulties (Laham, 2000). Policy was based on the following assumption: (a) legal migration always allows for an economic advantage to the U.S. and (b) illegal immigration was seen as an abuse of federal immigration law; thus against the idea of national sovereignty.

\section{Immigration Control and Reform Act (IRCA) 1986}

The policy basics of the Immigration Control and Reform Act are discussed followed by the implementation of CLEIM to this specific policy. The Immigration Control and Reform Act (IRCA), in the final form, was a compromise decided upon by a special committee meeting of both the House and Senate (Chavez, 2001). This decision was an attempt to examine the unintended consequences of the Immigration Act of 1965 (increased numbers of Asian and Hispanic immigrants) and to make changes based on those consequences. This was compounded by the 1980 s attitudes toward immigration focusing on fear, negative attitudes, and 
increased violence. In addition, IRCA was highly influenced by the 1981 Lasko report incorrectly suggesting such high numbers of undocumented immigrants (Daniels, 2004).

IRCA entailed the following components: broad amnesty, strengthening border control through increasing budget, a new classification of seasonal agricultural workers (SAW), lottery visas to target countries restricted by the 1965 act (i.e. Ireland \& England) and larger sanctions/punishments for employers hiring undocumented workers (Daniels, 2004). The budget for border control went from 36 billion dollars in 1986 to 480 billion in 1988 and 541 billion in 1989. Financial penalties toward employers hiring undocumented workers moved up from 250 to 2500 dollars per undocumented worker (Bean et al., 1990). IRCA granted legal status (amnesty) to 1.7 million undocumented individuals residing within the United States (Bean et al., 1990). National Situation

As part of IRCA, Barney Frank (Representative from Massachusetts) pushed for a clause making it illegal to discriminate against hiring immigrants on the basis of nationality (Lanham, 2000). This clause was in reaction to the problems experienced by Latino workers with many employers unjustly assuming the majority of individuals from Spanish speaking countries had false documents in an attempt to illegally gain employment. The clause was not included in its entirety but instead a narrower scope in which the Special Council for Immigrant Relations and Unfair Employment was established to investigate allegations of unfair hiring practices. In reality, Lanham (2000) reports that the advent of the council restricted the ability of legal immigrant workers to initiate lawsuits based on discriminatory practices.

International Situation

A period of terror reigned during this time in history. Libya is held responsible for a bombing of a clothing store in West Berlin known as a United State's soldier hang out. United States planes bomb the Liberian capital, Tripoli, as part of Operation El Dorado Canyon. Revolutionary cells kidnap United States and English reporters in response to U.S. bombing. The United States and Russia continued to focus on the Cold War animosities started post-WWII. The 1980s were known for large expenditures for nuclear arms programs in both countries (Daniels, 2004). 
Focus on Russia's nuclear power was again brought to the world's attention with the Chernobyl nuclear plant accident (April 26, 1986) occurred making the largest such explosion in history. Thirty one people were killed, nuclear chemicals infected hundreds of people, and large tracts of land in Belarus and the Ukraine were no longer inhabitable (Hingley, 2003).

Policy Changers: Ronald Reagan (1980-1988).

"The Reagan presidency represents a milestone in the history of immigration policy, insofar as it marks the beginning of two decades-long, on going effort to achieve comprehensive immigration reform" (Laham, 2000, viii).

Immigration was not high on the presidential agenda when Ronald Reagan took office in 1980 (Lanham, 2000). Soon after taking office, the status quo demanded immigration change due to the ramifications of the 1965 policy (i.e. the unintended consequence of increased legal and illegal immigration). The previous president, Jimmy Carter had suggested, as early as 1977, that examine illegal migration be examined, but Congress did not act upon the recommendation. Instead congress formed the Select Commission on Immigration and Refugee Policy (SCIRP) to explore immigration in its entirety rather than to handle the most pressing concern of undocumented migration. The SCRIP report was not completed when Reagan assumed office and so the new president formed the Presidents Task Force on Immigration and Refugee Policy under status quo pressure. Suggestions by this task force would lead to the next three United States immigration policies: Immigration Reform and Control Act (IRCA) in 1986, the Immigration Act of 1990, and the Illegal Immigration Reform and Immigrant Responsibility Act of 1996. Policy Change

The employer sanction section of IRCA was destined to fail due to the implementation method of enforcement. Employers could use 14 different pieces of information to verify individual immigrants and complete the 1-9 INS form. Although there was a discussion of the possible implementation problems and thus a push to only use a Social Security card; fears of a national identity card infringing on individual rights of citizens stopped this way of enforcement. Using such a wide variety of documents allowed for false papers to more easily be made and accepted by employers as legal documents (Lanham, 2000). 
The effectiveness of IRCA has been of great debate since the late 1980s (Theodoulou \& Kofinish, 2004). A drop in undocumented migration was reported between the years of 1986 to 1989. Policy analysts attribute this not to new controls of IRCA but rather the amnesty portion of IRCA that lowered undocumented immigrants by 1.7 million. The lack of a single document, such as a Social Security card, has led to an increase in fraudulent documents and thus a decrease in enforcement against employers. Since 1994 , only $2 \%$ of INS resources have been allotted to workplace enforcement and $3 \%$ to suspected employer investigation. Specific IRCA research by Bean et al (1990) suggests that IRCA did not stop the flow of undocumented migrants and was unable to say whether it actually reduced numbers present in the United States. In addition, the characteristic changes of immigrants during the study time period (more female, less Mexican, and more children with mothers) has attributed to changes not expected by the formulation and implementation of IRCA. IRCA did allow 2.7 million documented immigrants to apply for relative visas (Graham, 2004).

Inclusion vs. Exclusion Level.

The Policy Response Continuum labels IRCA as a negative one. The increases in sanctions, both internal and external, increase the level of restriction for migrants not fitting within the narrow ranges of acceptable immigration (Timmer \& Williamson, 1998) (See Table 1.)

\section{Immigration Act of 1990}

The policy basics of the Immigration Act of 1990 are discussed followed by the implementation of CLEIM to this specific policy. The Immigration Act of 1990 established the United States Commission on Immigration Reform (USCIR). The act also lessened the number of entry questions centering on ideology (except for alleged Communists). A ten year ban on convicts of vice and prostitution started. Immigrants were now of the following categories: employment, family reunification, diversity, or lottery (Daniels, 2004). Family sponsored categories, by order of preference, included: unmarried son and daughters of United States' citizens, spouses/children of alien residents and unmarried son/daughters of alien residents (21 years and older), married sons/daughters of U.S. citizens (to include spouses and children), and brothers/sisters of U.S. citizens (Theodoulou \& Kofinis, 2004). According to Daniels (2004), the 
following new employment visas were created: $H, O, P, Q$, and R. (See Table 4.) Employment preferences by order of preference included: priority workers (extraordinary ability, multinationals, executives, managers, professionals); professionals with exceptional ability, skilled workers and other professionals; employees of U.S. missions in Hong Kong, religious workers, juvenile court dependents; and employment creation (Theodoulou \& Kofinis, 2004). Diversity visas were given to citizens of countries without large numbers residing in the United States. Most visas were given to Europeans. This type of visa is randomly awarded through mail in lottery. After the individual immigrant is established in the United States, he/she may apply for his/her family to migrate to the United States (DeSipio \& Garza, 1998).

Temporary Protected Status was established as a way to avoid deportation of an individual immigrant if suspected that returning to her/her homeland could be physically harmful (Churgin, 1996). The Attorney General could interfere with deportation to chaotic countries and allow individual immigrants to remain in the U.S. for 6 to 18 months. At the end of 18 months, the length of time could be extended to a Deferred Enforcement Departure. Countries targeted by Temporary Protected Status include: Kuwait, Lebanon, Liberia, Somalia, Rwanda, and Bosnia (Churgin, 1996).

\section{International Situation}

The early 1990 s witnessed massive change. Apartheid was eradicated in South Africa. The South African President, F.W. de Klerk, allowed the National African Congress to function. Nelson Mandela was released from prison by President Klerk. In Germany, the Berlin Wall was torn down and Germany began the long process of reunification. The Soviet Union collapsed and Gorbechev was elected as first executive president of the Soviet Union. Countries, such as Belarus, began the process of official independence from the Soviet Union. The first free presidential elections were held in Romania (Hingley, 2003).

\section{National Situation}

The 1990 s were known for an increase in anti-immigrant sentiment. American attitudes slowly evolved over time partially due to the media's influence on the average American's views (Chavez, 2001). As an example of this phenomenon, Chavez (2001) provides a link between 
magazine covers, the economic state, and negative beliefs toward immigration exhibited by magazine covers. During five depression times, economic worrisome magazine covers were almost immediately followed by a cover negatively portraying immigration. (See Table 5.)

Policies were written to obtain workers needed in specific areas of work (Daniels, 2004). An example of this is the 1990 Immigrant Nurses Relief Act in which nurses were actively recruited to work in the United States. Nurses already employed in the U.S. as temporary workers could apply to receive permanent alien status for up to 3 years of employment (Daniels, 2004).

The Gulf War (1991) was led by the United States, with many other nations taking part, to drive Iraqi forces out of Kuwait. Questions over United States motives as altruistic or oil seeking began to circulate throughout the world. This questioning would continue into future United States conflicts.

The European Union formed (1992) as a group of 25 countries under the Maastricht Treaty to have agreement on policy in the following areas: health, economic, foreign affairs, and defense. A single market currency was established between the member nations. A supranational European court superseded national courts of member countries (Shetsova, 1992).

\section{Influence Groups}

The Immigration Act of 1990 instituted and enforced the division between skilled and unskilled immigrants. As such, skilled immigrants were viewed by the status quo as competent workers. On the other hand, unskilled workers began to be viewed as substitute workers or competition for U.S. middle and lower class jobs. Focus on this belief created higher levels of negativity toward immigrants and immigration (Timmer \& Williamson, 1998).

\section{Policy Changers}

President Clinton's (1990-1998) initial support of policies to decrease the numbers of legal immigrants changed after an event sponsored by an Asian American club that raised $\$ 1.1$ million in campaign contributions to the Democratic national committee. The population of AsianAmericans might have been the most greatly effected by changes in family based immigration and as such this group banded together as an interest group to create a change in Clinton's view of proposed immigration policy decisions (Lanham, 2000). 
Inclusion vs. Exclusion Level

The Policy Response Continuum labels the Immigration Act of 1990 as a zero. Immigrants were still placed in categories for entrance now to include: employment, family reunification, diversity, or lottery. This policy did start Temporary Protected Status as a way to offer safety to immigrants, instead of deportation, to countries of known unrest (Timmer \& Williamson, 1998) (See Table 1.)

Violent Crimes Control and Law Enforcement Act (1994)

The Violent Crimes Control and Law Enforcement Act (VCCLEA) established a criminal alien center to focus on deportation, higher penalties for passport and visa violations, increase in external controls, and a new "S" visa. The " $S$ " visa is a non-immigrant visa that could be used to interrogate witnesses to terrorist activity (Daniels, 2004).

International Situation

President Clinton and the Russian President Yeltsin signed the Kremlin Accords. These accords centered on stopping the warehousing of preprogrammed nuclear weapons. As a result, nuclear arms were dismantled in the Ukraine area (Hingley, 2003).

National Situation

The mid-1990s climate was increasingly anti-immigrant, possibly due to actual changes in the economy and unemployment and media influence (Daniels, 2004). Media influences focused on the ineptitude of the INS and decreased controlling of the borders.

During the 1990 s, pressures mounted by the status quo as the public became increasingly verbal, via petitions, internet, and media coverage, to spread the message on beliefs of immigration (Graham, 2004). Proposition 187 was passed in 1994 in the state of California. Known as the "Save our State" act, this proposition virtually stopped all social service provisions to undocumented immigrants. Social services included emergency care, public school for children, food stamps, etcetera. Although soon overturned by the California Supreme Court, Proposition 187 provides a glimpse of the attitudes forming toward immigration throughout the country. In 1995, a commission on immigration reform, headed by Barbara Gordon, focused on the cost of benefits for immigrants, border security, ways to end chain migration, and the start of a 
new identification system. Gordon sought the expertise of four well known economist's and sociologist's opinions concerning the economic benefits/costs to immigration with the following results: Borjas found net gains to wealthy U.S. citizens and a decline in the skills of the workforce; Jencks found low numbers of skilled workers and losses of African American jobs; Glazer found an increase in equality of jobs, especially for African Americans; and Huntington found a lack of assimilation for new immigrants (Graham, 2004).

In January 1994, NAFTA (North American Free Trade Agreement) was based on the assumption that illegal immigration is derived from economic integration of the Western Hemisphere. It was expected that promoting economic connections and jobs in Mexico and Canada would decreased the numbers of undocumented migrants (Graham, 2004).

Although California Proposition 187 was struck down, Daniels (2004) asserts that political ramifications are noted in other policies implemented soon after. The Antiterrorism and Effective Death Penalty Act (April 24, 1996) decreased legal protections for un-naturalized legal immigrants. It is believed, in addition to Proposition 187 , that the Oklahoma City and $1^{\text {st }}$ World Trade Center Bombing influenced the passage of this bill. The Personal Responsibility and Work Opportunity Reconciliation Act (1996) and the Illegal Immigration Reform and Immigrant Responsibility Act (1996) were also highly influenced.

\section{Influence Groups}

A portion of the population started to focus on the negative aspects of change within the United States. Many purporting a conservative view focused on the issue of family values as the center piece of change within the country. If the United States could return to a focus centered on family values, then positive changes could take place within the country. Debates on topics such as censorship, religion in schools, premarital sex, contraception, and abortion lined up strong sentiment on both sides of these controversial issues.

\section{Inclusion vs. Exclusion Level}

The Policy Response Continuum labels the Violent Crimes Control and Law Enforcement Act (VCCLEA) as a negative one. The focus on criminalization of undocumented migration, the 
start of an alien crime center, and the more critical focus on visa and passport documentation is a more restrictive policy of immigration control (Timmer \& Williamson, 1998). (See Table 1.)

Illegal Immigrant Reform and Immigration Responsibility Act (1996)

The policy basics of the Illegal Immigrant Reform and Immigration Responsibility Act are discussed followed by the implementation of CLEIM to this specific policy. Soon after the passage of welfare reform in the United States, this act, an immigration specific policy entitled the Illegal Immigrant Reform and Immigration Responsibility Act (1996) was passed. IIRIRA increased enforcement of both internal and external controls and increased the standard of the amount of money needed for admissions of sponsored legal immigrants. External controls included immigrant monetary penalty for false documents of $\$ 250$ for first fine, higher penalties for "alien smuggling" (wire tap use allowed), and examination of new ways to track visa over-stayers violators (p.776). Internal controls included more staff for the detection of undocumented migrants, more attempts to federalize identification cards, and more money for IDENT program that fingerprints all criminal aliens (both law breaking and just undocumented).

\section{National Situation}

At a similar time in 1996, the passage of the Personal Responsibility and Work Opportunity and Reconciliation Act (1996) created changes in the implementation of welfare for citizens and non-citizens alike. This act created limitations on immigrant access to welfare payments and social services including means tested programs such as AFDC, Medicaid, and state/local program such as food stamps, and SSI (Espenshade et al., 1997).

With the conservative nature of the United States increasing a precedent setting civil rights court case was heard in the Colorado Supreme Court. In Romer vs. Evans, the Colorado Supreme Court ruled against a law that would protect homosexuals against discrimination based solely on sexual orientation.

The Olympic park bombing in Atlanta, GA during the 1996 Summer Olympics increased fears of terrorism in the United States. Issues concerning safety for American citizens were of concern. This type of terror activity is pointed to as an example of what happens without strong homeland security policies. 


\section{International Situation}

The United State's homeland security concerns are further complicated by world wide safety concerns. In March 1996, Iraq refused to allow investigators from the United Nations Special Commission (UNSCOM) to enter five sites designated for inspection. Regular site inspection was agreed upon by both Iraq and the United Nation's Security Council post Desert Storm (1991). As Iraq continued to refuse to cooperate, the United States attempted, without success, to gather support for military action by the U.N. Security Council (Wikipedia, 2006).

As the Middle Eastern instability increased, the Taliban regime forcefully gained control of Afghanistan after ousting President Rabbani on September 27, 1996 (Wiikipedia, 2006).

\section{Influence Groups}

Rick Schwartz, a pro-immigrant lobbyist in Washington, helped to form the National Immigration Forum. This interest group advocates for increases in government sanctioned forms of migration. Schwartz, along with the support of the National Immigration Forum, helped to lobby the removal of legal migration changes initially proposed in IIRIRA policy. Inadvertently, this further increased attention on undocumented migration (Lanham, 2000).

Continued domination of conservative groups focused on topics such as immigration, abortion, gay rights, and the death penalty. An example is the attempt of a local Philadelphia group to push through the Community Decency Act that would prohibit indecency on the internet. A panel of federal judges did block this law due to the U.S. right to freedom of speech, but this provides a view of $21^{\text {st }}$ century status quo views.

\section{Policy Changers}

President George W. Bush (2000-present) was the Governor of Texas previous to assuming the presidency. During his campaign, Bush labeled himself a "compassionate conservative" in his change approach. Bush supported education vouchers, the use of private religious organization to deliver services, and structural changes to the military. The world trade center catastrophe occurred resulting in the focus, of the Bush presidency and the United States, on the "war on terror". Bush won a second term in the presidency against John Kerry in 2004. 
Much controversy continues to surround the war in Iraq and whether to continue or to exit the current situation.

Policy Change

Unintended consequences included an increase in illegal migration (especially unskilled) and an increase in the pressure for naturalization. Increasing numbers of naturalized citizens, translated into less monetary savings than anticipated by political changes (Espenshade et al., 1997).

Inclusion vs. Exclusion Level

The Policy Response Continuum labels the Illegal Immigration Reform and Immigration Reform Act as a negative one due to further criminalizing undocumented status (Timmer \& Williamson, 1998) (See Table 1.)

Changes around September 11, 2001

Previous to September 11, 2001, United State's President George W. Bush states the following about immigration:

The United States is a nation of immigrants. Unfortunately, today when new immigrants arrive on our shores, their first exposure is often one of frustration and anxiety. The administration believes that legal immigration should be greeted with open arms, rather than endless lines. We must be responsive to those who have emigrated and now seeks to become U.S. citizens (Daniels, 2004, p.263).

Although a policy of amnesty was being discussed between Vicente Fox, the president of Mexico, and George W. Bush the September 11, 2001 world trade center attack shifted the U.S. focus from inclusion to exclusion through more stringent border control and internal controls. Worries concerning homeland security promoted changes in large sections of U.S. policy including immigration policy, national security, government organization, priorities, travel, and identification for citizens (Graham, 2004).

Non-Immigrant Visas

Changes in immigration policy stemmed from knowledge gained during the September $11^{\text {th }}$ investigations that suggested easy entrance of terrorists into the U.S. through the current INS 
system (Graham, 2004). More specifically, differences between immigrant visas (IV) and nonimmigrant visas (NIV) were of great concern. NIVs include visitors, tourists, business people, students, and temporary workers. Several of the men involved in 9/11 were student visa overstayers and so the connection was made between undocumented immigrants and NIVs. In particular, the F-1 visa, a student visa, had little checks and balances leading to two risky factors: ability to over stay a student visa without much difficulty and the high technical knowledge of those with student visas (Graham, 2004). Fear and concern led to the following post- 9/11 policy considerations: (a) creating a student and exchange visitor tracking program (H.R. 3205, S. 1618), requiring background checks for incoming foreign students (H.R. 3239), prohibiting student visas to individuals from a nation-state of suspected terrorism (S. 1627), and placing a moratorium on the insurance of all visas to nonimmigrant students (H.R. 322) (Theodoulou \& Kofinis, 2004).

\section{A Different Use for Immigration Law}

Safety concerns enabled immigration law to be used to detain, hold, and refuse council of migrants based solely on national origin (Daniels, 2004). The Department of Justice Inspector General, Glenn A. Fire, investigated this issue and found that within the twenty months after $9 / 11$, a total of 762 people were held and interrogated only to be later released with no proof of involvement in the terrorist attacks.

\section{U.S. Patriot Act (2001)}

The first post September $11^{\text {th }}$ act, passed to ensure U.S. safety, is commonly called the United States Patriot Act (2001). The United States Patriot Act (2001), officially titled "the Uniting and Strengthening America by Providing Appropriate Tools Required to intercept and Obstruct Terrorism Act", enhanced the ability of U.S. law to intercede in an attempt to stop possible forms of terrorism (Theodoulou \& Kofinis, 2004, p.292). Laws amended include: immigration policy, banking and money laundering, and foreign intelligence. Parts applicable to immigration policy include the ability to detain migrants considered "a national security risk" for up to 6 months without legal council (p.292). In addition, a foreign student monitoring program was put in place to increase safety of this visa program. 
The INS was targeted as one of the main factors contributing to the disastrous September $11^{\text {th }}$ events. As a result, the Homeland Security Act (2002) abolished the INS. The new service to handle both immigration and naturalization would be housed under the newly formed Department of Homeland Security (DHS). In the past, the INS was a single service that focused on both enforcement and service. Under the new DHS, enforcement and service will be completely divided. This change could lead to increased efficiency or enforcement receiving higher attention and money than service (Theodoulou \& Kofinish, 2004).

The three new bureaus under the DHS to handle enforcement and service include: the Bureau of Customs and Border Protection (BCBP), the Bureau of Immigration and Customs Enforcement (BICE), and the Bureau of Citizenship and Immigration Services (BCIS). The first director of the Bureau of Immigration and Customs Enforcement on March 2003 was Michael Garcia, a formal Federal prosecutor (Daniels, 2004).

The previous INS commissioner, James W. Ziglar, expressed his concern over the new structure of the DHS:

While this focus on national security is appropriate and wise, there is also a continued need for immigration officers in the Department of Homeland Security to maintain, and even strengthen, the INS' traditional service function. Indeed, the DHS should consider taking advantage of the opportunity to begin to dialogue on our immigration policy and find new ways to better assimilate immigrants into our culture. This will not be easy, and it is not a natural fit for this new department. The law creating the DHS spells out its mission in security in great detail but the role this agency plays in service to immigrants and visitors- a role that helps to boost our economy, enrich our culture, and secure our moral standing in the world- is barely mentioned (Daniels, p.264, 2004).

Trigger Event

The trigger event for the Homeland Security Act (2002) centered on the event known as 9/11. On September 11, 2001 the largest terrorist attack on United States soil transpired, in which planes crashed into the twin towers in New York City. The U.S. and the world watched the video 
clips again and again, unable to believe the death and destruction that had callously been plotted. As a result of the fear associated with the $9 / 11$ attack, a series of events transpired in an attempt to keep the United States safe from future destruction. Policy makes quickly made decisions based on "homeland security" rather than sound analysis of the actions that would best seek the true solution for safety.

To further understand the effect of September $11^{\text {th }}$ on United States policy, an examination of causality, severity, incidence, proximity, and crisis must be explored (Theodoulou \& Kofonis, 2004). Causality was attributed to Muslim extremists led by Osama Bin Laden and, as a result, fears concerning people of Muslim faith and Middle Eastern looks were deemed "outsiders". The severity of both monetary value and loss of life was high. The incidents were moderate due to more than one attack occurring on the same day: trade towers, pentagon, and a Pennsylvania field. Due to the attack being the closest large magnitude terrorist attack in United States history since WWII's attack on Pearl Harbor. Proximity was also high. The combination of the high severity, close proximity, and multiple incidents led to a high crisis level.

\section{International Situation}

On an international level during the year 2002, the following occurred: (a) the largest expansion of NATO occurred to now include: Bulgaria, Estonia, Latvia, Lithuania, Slovakia, and Slovenia; (b) on March 11, 2004, Madrid, Spain had train bombings in which a terrorist cell was responsible; (c) Iraqi hearings began against Saddam Hussein for war crimes (June 30, 2004); and (d) Chechen rebels took hostages to demand the independence of Chechnya from Russia. This hostage situation was settled by the invasion of Russian forces, killing approximately 335 people and injuring 700 more (Hingley, 2003).

\section{National Situation}

In the United States, other changes were taking place besides the intense focus on homeland security. As a step toward equal rights, San Francisco conducted same sex marriage ceremonies. Massachusetts followed suit and legalized same sex marriage as a result of a State Supreme Court's ruling in Goodridge vs. Department of Public Health (Wikipedia, 2006). 
The United States continued to dominate as an economic world power. As an example the U.S. lifted the almost 30 year ban against Libya (Daniels, 2004).

Influence Groups

The $21^{\text {st }}$ century has noted a large split between conservative and liberal camps. With continuing control over the house, senate, and the presidency, conservatives are in a position to influence changes in the United States. Liberals continue to attempt change through various means such as petitions, rallies, and protests.

Inclusion vs. Exclusion Level

The Policy Response Continuum does not apply to the Homeland Security Act per se since this policy rearranged the department that oversees immigration rather than changing policy for migrants specifically. The treatment of migrants and the changes in policy in the next five to ten years will help to understand the changes brought about by the Homeland Security Act.

\section{Current Immigration Policy Problems}

As the United States continues to grow as a country of immigrants, concerns of migration have continued to evolve over time. Current and future U.S. immigration policy concerns are the following: (a) high numbers of low skilled workers, (b) increasing U.S. need of skilled workers, (c) need to examine family based visas due to high levels of dependency, low levels of education, and low levels of skill, and (d) ways to restrict numbers to encourage meeting U.S. needs (Lanham, 2000).

Graham (2004) suggests that our country is currently undergoing a struggle between multiculturalism versus factionalism as evidenced by the division of ethnicities by region of the country. The racial breakdown of the U.S. by regions entails: Northeast largely Jewish, South largely African American, Florida largely Cuban and Haitian, West Coast largely Asian, Northwest mostly European, the Southwest largely Hispanic, Alaska mainly environmentalists, Hawaii mainly Japanese, the Middle South western states Native American, and the Rocky Mountain Region area Mormon. Daniels (2004) suggests further examining this divide by exploring the connection between United States immigration policy and attitudes toward immigrants throughout 
history to better understand the United State's future attitudes that will impinge on policy. (See Table 6.)

"Very process by which immigration policy develops, a political policy process that does not necessarily seek or result in the best policy, helps sow the seeds of future policy failure" (Theodoulou \& Kofinis, 2004, p.298). 


\section{CHAPTER III}

\section{APPLICATION OF CAPPICCIE LAWSON EVOLUTION IMMIGRATION POLICY \\ MODEL TO GERMANY}

"Massive immigration is a relatively new challenge that calls into question, to a considerable extent, Germany's self identity as a mono-cultural entity with national and ethnic character development over centuries in sharp differentiation from those of other nations" (Monar, 1997, p.58).

German history is unique due to the mass movement of peoples with different cultural backgrounds throughout history; thus allowing for the native descendents of Germany to be a compilation of ethnic minorities (Bade \& Weiner, 1997). Over three million ethnic German citizens have lived for years outside of the borders of present day Germany; thus "little Germanies" have been developed throughout the world. Due to changing borders and migration of people, Germany has experienced emigration, immigration, and transient movement of peoples.

Discussion centering on the inclusion and exclusion of peoples is complicated by the past human rights abuses of the Nazi regime (Bade \& Weiner, 1997).

This chapter will begin with explaining the specialized concept of German Citizenship. Understanding the view of citizenship is important due to the influence of this concept on the inclusion versus exclusion of migrants. An overview of the German Government organization will follow to provide a basis for construction of immigration law. A discussion of the term law versus policy will be explained. A description of the most foreign populated areas of Germany will be discussed to provide a "portrait" of current immigration. The majority of this chapter will provide an overview of the periods of immigration and immigration law throughout the history of Germany. After exploring the basics of Germany's migration history, an analysis of the most pertinent immigration law from post World War II until the present will be performed by applying the 
Cappiccie Lawson Evolution Immigration Policy Model (CLEIM) to each specific immigration law (See Figure 1.) The application of CLEIM to each German policy will begin to answer the research questions pertaining to the accuracy of the model (\#5), the role of influence groups (\#1), the role of policy changers (\#2), the role of events (\#3), and the use of applying the Policy Response Continuum (\#6). If an important historical event occurred between the discussed immigration policies, this information will be provided in sections of the chapter marked as "Historical Context between Immigration Policies".

\section{The German Concept of Citizenship}

"Given high migration, ethnic diversity, and political disunity, the answer to the question of who was a German emphasized language, culture, and ethnic background" (Teitelbaum \& Winter, 1998, p.14).

World-wide decisions of citizenship are based on two categories: jus sanguinis or jus soli. Jus sanguinis is "citizenship based on descent" and jus soli is "citizenship derived from place of birth" (Marshall, 2000, p.139). Germany bases the idea of citizenship on the concept of jus sanguinis; thus having a strict notion of citizenship and naturalization (Munz \& Ulrich, 1997). The Nationality Law, part of the Constitution (Grundgesetz), first mentions naturalization in section 8 of the 1913 Nationality Act (Neuman, 1998). The 1913 Law was based on Prussian legislation and based on inclusive notions to include all Germans even those living outside of national borders (Marshall, 2000).

Germany's notion of citizenship was further formulated by national guidelines in 1977 (Neuman, 1998). In order to apply for naturalization, the individual must have a good grasp of the German language, government structures, permanent housing, deemed morally sound, have 10 years of residence, and shown to embrace the culture. Section 86 , of the national guidelines, addresses guest workers in which 15 years of residence must have occurred before application. Article 116 discussed the distinction between citizens and nationals. In 1993, a change in the Foreigners Law (Auslandergesetz) created easier naturalization for those residing in Germany for 15 years and for children of foreigners from 16 to 25 who have lived in Germany more than eight years (Munz \& Ulricht, 1997). 


\section{The Formation of the German Government}

In 1871,26 states formed the German nation state. Over time the land mass increased or decreased depending on the ideas of the ruling government. At the end of World War II, eleven states were part of West Germany and five states were part of East Germany. At the time of reunification (1990), these sixteen states formed as a unified Germany (Turk, 1999).

Germany has had written law since the time of Roman law (Turk, 1999). After World War II, East and West Germany had separate legal codes. During reunification, the legal codes of East and West Germany merged. The Federal Constitutional Court (Karlsruche) is composed of two panels with eight judges each. Half of the judges are from the Bundestag (Federal level) and half from the Bundesrat (State level). Under the Federal Court is the Federal Court of Justice composed of 4 federal jurisdictions: administrative, financial, labor, and social. Below this are the regional court system and lastly the local court system. The state legislation (Landtag) is responsible for implementing Federal legislation such as social welfare provision, higher education, law enforcement, and regional planning. Throughout history, local governments have been responsible for cultural facilities, local transportation, taxation, and addressing educational and cultural concerns (Turk, 1999).

The official name of the unified Germany is the Federal Republic of Germany (FRG) or the Bundesrepublik Deutschland (Turk, 1999). The Constitution, known as the Basic Law, was ratified on May 23, 1949 by West Germany. In 1990, the unification treaty adopted the Basic Law as the Constitution of the FRG. The sections of the Basic Law are as follows: Section I (19 articles of Civil Rights), Section II (Federal and States), Section III (Bundestag), Section IV (Bundesrat), Section V (Federal Presidency), Section VI (Federal Government), Section VII (Federal Legislation), Section VIII (Execution of Federal Law), Section IX (Judicial), and Section X (Finance).

Law is the basis of German immigration decisions due to this country's emphasis on determining rights and responsibilities from the Basic Law codes. German legal experts suggest that this black and white way of ruling is a result of the past abuses by the Nazi party. By providing all rights and responsibilities in one specific section of the code, undue influence by 
particular parities in power could not sway the agreed upon rules. In addition, Germany refused to be considered a country of immigration and as a result did not pass an official immigration policy until 2004. Before this policy, all rules and regulations for immigration were considered law.

German rules believed that passing an official immigration policy, versus law, would announce to the world that Germany was in fact a country of open immigration; thus resulting in a large influx of migrants. By keeping immigration decisions in the form of law, it was hoped that the number of migrants would remain low. This was not in fact the case and as such the first immigration law was implemented in 2004. More will be discussed on this topic later.

\section{Current Settlement of Migrants within the German States}

A portrait of current German migration shows approximately $75 \%$ of all current migrants to Germany living in four states (sections of Germany): Baden-Württemberg (Southwest), Bavaria (Southeast), Hesse (central), and North Rhine-Westphalia (West). The cities that have the largest numbers of migrants are Frankfurt (27.9\%), Stuttgart (23.3\%), and Munich (22.3\%) (Munz \& Ulricht, 1997). (See Figure 2.)

The State of Hesse

The state of Hesse's capital is Frankfurt (Buse, 2005). Frankfurt, and thus the Hesse, is fondly known as the banking capital of Germany. Estimates of 6 million or $10 \%$ of residents are foreigners. This area of Germany had a large Jewish community that was virtually destroyed during World War II. After WWII, the rise of political parties of Social Democrats and Christian Democratic Union should be noted. During the 1950 s and 1960 s foreign labor was perhaps drawn to this area due to work available on the assembly lines. Most of the jobs are in the banking, car manufacturing, chemical, and drug manufacturing trade. Frankfurt is a central transportation hub both for air and trains for central Europe (Buse, 2005).

\section{The State of Bavaria}

Bavaria is $2 / 3$ Catholic and thus is steeped in conservative ideas, folklore, and tradition (Buse, 2005). Only a small pocket of Protestants are noted in the North of this state. Since 1960, influence has strengthened from the conservative Christian Society Union. Bavaria is the largest 
state with 12.1 million inhabitants, of which $10 \%$ are foreign. Bavaria has the largest number of universities, the lowest rate of welfare use, and the lowest rate of unemployment.

Within the state of Bavaria, much internal migration is noted into the city of Munich. The past history of influence by the Celts, Romans, and Eastern tribes has led to 3 main groups of settlers: Bavarians (South), Swabians and Allemanen (Southwest), Franks (Northwest), and some suggest a fourth group after World War II, the Sudenten Germans from Bohemia. Cultural importance was first noted by King Ludwig II and was maintained possibly due to the independent nature of Bavaria. In 1918, the people overthrew the Wittelbach rulers and claimed Bavaria a Free State (freistaat). This independence led to bloody battles between the national government and the Bavarian state government. The unhappiness of these battles led to civic unrest and a breeding ground for extremist groups such as the Nazi party. In 1923, Hitler attempted to seize power in the Beer Hall Putsch but failed. Further Nazi propaganda did occur with occasional speeches held in Nuremburg. Initially the Catholic Church cooperated with the Nazi rule but after realizing the details of the party's beliefs the association decreased in the $1930 \mathrm{~s}$. The first denial of basic civil rights was noted in the Nuremberg Laws of 1935 in which anyone not of Aryan race was denied citizenship (Buse, 2005).

\section{The State of Baden-Württemberg}

Baden-Württemberg is part of the Romantic road of Germany and thus is intricately bound to old customs (Buse, 2005). The villages are part of the history of this state while the cities are new and modern due to the rebuilding after World War II. The old state of Baden was mostly Catholic and Württemberg was mostly Protestant. These two states were united in 1952 despite such religious differences. Baden-Württemberg is the $3 r d$ largest state with a population of 10.1 million of which 1.3 million are foreigners. Stuttgart is the capital city. Large employers include Daimler/Chrysler, prisons, service industries, universities and technical colleges. Other cities include Mannheim (63,000), Freiberg im Breisgau (15\% foreign), Old Heidelberg, Pforzheim, and Karlsruhe. The strength of families and corporation monies has led to the start of numerous foundations devoted to research, education, and cultural diversity. Industries include automobiles, agriculture (grains, hops, and grapes), and tourism. 


\section{The State of North Rhine-Westphalia}

North Rhine-Westphalia is on the northwest bordering the Netherlands and has a total of 18 million residents of which $10 \%$ are foreign. Twenty percent of the inhabitants of this region live in cities. Industry centers around mining, steal, and coal. Boundaries of this area have changed frequently between France, Germany, and Belgium. At times, battles between Catholics and Protestants have been heated. Movements throughout the state have been to follow jobs. From 1891 to 1905 large numbers of unions were formed due to the high level of industry. Strikes were successful in earning more rights for workers. During WWI, much of the machinery needed was produced in this area. Unions were successful in gaining better work day hours, better working conditions, and higher protections for female and child workers. Secret groups formed during the Nazi reign of power due to the attempts by Hitler to break labor unions. North Rhine-Westphalia received the most allied bombing during WWII due to the nature of being the industry machine for the war. High economic problems were noted during the oil crisis of 1973 . The 1980 s required subsidies from the Federal government to ailing plants. This region is known for rebuilding (both literally and figuratively) after the hardships of WWII. Currently, North Rhine-Westphalia is responsible for $20 \%$ of Germany's production of food processing, chemicals, automobiles, and electricity. Unemployment is noted in most major cities due to losing jobs to third world countries

\section{Overview of German Migration Periods}

Overall, three periods have arisen in relation to ethnic German feelings toward foreigners (Bade \& Weiner, 1997). The first period, the early $19^{\text {th }}$ Century, focuses on the foreigners as a nationalistic or romantic (Volkisch-Romantisch) notion of the other. During the late $19^{\text {th }}$ and early $20^{\text {th }}$ century, an overriding ethnocentristic view evolved into negative feelings against those considered alien (Fremdartigkeit). The mid $20^{\text {th }}$ century was noted for the rise of Nazi power and the destruction of "culturally foreign stock" (artfremde) (p.2). After World War II, the focus of migration has evolved through a set of laws put into place to mandate restriction for entrance, employment, social service provision, individual rights, and the naturalization process (Bade \& Weiner, 1997). Germany refused to be an open country of immigration and as such did not have an official immigration policy until late 2004 but rather a set of laws meant to address increasing 
numbers of migrants. The long term effects of the only official German immigration policy are yet to be determined (Green, 2005).

\section{The Beginnings of Migration until the Early $19^{\text {th }}$ Century}

During Germany's first period of migration, the early settlers to this area were named the Germari by the Celts (Turk, 1999).The Germari, composed of migrant tribes, roamed the Eastern banks of the Rhine. Over time, more permanent settlements were established and villages were formed around the concept of a town hall for socialization. The beginning of Western Europe's official division into a system of Germanic kingdoms and confederations occurred in 493 and shortly thereafter Germany converted to Catholicism (Turk, 1999).

The embracing of the Catholic faith would become a center point for the migration of peoples into and out of the German territory (Turk, 1999). The ruling dynasties (the Carolingian, Ottonian, Salian, Hohenstaufen, and Hapsburg) continued this tradition of dividing people according to faith until the time of the reformation. During the reformation, the struggle between Catholicism and Protestantism waged until the 30 Years War (1618-1648) which ended with the Treaty of Westphalia. This treaty established the idea of the sovereign state as a decision maker over the territory rather than the divided church.

\section{The History of Late $19^{\text {th }}$ Century until World War I}

The $2^{\text {nd }}$ period of migration coincided with the second German Empire. This empire constructed in a far different manner than the previous ruling parties. The people in power had the ability to determine rulers of this time period rather than the popular vote by the empire (Turk, 1999). The King of Prussia, the emperor of this land by heredity, appointed people to both the position of chancellor and governmental ministers. With this new government structure, the new Chancellor and the new ministers would not have a responsibility to follow the legislature's (Reichstag) decrees (Turk, 1999).

The poor German economy pushed many German migrants to immigrate to the United States from the 1820s-1850s (Daniels, 2004). Most Germans traveled to the U.S. in hopes of obtaining land. The strong sense of German culture remained upon arrival in the U.S. Germans 
formed what has been termed the "German Triangle" due to large numbers settling in St. Louis, Cincinnati, and Milwaukee (p.10).

\section{Social Service Provision}

For those Germans that refused to migrate, an increase in social and economic difficulties developed from the old structure of the political system (Turk, 1999). This difficulty was compounded by the control of the state legislatures by the wealthy. Dissension grew as decisions were made for the elite few rather than the masses. As a result of the tension, political parties developed leading to the great cultural struggle (Kulturkampf). Through this struggle the German economy swelled leading to a series of programs developed to support workers: workers welfare program (1883), sickness insurance (1883), accident insurance (1884), and old age insurance (1889).

\section{A Guest Worker Program Established}

During the 1880 s and 1890 s, labor concerns centering on migration continued to rise (Bade \& Weiner, 1997). German employers required inexpensive labor from across the Eastern border in Poland. The German Government feared that increasing numbers of foreign labor might create difficulty for individuals with Polish ancestry (Ruhr Poles) as the Ruhr Poles were the largest ethnic minority in Russia during that time period. To help reduce worries, the government agreed to use a rotation system of seasonal labor in which numbers of migrants would increase in the spring and summer to help with farming needs and then virtually disappear during the fall and winter months. The start of this program began the first official guest worker program using a Polish labor force.

\section{Migration Increases}

After the creation of a guest worker program, numbers of migrants continued to enter Germany from 1880-1913. The majority of migrants to Germany were ethnic Poles from Russia and Austro-Hungary (Fetzer, 2000). A large majority of these migrants were of Jewish faith. The German faith base still remained mostly Protestant and Catholic (depending on the area of Germany). High levels of nativism were noted toward Polish migrants; especially Polish Jews. Poles were forced to live in poorer housing and suffered from higher levels of physical and verbal 
abuse. The term "Pollack" was a racial slang term used to describe this group. Negativity toward Jewish Poles culminated in an 1881 petition to deny immigration to Germany by Polish Jews. Although this 250,000 signature petition failed, the feelings solidified the German concept of citizenship based on the notion of jus sanguinis (citizenship based on blood ancestry).

The Western part of Germany increased restriction of immigrant labor based on worries of Polish migrants flocking to jobs in the western steel and coal industries (Bade \& Weiner, 1997). The German Defense Policy was formed as a way to control the numbers of immigrants. It is important to note that this policy only restricted the number of Polish migrants and not those from other countries (i.e. Italians, French, ect.). During the power of the Weimar Republic, the number of migrant workers depended on the specific work needs based on the License Requirement Policy (genehmigungspflicht). After the number needed was ascertained, that specific number was given permission to enter the country. The Genehmigungspflicht system was used up until and throughout World War I.

While many migrants were entering Germany some German citizens were choosing to leave the country (Daniels, 2004). The combination of increasing nativist beliefs, the movement from rural to urban living, crop failure, drought, disease, and an outbreak of cholera all contributed to emigration from 1871-1914. Numbers of Southern and Eastern Germans migrated to the United States in hopes of following previous ancestors' success in a new land.

\section{World War I}

During World War I, Germany refused to allow foreign workers currently in the country to return to his/her homeland (Fetzer, 2000). These individuals, mostly Russian Poles, were forced to fill labor market gaps as well as to replace jobs of soldiers killed in the war. In addition to these migrants, approximately two million prisoners of war from Russia, France, and England were used as workers during this time period. High nativist attitudes led to hostility and abuse. Citizens became angry of the abuses of Belgian citizens and as such protested this treatment. Other types of migrants forced to live and work in Germany were not offered the same protections by the status quo as the protected Belgians. 
Armistice was declared on November 11, 1918 and the Treaty of Versailles was ratified on July 7, 1919 by the League of Nations (Turk, 1999). Decisions made by the Treaty of Versailles reshaped the German borders; leaving numbers of ethnic Germans living in the areas of Poland, Czechoslovakia, Yugoslavia, Romania, France, and Italy (Munz \& Ohlinger, 1998). The loss of such large tracks of land led to an increased desire for more living space (lebensraum).

From 1919-1923, 1.3 million ethnic Germans migrated to within the new German borders. Many of these migrants were administrative officials such as military, educators, and railroad personnel (Turk, 1999).

\section{Post World War I until World War II}

The Weimar Republic of Germany would survive through three distinct periods: a period of crisis (1920-1923), a period of domination and internal rehabilitation (1924-1929), and a period of depression (1929-1932) (Turk, 1999).

During the period of 1919-1932, negative attitudes toward the Polish continued (Fetzer, 2000). Anger focused on separation of Polish into ethnic enclaves. The eastern border to Poland was officially closed in 1932. While nativist anger continued against Polish migrants, Germany allowed 300,000 Russians to migrate due to the Russian Revolution without much restriction on this particular group.

Hitler started proselytizing his beliefs with speeches aimed at denouncing the Treaty of Versailles and the Weimar Republic (Turk, 1999). On November 9, 1923, Hitler attempted to seize power in Munich, Germany in what is known as the Beer Hall Putsch. He was unsuccessful in gaining power and was sentenced to 5 years in prison. While only serving a total of 9 months, Hitler wrote Mein Kampf. After his release, Hitler was successful in merging his hatred into a national movement with the help of Alfred Hugengerg, an owner of a popular newspaper with editorial space for sale. While using advertising to gain support, Hitler organized the Nazi party into districts (Gaus) and formed a Para-military called the Storm Troops to help "enforce" the message. 
On January 30, 1933 Hitler was named Chancellor and by March 23rd the Enabling Act gave Hitler dictatorship powers until April 1 of 1937.The deciaration of Germany as a state of emergency allowed Hitler to suspend civil liberties and set up his own cabinet (Turk, 1999).

The following laws were passed in the early years of Hitler's power: Civil Service Law of 1933- in which non-Aryans were identified and could have employment terminated; Religious regulation- protestant churches were combined in a new Evangelical church; and a treaty with Catholic churches which allowed for freedom with the agreement of no political speeches. As these new laws were passed, Hitler promised to protect members of the Nazi party living outside of the geographical borders of the Third Reich (Turk, 1999).

Increased desire for living space (Lebensraum) led to policy forcing Jews from rural to urban ghetto areas to free space for other Germans to live in the countryside (Wikipedia, 2006). Hitler devised a plan to eventually relocate the entire Jewish population of Europe to a French island off the coast of Southeast Africa called Madagascar. To pay for the move, the European bank would liquidate Jewish assets and the SS would govern this new state. This plan did not come to fruition due to the length and cost of the war. Instead, work and death camps would later form to remove the Jews.

Removal of political enemies was of utmost importance to the Third Reich (Turk, 1999). Starting in 1933, the State Secret Policy (SS or Gestapo) forcibly captured enemies of the state to place them into custody within forced labor camps. Dachau was the first labor camp which was later to be used as the model for future work and death camps. On June 30,1934 , the Night of the Long Knives, Hitler used the SS to purge Germany of 1000 rivals within the Nazi party. Removal of those in disagreement allowed Hitler to work towards his specific goals: rearmament of Germany, German world domination, self-sufficiency, and indoctrination of workers (as found in Mein Kampf). As World War II drew new, the focus of concentration camps was on those people of Slavic and Polish ancestry due to Hitler's belief in the inferior nature of these populations. The Slavic and Polish lands were seized to use as new living space (Lebensraum) for the future growth of the German population (Turk, 1999). 
The increase in killings by death camps pushed Jewish people to form different ways to move to places of safety such as the Youth Aliya (1933), the Central Office for Jewish Emigration (1938), and the Kindertransport (1938) (Wikipedia, 2006). The Youth Aliya, founded by Recha Freier, assisted 22,000 Jewish children to emigrate to Israel. In Vienna, Jewish residence formed the Central Office for Jewish Emigration. The goal of this group was to force migration of Jews from Germany to safe zone countries. Rich Jews would finance poor Jews in this endeavor. The organization would be staffed entirely by Jews within Germany to assist in promoting the prompt emigration from Germany. Some Jews did safely escape Germany using this route, but unfortunately the movement did not move as quickly as Nazi work and death camps. The Kindertransport, from December 1938- September 1939, removed approximately 10,000 children from Nazi occupied Germany, Austria, and Czechoslovakia to British foster homes. This project was supposed to eventually re-emigrate the children back to homelands. At the end of WWII, some of the foster children were able to return home but others lost home and family due to the war (Wikipedia, 2006).

Between 1938 and 1945, death camps killed approximately $2 / 3$ of the European Jews as well as gypsies, gays, prisoners of war, intellectuals, Jehovah's Witnesses, and the physically/emotionally disabled (Turk, 1999).

During World War II, the use of migrant workers was replaced by the use of the undesirables and prisoners of war as workers (Bade \& Weiner, 1997). Not using foreign labor was called the "deployment of foreigners" or Auslandereinsatz (p.12). Forced laborers of this time period experienced starvation, punishment, and horrid work conditions (Fetzer, 2000). A large number of the workers during World War II would become displaced persons at the end of the war (Bade \& Weiner, 1997).

On May 7, 1945, Germany surrendered. Germany was divided into 4 zones of occupation: the center of Berlin and East to Russia, Northwest to England, Southwest to the United States, and West to the French. Although the process of rebuilding in Germany was to be slow, the start of the Cold War led to turning Germany over to her own devises more quickly than expected. 
As of May 1945, from 7-11 million displaced persons (DP) were within German boundaries (Daniels, 2004). Although some of the DP returned to their own homelands others did not have places which to return. By Fall of 1945, 2 million DP remained. Negativity increased against this group both by Germans and allied forces. Pressure was placed on DP of Jewish decent to move to Israel. Although some people of Jewish faith did migrate to Israel others wanted to remain in Europe. Of those that remained, the deplorable living conditions within DP camps led to the United State's Truman directive of December 1945 to provide supplies. Supplies were funneled through agencies deemed competent such as the National Refugee Service. Volunteer agency involvement helped to improve the DP standard of living and thus this involvement set the precedent for Volunteer Social Service Agencies (VOLAGS) providing services to immigrants and refugees.

By April 1949, the English, French, and United States sector (Trizonia) was formed. The Truman Doctrine was a philosophy in which the U.S. would support any country attempting to ward off Communism. Thus the Trizonia, through the Marshall Plan, gave funds for rebuilding Western Germany. September 1949, the new government of West Germany formed the German Federal Republic (GFR). October 7, 1949, Russia authorized the formation of East Germany into the German Democratic Republic (GDR).

\section{Postwar World War II Migration: The Official Start of Law Concerning German Migration}

The decision to make migration decisions, post WWII, were mainly due to fear of the high numbers of migrants left after the war as displaced persons (Herbert, 1990).This fear triggered high levels of dissension especially among right wing political groups. Problems that occurred during integration attempts include erosion of old traditions, new cultural diversity, requisitioning of apartments, different religious mixture, and an increased hostile response to changes. New numbers of migrants created competition between the new arrivals and indigenous Germans. Migrants lived in towns and villages in barrack type camps that had previously been used for a variety of purposes. In the 1930s, barrack camps were used to house the National Labor Service, during the war for the Fremdarbeiter, and after the war displaced persons. As dissension increased, new arrivals withdrew and formed separate cohesion groups. 
Phases of Migration: Post WWII and the State of Official German Migration

Distinct phases are evident when studying German post WWII immigration from 1945 to 1995 (Munz \& Ulrich, 1997) (See Table 7.) The first phase (1945-1949) involves ethnic German (aussiedler) refugees and expellees, re-migration of non-German forced labor, prisoners of war, and survivors of concentration camps. The second phase (1961-1973) portrays the active recruitment of foreign labor by West Germany for guest workers (gastarbeiter) resulting in a large growth of the foreign population. The official end of guest worker (gastarbeiter) recruitment (1973) was unsuccessful in decreasing the numbers of foreigners living in Germany. The most recent phase (1992 to present) introduces new law relating to all foreigners (auslander). Additional changes during this time period focus on restrictions against immigration of ethnic Germans (aussiedler) and asylum seekers. The first official immigration policy was implemented in late 2004.

\section{Ethnic German Law or Aussiedler Law}

The first official German migration law to apply CLEIM to is the ethnic German Law (aussiedler). To understand this law, a basic overview of the policy will be provided followed by the specific application of CLEIM elements. A division will be made between East and West Germany due to the disconnect between these two spheres of Germany during this period of time.

Ethnic Germans (aussiedler) mostly from Eastern Germany, Poland, Czechoslovakia, Hungary, and Yugoslavia migrated to Germany (Munz \& Ulrich, 1997). The logic behind aussiedler policy is "compensation and the equalization of burdens caused by World War II" (Ronge, p.125, 1997). More specifically the following four reasons are noted as rationalization for aussiedler law: a) large numbers of ethnic Germans lived outside of the country's borders in Eastern Europe and Asia due to emigration, country reconfiguration, and ethnic dispersion; b) high levels of abuse during times of war for ethnic Germans; c) a way of compensating ethnic Germans by allowing the jus sanguinis concept of citizenship to immediately apply on arrival to German soil; and d) not seen as immigration policy rather as policy to handle consequences of war (Ronge, 1997). 
Aussiedler's were considered privilege migrants due to the rights of citizenship, job placement, and integration courses upon arrival in Germany (Seifert, 1998). The welcome to this group of migrants was based on the German idea of citizenship and identity based on jus sanguinis traditions (Bade \& Weiner, 1997).

By 1990 , a total of 12 million ethnic Germans had migrated to Germany. Of these numbers, 3.6 million settled in East Germany, comprising $20 \%$ of the total population, while 7.9 million settled in West Germany, making up $16 \%$ of the total population. The peak year of migration was 1990 with 397,000 new arrivals (Munz \& Ulrich, 1997).

Settlement patterns were distinctive for the aussiedler. These ethnic Germans settled mostly in West Germany. The patterns of a North/South divide are less evident. However, some patterns are seen, for example, Romanian's settled mostly in Bavaria, Baden-Württemberg, and North Rhine-Westphalia to a lesser extent (Munz \& Ohlinger, 1998).

Rights for aussiedler are provided by Article 116 of the Federal Republic's post-war Constitution (1949). Areas of this law include: application for regulation, allowances, entry, social services, and integration procedures. This law is not considered immigration policies since aussiedler are actually citizens of Germany (Ronge, 1997). International Situation

The world as a whole was focused on the aftermath of World War II during this time (Daniels, 2004). The countries of open immigration were examining policies to determine if the current policies were going to prove effective in dealing with the suspected rush of displaced persons after the war. In addition, countries were trying to determine the best way to handle the Jewish population left destitute after the atrocities of the Holocaust.

France, Russia, England, and the United States had significant numbers of soldiers continuing to stay in Germany due to the occupation based on the Treaty of Versailles (Turk, 1999). Germany's economy would be dependent on other nations for support in the recent years to come.

National Situation and the Policy Changers: Germany Split into East and West German Federal Republic: West Germany. 
The German Federal Republic, under the direction of Adenauer as chancellor (19491963), had a goal of full sovereignty and ultimately a true world partnership. The offices of chancellor and foreign minister were combined from 1951-1955 in order to more successfully complete this goal. Adenauer's strong belief in Germany helped start the slow rebuilding needed for Western Germany to succeed. Theodor Heuss was the first president and was a compliment to Adenauer's strength and drive (Turk, 1999).

Adenauer and Heuss agreed that Nazi sympathizers should be forgiven and not seen as part of the new post war regime. This was hoped to integrate all people into the new Germany rather than having radical groups split off; thus leading to another German downfall (i.e. neo-Nazi movement). Anti-Semitism laws were passed and reparations were made to Israel starting in September of 1952 (Turk, 1999).

During the leadership of Adenaur, one challenge centered on the number of refugees present in the country. Approximately 10 million, or $16 \%$, of the West German population were refugees. The refugees bonded together and formed a political party called the Association of those Expelled from their Homelands and Deprived of their Rights (BHE) (Turk, 1999).

Ludwig Erhard, the Minister of Economic Affairs (1949-1966) helped Germany to move into the social market economy through economic competition and a secure welfare state system (Turk, 1999)

Through hard work and changes in the system, Germany became a full member of the Council of Europe in 1951 and part of the North Atlantic Treaty Organization (NATO) on April $4^{\text {th }}$ 1949 (Turk, 1999). In December of 1950, the Bonn Treaty repealed the occupation of West Germany and ended all allied control. On May 5, 1955, West Germany claimed complete independence. Soon after, on September 23, 1955, the Hallstein Doctrine ended all relations with any country having diplomatic relations with East Germany. Attempts to join East and West were made by Nikita Khrushchev (Russian leader), but on August 13, 1961 the Berlin wall was erected virtually stopping communication and movement between East and West Germany. Furthermore, this barrier stopped the informal trade and work migration between the east and west (Turk, 1999). 


\section{German Democratic Republic: East Germany.}

The foundations for the social democratic and communist party movements were noted in those that protested Hitler's reign of power (Turk, 1999). During the years of Pieck and Grotewohl (1949-1954), five East Germany states formed the upper house of parliament (Laenderkammer). These five states were later replaced by 15 districts with East Berlin excluded as a militarized zone. Pieck, the first president of East Germany, was in exile during Hitler's reign, and only returned at the end of WWII. Pieck and Grotewohl used the state secret service (Staatssicherheitsdienst) to control the populace (Turk, 1999).

Pieck and Grotewohl devised a five year plan to overcome problems caused by WWII (Turk, 1999). The economic focus was on energy, heavy industry, chemical manufacturing, machine manufacturing, and expensive consumer goods. Unfortunately, the policy resulted in a slower than expected growth of the economy in part due to the trade with mostly Eastern bloc countries. East Germany did succeed in developing and maintaining the highest standard of living in the Eastern block but this was still far behind West Germany. In 1959, the government made agriculture collective in nature following the system already in place for other types of employment (Turk, 1999).

Adenauer did not officially recognize the DDR until the Basic Treaty of 1972 . Some communication for trade in migrant labor started to occur between the East and West during the early to mid-1970s. Workers entering East Germany helped to alleviate some of the pressure on the labor force by providing workers to fill open labor market jobs created by the decrease in fertility rates. From the 1970 s until the 1990 s, East Germany experienced an annual population decrease of $2.47 \%$ (Teitelbaum \& Winter, 1998).

\section{West Germany's aussiedler arrivals.}

Over time the ethnicity of West German aussiedler arrivals changed. In the most recent years, former USSR states (57\%), Poland (32\%), and Romania (11\%) constitute the highest percentage of aussiedler. Due to the high numbers some changes are noted in the laws in the 1990s (Munz \& Ulrich, 1997). Changes in the early 1990s center on the following: reception changes (1990) and war consequences legislation (1993) (Ronge, 1997). These changes set 
limits of 225,000 plus or minus $10 \%$ of the 1991 numbers to enter per year. In addition, applications are required from a current host country. The length and complexity of the form has grown over the years. The applicant must have been born before January 1, 1993.

The goal is to eventually stop migration based on ethnicity due to the amount of aussiedler already residing within Germany (Munz \& Ulrich, 1997). The largest groups currently arriving are from former soviet countries where the applicant can prove discrimination based on ethnicity. To decrease the number of aussiedler entering Germany, the German government is attempting to provide financial support to foreign countries to continue to care for German ethnics living outside of the country whereby supporting ethnic Germans while also reducing the numbers entering Germany (i.e. Russia, Kazakhstan, and Ukraine) (Ronge, 1997).

Status quo attitudes toward aussiedler have historically been more positive than other groups of migrants (Ronge, 1997). Perhaps this is due to the negative treatment of ethnic German inside of the host counties or embrace of aussiedler as full citizens.

\section{Ethnic Germans in Russia.}

Negative treatment for ethnic Germans in Russia included labels as fascists and forcible removal to less desirable parts of Russia (Munz \& Ohlinger, 1998). After removal, other ethnics such as the Chechens, Ingushians, Tatar, and Balts were allowed to move back to pre-1941 areas. Ethnic Germans were not allowed this right. The German language was unable to be spoken in public. The following numbers migrated from Russia to Germany: 12,000 (1958/1959), 62,000 (1972-1980), 753 (1986), 14,000 (1987), and 213,000 (1994).

\section{Ethnic Germans in Romania.}

In Romania, ethnic Germans were allowed to maintain their own distinctive language and culture (Munz \& Ohlinger, 1998). In the mid 1940s, an economic depression created suffering for all people in Romania suffered including the ethnic Germans. Ethnic Germans in the Romanian areas of Bukovina, Dobrudja, and Bessanabial were resettled by the Nazi's at the beginning of WWII. In 1944, 100,000 ethnic Germans left as the German army retreated from Romania. In the late 1950 s and 1960 s, as many as 15,000 ethnic Germans left Romania to reunite with family through a program sponsored by the Red Cross. The 1970s showed a steady migration flow until 
in 1978 an official arrangement between the German and Romanian government allowed only $10,000-15,000$ per year. The one exception to this numbers limit was in 1990 when 111,000 were allowed due to being $1 / 2$ of the remaining ethnic German population. The German Government sends monies to Romania for the Swabians.

\section{Ethnic Germans in Poland.}

The Nazi party forcibly converted Polish people to Ethnic Germans from 1940-1944 (Munz \& Ohlinger, 1998). In the years following, this group was "re-polonized" (p.166).These changes led Poland to deny having a German ethnic minority despite numbers of true ethnic German residing within Polish borders. Despite this denial, Poland did allow migrants to Germany. From 1977 to 1987 , approximately $30,000-50,000$ people migrated from Poland to Germany. The peak year was noted in 1989 with 250,000 migrants. The numbers have decreased from Poland since the changes in the law in the early 1990s.

\section{Portrait of an aussiedler}

The majority of aussiedler work in construction, service, and agricultural jobs due to nonacceptance of training or unneeded work skills (Munz \& Ohlinger, 1998). Problems with employment have led to underemployment and unemployment. Monies were included in the federal budget to assist the aussiedler until the 1990s when reunification took its toll on the national coffers. Overall, an aussiedler's success in the labor market is dependent on the former country of residence, length of time in Germany, and language skills. Ethnic Germans from Romania have higher socio-economic levels than those from Russia and Kazakhstan (Munz \& Ohlinger, 1998).

\section{Influence Groups}

The integration procedures for aussiedler's were so effective that groups of ethnic Germans formed political influence groups called Landsmannschaften. These groups were politically conservative and continue to remain conservative today. In recent years, the Landsmannschaften do not readily accept new groups of foreigners due to a conflict in the way public monies are spent on the new versus old migrants (Munz \& Ohlinger, 1998). Inclusion vs. Exclusion Level 
The Policy Response Continuum labels this policy, albeit not an immigration policy, a positive five. This policy welcomed back ethnic Germans as full citizens; thus aussiedler's received the best possible integration upon arrival in the country (Timmer \& Williamson, 1998) (See Table 1.)

\section{Policy Change}

Just as the majority of policies have unintended consequences so does the aussiedler policy (Ronge, 1997). This policy has forced Germany to accept higher levels of ethical and emotional responsibility for WWII than is necessary. In addition, even though the numbers of migrants is large for Germany, aussiedler migration cannot be stopped completely due to the constitutional revision that made the migration possible in the first place. Payments to host countries to keep ethnic Germans in current entries of residence are resulting in misuse of this policy.

Ronge (1997) suggests that aussiedler policy could be a model for future German immigration policy. The following five components would be applicable: a) the policy is legally spelled out in terms of benefits, applicants, ECT; b) involves reception and integration; c) yearly quotas are set for what the country can fiscally handle; d) applications are completed in the country of origin, and e) sets the naturalization process.

Historical Context between Immigration Policies: German East/West Migration Between the German aussiedler and guest worker programs, east and west migration patterns are important to note. East-west migration patterns were connected to the relationship between East and West Germany (Munz \& Ohlinger, 1998). The governments explained migration from East to West was for political reasons while migration from West to East was for cheap labor. From 1949 to 1961, approximately 393,000 migrants from West to East Germany reported reasons including marriage, family, and ideology as reasons for a move. The numbers virtually disappeared after the building of the wall and the Cold War started.

Guest Worker Law or Gastarbeiter 
The second post- WWII German immigration policy to apply CLEIM is the guest worker (gastarbeiter) law. This section will explore the basics of gastarbeiter policy and then apply CLEIM elements.

From 1946-1973, West Germany's main goal was postwar economic recovery, Wirtschaftswunder (Fetzer, 2000). Due to the war effort, a labor shortage was evident and so the beginnings of the guest worker program, gastarbeiter, began in the 1950 s and lasted until the 1970s.

The transition to gastarbeiter law first focused on the labor market and agreements with specific countries to provide workers (Joppke, 1999). The following are countries Germany had agreements with: Italy (1955), Spain and Greece (1960), Turkey (1961), Portugal (1964), Tunisia and Morocco (1965), and Yugoslavia (1968). Due to low number in the work force, Germany actively recruited workers from these countries in order to fill open job rosters with permits of one to three years in length.

The GDR (East Germany) implemented a similar program in the 1970 s but only recruited workers from other Eastern bloc countries. Later when these numbers were not sufficient, workers were sought from Cuba, Mozambique, and Vietnam. Exit was compulsory at the end of the work permit (Munz \& Ulrich, 1997).

Foreign labor has progressed through various phases from 1959 to present (Herbert, 1990). The first phase of gastarbeiter policy was 1959-1960. Low numbers of migrants were noted during this time period. During 1961-1966, Germany more actively recruited workers by advertising and increasing work agreement with specific countries. Rapid rises in the number of guest workers were noted during this time. From 1967-1973, the numbers of workers practically doubled. The only low year during this time was the recession of 1967/1968. Active recruitment stopped in 1973 due to the large numbers of migrants not returning to his/her homeland and Germany admitted to problems in controlling the number of gastarbeiter's in the country. The numbers of migrants from 1974-1979 were mainly composed of the family members of workers continuing to live and work in Germany. This was an unintended consequence of gastarbeiter policy; permanent settlement of workers and families inside of Germany and the transference 
from a guest worker to an immigrant (Bade \& Weiner, 1997). A slow upward trend of workers has been noted from 1979 to the present (Herbert, 1990).

Due to the large number of family members arriving in Germany, standards were set for family reunification (Motomura, 1997). These standards are part of the Aliens Act (auslandergesetz). People currently living and working in Germany may apply for reunification of foreign spouses and unmarried minor children. To apply for family member admission, the following requirements were needed: a) resident permit (aufenthaltserlaubris) or permanent residence (aufenthaltsberechtigung), b) appropriate housing to include the size and type of housing, and c) appropriate financial means. Children born in Germany to non-German parents under the Citizenship Act are not considered citizens of Germany but could later apply for discretionary naturalization.

As was noted earlier, gastarbeiter law slowly evolved from a individual country work agreement to an official law concerning gastarbeiter's in April of 1965 (Herbert, 1990). Residence and work permits were more readily supplied to nations considered part of the German market with existing trade agreements. Workers could be of five different types: project workers, seasonal workers, border commuters, guest workers, and foreign nurses (Honekapp, 1997). Project workers were contracted for a specific project. Work permits expired at the completion of that specific job and had to be renewed year by year in order to ensure compliance. Regional differences for permits were typically based on the percentage of unemployment in that area. Workers were to receive standard wages and received no social insurance benefits; thus employers had to pay much less to foreign workers than German workers. These types of permits were mostly used for construction work. Seasonal permits lasted from 3 to 9 months depending on the type. The employer had to prove that no German workers were available for that specific type of job. Typically workers were requested by name due to being known by the employer from past work. In 1993, seasonal jobs were restricted to farming, food processing, hotels, restaurants, and carnival work. As of 1995 , approximately $85 \%$ of seasonal workers were from Poland. Border commuters are migrants living within 30 miles of the German border. These workers are expected to return home at night. Restrictions mandate that a commuter may not stay more than 
2 nights per week in Germany. Commuters must sign work contracts and receive standard pay for work. The majority of commuters are from Poland and the former Czechoslovakia region. Guest workers are from the ages of 18 to 40 years. He/she must possess basic language skills and have necessary vocational skills for the specific job. Germany does have some vocational training agreements with certain countries to provide up to 18 months of training for 10,000 migrants. Workers are typically from Poland, former Czechoslovakia, Slovakia, and Hungary. Foreign nurses are recruited for the purpose of: a) providing jobs and helping the market economy of other countries, b) providing a situation to increase the westernization of skills to other countries, c) filling the gaps in German nurses rosters, d) transferring illegal workers to legal workers, and e) decreasing permanent immigration with limited permits (Honekapp, 1997). National and International Situation

The official end to guest worker recruitment was directly after the OPEC oil crisis (Munz \& Ulricht, 1997). The 1973 oil crisis changed labor from highly industrialized cities to less developed areas. This changed the demographics of the working class by gender, ethnicity, and age. Technological advances led to the increased need for skilled labor with flexible work availability (Seifert, 1998). In addition, this crisis triggered a depression in the economies of the Western world (Munz \& Ulricht, 1997). Germany experienced the most severe recession during 19741975. By the early 1980 s slow economic growth regained momentum and the labor market numbers increased with the large number of baby boomers in the work force. Influence Groups

On November 10, 1954 a headline in the Hamburger Echo claimed "Foreign Workers to Replace Army Recruits" (Herbert, 1990). This headline started a debate over the need for workers. On one side the need for workers and on the other side an unemployment rate between 2 and $11 \%$ (depending on the region of Germany). Many German citizens wanted full German employment before seeking workers from other countries. An alternate solution was proposed in October 1955 that included: a) increasing the mobility of workers from one area of the country to more needed areas for work, b) increasing the technical skills of the current labor force, c) increasing the number of German female workers, and d) increasing the number of work hours 
for current German workers. Policy changers and influence groups alike thought of problems with all four suggestions and so the decision was made to recruit foreign workers (Herbert, 1990).

Influence groups, of the 1960 s, pushed for the use of foreign labor for three main reasons: a) the Berlin Wall virtually stopped workers from the East and so an increase in the use of workers from pro west-German countries was accepted, b) high levels of foreign workers due to low numbers in the labor market post WWII, early retirement, and educational time lengthened, and c) labor law changes leading to ease of getting foreign labor market supply (Herbert, 1990).

In the 1970 s, the Green party movement, mostly composed of the post war, generation and students, moved the focus of Germany to the environment and thus decreased the use of nuclear power (Turk, 1999). This influence group officially reached the level of a political party in 1979.

The negative attitudes toward gastarbeiter continued to gain momentum as the number of workers increased. By 1972, over two million guest workers were living and working within Germany. The pressure on the schools and social service systems led many citizens to have misplaced hostility toward workers rather than changes in policy (Turk, 1999).

\section{Policy Changers}

West German Chancellor: Ludwig Erhard.

Chancellor Ludwig Erhard (1963-1966) was previously the Minister of Economic Affairs since the time of the Adenauer cabinet. Unfortunately, Erhard experienced a depression during his time as chancellor. Unemployment was $0.4 \%$ in 1965 and $3.5 \%$ in 1967 . Erhard did work on the relationship between East and West Germany by allowing a visit West Berliners to visit family members in the East. This allowed some 1.2 million people to travel across this border from December 19, 1963-January 5, 1964. The world did not support this work though as the West wanted total isolation of the Communist countries. Under pressure from the radical right, Erhard resigned on November 30, 1966.

West German Chancellor: Kurt Geort Kiesinger.

Kurt Georg Kiesinger assumed the position of Chancellor from 1966-1969 (Turk, 1999). Kiesinger was a former Nazi in Hitler's foreign office. Due to further economic problems, a new 
Minister of Economy, Karl Schiller, was brought in to make change. The Stability Law (June 8, 1967) emphasized policies for full employment at national and state levels, stability of currency, increases in trade, economic growth, and a decrease in inflation. As a result, the gross domestic product did grow from 1960-1968. Kiesinger did have to make decisions concerning right wing party extremists sparked by the Auschwitz Trails of 1963-1968 in which former SS guards were placed on trial. Some Germans denied the Holocaust as allied propaganda and the result was "mixed nationalism, racism, and expansionism with aggressive campaigning in the state elections" (p.156). In 1968, student revolts on the left protested the growing radical right as well as the Vietnam War. An Emergency Law was put into place in June 1968 for troops to enforce order at all demonstrations. In the 1970s, unrest continued with groups such as the Red Army faction led by Baader and Meinhof.

West German Chancellor: Willi Brandt.

Chancellor Willi Brandt (1969-1974) was the first chancellor from the social democratic party (Turk, 1999). He nominated Walter Scheel as the foreign minister. Together Brandt and Scheel were nominated for the Noble Peace Prize in 1971 for a policy known as the East Policy (Ostpolitik). The East Policy involved talks with Moscow and Warsaw in January 1970. The result of these talks was that on August 12,1970, the Moscow Treaty was signed as a "no force" agreement between Brandt and the Premier of the USSR, Alexei Kosygin. The Warsaw Treaty (December 7, 1970) was signed between Brandt and the Minister of Poland, Josef Cyrankiewica for territorial integrity between Germany and Poland, the exchange of ambassadors. While in Poland, Brand commemorated the Jews of the Warsaw ghettos. The Basic Treaty of December 1972 ended the Hallstein Doctrine and allowed friendly relations between East and West Germany, as well as Bulgaria, Czechoslovakia, Finland, Hungary, and Bulgaria. Domestic reform in the early 1970 s improved education, increased retirement benefits, and increased the rights of workers through the Factory Constitution Act of 1971.

Brandt's positive changes slowly eroded in the early to mid 1970s (Turk, 1999). In 1972, the Bundestag began disagreements on the best course of action for the economy. The Olympics in Munich, Germany ended in disaster due to the attacks on Israeli athletes by Palestinians. 
Brandt's personal assistant, Guenther Guillaume, was found to be an East German spy and was forced to resign on May 6, 1974.

Inclusion vs. Exclusion Level

The Policy Response Continuum labels the German gastarbeiter policy as a positive four due to the active recruitment of workers, available housing, and ability to receive a moderate amount of social services (Timmer \& Williamson, 1998) (See Table 1.)

Policy Change

The original intent of the guest worker policy was for individuals to work and then return to his/her homeland. It was found, after the fact, that the likelihood of returning to the homeland decreased as the number of years living and working in Germany increased. The establishment of large numbers of migrants through this policy further encouraged large numbers of later migrants through family reunification. In addition, large numbers of asylum seekers, particularly from Turkey and Eastern Europe, are attributed to the accepting nature of Germany to house large numbers of migrants. The gastarbeiter policy also contributed to significant numbers of children born in Germany to non-German parents (Green, 2005).

\section{Foreigner Law (Auslanderpolitik)}

This section will address the third post WWII immigration law, Foreigner Policy (auslanderpolitik) by providing the basic details of the policy followed by CLEIM analysis. Through the previous experiences of aussiedlers and gastarbeiters, Germany officially devised a Foreigner Policy in 1977 with the following aims: a) to end the future labor migration, b) to devise specific policy for foreigners staying in Germany, and c) to encourage return migration to homelands. The aims of this policy were reconfirmed in October of 1982 by Chancellor Kohl (Green, 2005). The law was revised in January of 1991 and called the Law on the Entry and Sojourn of Aliens in the Territory of the FRG. This center for aliens (auslander) was designed for people not considered German according to the Basic Law, Article 116 (i.e. non-nationals, stateless persons) (Cremer, 1998). This law is usurped by the Law on the Entry and Sojourn of Nationals of the Member States of the European Economic Community and the Law on the Procedure of Asylum Cases. 
Resident permits are required except on rare exceptions by the Bundesrat (Federal Council) (Cremer, 1998). The permit is a visa required before entry to Germany as authorized by the Federal Foreign Office. The Treaty of Maastricht establishes cooperation of home affairs (asylum, border control, immigration control). This treaty is equal to Article 100c of the Treaty of the European Community with the consult of the European parliament set by the nation states that a valid visa before entry. Illegal entry will result in border rejection or non-admission. At entrance to the country, a migrant must have the appropriate paperwork and must consent to fingerprints, photos, and a physical exam. The Federal Bureau of Criminal Investigations (Bundeskriminalamt) evaluates the information on each alien (Cremer, 1998).

Some states, within Germany, require further registration for auslander (Cremer, 1998). The Alien's Office tracks all visas and individual migrants must carry a valid visa that can be produced if asked by authorities. Different states have enacted meldegesetze laws that specifically concern the registration of auslander. These laws are more specific than the generic Auslandergesetz law. Resident information includes: names, date and place of birth, gender, family status, nationality, second residence information, dates of residence, pseudonyms, advanced degrees, and moving information. Hotels and lodging establishments must verify this information for guests. The Central Aliens Register keeps an information system ran by the Federal Office of Administration (budnesverwaltungsamt). This office keeps two separate files: a visa operation file and a general file.

Article 43 of the Auslanderpolitik addresses the topic of deportation (Crember, 1998). An alien is expected to leave Germany if he/she no longer holds a current visa. Deportation, called expulsion (Ausweisung), is defined as the "administrative act that individually orders a single alien to leave the territory" (p.60). Compulsory deportation is only used if the German authorities have a reason to believe that an individual will not leave or will enter another European Union state. The three steps to the deportation process include: a) a warning that fixes a deadline for deportation and provides consequences of non-action, b) an order of deportation, and c) the actual removal of the alien where he/she is taken to the border or placed on a plane. If an 
individual disappears during any part of this process, officials enter a search notice into the General File of Central Aliens Registry.

National and International Situation

The two Treaties of Schengen (June 19, 1990 \& March 26, 1995) defined the common borders of Belgium, Germany, France, Luxembourg, Netherlands, Spain, and Portugal (Cremer, 1998). Both internal and external border controls are explored and based on the "automated international network of Information" known as the Schengen Information System or SIS (p.50). This system contains information on suspicious persons, missing persons, etcetera. The use of SIS is also embedded with the EU Article 175 of the Treaty of the European Community.

In 1989, Mikhail Gorbachev called for an open discussion with the Western world for changes to stop the Cold War. This period would become known as Perestroika (Turk, 1999).

In 1989, Erich Honecher's East German government started to crumble as evidenced by protests, non-Communist participation of Polish and Hungarian Governments, and migration to the West (Turk, 1999). As difficulties continued to rise, Kohl and Gorbachev continued in communication and it was decided to unify Germany. On November 9, 1989, the Berlin wall was dismantled and on May 18, 1990 East and West Germany were officially united economically. The official date of total unification was August 31, 1990 in which the eleven states of West Germany and five states of East Germany were one again.

\section{Interest Groups}

In November 1993, German scholars published the document entitled "Germany and Immigration" (Das Manifest der 60). This work blames integration problems and xenophobic responses to immigration on the lack of true immigration policy. Since Germany continues to piece together law to look at different aspects of foreign migration without devising all encompassing immigration policy, difficulties will continue to occur. These scholars suggest policy focus comprehensively on asylum, labor migration, and immigration (Bade \& Weiner, 1997).

During the 1980s, a lobby was formed, called the Auslanderlobby, to support the rights of foreigners (Joppke, 1999). This lobby was not composed of foreigners but instead of charity organizations and trade unions. An ethnic self organization, "German Helfer", also formed, but 
due to lack of political power it was marginalized by the more powerful Auslanderlobby. The involvement of charity organizations started with the work of these organizations in providing services to foreigners in the 1960s. Charity organizations divided services to foreigners according to language and religion. Examples of charity organizations divisions include: Catholic Church services through Caritas to the Italian, Spanish, and Portugal migrants and Protestant services to the Greeks and non-Christian Turks, Moroccan, and Tunisian.

\section{Policy Changers}

\section{East Germany: Erich Honecker.}

Erich Honecker (1971-1989), the Chairman of the Council of the State in East Germany, was a lifelong Communist. Honecker was imprisoned by Hitler for 10 years due to his Marxist and Leninist views. One of his main areas of interest is on housing, maternity leave, day care, and pensions. In 1974, Honecker supported a Constitutional revision to connect Germany closer to the USSR through the authority of the Council of Ministers over the Council of the State. Honecker helped to spread communism to $3^{\text {rd }}$ world counties due to a belief that this form of government could help lift poverty stricken countries out of this status. Honecker supported Abgrenzung which was a policy to separation between East and West Germany. In the 1980s, East Germany suffered from a downward spiral in the economy due to trade mostly with the other Eastern bloc countries. Before leaving office, Honecker supported increases in technology as a way to revive the ailing economy of Eastern Germany (Turk, 1999).

West Germany: Chancellor Helmut Schmidt.

Chancellor Helmut Schmidt (1974-1982) was previously a Defense Minister (1969-1972) and a Minister of the Economy (1972-1974). Schmidt placed Hans Dietrich Genscher as the Minister of Foreign Affairs. Schmidt and Genscher had to make decisions during the time of the world oil crisis, high inflation, and increased use of nuclear power all of which attributed to social unrest. Germany survived the recessions triggered by the oil crisis better than some countries due to the social welfare system of pensions and programs. Focus on the economy led to less work with the East and instead movement toward stronger policies toward rejection of the East. In 
1975, the Helsinki Accord were signed and a movement toward human rights and a European consensus was started (Turk, 1999).

West Germany: Chancellor Helmut Kohl.

Helmut Kohl was Chancellor from 1982-1988 (Turk, 1999). During the beginning of his time as Chancellor, Kohl had to face disagreement centering on the use of nuclear weapons. President Carstens (1979-1984) was replaced with Richard Von Weizsaeker (1984-1994) during Kohl's tenure. Germany faced her $40^{\text {th }}$ anniversary of the surrender of WWII. President Reagan, of the United States, visited Germany under the invite of Chancellor Kohl and attended a commemoration of remembrance at a concentration camp.

Inclusion vs. Exclusion Level

The Policy Response Continuum labels the auslander policy as a zero. This policy does allow for entrance that is helpful to Germany. Since at the time of this policy, Germany does not report to be a country of immigration, migrants must meet a specific need of the country in order to be considered for entrance. If the need is met, then entrance might be granted as long as the individual fits the restrictions based on entrance by this policy. The combination of entrance accessibility and restriction evens out for the score of zero (Timmer \& Williamson, 1998) (See Table 1.)

\section{Historical Context between Immigration Policies}

Many historical events occurred between the auslander policy (1977) and Germany's first official immigration policy in 2004. Changes included: German reunification, European Union agreements, and new labor migration agreements.

Reunification of East and West: Implications

Unification required merging two separate infrastructures (Turk, 1999). Germany had to write a democratic constitution, which was entirely different than the previous policy, to ensure social rights rather than assume just guaranteed. The disagreement, by the east and west, on the capital ended with the Bundestag in Berlin and the Bundesrat staying in Bonn. Placement of the economic condition of the East was difficult to merge with the West. It was planned to sell Eastern companies to investors so as to bring these companies into a market economy. The first director 
of the agency in charge of this change, Detleu Rohwedder, was assassinated. Disagreement broke out on the best way to economically merge the two countries. Infrastructures in the East such as housing, roads, railways, bridges, and waterways needed updating. Large amounts of money were required to improve the environment in the East. Anger was strengthened in the East when people with Communist perspectives were removed from positions and replaced with people from the West. The privatization of non-industrial property, such as houses, required special care. People were allowed to apply to purchase his/her home. The Solidarity Tax, instituted in 1998, was designed to help make more of the changes needed for full re-unification. Some anger was noted due to this difference.

Ways to handle the lack of monies had to be put into the national systems for pensions and welfare by the East. The government had to address ways to allocate current monies to more people after reunification (Teitlebaum \& Winter, 1998).

Negativity started to brew after reunification, both in the east and west and towards foreigners. The terms "ossie" and "wessies" or easterner and westerner portrays the feelings of separateness that continued after reunification between the former countries (Turk, 1999). On September 17-22, 1991 violence broke out in Saxon-Hoyerswerda with the stoning of some asylum seekers. In Rostock-Lichtenhagen (August 23-27, 1992) applause broke out as homes of asylum seekers were set on fire. On October 10, 1991, in Hunxe, two refugee children were injured during a fire. In Molln (November 11, 1992) and Solingen (May 29, 1993) long-term Turkish residence homes were burned. In Lubeck, on March 24, 1994 a Jewish synagogue was burnt. And in 1995, a letter bomb was sent to a synagogue with a neo-Nazi letter attached. As a result, Kurdish people have attempted to organize though the start of the Kurdistan Labor Party (PKK).

Barbieri (1998) asserts that present day Germany continued to experience three types of immigrant subordination: ethnic discrimination, legal disadvantage, and socioeconomic inequality. Ethnic discrimination is connected to the topic of nation building. As Germany focuses on norms and solidarity of the country, the differentness of migrants becomes increasingly evident. $A$ common identity focus excludes those that are different. Discrimination can be noted in individual 
and collective forms, various contexts and to different degrees. The term used for discrimination against foreigners is aulanderfeindlichkeit. Legal disadvantage is noted as state building is on the rise. An increase in state power leads to a decreased interest in relationship to language, education, and public life, lower political involvement, decreased benefit of economic redistribution, higher levels of hazardous work conditions, and inequality in school and housing systems. Socioeconomic inequality is noted through the disadvantage of laws and regulations focued on German citizenship. Foreigners are unable to enter the job market at competitive rates.

Germany has attempted to unofficially incorporate foreign beliefs into political processes by allowing for expression of complaints on policy issues, national and local issues, etcetera (Klopp, 2002).

Inequalities for German migrants are noted mostly within the education and labor markets (Alba, Handl, \& Muller, 1998). The majority of foreign children are placed in a school track that does not allow attendance at the University. Furthermore, the track at this school does not allow for an apprentice type learning experience. Italian and Turkish immigrants seem to suffer the most with levels of education. Success can be calculated by the size of the city, the socioeconomic levels, and the concentration of foreigners. Success is further compounded by: cultural immersion level of parents (German language ability), nature of migration (sojourner versus settler), and level of discrimination.

Levels of Turkish discrimination are attributed to the distinctiveness of this group through language, food, music, physical characteristics (Alba, Handl, \& Muller, 1998). Approximately $75 \%$ of Turkish families have one parent without German language skills. Turkish children have received more years of education in their homeland versus other migrants. Turkish people are least likely to identify as German and more likely to want to return to his/her homeland.

\section{European Union and German Migration}

The European Union (EU) is composed of a set of member states that attempts to balance national states rights while unifying EU rights (Bulmer \& Lequesne, 2005). To obtain this balance, integration of the following is necessary: a) national governments input into a supranational policy level, b) the incorporation of EU business into the national level, c) EU creates 
increased levels of governmental, institutional, political parties, and international groups and also creates constraints, d) creates questions for logical political action, and e) creates an EU court system to balance the individual national court systems. The foundations of the EU are based on the collection of work on International Theory by Hoffman in which the EU cooperation of states, all of which function with a governmental hierarchy, cooperate within an economically interdependent unit and share an idea of pooled sovereignty.

Germany's changing position in Europe, from the Eastern border of Europe to the center of Europe has created complex changes for the country (Anderson, 2005). Germany has pushed for supra-national policies that will support the economy of the country (i.e. monetary cooperation and competition clauses). During the Nice Summitt (December 2000), the world noted the combination of Germany's blend of old and new policies with the increase in votes for larger member entry, eastern enlargement discussion, and the size of the composition of the European commission. Seven days after the summit, Chancellor Schroeder called for a seven year hold on the "free circulation of laborers" from new central and eastern European countries (i.e. Poland \& Czech Republic). Germany pushed for increased supranational policies to establish clear parameters that will secure the place of the nation, region, and local authorities. Germany's role in Europe has increasingly changed since reunification. Due to changes in recent years, Germany is less willing to finance specific EU initiatives, speaks out more often on specific issues, and provides a realistic approach as compared to the past. Germany is more willing to discuss and bargain in order to center on both long term goals and ways to reach these goals.

In reference to immigration, Germany's involvement in the EU allows for a common market in which "trans-border worker mobility" is acceptable (Monar, 1997, p.59). This supposes an even flow of migration rather than large numbers, as well as an agreement on policies for internal and external controls. Germany receives the highest number of migrants among the European nations since WWII (Seifert, 1998). As the numbers have increased in the 1980s and 1990 s, Germany has established more stringent means to stabilize immigration. These attempts have been leveled out by the EU open borders policy between member countries. 
On December 3, 1991, the Maastricht Report examined the immigration and asylum policies within the EU to assure congruence between member nations (Reerman, 1997). This comprehensive report suggested the following: effective border control, internal restriction for illegal immigration (i.e. no social benefits), internal controls for employment, expulsion policies, and bans on amnesty of illegal immigrants. Beyond internal and external controls, this report suggests higher levels of assistance to help developing and underdeveloped nations to improve standards of living. Other conferences that further addressrd these issues include: Vienna (1991), Berlin (1991), and Budapest (1993).

With the financial contribution to the EU by each member country, approximately six billion annually returns to the country of origin (Honekapp, 1997). Of this amount, $30 \%$ pays for goods within Germany, $30 \%$ for home building, $20 \%$ for self-employment investments, and the rest for miscellaneous.

The countries of Germany, Austria, and Sweden have pushed the EU to focus on the idea of sharing the burden of migrants throughout the member states rather than the bulk appearing in these 3 countries (Marshall, 2000). In June 1993, a conference at Copenhagen focused on the large numbers entering Germany from the former Yugoslavia. At the $5^{\text {th }}$ Council of European Conference of Ministers Responsible for Migration Affairs, in Athens, November 1993, a proposal to help ease the number of migrants in Austria, Denmark, Germany, Norway, Switzerland, and Sweden was vetoed. In a meeting of the European Parliament (January 1994) and the European Commission (1994), a continual message was the increased need for burden sharing. This discussion came to a head in March of 1999 after the events of Kosovo. The EU refused to adopt a common plan for action as proposed by Germany, Sweden, and Denmark. The refusal was namely by the United Kingdom, France, Netherlands, Spain, and Finland (all of which are more remote from the Kosovo difficulties). Instead, the EU agreed to provide monies to neighboring countries that harbored Kosovo refugees due to worries that a plan to accept official numbers might lead to higher numbers than wanted. The inability to form a common agreement led to Germany decreasing the number of immigrants to be accepted from 40,000 to 10,000 . The 
reported change in numbers was due to the lack of burden sharing by the EU and the cost of maintaining refugees without assistance (Marshall, 2000).

Recent EU focus on immigration centers on undocumented migration rather than a more comprehensive immigration policy (Marshall, 2000). An attempt to decrease the entry of non-EU country migrants is at work. The attempt to increase use foreign aide to non-EU countries is expected to help in this matter.

Studies of the current picture in open immigration countries have received more focus than those within the EU (Klopp, 2002). Old models from open immigration countries are ineffective when examining the European experience. The lack of theory for EU immigration must be addressed.

\section{Chancellor Gerhard Schroeder}

Chancellor Gerhard Schroeder (1998-2005) grew up in post war Germany as the child of working class parents. He started in politics in 1963 at the age of 19. He attended law school and joined the young socialists to become the president of the organization in 1978 . He was elected to the state legislature in 1980 and served through 1986. His reform oriented ideas led him to losing the position as an economic leader in the state legislation (1995). Schroeder was elected Chancellor in 1998 and was responsible for relocating the capital to Berlin. The change to the Euro was also during his tenure. He was the first Chancellor voted out of office post WWII (Turk, 1999).

\section{New Labor Migration}

A renewed need for labor migration is based on two main factors: a lower child bearing rate (1.3 per female) and the loss of workers in specific skill areas (Green, 2005). The lack of laborers creates a problem for social programming of health care and pensions. Although promises were noted as early as the mid 1980s, concerns did not arise until the UN and German reports in 2000 . These reports found 500,000 new foreign workers were needed per year for constant labor force numbers of both skilled and unskilled workers (Green, 2005). In the early $21^{\text {st }}$ century, temporary permits were supplied to trainees, contract laborers, and seasonal laborers (Oezcan, 2004). As of 2002, 374,000 contract workers, of which $50 \%$ were Polish, 
received permits. Of the 298,000 seasonal permits, $85 \%$ of the workers were Polish. On May 1 , 2004, many of the Eastern European countries attained full member status into the EU. German worries over increasing migrants from Eastern Europe led both Germany and Austria to limit labor market access of new EU member countries until late 2006. Re-analysis of the numbers might mean an extension of limited access of new member countries until 2011. Free movement is guaranteed by EU policy after 2011 and thus both Germany and Austria will have no choice but to allow movement at that time.

Recent concerns of the populace are focused on implications of rising numbers of migrants in specific parts of Germany and the low socioeconomic levels leading to discontent in the future among migrants. In 2003 and $2004,7.3$ million non-nationals or $8.9 \%$ of the population are migrants. Of this 2 million are Turkish; 1 million are from the former Yugoslavia. Approximately $20 \%$ (1.5 million) were actually born in Germany (Green, 2005).

A correlation is noted between belief of immigration threat and hostility toward immigrants (Fetzer, 2000). The religious minority of Catholic shows no higher connection of pro-immigration. Pro-immigration and rights are noted from other non-German ethnic groups toward new arrivals. An economic correlation is noted with shaping political views and support of anti-immigration political movements.

Migrants are segregated in cities within Germany at a lower rate than within other European countries (Klopp, 2002). Some states have set quotas to decrease the likelihood of ethnic enclaves forming. There is some controversy surrounding quotas as possibly discriminatory. Perhaps the perception of locals is that any small grouping of immigrants is the start of an ethnic enclave. Some believe in the allowance of self selection of where to live rather than isolation.

\section{Germany's First Immigration Law: Zuwanderungsgesetz}

For the purposes of applying the Cappiccie Lawson Evolution of Immigration Policy Model there is not enough information available at this time to effectively perform an analysis on German's first official immigration policy, the Zuwanderungsgesetz. Due to the extreme importance of this policy shift, the basics of the policy are covered. 
The first German immigration law was proposed in December of 2001 and was debated from then until 2004 (Green, 2005). The biggest areas of debate were on integration and labor migration, the number of asylum seekers, and internal security. Zuwanderungsgesetz is a shift of auslanderpolitik from the Federal Labor Ministry to the Federal Interior Ministry. The Sussmuth Commission (composed of members of various political groups) recommended the policy. The regulatory office on migration will include integration efforts and coordination of new labor migration. The official office called the Commission for Migration, Refugees, and Immigration (2002) is viewed negatively by many in power. The decreased focus on help from social groups and para-public institutions is an example of this. Deportation is based on evidence of a threat access without conviction of a criminal offense (tatsachengestutzte Gefahrenprognose).

\section{Future German Migration}

If the current numbers of migration into the EU continue along current levels, Germany will be forced to continue to increase policy restriction. EU agreements to burden share could alleviate the strain from rising numbers, but it is difficult to predict what will need to occur for the EU to consider burden sharing type policies. Perhaps the continued pressure from Germany and Austria, combined with France's resent battles with riots started by migrants, will persuade the EU to re-address burden sharing policy.

"We can reason that were the conditions of relative security, prosperity, and liberty equally obtainable in all states throughout the world, the volume of international migration would decline dramatically" (Klopp, p.9, 2002). 


\section{CHAPTER IV}

\section{APPLICATION OF CAPPICCIE LAWSON EVOLUTION IMMIGRATION POLICY MODEL TO RUSSIA}

This chapter will begin with an exploration of the connection between Russian history and the concept of migration. After providing a basis for understanding the unique nature of migration in Russia, this chapter will then provide an analysis of migration policy from the post-Communist period to present by applying the Cappiccie Lawson Evolution Immigration Policy Model (See Figure 1.) to each specific policy. The application of CLEIM to each Russian policy will begin to answer the research question pertaining to the accuracy of the model (\#5), the role of influence groups (\#1), the role of policy changers (\#2), the role of events $(\# 3)$, and the use of applying the

Policy Response Continuum (\#6). If an important historical event occurred between the discussed immigration policies, this information will be provided in sections of the chapter marked as "Historical Context between Immigration Policies".

The Beginnings of Russian Migration History

"No other major industrial state, and certainly no English speaking country, has suffered a chain of comparable calamities over so long a period." (Hingley, 2003, p.9)

In the $9^{\text {th }}$ Century, the land that would later be known as Russia was populated by Eastern Slavic tribes (Hingley, 2003). These tribes were united through common customs and a common language rather than religion as seen in the Western part of Europe. This changed in the $10^{\text {th }}$ century with the conversion to Christianity. The focus on the Russian Orthodox faith would strengthen the Russian populace during difficult times. In addition, this new religious focus would help to determine out-group dynamics. This is most evident as contact with the outside world grew through a lively trade route between Russia and Constantinople. Russia took products derived from the forest such as wax, fur, and honey to Constantinople and in turn, goods such as 
wine, silk, jewelry, and luxury goods were brought back for the Russian people to enjoy. This success in the trade business, combined with the newly formed out-group bias, encouraged the trade of human prisoners of war to Constantinople. This new "commodity" was quite financially fruitful (Hingley, 2003).

\section{A Period of Invasion for Russia}

The prosperous $12^{\text {th }}$ Century abruptly ended when foreign invaders blocked the Russian trade route (Hingley, 2003). Fear and confusion led to disagreement on how to fight the invaders. Without a united front, Russia was defenseless against a of series of invasions culminating in 1237 with the invasion of the Tatar's. The Tatar's would dominate Russia for two centuries in what has been called the Tatar Yoke. The only light during this dark time in Russian history is the continuance of the Russian Orthodox Church. Although the Tatar's had adopted the Muslim faith, they allowed the Russian people to continue to worship their orthodox faith.

The movement of peoples throughout the Russian lands decreased with the Tatar Yoke (Hingley, 2003). The Russian Slavic tribes were forged together through the common dislike of the overbearing Tatar rule. The continued Russian Orthodox faith further established this bond of togetherness to handle the trials and tribulations brought to Russian lands throughout history.

\section{Domineering Rulers for Russia}

The foreign invasion of Russia was followed by the domination of czarist rule (Hingley, 2003). Tsar Boris Godvnov gained power; developing a closer connection to the West and to the Orthodox Church. Although the Russian people encouraged the strengthening of the orthodox faith, fear surrounded the growing connections with those not of Russian ethnicity. Nevertheless, Peter the Great continued to make connections with the West through traveling on an eighteen month tour of Europe in an attempt to modernize old world Russia using the more modern Europe as an example (Hingley, 2003).

Russia, Austria, and Prussia worked together to annex land in 1771, 1793, and 1795 (Hingley, 2003). Parts of Poland, Belorussia, and Lithuania were incorporated into Russia. These lands were inhabited mostly by non-Slavic people of Jewish ancestry. Numbers suggest as many as 1 million Jews became part of Russia with the acquisition of this new land mass. The 
differences in Jewish customs and speech (Yiddish) combined with the large numbers of this new ethnicity would soon create problems within Russia.

The 1800s: A Period of Change

During the 1800 s, a caste system emerged in which the populace was divided into merchants, clergy, gentry, peasants, and military (Hingley, 2003). As internal division increased, the rulers of Russia wanted more power and control; thus looking outside her borders to conquer the lands of Finland (1809), Bessarabia (1812), and Poland (1815). The increasing size of Russia called for strength in industry and as a result the sectors of forestry, shipping, farming, metal works, and transportation grew. Domination of foreign lands created a power imbalance between Russian citizens and citizens of newly acquired lands. Although movement was allowed between mother Russia and her new borders, this benefited Russian citizens more than the newest inhabitants who were perhaps seen as more second class citizens. Non-Russian farmers were used as Russia demanded, for example to re-settle new sections of land through farming.

Alexander III (1881-1894) inherited this country rife with revolution (Hingley, 2003). Much of his time in power was focused on putting down revolution attempts. A rise in "Russo-centrism" was evidenced through discrimination against ethnic minorities (p.131). This was most obvious in the discriminatory acts perpetrated against individuals with Jewish ancestry. The Jewish faith was quite different from the strong Russian Orthodox religion, and as such, was not easily accepted by the dominate group. Although residence restrictions against Jews had been in place for quite some time, the policies were rarely enforced. In 1891, Moscow residents demanded enforcement of residence restrictions resulting in the forcible removal of Jewish residents from the city of Moscow to ghetto areas outside of the city. "Russo-centrism" resulted in both the ghettoization of Russian Jews and anti-Semitic riots that would continue into the early 1900s (p.131).

Increasing anti-Semitism led to the rise of the General Jewish Labor Union (Wikipedia, 2006). Members were mostly from Lithuania, Poland, and Russia (all of which were part of Russian lands during this time). The political party lasted from the 1890 s until the 1930s. The root of the group was an attempt to unite Jewish workers in the Russian empire under a single communist party to increase recognition as a minority worthy of equal treatment in society. The 
Jewish Labor Union opposed Zionism (the idea of a homeland for the Jewish people) and as such saw migration to Israel as a way to escape current problems. Instead of escape, the party wanted to focus on strengthening their own cultural traditions while gaining power through political activism.

During this time, the Trans-Siberian line was built to increase Russia's ability to transport food and supplies throughout the massive country (Hingley, 2003). Peasant immigrants and convicts were used to build this line. After the completion of this line, many of the workers relocated to Siberia to find work in the mines.

The 1900s: Communism Draws Near

Nicholas // (1894-1917)

Nicholas II attempted to regain control of tumultuous Russia through the strict enforcement of laws (Hingley, 2003). Even with this autocratic form of rule, extremist groups continued to vie for control. In 1898 , the first Marxist party called the Russian Socialist Democratic Labor party formed. In 1903, this party split into two groups: the Mensheviks and the Bolsheviks. The government did not attempt to dissolve the Mensheviks and the Bolsheviks since they were deemed preferable to other extremist groups of the time period.

The early part of the $20^{\text {th }}$ century noted an increase in Pogroms against groups of Russian Jews (Oezcan, 2004). The term pogrom is defined as an attack or massacre against a specific ethnic group. Although pogroms date back to the time of the crusades most historical accounts associate the term with Russian anti-Semitic feelings during the time of czarist Russia. From 1903-1906, over 2000 Jews were killed after a wave of attacks occurred throughout Russian territories. Questions centered on whether this large wave of attacks was spontaneous or started and organized by the Russian secret policy (Okhranka).

In January of 1905 , troops fired on unarmed workers in St. Petersburg square, ignited a revolt and the virtual collapse of the already crumbling Russian government (Hingley, 2003). As a final attempt at power, the government re-instated the Duma (a smaller version of the land assembly). Four separate Dumas were elected from 1907-1912.

World War I (1914-1917) 
World War I was at first supported by the Russian people. As Russian casualties increased, the emperor (Nicholas II) and the populace disagreed on continuing in the war. While Nicholas II was away on the battlefield much of the management of the country fell to the empress Alexandra. The people feared that the Empress, of German heritage, was under the control of Rasputin, a Siberian peasant who was surrounded by much intrigue. A rumor filtered through Russia of a German conspiracy due to Alexandra's heritage and Rasputin's mysterious reputation. Rasputin was assassinated in December of 1916.

Immediately after the completion of WWI, Russia was plunged into a civil war that led to a devastating famine (Hingley, 2003). His power beyond repair, Nicholas II abdicated, with the encouragement of his military commanders on March 2, 1917.

During Russia's civil war, fear and worry continued to rule the country and as a result any person considered different was at risk for acts of hatred (Hingley, 2003). A series of pogroms resulted in which estimates of $70,000-250,000$ Jews were killed. Over 300,000 Jewish children were left orphaned due to the mass killings. Many Jewish people attempted to flee the country, some successfully and some unsuccessfully. Unfortunately, anti-Jewish pogroms spread throughout the world: Poland (various 1918-1930), Argentina (1919), Romania (1927), Iraq (1941), and Libya (1945).

\section{The Beginnings of Communist Control}

"The Party- and in effect a small leading group or individual leader-was deemed the sole possessor of all embracing absolute truth" (Hingley, 2003, p.8)

The Control of Lenin

Lenin was perhaps seen as a voice of sanity in such a chaotic time (Hingley, 2003). The totalitarian Communist regime gained control of Russia in October of 1917 by using Trotsky's previously devised plan for a successful coup (Hingley, 2003). After one week of fighting, Russia was forced under Bolshevik control during a coup known as the Bolshevik Revolution. Lenin was officially Russia's first Communist leader. An estimated 200-300 thousand Russians claimed allegiance to the Bolsheviks. As a result of the overwhelming numbers, the populace supported 
the revolution. As with Nicholas II, the Bolsheviks were seen as a calming force when faced with the other extremist groups pushing for control during this time period.

Lenin dismissed the Constituent Assembly Government on January 6, 1918 and replaced this with the Soviet of People's Commissars (a group of minister's appointed by him and not the people). The first Communist changes included: reforming of the Calendar to the Western style, moving the government back to Moscow (after 206 years), and changing Russia's official name to Russian Soviet Federative Socialist Republic (in 1922 changed to Union of Soviet Socialist Republics or USSR). Trotsky, the People's Commissar of War, built the Red Army during this time (Hingley, 2003).

\section{The First Migration Policy}

The first policy centered on migration was implemented by Trotsky under the approval of Lenin (Felshtinsky, 1982). After the official end of the Bolshevik Revolution, Trotsky ordered all migrants into the Soviet Union to possess a visa and a passport obtained from the certification center in Stockholm, Sweden. An individual's visa and passport had to include photos, visa stamps, and an official authorized signature. Allowing the entrance of immigrants was an attempt to increase the numbers of individuals thought to be easily swayed to the Communist belief system. This thought changed over time and as such immigrant workers were seen in a negative light as possible burdens on the government. Immigration was basically moot from this time until the disintegration of communism (1990).

As of December 5, 1917, the People's Commissar of Internal Affairs (Petrovsky) denied exit of citizens from the Soviet Union (Hingley, 2003). On the rare occasion that a citizen was granted approval to leave the country, officials attempted to ensure that no documents that looked negative on the Soviet Union were taken out of the country. This policy resulted in virtually no literature on post-soviet migration. In addition, this emigration policy would set the precedent of denying exit from Russia until the period of perestoika.

\section{The True Meaning of Totalitarianism}

By this time, the people had come to understand the true meaning of totalitarian control (Hingley, 2003). The Communist regime intended to spread this particular belief system 
throughout the world. In theory, this system was in part ruled by the mandate of the working class. In actuality, Communism and the rulers under this regime dominated all realms of life by demanding strict allegiance enforced by a system of rewards and penalties. Strict control resulted in the populace claiming devoted allegiance outwardly while many followed his/her own private beliefs behind closed doors. This was especially the case with the strong beliefs of the Russian Orthodox Church.

The Terror of Stalin

Stalin became dictator of the Soviet Union in 1928 and quickly moved to establish complete control through the institution of concentration work camps for opponents to his goals (Hingley, 2003). Opponents included individual minority groups (both ethnicity and religious) and anyone deemed a threat to Stalin's increasing power. Under Stalin, policies were regimented in nature and the least resistance was met with forms of torture, murder, and arson.

Stalin was involved in increasing foreign policy in the late 1930s (Hingley, 2003). The Soviet-German pact of August 23, 1939 contained a hidden component for Germany and Russia to gain control of Finland, Estonia, Latvia, Lithuania, Poland, and Romania. This pact was violated when Hitler invaded the Soviet Union on June 22, 1941. In the beginning, Russian peasants welcomed the foreign invader in hopes that foreign control would be less disastrous than Stalin's form of terror. History reports that Hitler made mistakes during this part of his campaign by not focusing on overtaking Moscow, as well as his horrendous treatment of the Russian Slavs and Jews. It was this treatment that made the once encouraging peasants turn against Hitler's invasion.

An example of Hitler's treatment of Russian Jews and Gypsies is noted in a ravine area near Kiev called Babi Yar (Oezcan, 2004). Babi Yar was used as a Nazi massacre site for natives of this Russian province thought to be responsible for a series of bombings against the German troops. Approximately 175,000 of the Kiev Jewish community were forcefully deported, undressed, beaten, and shot. The SS report number 101 reported that only 33,771 Jews were killed on 9-29 and 9-30 of 1941. In addition to the earlier Jewish killings, Oezcan (2004) states that over 60,000 Roma and USSR prisoners of war were shot at a later time. 
In October of 1943, Stalin forcibly deported seven Soviet minorities (Chechens, Ingushes, Karachays, Balkans, Meshketians, Kelmyks, and Crimean Tatars) to the interior of Asiatic Russia. This act was reported to provide protection to these seven groups from a future German invasion. Some historical reports attribute the forced removal as a way to redistribute prime tracts of land rather than protection from outside invasion (Hingley, 2003).

Help from the allied forces of Britain and the United States was received much slower than Stalin anticipated; increasing animosity toward the capitalist west and possibly leading to the beginnings of the Cold War (Hingley, 2003).

Stalin's closest advisor, Zhdanov, died in 1946 (Hingley, 2003). Stalin blamed the death on a team of doctors who were mostly of Jewish ancestry. The increase in anti-Semitic rhetoric is noted during this time by the use of a new term to refer to Jews, "rootless cosmopolitans" (p.194).

After the completion of WWII, the Soviet Union controlled the eastern sector of Germany and seven satellite countries (Albania, Bulgaria, Czechoslovakia, Yugoslavia (until 1948), Hungary, Poland, and Romania (Hingley, 2003). Russia expelled Germans from areas outside the Soviet occupied zone of Germany. Most of the 16.5 million expellees were from Eastern European areas. Others left these areas from fear that the Red Army would be much like previous Nazi control. Some controversy exists on how forcible the expulsion was and who is ultimately responsible for brutal force used during parts of this process.

Small levels of migration continued between the east and west for the purposes of work. The building of the Berlin wall in 1961 ended all migration by virtually isolating the eastern communist countries from the west. To reduce the possibility of resistance from the isolated eastern satellite countries, Stalin imprisoned high leaders and arrested individuals not in complete compliance with the control of the eastern bloc.

Years of Stagnation

From 1964 until 1985, Russia entered a time in history known as the years of stagnation (Hingley, 2003). At the beginning of this time period, Brezhnev was the first secretary and Kosygin the prime minister. The power elite were an aging group of leaders. The focus on the 
"nomenklatura" or a "system of privileged officials" led to high leaders gaining wealth while others suffered during this economic downturn (p.206).

Russia did sign the Helsinki Accords (1975), during the period of stagnation, raising the hopes of western nations that Russia was moving toward more democratic ideas. As such, Western Europe and the United States started to pressure Russia to allow the emigration of Russian Jews (Trier, 1996). The western push for emigration was further strengthened by the United States passage of the Jackson-Vanik Amendment (1974). This amendment denied open trade relations with non-market economy countries that restricted emigration rights.

The combination of this world wide anti-Communism pressure and the Russian economic difficulties of this period led to an unofficial policy allowing the migration of Jews out of Russian territories. Throughout the mid-1970s until the mid-1980s, the majority of Russian Jews relocated to Western Europe, the United States, and Canada. New policy restrictions in the United States and Canada in the mid-1980s redirected Russian Jews to Israel where the jus sanguinis view of citizenship allowed for automatic citizenship. From the mid to late 1980 s, the population of Israel increased by $12 \%$ with approximately 15,000 Russian Jews entering the country. This new form of Diaspora led to a redefinition of Jewish ethnicity and culture identity both for Jews living in the former soviet states and those who migrated to Israel (Trier, 1996).

After Brezhnev's death (1982), Yury Andropov retained power. Although he attempted to solidify economic change, Andropov was unable to implement overarching policy change due to his failing health. After Andropov's death (1984), Konstantin Chernenko retained power. Much like the previous leader's time, Chernenko's health did not leave much time to drastically reform the ailing Russian economy. Overall, through this short run of leaders, no massive changes or growth occurred.

Nikita Khrushchev: A New Type of Communist Ruler

Khrushchev attempted to increase international and domestic policy and as such the tight control of Russia slowly changed (Hingley, 2003). Talks between the east and west occurred more frequently. Khrushchev's policies opened the door for Gorbachev's perestroika period in which migration would drastically change. 
Russian Federation Migration Policy since the End of Communism

The evolution of migration in Russia is distinct from the other countries studied in this analysis. The complex nature of communism has led to numbers of individuals exiting the country (emigration), numbers of internal migrants from former Soviet Union states (FSU) entering the country, and numbers of labor force migrants (immigrants) entering the country (Heleniak, 2002). Part of this confusing mixture is a result of the FSU being composed of over 100 nationalities and 53 distinct ethnic groups.

The following sections of this chapter apply CLEIM to post-Communism Russian migration policy (See Table 9.)

\section{Emigration: The Freedom of Movement Policy (1991)}

"They went from being members of a privileged majority who arguably saw their homeland as the entire Soviet Union to minority members of 14 newly independent nations" (Heleniak, 2004, p.99).

Until 1987, exit from the Soviet Union was restricted and strictly enforced by the Communist Government (Dietz \& Segbers, 1997). During Gorbachev's perestroika period, many policies, including emigration policy, moved into a more liberal phase. In May of 1991, the Freedom of Movement policy was implemented to allow freedom of movement to Russian citizens. This policy included the ability to migrate freely including emigration from Russia to a foreign country with the intent to remain outside of Russia to live and work. International and National Situation

The slow reform of the late 1980s, in Russia, is attributed to the change process connecting economic change with political change (Tikhomirov, 2000). This connection resulted in a chain reaction in which a political crisis triggered economic crisis and vice versa. This constant chain of connection was evidenced by rising crime rates, levels of social inequality, and the existence of extremist groups.

Progress did occur in the infrastructure of new market structures such as the opening of banks, the start of a stock exchange, and the beginnings of import/export companies (Tikhomirov, $2000)$. By the end of the 1990 s, financial stability had been obtained, but this collapsed with the default on state debt repayments on August 17, 1998 (see Table 9). 


\section{Emigration.}

In addition to economic and political worries, Russia started to focus on the number of migrants exiting the country (Shevtsova, 1992). Rather than the expected numbers, emigration from Russia did not reach the high levels expected. Individuals that exited the country were of two types: ethnic minorities returning to ethnic homelands (i.e. German aussiedler) and victims of ethnic discrimination (i.e. Jewish individuals). Emigrants traveled to: Germany (59\%), Israel $(25 \%)$, and the United States (11\%). Characteristics of emigrants by ethnicity were German (43\%), Russian (38\%), and Jewish (10\%).

Internal migration.

Internal migration also increased from the passage of this policy in part due to the push factors of negative treatment and conflicts within the FSU states (Korovkov \& Zaionchkouskaia, 2004). The Chechen conflict, the Ossetian-Ingushian conflict, the Nagorno-Karabakh conflict and civil wars in Afghanistan and Tajikistan have attributed to the migration to Russia from chaotic homelands (Dornis, 1997).

Despite the chaos of some countries, migration from the Former Soviet Union states (FSU) is mostly received from the Ukraine, Kazakhstan, and Uzbekistan (Heleniak, 2004). The numbers of FSU migrants to Russia peaked in 1994 with a total of 612,378 and evened out to approximately 70,000 in the early years of the $21^{\text {st }}$ Century. Population experts suggest that the peak year was mostly due to the return of Soviet troops after the official withdrawal from the eastern satellite regions and the return of union workers that had worked outside the country under soviet contract. This contract work system collapsed after the breakup of the USSR.

An exception.

As noted in the history of Stalin, the Communist government forcibly deported groups into the interior areas of the Soviet Union (Dornis, 1997). Over the years since the removal, many groups had been allowed to return to ethnic homelands. This is not the case for the Crimean Tatars who were specifically moved due to false allegations of a connection with the Germans during World War II. The Crimean Tatars are noted for the closeness to their ethnic homeland and want to return to this "sacred" area. Approximately 300,000 to 500,000 Crimean Tatars 
continue to remain outside of the ethnic homeland in the areas of Siberia and Uzbekistan. Social characteristics of increased unemployment, increased crime, and extremist activity are noted possibly as a result of the disconnect that resulted from the forced removal.

\section{Influence Groups}

The more affluent western European nations have influenced policy in Russia. With the passage of the Russian freedom of movement policy (1991), western European nations attempted to implement policies to stop large numbers of migrants from Russia and the former satellite countries moving into European Union states (Wronski, 2004). In order to make decisions on East-West migration worries, the EU has held the following summits: a) Tampere Summit (October 1999) in which the EU agreed on policies, rights, and management of internal and external controls, b) Seville Summit (June 2002) in which the EU looked at reception totals, further discussed rights of migrants, explored ways to decrease racism, brainstormed ways to prevent abuse of asylees, and improved programs to refugees and c) Thessaloniki summit in which the EU focused exclusively on numbers from the East and ways to restrict and share the burden of the possible numbers. Although no definite decisions were made, Germany and Austria decided to not allow migration from new EU countries for a period of 3 years in order to stop an East-West flow of migrants.

A committee on migration affairs was formed under the Ministry of Labor and Employment to determine the "picture" of 1991 migration (Chudinovskikh, 2005).

Policy Changers

Mikhail Gorbachev attempted to reform the political system of the Soviet Union government by the process of "revolution from above" (Teitelbaum \& Winter, 1998, p.91). Rather than the peasant class attempting change, Gorbachev wanted the government to create beneficial change for the people. This change called for a reconstruction period (perestroika) in which openness (glasnost) would be a guiding factor (Hingley, 2003). Change would occur without the iron control of the past experienced under the totalitarian regimes of Lenin and Stalin. Although many supported this period of change, the old regime (nomenklatuar) was resistant to Gorbachev's plan (Teitelbaum \& Winter, 1998). 
At the root of the change system was a new legislative body, the Congress of the People's Deputies, composed of 2250 elected members and second chamber called the Supreme Soviet of 450 members elected by the People's Deputies (Hingley, 2003). This new form of government was not democratic in nature but allowed for the ability to discuss change without negative ramifications. In addition to government structure reform, change can be identified in the decrease of censorship controls, allowance of a variety of political parties, and an increase in foreign policy.

Over time, the perestroika period resulted in the following: a loss of control over the eastern satellite countries, attempts at power by ethnic minorities, and finally the dissolution of the USSR (Teitelbaum \& Winter, 1998). The changes within the satellite countries, along with the breaks in the Communist control of the past, contributed to the end of the Berlin Wall (1989). The satellite countries would gain independence soon after the symbol of communism was removed. Inclusion/Exclusion Level

The Policy Response Continuum labeis this policy a positive five since the focus is on freedom of movement through the self determination of an individual to choose what is best. Both internal migration and emigration are allowed under this policy (Timmer \& Williamson, 1998) (See Table 1.)

Policy Change

Recent research has noted a correlation between emigration and level of education, occupation, income level, and urban residence (Heleniak, 2004). This correlation expresses itself in two distinctive ways. As education level increases, individuals are more likely to leave FSU states to move to the Russian Federation. The FSU states are experiencing a "brain drain" due to this recent phenomenon. The Russian Federation is receiving those migrants with higher levels of education just as others are leaving the country; thus a "brain drain" did not occur in the early 1990s. It was hypothesized that if emigration levels continued at the current rate the Russian Federation might experience a problem with the level of the populace in relation to education in the future.

Periods of Immigration Policy 
The previous Freedom of Movement policy was the first of many Russian policies attempting to address the concept of migration. From 1992 to the present, Russia has attempted to more comprehensively handle migration (Heleniak, 2004). Through a slow process, stages of policy were formed to deal with the evolving problems associated with massive migration (see Table 9.). The first period, lasting from 1992-2000, focused mostly on the forced migration problem. Key features of this time period include: Russia's first attempt at immigration policy, through law formation and the establishment of a federal migration service attempts were made to match policy to international standards during this time period. The second period of migration policy, lasting from 2002 to the present, focuses mostly on labor migration flows. Key features of this period include: the development of legislation to restrict migration, increased efficiency in managing migration, and more experience in the migration management process (Chudinovskikh, 2005).

\section{Citizenship Law (February 1992)}

The basic history of the Citizenship Law of 1992 will be discussed followed by the application of CLEIM. After the formal breakup of the Soviet Union, Russia wanted to re-define the concept of citizenship and attempted to do this with the Citizenship Law of 1992. The basics of this policy are provided and then the elements of CLEIM are applied. The historical definition of Russian citizenship has been an interesting combination of the jus sanguinis and jus soli type (Chudinovskikh, 2005). In alignment with jus sanguinis, citizenship at birth is derived from having one or more parents of Russian citizenship. In alignment with jus soli, an infant born in Russia that is abandoned will be considered a Russian citizen.

The 1992 Citizenship Law granted Russian citizenship to "all those who resided permanently in Russia, and to all citizens of the former Soviet Union, including non-Russians, residing in the former Soviet Republics who moved to Russia before 2000" (Heleniak, 2004, p.111).

International Situation

The Gulf War continued during this time, led by the United States, to remove Iraqi forces from the country of Kuwait. This war helped to build an affinity between the United States and 
Russia due to Russia's difficulty with terrorist cells in both Chechnya and nearby Afghanistan (Wikipedia, 2006).

The European Union formed (1992) as a group of 25 countries, under the Maastricht Treaty, to have agreement on policy in the following areas: health, economic, foreign affairs, and defense. A single market currency was established between the member nations. A supranational European court superseded national courts of member countries. The slow movement of Eastern European countries into the EU would effect future economic and political decisions of Russia (Shevtsova, 1992).

\section{National Situation}

Individuals in positions of authority (both federal and local) remained split toward feelings of democracy during this time (Colton \& McFaul, 2003). The largest indicator of feelings toward democratic ideas was age. As age increased, the level of comfort with democratic ideas decreased and as age decreased, the level of comfort with democratic ideas increased.

\section{Policy Changers}

Boris Yeltsin was the Russian President from 1991-1999 (Remington, 2003). Yeltsin was a member of the Communist Party from 1961-1990. During this time, he worked his way up through the administration serving in positions within government and eventually the First Secretary of Moscow (i.e. "mayor" of Moscow). In his positions appointed by Gorbachev, Yeltsin was labeled a "reformer". In 1987, he quarreled with a high ranking official and was stripped of much of his power by Gorbachev. Without permission, Yeltsin spoke in front of a governmental planning meeting expressing his frustrations with the slow and ineffective change within the Russian Federation. This show of anger resulted in a demotion to a position within the construction department. It is alleged that Yeltsin was hospitalized after this humiliating experience but later used the incident to launch himself into higher levels of government using his reform campaign. In 1989, Yeltsin was elected to the House of Deputies as the representative from Moscow. From this position, he gained much favor and on June 12,1991 won $57 \%$ of the popular vote as the President of the Russian Federation over Gorbachev's selected candidate, Nikolai Ryzokov. Animosity continued between Gorbachev and Yeltsin and on December 24, 
1991 the Russian Federation officially replaced the USSR seat within the United Nations.

President Gorbachev resigned and this is officially marks at the end of the USSR. During his presidency, Yeltsin experienced a lack of support and as a result forgot many of his own ideas of increased presidential decrees (ukaz). The number of $u k a z$ led to the Duma viewing Yeltsin negatively and attempting to push for impeachment in 1999. An official impeachment attempt did not occur but Yeltsin would leave office soon after and name Putin as his successor.

\section{Influence Groups}

Information from this time period concerning the feelings of the Russian populace toward migrants provides the following attitudes: rigid stereotypes, high negative focus on nonCaucasian migrants, and high levels of "migrantophobia" (Badyshtova, p.45, 2005). An inverse correlation is noted between negative attitudes toward migrants and migrant level of education, place of origin, and occupation. As the level of education and occupation increases, the strength of negative feelings towards migrants decreases. A portion of this research was gathered on college students which noted higher levels of acceptance than the general population, especially for Russian speaking immigrants.

\section{Inclusion/Exclusion Level}

The Policy Response Continuum labels this policy a zero due to the combination of inclusive and exclusive pieces of the legislation. The 1992 Citizenship act is inclusive in that the definition of citizenship was expanded to include minority populations that lived inside FSU states and migrated to the Russian Federation as citizens. It is exclusive, in the inherent nature of any citizenship policy, in that particular individuals may not receive the title of citizen and thus the benefits of citizenship (Timmer \& Williamson, 1998) (See Table 1.)

$$
\text { Immigration Control Act (1993) }
$$

The policy basics of the Immigration Control Act of 1993 will be discussed followed by the application of CLEIM elements. This act established the Federal Migration Service (FMS) as the implementation arm of migration policy (Heleniak, 2004). The FMS was responsible for control and monitoring official services in relation to migration. Tasks included: accepting citizenship applications, migration documents, registration papers; issuing documents; controlling the 
number of foreigners; promoting activities to prevent irregular migration; implementing policies for refugees and asylees; controlling foreign labor; retaining control over the Russian Federation citizens abroad; and coordination of all former Soviet states migration (Chudinovskikh, 2005).

The FMS was operated by the Vice Minister of Home Affairs (Chudinovskikh, 2005). Under the Vice Minster are the following departments: Department of Citizenship, Department of Visa and Registration, Department of Crisis Situations, Department of Foreign Labor Migration, Department of Passport Issue and Population Regulation, Department of Information Resources, Department of International Cooperation and Judicial Supply, Department of Financial and Economic, Department of Managerial and Analysis, and Department of Control and Office Work. Individual organizations are for FMS representatives abroad and FMS centers (i.e. passport and visa information centers, center for citizenship claims, and center for information for visa invitations).

\section{National Situation}

In the early 1990s, the USSR dissolved and divided into independent states; the largest of which is the Russian Federation (Hingley, 2003). The newly formed independent Russian Federation formed a new constitution and governmental system.

\section{Formation of the government.}

The 1993 Russian Federation Constitution has two sections (Remington, 2003). Section I includes nine chapters covering the following: a) basics of the constitutional system, b) rights, c) Russian Federation, d) president, e) Federal Assembly, f) Government of the Russian Federation, g) Judicial Branch, h) local self-governments, and i) constitutional amendments and revisions. Section II includes concluding and transitional provisions.

Under the Russian Federation Constitution, the Federation Council is the upper house while the state Duma is the lower house of government (Remington, 2003). The Federation Council is composed of two representatives from each of Russia's 88 federal subjects which include: 21 republics, 48 provinces, 7 territories, 1 autonomous province, 9 autonomous districts, and 2 federal cities. (See Figure 3.) The state Duma is composed of 450 deputies that are elected for four year terms. The Federation Council is responsible for specific types of legislation but has 
the power to examine any bill passed by the Duma within two weeks of the law's passage to veto the bill. This safe guard is not full proof since the passage of any law or the veto can be overridden by the Duma. The Duma and the Federation Council can override the president's veto with $2 / 3$ a vote of both houses. If the president has specific policy he/she is interested in getting passed, it is in the benefit of the president to have majority support within the Duma. Specific measures may be addressed by presidential decree (ukazy) but this has been rare with the most recent president of the Russian Federation due to the ability of angering the houses of Government.

International Situation

The world was continuing to adjust to the inclusion of Eastern Europe into the world market. New developing countries, especially those under the former control of the USSR, were slowly making connections through work and trade agreements to rebuild the economies of the new governments. These developing countries were attempting to form connections that would mean total inclusion in the European Union in the future.

Influence Groups

In 1993, the top ten influence groups were the following: the President, the gazprom, the electric companies, the oil companies, the central bank, the federation council, the mass media, the criminal groups, and the oligarchs (Segbers, 2004). (See Table 8.)

\section{Policy Changers}

Yeltsin continued to remain in power at this time (Hingley, 2003). The disconnect between his ideas and the ideas of the government continued to increase. As Yeltsin demanded more decrees, the government continued to more vehemently resist his ideas. A lack of unity among the policy changes was not helpful for a new growing country post-Communist control. Inclusion/Exclusion Level

The Policy Response Continuum labels this policy a negative three. This policy instituted a new level of immigration control through the development of a division of the government to specifically focus on migration. This branch of the government implemented restrictive policies such as migration laws, registration laws, and deportation provisions. Restrictive measures were 
used to grant entry to chosen migrants while excluding many other types of migrants (Timmer \& Williamson, 1998) (See Table 1.)

Law on Entry and Exit from Russia (1996)

The basics of the Law on Entry and Exit from Russia of 1996 will be explored followed by the application of CLEIM. Russia realized the unique nature of its use as a land bridge from the fourteen surrounding countries: China, Japan, Finland, Norway, Georgia, Poland, United States, Ukraine, Latvia, Mongolia, Kazakhstan, Belarus, Estonia, Azerbaijan, and North Korea (Heleniak, 2002). (See Figure 4.) As a result of this realization, the Russian Federation tightened external controls to enter and exit the country resulting in mandatory visas (except most FSU regions), resident permits, and more documentation for specific categories of foreigners through the implementation of the Law on Entry and Exit from Russia (Chudinovskikh, 2005). (See Table 9).

Penalties are spelled out by this law both for individual undocumented migrants and employers of undocumented migrants (Chudinovskikh, 2005). Punishments for migrants include deportation and fines where punishments for employers are mainly monetary.

National Situation

At the end of the $20^{\text {th }}$ Century, Russia started to focus more heavily on the negative population growth (Rybakovsky, 2005). During the early 1990s, it was evident that the population was decreasing, but the numbers of migrants from the FSU states were expected to help balance out this decrease. By the year 2000 , the migration of the Russian ethnic minorities was not as helpful in dealing with the problem. This is partially due to post war changes in age, sex, reproductive behavior, socioeconomic changes, and media influences on sexual practices. The mortality rate is increasing as the population ages and the fertility rates continue to decrease. The higher focus on this population crunch has caused some policy changers to look more heavily to ways to pull former FSU migrants and to decrease foreigners from other places.

In May 2000, the Russian Government officially dissolved the Federal Migration Service and placed duties concerning migration and naturalization within the new department named the Federal Affairs, Nationalities, and Migration Policy (Heleniak, 2002).

International Situation 
As discussed in the United States chapter, the international focus of 1996 is on the struggle for power. Iraq refused to allow the UN investigation team to inspect for weapons of mass destruction as was allowed by the agreement post Dessert Storm. In Afghanistan, the Taliban control of the government and in Zaire tribal warfare between the Tutsi and the Hutu began (Wikipedia, 2006).

Influence Groups

Russian citizens were asked the question in the late 1990s "What is your attitude toward migrants?" and asked to reply with positive, indifferent, negative, or no opinion responses. Of those surveyed, $34 \%$ replied positive, $24 \%$ indifferent, $20 \%$ negative, and $22 \%$ no opinion (Chudinovskikh, 2005). This research suggests the majority of status quo members have opinions other than favorable concerning attitudes toward migration.

\section{Policy Changers}

Yeltsin was re-elected president in 1996 with winning a small amount of the popular vote over Gennady Zyuganov (Wikipedia, 2006). It is reported that Yeltsin's run for the presidency was financed by highly influential businessmen (oligarchs) who gained wealth due to connections with Yeltsin during the beginning of his first term as president. One of the key backers, Roman Abramovich, was allegedly protected from prosecution of criminal charges due to his connection with Yeltsin.

In August of 1999, Yeltsin fired his cabinet (Wikipedia, 2006). This was the fourth massive change of the cabinet and as such Yeltsin was known for "impulsive firing and reshuffling staff" through the history of his presidency.

Inclusion/Exclusion Level

The Policy Response Continuum labels this policy a negative two due to the selective sources of entry through the use of more restrictive entry and exit control (Timmer \& Williamson, 1998) (See Table 1.)

Law on Judicial Status of Foreigners (November 2002)

The basics of the Law on Judicial Status of Foreigners of 2002 will be addressed followed by the application of CLEIM elements. November 1, 2002 the Russian Federation instituted two 
part foreigner registration cards for entry into the country (Heleniak, 2002). These cards were placed inside an individual's passport when registering for a visa to travel to the Russia. Upon entry to the country, the immigration official takes one part of the registration card which is then registered with the Ministry of the Interior. The second part of the registration card remains with the foreigner to confirm identity and legal status to be in the country. Upon leaving the country, the immigration official removes the second part of the registration card as proof of exit from Russia.

\section{National Situation}

In 2002 , the government moved the department handling migration and naturalization to the Ministry of the Interior (Heleniak, 2002). This is the same department that is responsible for the administration of Russia's police department. The government reports that the move to this department is due to lack of funding to the previous department as well as the need to increase the restrictive nature of policy implementation toward undocumented migrants.

Russia conducted the first official large scale census (Heleniak, 2002). In addition to gathering basis demographic data, specific questions were included to target information on migrants (both legal and undocumented).

\section{International Situation}

The international situation in 2002 is highly focused on the idea of security due to the world wide reaction to events in the United States on September $11^{\text {th }}$. This security focus is evidenced by tighter airport controls and surveillance systems to watch suspected terrorists. Although some disagreement ensued due to the United States decision to enter Iraq, the international community is in agreement about wanting to secure their homelands and insure safety for all during international travel.

Policy Changers

President Putin took office in 2000 after past positions as an intelligence officer, Kremlin staffer at the national level, director of the Federal Security Service, a National Security advisor, and Prime Minister (Herspring, 2003). Perhaps the role that brought Putin into the eye of the 
public was his decisions as Prime Minister to use force during a Chechen uprising. This strength was viewed as what Russia needed to ensure order and stability in the $21^{\text {st }}$ Century.

Petrov and Slider (2003) suggest that Putin has portrayed a difference between his stated goals of change and actual implementation after entering office. A shift to a centralized government has changed the system to one based on vertical power that over time might contribute to less checks and balances between the branches of government. "If implemented fully, the result will be a vertically integrated and horizontally fractured state "(Petrov \& Slider, p.222, 2003). This quotation is based on the idea that separate regions of Russia will require higher levels of power than provided by a vertical system to develop politically and economically.

Putin and reform.

From 2000-2001, Putin started to implement change in the following areas: new land code (i.e. ownership, purchase, and sale of land), new labor code (i.e. union agreements, employer and employee rights), taxation changes (i.e. flat income tax rate, unified social assistance funds, new sales tax), judicial changes (i.e. expansion of jury trial system), civil code reform (i.e. banking changes, increasing inheritance rights), and political reform (i.e. stopped party regulation and increased membership requirements). Many of these changes were allowed to occur due to improvement in the policy making process through more efficient coordination between the presidential office and the houses of government. In addition, Putin started a strategic planning committee (tsentr strategicheskikh razrabotok) as a way to plan and submit policy drafts to the Duma (Remington, 2003).

Putin and foreign policy.

Putin is perceived as increasing international foreign policy during his tenure (Herspring \& Rutland, 2003). As is typical, focus on international policy can lead to less work on the domestic front. An example of strong foreign relations is Russia's relationship with the United States after the September $11^{\text {th }}$ incident. Russia provided intelligence and search/rescue assistance. In addition, Russia supported the United State's anti-terror campaign against Afghanistan (Kipp, 2003). The anti-terror support continued in discussions at the Asia-Pacific Economic Cooperation Forum. As a result of these connections, the United States reversed previous focus on the 
Chechnya situation to fit Russian policy on this situation (Herspring \& Rutland, 2003). Public opinion polls show continued Russian support for foreign policy, in large part due to positive domestic indicators.

\section{Putin and anti-corruption}

From 2000-2002, Putin focused an anti-corruption campaign targeted at power struggles and problems with legitimacy throughout the country (Coulloudon, 2003). During communist regimes, anti-corruption campaigns were associated with discrediting your enemies rather than truly ferreting out cells of corrupt officials. The literature suggests it is truly to early to note if Putin's anti-corruption forum will make positive changes or rather it will only increase the vertical executive power base.

Putin and the media.

Since 2000 , the growth of non-state controlied television, newspaper, and radio has grown exponentially (Lipman \& McFaul, 2003). On the surface, Putin supports free press but there is some controversial information on whether this support is a sincere attitude or more for acceptance from the western nations. It is hypothesized that as the Russian middleclass grows a push for continued and increased free press will occur.

Influence Groups

In 2002, Putin appointed police general, Andrei Chernenko, as the Deputy Minister of the International Migration Service in order to improve the process of immigration and naturalization (Blagov, 2002). Regional resettlement programs were re-formulated to move migrants to areas of the country in the North and East that needed workers. Chernenko established a registration policy for Moscow in which identity checks occurred both in public and private. Reports of corrupt officials requiring payment from undocumented migrations for "looking the other way" or providing fake documentation are rampant.

In opposition of the status quo, a non-governmental organization formed in 2002 called the Human Rights Defense Assembly advocates for amnesty on behalf of the current undocumented within Russia (Blagov, 2002). Inclusion/Exclusion Level 
The Policy Response Continuum labels this policy a negative one due to the increased level of restriction of entry cards. Due to not labeling a specific group of people to restrict, the policy remains at a lower negative level than if the entry cards were only for one specific group rather than all entrants into the Russian territory. It is important to note that the majority of FSU states doe not have to use entry cards so there is some level of preference taking place (Timmer \& Williamson, 1998) (See Table 1.)

Migration Regulations (2003)

The basics of the Migration Regulations of 2003 will be explored followed by the application of CLEIM elements. The passage of the Migration Regulations (2003) moved migration into two new spheres: internal and foreign migration (Chudinovskikh, 2005). Internal migration regulations will focus on not allowing further depopulation of the North and East of Russia. Foreign migration regulations attempted to draw individual migrants, to Russia, with higher levels of human capital.

International Situation

At the international level, in the early $21^{\text {st }}$ century, increasing numbers of countries are focused on migration due to the world wide number of migrants. Compounding this issue is the global response to terrorism in ways to increase national security. As a result of the numbers and national security, a dilemma on how best to change policy has led to policy views of two types: conservative and liberal (Rybakovsky \& Ryazantsev, 2005). Conservative policy views focus on the negative consequences of labor migration and support policies to regulate the flow of labor migrants through strict enforcement of internal and external controls. Liberal policy views focus on the use of labor migration to fit Russian employment needs and as such to base the numbers and types of migrants allowed to enter the country on the current labor market economy. Rybakovsky and Ryazantsev (2005) encourage Russia to consider a third type, reserved, that combines the need for workers with the experience of other long term migration countries in best practice procedures to implement the most effective policies.

National Situation 
In 2003, Moscow planned and started a database to track migration trends in hopes of gathering exploratory data to use to determine ways to deter undocumented migration (Heleniak, 2002). Estimates of undocumented migrants, in Moscow, range from 250,000 to $7,000,000$ (Yudina, 2005). The increasing numbers are suspected to be based on: a) lack of past experience with large numbers of undocumented migrants, b) lack of a legislative base, c) ineffective internal and external controls, and d) employment problems. With $50 \%$ of all migrants to Russia living in Moscow, the resulting problems are noted in higher crime rates and increasing levels of tension among the locals toward migrants. Ethnic enclaves are forming in the following areas of Moscow: Chinese (Northwest), Georgians (Northeast), Azerbaijani (east), Southeast Asians (West), and Armenian (Southwest). Increasing numbers of migrants are noted from Vietnam, Afghanistan, North Korea, Somalia, Sudan, Ethiopia, Iran, Iraq, and Turkey. The high numbers of undocumented are entering as non-visa individuals from FSU states, expired tourist or guest visas, and false documents presented at border (Yudina, 2005). Influence Groups

In 2003-2004, the top ten influence groups in Russia consist of the following: the President, financial actors, central bank, electric company, power ministries, gazprom, armament exports, oil companies, Federation counsel, and mass media (Segbers, 2004). (See table 8.)

In Moscow, the status quo Muscovites supports the following policy models: total exclusion (24\%), segregation (43.9\%), full acceptance (5.4\%), and assimilation/integration (23\%). When asked how migration changes Moscow, $50 \%$ report an increase in crime, $37.4 \%$ report an increase in unemployment for Russians, and 36.5\% report an increase in illegal activities (Yudina, 2005).

\section{Policy Changers}

Russia is still mostly influenced by President Putin as reported by Segbers (2001). The presidency is attempting to explore ways to deal with the following policy problems: a) policy decisions based on a combination of need and fear rather than data, b) the permit process it so difficult and takes a long time to obtain, c) police registration is complicated, and d) deportation and monetary sanctions are the only ways to battle illegal migration. These problems are 
compounded by the corruption of officials, inefficiency of border patrol, resource limitations, and no civil control over migration control agencies (Chudinovskikh, 2005). Inclusion/Exclusion Level

The Policy Respone Continuum labels this policy a zero due to the balanced nature of inclusion of specific migrants while maintaining the exclusionary nature to other migrants. Inclusion is offered to those migrants from FSU states and migrants with higher human capital while excluding migrants from other countries with lower levels of human capital (Timmer \& Williamson, 1998) (See Table 1.)

Future Policy Ideas for Russia

Change for Russian immigration decisions must occur at the macro (state) and mezzo (regional) and micro level to be most effective (Rybakovsky \& Ryazantsev, 2005). Macro level change of policy will reduce the control of the Ministry of Interior Affairs and encourage a global migration focus. Mezzo level policy change will dissolve the disconnect between the regional and federal government. Micro level change will focus on the bribery and corruption of migration officials and the obstacles of individual migrants in obtaining citizenship, work, and access to social services, and health care.

Specific recommendations in future policy include: increased stimulation of residence resettlement, increased numbers of temporary work permits, increased in controls for illegal migration, better border control (equipment and training), specific policies directed toward illegal migration employers, specific policies toward official corruption, and new ways to collect data and streamline registration (Chudinovskikh, 2005). 


\section{CHAPTER V}

\section{THE EXPLORATION OF THE RESEARCH QUESTIONS AS APPLIED THROUGH A CROSS CULTURAL COMPARISON}

This chapter will explore one thru six of the proposed research questions with application to the United States, Germany, and Russia. As a review, the proposed research questions to be addressed in this chapter are the following: a) what role do influence groups play on immigration policy in the United States, Germany, and Russia, b) what role do policy changers play on immigration policy in the United States, Germany, and Russia, c) what role do trigger events play on influencing immigration policy decisions in the United States, Germany, and Russia, d) what theories help to inform immigration policy decisions in the United States, Germany, and Russia, e) does the proposed model accurately explain the evolution of immigration policy in the United States, Germany, and Russia and f) does the proposed response continuum aid in understanding immigration policy decisions in the United States, Germany, and Russia?

Although through CLEIM application in Chapters II-IV the elements of influence groups, policy changers, and trigger events were discussed for each separate policy analysis, this chapter will help to note similarities and differences of those specific CLEIM elements by comparing these three elements cross-culturally. The Policy Response Continuum for each of the three countries will be discussed and similarities of policy change will be addressed. A theoretical lens discussion will assist in understanding the different frames of reference that can guide both single policy and multiple policy analysis. An exploration of the effectiveness of CLEIM and the response continuum will provide strengths and weaknesses of the model. Suggestions for future use of CLEIM will be addressed.

The Role of Influence Groups on Policy Decisions 
This section of the chapter will address research question number one, centering on the role of influence groups on immigration policy decisions in all three of the studied countries.

\section{United States and Influence Groups}

In the United States, the CLEIM individual policy analysis provided a connection between influence groups and policy change and showed that this connection is evident throughout history (Daniels, 2004). From the Chinese Exclusion Act until the Immigration Act of 1917, anti-Asian sentiment was evident among the status quo as evidenced by the formation of nativist groups, the newspaper focus on the "Yellow Peril", and the changes in laws prohibiting certain rights for individuals of Asian decent. The exclusion of Asians through immigration policy grew more restrictive with the passage of each policy as the worry and fear surrounding this particular group grew. The second large wave of migrants from the South and East of Europe sparked another rise in anti-immigrant sentiment. New nativist groups were formed, such as the Klu Klux Klan, and these status quo groups demanded preference to White Anglo Saxon Protestant immigrants. The response to this demand is evident from the change of quotas from the 1910 census (Immigration Act of 1921) to the 1890 census (Immigration Act of 1924); resulting in virtually no entrants from Southern and Eastern European countries. Immigration policies during World War I, up to and after World War II, resoundingly focused on the suspected inherent inferior nature of the Communist party. As a result, the Smith Act (1940) and the Walter McCarran Act (1952) clearly exhibited the predominant "Red Scare" belief set of the common American citizenry. The "enlightenment" and freedom for choice encouraged during the 1960 s was experienced in the Immigration Act of 1965 . This Act was an attempt to rectify past wrongs by ending discriminatory quotas; thus proposing preference groups based on the needs of the United States. The populace's fears of uncontrolled, undocumented immigration into the United States led to changes of policy in the 1980 s and 1990s. These fear based policies devised strict enforcement of internal and external immigration controls. Undocumented worries exploded into fears based on security after September 11, 2001. The formation of the Department of Homeland Security and the placement of the new immigration division under this department are the most obvious examples of United State's sentiment concerning current immigration policy (Daniels, 2004). 
In recent months, President George W. Bush has supported renewing a guest worker program in the United States. Much debate has transpired between the houses of government, news media, and citizens centering on the pros and cons of such a policy. Bush's proposed policy is not in alignment with the status quo push since September $11^{\text {th }}$ to focus immigration policy on security concerns. In addition, fears of undocumented migration still abound from the 1980 s. The combination of security and undocumented migration concerns are not alleviated by Bush's suggested guest worker program; thus this suggested policy will continue to receive much debate by both the status quo and other policy changers.

\section{Germany and Influence Groups}

In Germany, the analysis of influence groups provided a connection between influence groups and immigration policy is noted as early as 1880 (Bade \& Weiner, 1997). From 1880 until 1913, the German population consisted mostly of Catholic and Protestant believers. Increasing numbers of Jewish believers resulted in anti-Jewish sentiment; sparking German restriction of immigrant labor consisting mostly during this time period of Polish Jews. Anti-immigrant feelings continued to rise during World War I and World War II (Fetzer, 2000). These feelings were restrained at times due to the need for workers to fill open labor market jobs. Strict exit regulations did not allow foreign workers to leave Germany throughout World War I. During World War II, concentration camps housed individuals considered undesirable to the policy changers and to some extent average citizens.

Perhaps the populace's dichotomized feelings of those migrants considered equal versus those considered unequal is most evident when analyzing Germany's aussiedler, gastarbeiter, and auslander law. German citizens welcomed ethnic Germans (aussiedler) as full citizens with the same rights as all other German citizens (Munz \& Ulrich, 1997). In addition, aussiedler were offered help in fully assimilating into German culture. Gastarbeiter did not receive such a welcome in part due to the status quo view of this group as outsiders (Herbert, 1990). This negativity was tempered to some extent by the need for workers to fill open labor market jobs after World War II. Negativity returned as large numbers of Gastarbeiter did not return to his/her homelands as expected but instead remained living and working throughout Germany (Bade \& 
Weiner, 1997). Worries by German citizens of large numbers of non-Germans helped to encourage the official end of Gastarbeiter law in 1973. German citizens' beliefs toward Auslander law is an extension of the previous Gastarbeiter law (Green, 2005). Foreigners are accepted based on German economic need rather than altruistic notions of helping outsiders. This formation of policy fits with the German view of citizenship based on ethnicity. The growing numbers of migrants in recent years has caused a demand for change in the law governing German migration. Germany has attempted to ask for assistance from the European Union without any agreement to burden share. As a result, Germany has responded by implementing the first actual immigration policy in late 2004.

\section{Russia and Influence Groups}

The Russian CLEIM analysis noted a connection between status quo attitudes and policy is noted as early as the completion of World War I (Felshtinsky, 1982). Negative attitudes of Russian citizens toward Jewish minorities increased during this time period. Trotsky implemented the first policy to track migrants through the use of passports and visas during this time known for anti-Jewish sentiment. During the rule of Stalin, groups of ethnic minorities were forcefully deported into the interior of Asiatic Russia (Hingley, 2003). After years of repression during the Czarist and Communist regimes, Russians pushed for freedom in many areas of life. One new area of freedom was the Freedom of Movement Act (1991) stimulated both by citizen's desires and the changes in the European Union consisting of commonality of immigration policy. In the 1990s, Russian immigration laws mirrored the "migrantophobia" of the citizenry by increasing the enforcement of internal and external policy controls (Badyshtova, 2005, p.45). Since the turn of the $21^{\text {st }}$ century, the numbers of migrants, both documented and undocumented, has continued to increase at a drastic rate. Moscow in particular has attempted to find ways to respond to this growing problem. The overriding influences on the population remain centered on those in power and control such as the president, the central bank, the oil conglomerates, and such. As a result, policies in this century have started to focus on controlling undocumented migration to use migration in ways helpful, rather than harmful, to the country (Blagov, 2002).

The Role of Policy Changers on Policy 
The second research question to address involves the role of policy changers on immigration policy in the United States, Germany, and Russia. Investigation of policy changers influence provides a similar picture in all three countries in which the individual in power (i.e. president, chancellor) and his/her belief set influenced policy decisions through influences on other policy changer's ideas, the power to veto bills, and attempts to sway status quo opinions.

\section{United States and Policy Changers}

A selection of some of the most influential United States immigration policy changers include: Theodore Roosevelt, Warren G. Harding, William McCarthy, John F. Kennedy, Ronald Reagan, and George W. Bush.

Theodore Roosevelt's opinion of the United States as a melting pot encouraged acceptance of immigrants considered desirable over those considered undesirable (Zeidel, 2004). This was evidenced by the increasing restriction against Asian populations who were considered unable to assimilate in American culture. Restriction was further encouraged by the Dillingham Commission in which the idea of a quota system was first proposed. The quota system was thought to be an appropriate way to divide the desirable from the undesirable migrant populations. Quotas were started with Warren G. Harding's (1920-1923) passage of the Immigration Act of 1921 which based entrance quotas on the 1910 census.

The war times of World War I and World War II allowed the anti-Communist feelings of McCarthy to dominate policy during this time period (Vought, 2004). Policy from 1940-1965 would remain forcefully focused against communist beliefs. The changes in the Immigration Act of 1965 decreased this obsession with communist worries. It is interesting to note that some questions remain on immigration forms in present day asking about party affiliation for entrants into the United States.

John F. Kennedy's more liberal beliefs surrounding immigration set the basis for the Immigration Act of 1965 signed into law by Lyndon Baines Johnson (Vought, 2004). The end of the quota system was envisioned by JFK before his death and put into place a mere two years later; thus reforming United States immigration policy and setting a precedent still adhered to in the $21^{\text {st }}$ century. 
Policy of the 1980s was influenced by the mistaken assumptions of President Reagan and his cabinet of the numbers of undocumented immigrants. As such, the policies throughout the 1980 s remained focused on internal and external ways to eradicate numbers of undocumented migrants entering the country (Lanham, 2000).

The Presidency of George W. Bush has vacillated between more liberal immigration outlooks to one based on security. Before September 11, 2001, Bush was in talks with Vicente Fox, the Mexican president, to examine the feasibility of broad amnesty for Mexicans residing in the United States. These talks came to a halt with the September $11^{\text {th }}$ tragedy and policy instead moved to focus on security (Daniels, 2004). During the State of the Union address in January 2006, Bush discussed his support of a revised guest worker program. Perhaps the seeming contradictions during Bush's presidency can be attributed to trigger events that have occurred in his presidency (September 11, 2001) or those during the presidency of his father (Desert Storm). In addition, Bush's previous role as governor of Texas, which depends on migrant labor, has helped to shape his more liberal ideas on immigration policy.

\section{Germany and Policy Changers}

The analysis of Germany's first Chancellor after World War II, Chancellor Adenauer, focused German policy changes on returning Germany to the level of a world partner (Turk, 1999). A large part of this was to economically stabilize Germany to former levels in order to compete in the world market. As such, open labor market jobs needed to be filled with workers. This was first started with the passage of aussiedler laws. Of course this was greatly increased by the gastarbeiter law established under Chancellor Kurt Georg Kiesinger. Kiesinger continued to focus on strengthening the economy, increasing employment, and decreasing inflation.

Chancellor Willi Brandt ended the Hallstein Doctrine enabling East and West Germany to begin low levels of migration between the two sides of Germany for the purposes of work and trade (Turk, 1999).

Chancellor Helmut Schmidt (1974-1982) increased the connections between West Germany and the other western European nations for the purposes of economic interconnectivity (Turk, 1999). The auslanderpolitik law during this time helped Germany to set boundaries 
concerning entries and exit into the country during a time of increasing connectivity with the world.

During Chancellor Gerhard Schroeder's tenure in office (1998-2005), he pushed for increasing the connection between Germany and the European Union for a common market (Monar, 1997). Common policy decisions between the EU and Germany led to the establishment of the Maastricht Treaty to agree on immigration policy for all member states (Reerman, 1997). Increased migration, and decreasing EU support, led to the passage of Germany's first migration law, zuwanderungsgesetz, during 2004.

\section{Russia and Policy Changers}

The CLEIM analysis of Russian policy changers is most evident with changes started during Gorbachev's rule. Gorbachev's view of glasnost led to the period known as perestroika in Russia (Hingley, 2003). His liberal view of connections with the outside world helped to support the Freedom of Movement Act (1991) which allowed citizens the ability to move freely in and out of the Russian territories. Changes during this time period were instrumental in providing the ground work for later migration change.

President Boris Yeltsin was considered a reform minded president who attempted to make change even without the support of the government (Remington, 2003). Immigration policy changes supported include: Citizenship Law (1992), Immigration Control Act (1993), and the Law on Entry and Exit (1996). These three policies helped to define the beginnings of immigration policy in the newly formed Russia.

President Putin helped to facilitate reform in the land codes, labor codes, taxation codes, judicial system, and political reform (Hespring, 2003). Changes in these large systems have turned Russia towards further reform that has included immigration policy. Since his presidency, the Law on Judicial Status of Foreigners (2002) and the Migration Regulations (2003) policies have helped to more clearly define entry and exit procedures, numbers of migrants allowed to enter, more effective ways to track migrants, and more efficient ways to ensure timely exit from the country.

Trigger Events: Influence on National and International Situations for Policy Decisions 
The examination of trigger events (research question \#3) on immigration policy decisions in the United States, Germany, and Russia has provided some commonalities in policy changes over time. The majority of the policy shifts have centered on international events that affected individual countries in terms of foreign and/or domestic policy, economic climate, military decisions, and the like. For the purposes of answering this research question, this section will examine the individual country policy changes evident from the following large international events: World War I, World War II, the Cold War, the 1970s OPEC oil crises, the collapse of the USSR, and September 11, 2001. If the international event under study occurred during a time that Germany and/or Russia did not have official immigration policy, the changes within the country will be discussed with the assumption that earlier international events will still shape decisions of later immigration policy.

\section{World War I (1914-1917)}

During World War I, the war machine needed civilian help for the war effort to prove successful (Shevin-Coetzee \& Coetzee, 1995). The power of propaganda was known from presidential campaigns in both the United States and Western Europe. To gather willing civilian workers, individual countries effectively used the media to encourage patriotic feelings of unity while also vilifying the enemy. Civilians were asked to focus every effort on the war by increasing productivity and rationing the use of personal products. As a result, numbers of females and semi-skilled workers filled skilled positions through the effective use of supervision. Individual families rationed goods in the following countries: Germany (1915), France (1917), and England (1918).

Even with all these changes, a collapse in authority occurred in Russia, Germany, and Austria-Hungary as evidenced by strikes and the formation of trade unions as a way to support individual worker's rights. The growing strength of unions increased the power of the middle class especially in Europe. Rebellion in the military was noted in France, Russia, Scotland, and Ireland (Shevin-Coetzee \& Coetzee, 1995).

The growing international discontent led to President Woodrow Wilson, of the Unites States, giving a speech known as fourteen points (January 22,1917 ) in which he called for no 
secret treaties, territory decisions based on national self-determination, disarmament, encouragement of free trade, increasing the role of democracy to encourage mediation rather than war, encouraging international law, and ultimately the creation of the League of Nations (Kegley \& Raymond, 2002). Although some of Wilson's decisions were included in the Treaty of Versailles the main focus was on "retaliation rather than reconciliation" (p.143).

The Treaty of Versailles redrew the map of Europe by reducing the size of Germany, eradicating the Austria-Hungarian and Ottoman Empires, and reshaping Eastern Europe to provide a buffer between eastern and western European nations (Shevin-Coetzee \& Coetzee, 1995). More land was given to France, Denmark, Poland, Belgium, and Lithuania while Germany suffered military occupation and paying war reparations (Kegley \& Raymond, 2002).

German costs of World War I included losing areas of land, financial loss, and the loss of people (Shevin-Coetzee \& Coetzee, 1995). The reshaping of country boundaries forced numbers of the populace to live outside the borders of his/her homelands. The combined effect of the growth of labor unions, discontent with the war, and the decisions included in the Treaty of Versailles encouraged the formation of socialism in both Russia and Germany as a way to alleviate national problems.

International lessons learned through World War I included: economic dependence between the United States and Europe, the strength of state authority, violence as an acceptable way to solve problems, and the ideology of increased levels of national sovereignty by collectivization (Shevin-Coetzee \& Coetzee, 1995).

United States

Three immigration policies followed in rapid succession during or after World War I: the Immigration Act of 1917, the Immigration Act of 1921, and the Immigration Act of 1924 (Daniels, 2004). (See Table 8.) All three of these policies were ways of restricting the numbers of migrants to enter the United States. The Immigration Act of 1917 attempted restriction through imposing a literacy test, creating an Asiatic bar zone, and moving the department concerning immigration from the Department of the Treasury to the Department of Commerce and Labor. The literacy test imposed a class based restriction to allow higher numbers of the elite class rather than the poor 
who were more likely illiterate. Both the Immigration Act of 1921 and 1924 attempted to restrict migration through the institute of quotas. The 1921 act based entrance on the 1910 census and the 1924 act based entrance on the 1890 census. This shift to an earlier census created entrance to Northern and Western Europeans of WASP heritage. This change was quite important as Southern and Eastern Europeans (i.e. Polish, Russians, and some Germans) were virtually excluded from entrance into the United States.

\section{German Discontent}

Following World War I, Germany witnessed an increase in nationalism throughout the 1920 s and 1930s (Kegley \& Raymond, 2002). The root of growing nationalism was based on four factors: beliefs of the unfairness of lost territory created by the Treaty of Versailles, resentment of military occupation and reparations, increasing economic instability, and the belief that a socialistic form of government could alleviate growing country wide problems. The combination of these factors allowed Germany to seek a strong leader who would help to return her to the former glory the country had previously known (See Table 10.)

\section{The Russian Revolution}

Russian support of World War I depleted many of the nation's resources and created discontent among citizens (Adams, 1995). Russia withdrew from World War I and Tsar Nicholas II abdicated after encouragement from the deflated military. The Treaty of Versailles removed Finland, Estonia, Latvia, Lithuania, and parts of Poland from Russian rule. A provisional government was put in place but this newly formed institution was riddled with discontent. In October 1917, the Bolshevik party took power under the leadership of Lenin. Communism was officially instituted in Russia creating effects on both European and world policy in the future due to fear of the spread of communism throughout the world (See Table 10.)

\section{The Great Depression}

Before the Great Depression, the United States, Australia, Canada, and France experienced an economic boom instigated by automobile and electronic appliance sales such as radios, refrigerators, and vacuums (Kindleberger, 1986). In 1929, unemployment in the United States was only $3.1 \%$. Apparently the old saying "what goes up must come down" was played 
out during this time period. Indicators of what was to come were noted as early as 1927 , as the Federal Reserve System decreased interest rates while increasing open market purchases. As credit was overextended, world wide pressure reduced business production which was aggravated by the current world wide agricultural problems. The stock market crash of 1929 was not enough to alone create the Great Depression. The combination of the crash, the agricultural depression, and the monetary collapse (high levels of money withdrawal) led to a halt on industrial production and the reduction of import/export commodity prices.

The Great Depression has been labeled the longest economic downfall in history (Satre, 1995). This particular depression led to world wide devastation due to the United States' financial force throughout the world by war financing as well as exports of oil and coal. In addition, the financial crisis was followed by a massive reduction in production which resulted in high levels of unemployment. As these problems spread throughout the world, the following changes were noted: high unemployment, social and political change, government destruction, and the rise of Nazi power.

Although the world as a whole felt the Great Depression, some countries experienced more difficulty (Satre, 1995). The destruction of the Great Depression was highest in Germany and Austria due to post-war dependence on the United States for rebuilding after World War I. The virtual collapse of the Western European economy was blamed on the Jewish bankers who were seen as escaping from the hardships caused by the depression. France continued to have economic difficulties until World War II. England and the Scandinavian countries were the least effected within Western Europe. The Soviet Union most successfully navigated through the world wide depression due to the policy of collectivization of agriculture.

\section{United States}

Rather than encouraging the passage of new overarching level policies, the Great Depression increased the world wide tensions present after the completion of World War I. In the United States, President Hoover signed an executive order to stop immigration in order to provide open jobs to United States citizens (Graham, 2004). One result of this was the forced deportation of people of Mexican decent to Mexico without regard for the individual's citizenship (Daniels, 
2004). The Bureau of Immigration was officially changed to the Immigration and Naturalization Service to be housed within the Department of Justice thereby shifting the focus of the service to a security, protection, and legalization issue (Briggs, 2003) (See Table 10.)

\section{Germany}

In Germany, the continued anger from World War I combined with the increase in economic failure, led to the rise in power of Hitler and the Nazi party (Satre, 1995). Hitler established a public works system to alleviate massive unemployment and rejuvenate the economy for the purpose of rebuilding the military and rearming Germany. This rearmament was Hitler's plan to expand the borders of Germany throughout much of Europe (See Table 10.) Russia

In Russia, power moved from Lenin to Stalin in 1928 (Hingley, 2003). Stalin's main focus was on ways to increase his own power and control within the country. Although Russia managed to successfully navigate through the problems directly after the stock market crash, a large famine spread throughout the country in 1932-1933. The country was further devastated by the time known as the Great Terror in which Stalin rid the Communist party of rivals for power. As Stalin's power increased, he began to form foreign alliances such as the Soviet-German pact (August 1939) although this pact was later revoked by Hitler's invasion of the Soviet Union (See Table 10.)

\section{World War II (1939-1945)}

At the peak of World War II, fifty six nations were involved in the battle (Thornton, 1995). This war was truly a total war in that countries were required to mobilize their entire resource base through the control of the government. Areas of mobilization include the use of the military, the work effort by civilians on the home front, the use of intellectual knowledge for new warfare techniques, and the effective use of propaganda. Much like during WWI, the propaganda during this war encouraged patriotism, morality, and sacrifice while demonizing Germany and Nazi rule. One difference in the propaganda during this war is use of television as a new vehicle for transmission. In the United States, Hollywood became involved and numerous movies were devised around the theme of war. 
WWII sparked the second "red scare" in the United States and worries surrounding a world communist take over encouraged the country to explore ways to increase national security (Theodoulou \& Kofinis, 2004). Examples of attempts include the McCarthy lists and the use of Japanese relocation camps (Thornton, 1995).

The post war effects created a world of conflict and competition. Conflicts occurred in China, Greece, Vietnam and the Arabs against the Israelis as well as the Indians against Pakistan (Thornton, 1995).Germany was split into four separate sectors under the control of Russia, the United States, France and England. The United States gained power through the United Nations placement in New York City, post-war reconstruction money into Western Europe, and political control of post-war decisions. Russia gained power through shear size and the control of the eastern satellite nations. Two superpowers rose to the top in world power: the United States and Russia.

The conflict and competition focus under girded the aim for international collective security through the formation of the United Nations (UN) of which the security arm was titled the Security Council (Kegley \& Raymond, 2002). In reality, the UN was highly influenced by the superpowers of the United States and Russia. The world retribution mentality for post-WWII encourages a focus on land acquisition as power leading to the battle of the Cold War between the United States and Russia.

\section{United States}

\section{Worker recruitment.}

Immigrants were recruited to fill open jobs in agriculture through the Bracero program (Briggs, 2003). Active recruitment lasted from July 1942-April 1943 with over 4.7 million workers used during the entire length of the program (Briggs, 2003) (See Table 11.)

Smith act (1940).

The Smith Act increased the view of immigration policy into a prosecution type (Daniels, 2004). In addition to visa and photograph requirements, finger prints were now mandatory. Naturalization was further restricted to specifically refuse the process to former Communists. 
Movement of migrants throughout the country required processing of a move form as long as the migrant continued to live in the United States (See Table 11.)

McCarran Walter act (1952).

The McCarran Walter Act continued the use of quotas although allowed numbers would now be based on the 1920 census (Daniels, 2004). This later quota allowed higher numbers of migrants from Northern and Eastern Europe. The Asiatic bar zone was removed allowing for higher numbers of Asian migrants. Skilled workers were more readily granted entrance compared to past policies allowing for the bulk consisting of unskilled laborers (See Table 11.)

\section{Germany}

Aussiedler law.

The end of World War II allowed for the resettlement of ethnic Germans (aussiedler) returning to their German homeland (Munz \& Ulrich, 1997). The majority of ethnics migrated from the lands of Eastern Germany, Poland, Czechoslovakia, Hungary, Yugoslavia, and Russia. The policy was implemented due to: a) the large numbers of ethnic Germans living outside of the country due to World War I and World War II, b) abuse of ethnic Germans during World War II, and c) a form of compensation to German ethnics based on the jus Sanguinis form of citizenship (Ronge, 1997) (See Table 11.)

Arrivals of aussiedler started after World War II and continued into the 1990s with the peak year of entrance occurring in 1990 (Munz \& Ulrich, 1997).

Gastarbeiter law (1946-1973).

Similar to the United States, Germany required immigrant workers to fill open labor market jobs created from World War II (Fetzer, 2000). This was in part due to the West German focus from 1946-1973 on post-war recovery. Policy first centered on labor agreements with specific countries such as Italy, Spain, Greece, Turkey, Portugal, Tunisia, Morocco, and Yugoslavia for workers on a 1 to 3 year rotation. Labor agreements turned into the active recruitment of workers which ended in 1973 in part due to permanent settlement of many gastarbeiters within Germany (Bade \& Weiner, 1997) (See Table 11.)

Russia 
Russian discontent with the western world increased during the post WW \| era. This was in part due to Stalin's view of slow help during the war from allied forces to push the Germans off Russian soil (Hingley, 2003). The Soviet Union maintained control over the eastern portion of Berlin as part of the division of Germany. In addition, Germany controlled seven satellite Eastern European nations: Albania, Bulgaria, Czechoslovakia, Yugoslavia, Hungary, Poland, and Romania (See Table 11.)

\section{The Cold War Years (1946-1991)}

Factors contributing to the start of the Cold War included: the number of World War II casualties, the destruction of Europe and Asia, the shift of power on the international level, and the military strength of the United States and Russia (McMahon, 2003).The USSR wanted to ensure a high level of defense so as to stop future attacks such as those suffered in WWII. The US wanted to ensure "that never again could a hostile state, or coalition of states, be allowed to gain preponderant control over the population, territories, and resources of Europe and East Asia" (p.8).

The underlying ideologies formed through WWII combined with a "mutual mistrust" between the United States and the USSR to ignite the Cold War (Wolf, 1995). The USSR reasons for mistrust included the high losses from WWII, Stalin's militant attitude, and the intent to spread communism outside of the Russian borders (Wolf, 1995). The US reasons for mistrust centered on the worry of USSR expansion based on a communist plot rather than Russian nationalism. President Truman, of the United States, was intently focused on history as a lesson for the future and as such refused to accept totalitarian regimes such as Stalin's from the lessons learned by Hitler's power. The worry in the United States of communist control would continue for over 40 years. Espionage was used by both countries in an attempt to learn state secrets.

Under the Marshall Plan, an economic recovery plan providing money from the United States to Europe, countries with connections to communist based governments could not receive US dollars (i.e. Russian and China) thus in a sense controlling western European economic and political thought (Wolf, 1995) (See Table 11.) 
The focus on the Cold War in Western Europe decreased in the 1950 s due to the proximity to Russian nuclear power, the strength of the Western European economy, and the focus on Southeast Asia through the Vietnam Conflict (Wolf, 1995). Although the United States was also focused on Vietnam, the building of the Berlin wall in 1961 became a vivid reminder of the Cold War and the differences between East and West (Wolf, 1995).

\section{United States}

The Hart-Cellar Act (Immigration Act of 1965) symbolized a shift in United States immigration policy from social reasons to political reasons behind the passage of immigration policy (Briggs, 2003). This policy ended the quota system, placed a cap on western hemisphere migration, and set specific parameters on the types of immigrants wanted (Daniels, 2004) (See Table 11.)

\section{Germany}

Although East and West Germany had been separate since WWII, economic dependence still remained through the exchange of both workers and products. The strain of the Cold War slowly reduced the East-West dependence until the separate states were forced to exist independently after the building of the Berlin Wall in 1961 (Munz \& Ohlinger, 1998). Independence further encouraged the use of migrant labor in West Germany through the gastarbeiter policy as well as the formation of a similar program in East Germany through the recruitment of workers from other Eastern bloc countries and later Cuba, Mozambique, and Vietnam (Munz \& Ulrich, 1997) (See Table 11.)

Russia

The Cold War began to break apart under the rule of Nikita Khrushchev (Wolf, 1995). Khrushchev admitted to past abuses by Stalin and attempted to increase international and domestic policy to move Russia into the modern era. The rule of Gorbachev was ultimately responsible for the official end of the Cold War through his policies of change in strengthening East-West relations (McMahon, 2003) (See Table 11.)

OPEC Oil Crises 
The Organization of Petroleum Exporting Companies (OPEC) crises occurred within the time frame of the Cold War but deserve specific mention due to the literatures target of this event as a specific indicator of immigration policy change (See Table 12.)

In order to understand the formation of OPEC, it is important to know the background information that occurred from 1970-1973 (Clo, 2000). In January 1970, Colonel Muammar Gadhafi, the ruler of Libya, denounced the current oil agreements which had the desired effect of hurting the United States who was highly dependent on oil to function. This event created the cost of crude oil being based on two separate systems: nationalization (Libya, Algeria, Venezuela, part of Iraq) and participation (Saudi Arabia, Abu Dhabi, Kuwait, Qatar, Iran, and part of Iraq). Rather than suddenly regaining control of oil sales as was noted in the example of Gadhafi, participation oriented nations wanted to gradually retain control of oil industries without upsetting the current sales market. Due to this theoretical split, in 1970 OPEC held a conference in the Caracas to address their role as a negotiator between oil companies and member nation's interests. The ultimate outcome was the Teheran Agreements in which OPEC and the oil companies would jointly help determine the sale and distribution of oil.

Two OPEC crises occurred during the 1970s: 1973-1974 and 1978-1979 (Clo, 2000). In the 1973-1974 crises, tension between OPEC and the oil companies led to the market price being above the actual taxed price. Oil host countries demanded to end former agreements and to form new oil contracts. In October of 1973, Egypt and Syria invaded Israel on Yom Kippur and joined with other Arab countries to form the Organization of Arab Petroleum Exporting Countries (OAPEC) in an attempt to stop exports to the United States and Holland due to assistance to Israel perceived against the Arab nations. This move led to decreased oil production pressuring the high rise in prices. Both Europe and Japan were most severely affected creating a massive economic recession.

The OPEC oil crisis of 1978-1979 started with the Arab country focus on conserving oil thereby setting ceilings on production (Clo, 2000). At the same time, Ayatollah Ruhollah Khomeini ascended to power in Iran and attempted to change oil policies. A supply shortage led to an increase in prices which in turn created a recession in oil dependent nations. OPEC failed to alert 
oil receiving nations of the upcoming supply and demand problems resulting in a mistrust of the effectiveness of mediation in the future.

\section{United States}

A debate started in the early 1980s in the United States focusing on the economic nature of immigration both positive and negative due to the recessions of the 1970s (Graham, 2004). Worries turned to numbers of undocumented migrants incorrectly reported by the media (Bean et al., 1990).The media focus helped to encourage prejudice and discrimination by citizens toward migrants (Bohon \& Neal, 2002). The best indicator of prejudice was found to be strength of belief in English Only laws.

Policy in the mid to late 1980 s would use the inaccurate undocumented numbers to write immigration policy based on the following assumptions a) legal migration creates economic advantage and (b) illegal immigration abuses immigration law and the concept of national sovereignty (Laham, 2000).

\section{Germany}

The termination of German guest worker recruitment was directly related to the OPEC oil crisis due to the effect upon the international labor force transitioning from industrialized nations to less developed nations (Munz \& Ulricht, 1997). In addition, technology led to the need for a more highly skilled labor force (Seifert, 1998).

While attempting to make adjustment to the new labor market, Germany experienced a severe recession from 1974-1975 (Munz \& Ulricht, 1997). By the early 1980s, Germany was able to adjust and begin to regain slow economic growth.

Russia

During the world changes created by the dependence on oil, Russia was embroiled in years without change or economic growth (Hingley, 2003). This was in part due to the aging nature of those elite in power. A rapid succession of rulers were in control of the country in which no change or growth was allowed to occur due to the focus of just maintaining and not backsliding through the recessions from both OPEC oil crisis effects.

Collapse of the USSR (1991) 
"We should not forget the Soviet people who were disillusioned and impatient with a corrupt repressive system that refused to acknowledge their humanity." (Ziegler, 1995, p200).

The first economic problems leading up to the collapse of the USSR were noted under the rule of Khrushchev (1953-1964) (Ziegler, 1995). Overall factors that contributed to the collapse include: a) internal problems including economic difficulties, lack of technological advancement, corruption, pollution, and alienation; b) the changes advanced during Perestroika by Gorbachev; and c) the confrontation policies of the United States and President Reagan. These factors were compounded by the unification of Germany and the breakup of the eastern satellite countries. Other USSR states wanted individual national sovereignty rights just as the other Eastern European nations. The incident targeted as the trigger event was the independence of the Ukraine on December 1, 1991. Gorbachev resigned on Christmas Day and the USSR collapse was official started.

United States

After the collapse of the USSR, the world appeared to focus on worry of uncontrolled East-West migration. The United States continued to criminalize undocumented migration with the passage of the Violent Crimes Control and Law Enforcement Act. This act established a criminal alien center that would focus on deportation, passport and visa violations, and external controls. A new "S" visa was established to be used as a way to interrogate witnesses to alleged terrorist activity (Daniels, 2004) (See Table 12.)

Germany

Germany was focused on re-unification during this time period (Turk, 1999). This required merging of East and West German government, economy, industry, taxation, and monetary institutions. Adjustments attributed to violence against foreigners in Saxon-Hoyerswerda, Rostock-Licktenhagen, Hunxe, Molin, Solingen, and Lubeck in which arson, stoning, and encouragement of discrimination by citizens transpired. To decrease the anti-immigrant feelings through incorporation of diverse belief systems, the German government has established a formal way for foreigners to express attitudes on local and national policies (Klopp, 2002). 
Although Germany continued to have the same immigration laws during this time period, the country immigration decisions were in part determined by the participation in the European Union (Monar, 1997). The numbers to Germany are the highest of all other EU nations and as such the country has continued to encourage more stringent internal and external controls throughout the EU as a whole. Congruence of immigration policies was determined by the Maastricht Report (December 3, 1991) (Reerman, 1997). The problem with this report was that it posed many ideas that were only slowly implemented by the EU. Other conferences have continued to address the ever changing migration into and out of the EU. Germany has become increasingly dissatisfied with a lack of burden sharing throughout the member states (Honekapp, 1997).

Russia

Freedom of movement policy.

The Freedom of Movement Policy (1991) allowed for the ability of individual citizens to self-determine their own need for migration, both into and out of the Russian Federation (Dietz \& Segbers, 1997) (See Table 12.)

With the collapse of the USSR, the Russian Federation was faced with a large number of ethnic Russians living outside of the new territorial boundaries (Heleniak, 2004). As a result, the Citizenship Law of 1992 provided official citizenship to all ethnic Russians as well as all Former Soviet Union state individuals in part due to the common Russian language.

Immigration control act.

The Immigration Control Act (1993) established the Federal Migration Service (FMS) to implement all the new Russian Federation migration policies (Heleniak, 2004). Tasks of the newly formed FMS included migration documentation, internal and external controls, refugee and asylee control, and foreign labor control (Chudinovskikh, 2005) (See Table 12.)

The World Rise of Terrorism: September 11, 2001

Crotty (2005) defines terrorism as "extralegal acts of violence directed against civilians (primarily), official, or military targets in an effort to induce fear and disorder into a society in advancing ideological, religious, ethnic, or other agendas" (p.6). On a political continuum, 
terrorism falls at one end of the continuum while democracy falls at the other end of the continuum. In the past, terrorism in the democratic arena has been in the following categories: lone terrorists (i.e. Ted Kaczynski the Unabomber), small groups (i.e. Timothy McVeigh and Terry Nichols in the Oklahoma City bombing) political assassinations (i.e. Martin Luther King), regional secessionists (i.e. South in Civil War), and out of the status quo groups (i.e. Klu Klux Klan). The incident at the world trade center in New York City on September 11, 2001 was not within the world view of former acts of terrorism in democratic societies. A following example occurred on March 11, 2004 with the Madrid, Spain bomb attack on a commuter train. The increasing number of terror attacks in new part of the world, has increased the overall threat level and created a "new world order" in which homeland security is the focus (p.3). In the name of security, international movements are repressed, military is strengthened, and retaliation is deemed important to squash future terrorist attacks. The mantra appears to be something like the end justifies the means necessary to rid the world of terror.

\section{United States}

United States patriot act.

After September $11^{\text {th }}$, the United States passed the U.S. Patriot Act to increase the ability of the government to proactively respond to threats of terrorism. As such, policy in the realms of immigration, banking, and foreign intelligence were reconstructed. Individuals deemed security risks can be obtained using this policy for up to a period of six months without trial (Theodoulou \& Kofinis, 2004).

\section{Homeland security act.}

The Homeland Security Act (2002) dismantled the Immigration and Naturalization Service and reconfigured the components into three separate entities under the Department of Homeland Security: the Bureau of Customs and Border Protection (BCBP), the Bureau of Immigration and Customs Enforcement (BICE), and the Bureau of Citizenship and Immigration Services (BCIS) (See Table 12.)

\section{Germany}


Soon after the events of September $11^{\text {th }}$, the first German immigration law (Zuwanderungsgesetz) was proposed in December of 2001 although it was not officially implemented until 2004 (Green, 2005). Internal German security was one of the areas of much debate in the delay of the policies formation. A new regulatory office, called the Commission for Migration, Refugees, and Immigration, will enforce the new immigration policy. Tasks include deportation, internal and external controls, labor migration, and undocumented migration (See Table 12.)

Russia

The increasing numbers of unknown migrants into the Russian Federation created security concerns (Heleniak, 2002). The Law on Judicial Status of Foreigners (November 2002) established a foreigner registration card for entry and exit from the Russian Federation to better assess who is entering and leaving the country (See Table 12.)

\section{Policy Response Continuum Exploration}

Charting the assigned numbers of the Policy Response Continuum (See Table 1.), throughout the periods studied for the United States, Germany, and Russia conveyed an interesting portrait of policy change of the changes on inclusion versus exclusion over time. An examination of the United States Policy Response Continuum picture (see Figure 5.) showed decisions around the neutral level (in part inclusive and in part exclusive) until the large influx of first and second wave migrants in the mid $18^{\text {th }}$ to early $19^{\text {th }}$ century. The large influx of migrants moved policy from this neutral stage to a highly exclusive stage. As United States policy moved from social reasons for restriction to political and economic reasons for restriction, policy again shifted toward neutral territory perhaps due to the need for workers in specific jobs within the United States. Through the 1980 s and 1990 s, policy has vacillated between neutral to exclusionary depending on the policy examined. Components of recent policies that are less restrictive include: temporary protective status given to those individuals who may be harmed for returning home and increased numbers given to documented status for skilled workers. Exclusionary measures in recent policies include: increased penalties for undocumented 
immigrants, increased penalties to employers of undocumented workers, and increased funding for internal and external controls.

In Germany, the Policy Response Continuum examination showed high levels of inclusion at the beginning of law pertaining to immigration. It appears that Germany immigration law only moved to high levels of exclusion during the 1970 s when large numbers of gastarbeiter continued to remain in Germany after work visas expired. In addition, in 1977, the first comprehensive law for immigration (auslanderpolitik) was written as a result of the gastarbeiter situation and increasing numbers of undocumented migrants residing in the country. The first official immigration policy was a mixture of inclusive and exclusive components causing the Policy Response Continuum to move toward a more neutral level in more recent years (see Figure 6.)

Russian analysis of the Policy Response Continuum is the most severe in nature of all three countries studied. The original 1991 policy was extremely inclusive while policies in the 1990s were increasingly exclusionary. The late 1990 s to present have moved back toward a more neutral policy level (see Figure 7.)

From examining the United States, Germany, and Russia a pattern appears in which all three countries started with policies evident of inclusion. As large numbers of migrants moved into each of the three countries, policy either moved gradually or quite severely to one of exclusion. Over a period of time, policy tended to move toward the neutral arena with components of both inclusion and exclusion included in the policy. It will be interesting to note if this pattern continues as specific countries continue to receive increasing levels of migrants or if perhaps world wide pressures will move policy to an exclusionary period such as that exhibited during the large waves of immigration previously in history.

\section{The Role of Theory to Inform Policy}

Theory applicable to understanding the Cappiccie Lawson Evolution Immigration Model will be applied at the model level. Although theory could also be used to view each individual policy, the model level understanding will help to see the role of theory at an overarching level needed for future cross cultural analysis and international policy agreement. 
To best view CLEIM, the following theories are used: conflict, explanatory immigration theory, structural functionalism, economic, and symbolic interactionism. This section will provide a basic overview of each of these theories and then explore the application to CLEIM.

\section{Basics of Applicable Theories}

\section{Conflict Theory}

At the root of conflict theory is the premise that through struggle and difficulty change is created (Ritzer \& Goodman, 2004). Community or society strengths hold the society together in spite of this struggle during change. One of the factors contributing greatly to conflict is the authority of some people within the society. This natural division creates a tension between those who are in control and those who are not in control. Those in positions of power respond in one of two ways: a) by attempts to stop change to maintain the current structures, or b) attempt to create change based on his/her view for change. As those in power respond, groups of people not in power positions struggle against the power figures response. A key position of conflict theory stresses that conflict may lead to positive changes needed in that specific setting or society. Exploratory Immigration Theory

Exploratory immigration theories include: in-group/out-group theory, group threat theory, and contact theory.

In-group/ out-group theory.

In-group/out-group theory explores the relationship between groups that a person is involved with versus those a person is not involved (Lee \& Ottati, 2002). There is a high correlation between out-group bias and prejudice. Perception is instrumental in determining which groups a person considers different enough to harbor feelings of prejudice or discrimination. A positive relationship exists between in-group cohesion and prejudice to immigrants (Zarate et al., 2002).

Group threat theory.

Quillian's Group Threat Theory (1995) involves the relationship between the immigrant group size (S) and the country's economic situation (E). The level of threat is determined by a complex combination of the immigrant group size and the country's economic situation. This 
theory focuses on macro threat effects perceived by a large group such as a community, a city, a state, or a nation.

To further understand the rising sense of threat, Bachman, Ybarra, and Stephan (1999) explain that threat might involve: realistic threat, symbolic threat, inter-group anxiety, and negative stereotypes. Realistic threat entails occurrences that threaten dominant group existence. Symbolic threats involve diversity of personal characteristics such as morals and values. Intergroup anxiety is influenced by problems such as an antagonistic history, personal contact, level of ethnocentrism, level of difference between out-group and in-group, knowledge concerning the new group, level of competition, and status of the new group. Negative stereotypes increase levels of prejudice and discrimination.

\section{Contact theory.}

Contact theory asserts that lack of intimate contact leads to feelings of prejudice and discrimination. Intimate contact is more than that of a mere acquaintance but instead if defined as contact in which people from the dominant group have close friends from a group different than one's own with contact in the home setting. Contact includes close interactions on a regular basis (i.e. daily, weekly). Contact such as that in a work or school situation where no other time is spent together does not meet the definition of close interaction (McLaren, 2003).

\section{Structural Functionalism}

Structural functional theory (a consensus type theory) spotlights ideas pertaining to the functioning of systems. This perspective promotes that equilibrium is maintained by a systems natural ability to adapt to change over time. As adaptation occurs, the system returns to equilibrium leading to effective functioning of all parts of a system (Ritzer \& Goodman, 2004).

Some considered the positive focus of the structural-functional perspective of systems as unrealistic (Ritzer \& Goodman, 2004). Merton adapted this theory to include negative consequences. The term net balance allows for examining whether the positive outcomes outweigh the negative outcomes of a change. Keep in mind this might depend on who is asking the questions. According to Merton, all decisions have latent (unintended) and manifest (intended) consequences. Both types of consequences should be examined in any change. 


\section{Economic Theory}

Pollack (1995) provides an overview of general economic theory. Income is affected by the gross domestic output of a country (GDP). All workers total income cannot exceed the total GDP. Income is either paid to the worker, paid to bondholders, or leftover in profit. Income is limited by individual worker output. This encourages employers to hire more productive workers. This system is exacerbated by minimum wage, increases unemployment in low skilled workers. Productivity increases as workers sacrifice to increase own personal output in the future. Without such sacrifices, the economy grows, but the rich get richer and the poor poorer. Aggregate demand (what all consumers totaled want to buy in the market) must be high if unemployment rates are low. Another important factor, inflation, plays an inverse role with unemployment.

Economic theory can be broken down into many different types. For the purposes of this analysis, understanding human capital theory and economic segmentation theory are most helpful. Both human capital theory and economic segmentation theory are dominant when discussing employment structure (Thompson \& Gray, 1995). Human capital theory centers on investments (education/training, migration, and new job searches). Laborers attempt to increase investments to obtain better paying jobs. Lack of investment equals lower paying jobs. Dual labor market theory shifts from focus on personal characteristics to large scale economic structures. This theory propagates the economy as a dual market system with the primary market providing higher pay, higher benefits, more stability, and upward mobility and the secondary market providing lower pay, little benefits, less stability, and lack of upward mobility. In order to decrease poverty, people must have access to primary employment. Interaction between these theories transpires as personal characteristics interact with the dual labor market to increase inequality. Rising Inflation leads to primary laborers gaining more wealth as secondary labors become poorer. To emphasize this further, Thompson and Gray (1995) accentuate problems with both theories when specifically discussing minorities, women, and rural area workers (the disadvantaged).

Symbolic Interactionism 
With a symbolic interactionism view, individuals are shaped by interaction with the social environment (Ritzer \& Goodman, 2004). Shaping begins at birth and continues throughout the life cycle. Through social interaction, individuals learn collective meanings, symbols, and appropriate societal behavior. Individual differences in characteristics such as culture, gender, sexual orientation, age, ability, religion, and such shape both individual and collective interpretations of meaning. Collective interpretations, or groups meaning, are understood as a culmination of action oriented decision making and social interaction.

\section{Application of Theories to CLEIM}

The above mentioned theories provide different lenses in which to view CLEIM from diverse points of view. The following section will provide examples of the applicability of these specific theories in relation to immigration theory.

Conflict Theory Application to CLEIM

Conflict theory helps to understand the inherent power differential among groups. In the case of policy change, both influence groups and policy changers hold higher amounts of power and control than the average citizens and substantially more than disenfranchised populations (i.e. poor, minorities, immigrants).

This is further complicated by the fact that policy changers are given legitimate authority by the election that placed him/her in the position of power. The policy changer is supposed to vote as his/her constituency desires but this is not always this case. The policy changer must make voting decisions taking into account the constituency desires, the political climate at the state/federal level, his/her own beliefs on a specific topic, and the position of his/her party position. In the end, the voting outcome many times means little or no attention to the groups in society with the least power.

Typically, influence groups with the most money are able to grow more powerful through the use of lobbying and advertising; thus announcing the view of this group to policy changers in charge of voting on topics. On the other hand, groups without a voice struggle against the dominant powers to be heard. This continued fight by groups of average citizens banding together could create change through the struggle. 
Struggles between national and international immigration policy decisions can be viewed through a conflict perspective. Nations might want to determine immigration policy decisions through a national sovereignty perspective rather than an immigrant human rights perspective suggested by international human rights documents. Or perhaps individual nations are overwhelmed and want assistance from international level boards to handle the influx of migrants. An example of the later is provided by Germany and Austria's struggle to obtain agreement from the European Union to provide burden sharing assistance to other countries due to high levels of migration. The European Union continues to resist this idea while Germany and Austria continue to attempt to receive help with growing numbers entering.

Viewing migration through a conflict perspective aids in understanding the power struggles over immigration policy throughout history between those in authority positions (i.e. influence groups, policy changers, national and international level situations) and the migrant population.

\section{Explanatory Immigration Theories to CLEIM}

According to all three explanatory immigration theories, individuals are shaped by his/her past experience with others similar and different than one's self. Due to the individual being the basic component within the explanatory theories, influence groups and policy changer's ideas of the "other" can similarly influence both the national and international situations.

With in-group/out-group theory, individuals are expected to respond more amicably to those persons within his/her groups of reference (i.e. race, religion, gender). When policy changers are voting on a topic, he/she is voting from within the views of his/her in-group. It would require purposefully thinking of the out-group's experience in order to vote outside of his/her comfort zone. Influence groups are formed through a common set of beliefs and thus by the nature of formation does an in-group unit with difficulty understand the views of the out-group; thus influence groups will support ideas on the basis of in-group beliefs without thinking of the views of the out-group. The shaping of the national and international situation occurs through those biases at the influence group and policy changer level. 
Group threat theory further complicates the examination of in-group/out-group dynamics. According to this theory, negative feelings toward the out-group are expanded as the size of the out-group increases and the economic condition of the area worsens. Fluctuations of the national and international economy (i.e. situation) can affect the policy changer and an influence group's view of the out-group by placing a victim blame mentality on the most powerless groups.

According to contact theory, policy changers and influence groups that live and work among the dominate group without contact with disenfranchised groups naturally have difficulty understanding and relating to such groups. As a result, policies, at the national and international level, are devised and implemented within the framework of the dominant group.

Immigration policies viewed through the lens of an explanatory immigration theory aids in understanding underpinning reasons for policy changes that restrict specific types of migrants based on individual factors different than the in-group characteristics of the policy changers and influence groups that, in part, determine the national and international situation.

\section{Structural Functionalism Applied to CLEIM}

In reference to migration, structural functionalism focuses on the employment capacity needed to maintain a high gross domestic output with low levels of unemployment. Policy viewed from a structural functional perspective will examine the ebbs and flows of the number and types of migrants accepted based on the economic needs of an individual nation or the needs of a group of nations (i.e. European Union). When the need for workers is high, immigration policies liberally allow the type and numbers needed to enter the country or group of countries (i.e. European Union). When the need for workers is low, immigration policies would inhibit migrants from entering the country. Basically, immigration policy decisions from this theoretical lens make decisions based on the national or international needs for increasing or decreasing workers to support the system requirements for balance.

\section{Economic Theory Applied to CLEIM}

An economic theory view examines immigration policy decisions based on ways to strengthen the national or international productivity to encourage massive gross domestic product output. The specific need for types of workers is explained by a type of economic theory known 
as human capital theory based on the premise that a dual labor market economy supports primary and secondary labor jobs. Needs in the primary sector would encourage the creation of immigration policies to allow the entrance of skilled and educated workers. Needs in the secondary labor market would encourage the creation of immigration policies to allow the entrance of unskilled workers. Needs in this theory are based solely on economic gain rather than the efficient functioning of the system as noted in structural functional theory.

\section{Symbolic Interaction Applied to CLEIM}

Symbolic interaction allows for the examination of the unique view of individuals and groups to be analyzed. Policy changers and influence groups are shaped by the environment to make decisions based on the collective meanings that they have learned over time. Similarly, national situations are molded by the collective meanings of a specific culture. Large numbers of migrants into a country can create misunderstandings due to the differences placed on symbols and meaning by various cultures. Comparisons between distinct countries, on the international level of analysis, must use a symbolic interaction frame to examine the cultural differences in collective understanding.

Immigration policy responses to migration are quite different from one society to another in part based on the cultural differences in collective meanings. A concrete example of this is the view of citizenship based on jus sanguinis or jus soli. A country's basis of citizenship shapes immigration policy decisions by determining who is and who is not considered a citizen.

The interpretation of a trigger event is shaped by the national collective meanings derived from a country's unique history. Past experiences such as war, famine, drought, depression, and invasion influence future policy decisions through the shaping of collective meaning.

\section{The CLEIM Analysis}

Analysis of CLEIM must address the following two research question areas: a) the model's accuracy in explaining the evolution of immigration policy in the United States, Germany, and Russia and b) the ability of the proposed response continuum to aid in understanding immigration policy decisions. After a discussion of both of these questions, a specific listing of CLEIM strengths and weaknesses is provided (See Table 13.) 
The proposed Cappiccie Lawson Evolution Immigration Model was successfully applied to immigration policy in the United States from 1882 to the present, in Germany from post-World War II (1945) to the present, and in Russia from post-Communism (1991) to the present. All the elements of the model (trigger events, influence groups, national/international situation, and policy changers) were able to be applied to the policies in this analysis without difficulty. Through the application of the model, policy by policy, CLEIM assisted in understanding the pressures that influence the change of policy over a historical period of time regardless of the culture under study. Due to the ability of CLEIM to discuss individual policy for over a 120 year period (U.S. policy analysis), it is expected that this model will continue to prove useful in the examination of future immigration policy analysis. In addition, CLEIM allowed for a common format in which to examine similarities and differences between three diverse country's immigration policies. It is expected that CLEIM can be applied to any type of governmental structure due to the wide applicability in this study to three diverse countries.

The Policy Response Continuum provided a concrete number to examine the level of inclusion and exclusion per policy as well as similarities and differences between country policy changes. Graphing the countries separately enabled a pattern of change to form in which all three countries moved move inclusion, to exclusion, to more neutral policies over varying amounts of time. (See Figures 5-7.) The ability of CLEIM's Policy Response Continuum to examine long term immigration policy shifts can assist policy changers to understand the long-term effects of individual policy decisions. In addition, implementing future policy decisions using a past understanding of the inclusion/exclusion level and the unintended consequences from these past policies can aide policy changers in writing and implementing future policy free from the past negative consequences for natives and immigrants alike.

From the above discussion, the following strengths are noted: a) application of model elements allows for study of impinging factors that affect writing of policy, b) application of model elements allows for study of impinging factors that affect implementation of policy, c) model usefulness for application to a single policy; d) model usefulness for application to multiple policies over a period of time, e) model usefulness for application to policy cross culturally, f) 
ability to target unintended consequences of policy, g) Policy Response Continuum allows for analysis of policy trends over time by country, h) Policy Response Continuum allows for analysis of policy trends cross-culturally, and i) exploratory analysis of model allows for future longitudinal trend analysis using census data to test model (See Table 13.)

CLEIM has one major weakness (See Table 13.) To apply CLEIM, the researcher must have documentation of the immigration policy specifics, influence groups agendas, policy changer information, national level information, and international level information. Some nations may not have this information readily available for analysis and thus CLEIM cannot be used to analyze countries without the needed information. As such, CLEIM, in its current form, is most useful for analysis in areas with written documentation of the policy history and element information.

\section{Future uses of CLEIM}

Futures uses of CLEIM are divided into two separate areas: a) future research exploration of model and use of the model for analysis and b) writing and implementation of past and future policy.

This study analysis provided the introduction of CLEIM and the exploratory theoretical analysis of the model in the United States, Germany, and Russia. With existing census data in all three of these countries, CLEIM can be analyzed using a longitudinal trend study design. To apply this design, the specific event and resulting policy to be examined will be targeted. Census data numbers from the year before the policy will be gathered. The mean of the immigration numbers from three years succeeding policy implementation will be determined. Examining three years is necessary since change does not occur instantaneously after a public policy is changed. The mean of three years, following policy implementation, will provide a more reliable indicator of the true result of the execution of a new immigration policy. The number changes pre and post policy implementation will be inspected policy by policy over a period of time to ascertain if CLEIM empirically explains policy implementation as well as it has theoretically in this study. It will be necessary to examine one country's immigration policy at a time to tease out the empirical applicability for each country. 
To address future international immigration policy decisions, a tool was needed to examine both separate country policy over time and the similarities and differences of diverse country policy. CLEIM can be used to examine a number of cross-cultural policies to help international boards make informed decisions for future policy. Knowledge of policy history for all nations under that specific international board will be extremely important to ensure policies that will be effective for all countries involved. Policy decisions made from an informed position can only support the possibility of efficient and effective policy free from complete status quo inclinations of the time period.

The Policy Response Continuum portion of CLEIM provides a concrete number helpful in determining if the following or previous policy was more or less restrictive; thus assisting in exploring long term patterns of policy change. Proposed immigration policies can be placed along this continuum to determine the change from the previous policy to determine if the country would be making a more, less, or similarly restrictive policy. Legislative representatives may then choose to vote or not vote for a particular policy from an informed position on the level of inclusion/exclusion.

The future expected increases in migration will continue to tie independent nations together in policy decisions for future immigration policy. CLEIM is a useful tool as a first step analysis of the either one country or the similarities and differences between diverse country immigration policies. A basic understanding of cross-cultural immigration policy will be necessary to implement the future changes needed to meet the needs of future migrant flows while maintaining the functioning of national and international systems. Perhaps as future policies continue to intertwine and world wide events create unity and/or divisiveness, international immigration policy will emerge with similar goals. If social work is willing and able to prepare with suggestions from the following chapter $(\mathrm{VI})$, the profession can be instrumental in the future of immigration policy. 


\section{CHAPTER VI}

\section{SOCIAL WORK PAST: SOCIAL WORK FUTURE}

This chapter will address the research questions centering around the role of social work in the past and future of immigration policy which includes: a) what role did social work have in the past concerning immigration and/or immigration policy in the past, and b) what role can social work play in the future of immigration and immigration policy?

The prevailing belief systems in the late $19^{\text {th }}$ and early $20^{\text {th }}$ century shaped the evolution of the social work profession (Franklin, 1986). Classical theory evolved from the Christian tradition of Calvinism and Protestantism in which the goal of a good life is based on the concept of salvation. Salvation is derived from a life of virtue, piety, and introspection (Greenstone, 1979). Success is achieved through hard work, efficiency, and effort (Greenstone, 1979). Success, marked by material wealth, increases the likelihood to achieve a life of "order and rationality"; thus bringing a person one step closer to a life of salvation (Franklin, 1986, p.506). Secular liberalism is composed of a dichotomy. One side of the dichotomy focuses on the greatest good for the greatest number. The other side focuses on needed social and moral reform to develop personal skills (Greenstone, 1979). Over time, secular liberalism has evolved into an American form of liberalism based on capitalism; resulting on a focus of pleasure seeking behaviors (Franklin, 1986). Gaining wealth and possessions is rewarding and so the basis of hard work is one of self interest. An individual's focus is thus focused on reward for self rather than the human race. Biological Darwinism stresses survival of the fittest. Poverty is viewed as a stage in the evolutionary process of the world. Those that are able to survive poverty and move into more affluent levels of society are more likely to survive and thus labeled more capable. Pragmatism viewed science as the continued quest for knowledge. Knowledge is seen as a continual process 
shaped by the experiences of individuals. The combination of knowledge and that contribution to science will continue to shift and grow over time to lead to higher levels of understanding.

\section{America Adjusts to Change}

Within the framework of the previous belief systems, the United States was faced with three large historical events occurred in the United States from the end of the Civil War until World War I: industrialization, urbanization, and immigration (Kirst-Ashman \& Hull, 2006). Industrialization required large numbers of workers to fill the new jobs created from the movement of a market economy based on agriculture to mechanization. Open job positions acted as a pull factor for rural families to move to the city for employment; thus shifting the population of America from the rural farmlands to the urban centers. Even with the large numbers of American families moving to the city, more workers were needed to fill open job positions. Employers of large industries started to recruit for workers from Europe. The pull factor of available jobs in America along with the push factors in many European countries led to mass immigration from northern and western European countries into the eastern cities of America.

\section{The Focus on Poverty Shifts}

Changes of the late $19^{\text {th }}$ and early $20^{\text {th century }}$ helped to shift the United States view of poverty. During Civil War times, poverty was considered a personal problem (Franklin, 1986). Individuals only need work harder in the agrarian society to live above the level of poverty. In the 1880 s, the beginnings of industrialization and urbanization greatly increased poverty in the United States. As a result, the society was forced to re-consider the prevailing attitude concerning poverty as a personal defect. Could such large numbers of Americans be inherently defective? The large numbers of those in urban poverty created a sense that perhaps anyone could be affected by the ills of this new creature. New beliefs of the roots of poverty were bolstered by the work of Charles Booth (1893) which highlighted poverty as related to the social problems of unemployment, illness, and accidents. Booth's work suggested that poverty was more than a sign of personal failure. 
Through the dual lens of prevailing belief systems of the late $19^{\text {th }}$ century and the shaping of the historical context of the time period, two social work methods emerged to alleviate the plight of poverty (Franklin, 1986). Both models, the charity organizations and settlement houses, were derived from prevalent English methods of easing "pauperism, crime, and mental and physical disabilities that contributed to dependency" (p.508). Although the charity organization and settlement house movements were based on vastly different intervention methods, both movements were committed to helping the disenfranchised populations of society (Kirst-Ashman \& Hull, 2006).

\section{Charity Organization Society}

Charity Organization Societies (COS) were based on a concern for the christianly service to others less fortunate (Franklin, 1986). A "friendly visitor" would visit at the home of a poor individual to provide education in hopes of rehabilitating the individual. The goal was to increase the work ethic and self reliance of those individuals in poverty. The social worker was in the role of the expert providing moral training without enabling the individual (Kirst-Ashman \& Hull, 2006).

This method's goal was to provide "scientifically" based interventions (Kirst-Ashman \& Hull, 2006).Through supervision and solid interventions; the COS hoped to increase the scientific nature of the social work method of intervention, thereby elevating the profession to the same esteemed level with professionals such as medicine and law.

\section{The Settlement House Movement}

Rather than visiting low income neighbors, members of the settlement house movement, moved to live in low income neighborhoods in hopes of alleviating the problems that created poverty (Kirst-Ashman \& Hull, 2006). The workers focused on the self identified problems of the people such as day care, literacy, and citizenship. Social workers used his/her knowledge and positive demeanor to create change. Problems were viewed as rooted in the complex combination of the person in the environment (Franklin, 1986). A complex system of organizations was drawn upon to encompass the holistic nature of the problem (Greenstone, 1979). Interventions were changed as the settlement house workers learned what was most successful. This was especially useful as social workers learned more about cultural sensitivity 
with diverse groups of neighbors. Over time, change at the individual and community level led to macro level social change (Franklin, 1986).

At the basis of the social work role, in the settlement house movement, was empowerment to help individuals realize the unique characteristics and strengths that he/she had to make change on his/her behalf (Kirst-Ashman \& Hull, 2006).

\section{SW and Immigration}

United States immigration parallels the development of social work due to the connections of settlement house work with the growing immigrant population (Borelli, 1975). Although COS worked with immigrants, the literature focuses on the connection between the settlement house movements in beginning work with the immigrant population. Franklin (1986) suggests this connection was based on the plight of immigrants: the poorest living conditions, the levels of disease, the levels of poverty, the lowest wages, and being victims of prejudice and discrimination.

\section{Growth of the Social Work Profession: Leaving out Immigrants}

As social work attempted to shift with the evolution of United States welfare changes, the early work focusing on the immigrant population decreased (Kirst-Ashman \& Hull, 2006). Work in the 1920 s focused on skilled casework with client problems that centered on issues other than poverty (i.e. mental health). This shift in work led to a greater need in MSW level educated social workers. Focus on community organizing and policy work decreased. In the 1930s, the Great Depression resulted in social services moving from private to public service provision. As a result, the public sector offered different types of jobs to social work professionals through the implementation of the Social Security Act. Numbers of BSW level social workers were needed to provide federal level services to the poor. Friction between MSW and BSW trained social workers resulted in social work organizations refusing to deem the BSW level trained social worker as official social work professionals. During World War II, the economic boom of the 1940 s and 1950s, pushed social back into the realm of casework and psychotherapy services. The social change of the 1960 s and federal anti-poverty campaigns that employed large numbers of social workers changed the individual focus of the profession to a macro/administrative level. MSW 
schools of social work responded by devising specialized macro tracks in administration. The government wanted accountability for effective service provision. The Council on Social Work Education (CSWE) formed, in 1952, and created curriculum and accreditation standards. The different roles of BSW and MSW trained social workers were defined. In 1955, seven social work organizations united to form the National Association of Social Workers; accepting both BSW and MSW trained social workers as professionals. In 1974, CSWE established the BSW level as generalist practice and the MSW level as specialized training.

\section{New Trends: Recent Portrait of Social Work}

To focus on the move from the social work profession away from immigrant based services, Feldman (1998) reviewed seventy four articles in the Journal of Social Work Education. Of these articles, no references were made to immigration or immigration policy. Feldman (1998) asserts that the evolution of the social work profession has decreased the transmission of the necessary knowledge base needed to equip social workers for practice with the diverse immigrant populations in the areas of practice, research, and policy.

In the recent years some social work with the immigrant population has started. Humphries (2004) notes a shift from welfare work with immigrants, as was the work in the early $20^{\text {th }}$ century, to a position of power and authority over a vulnerable population. The new social work role centers on "control, restriction, surveillance, and ultimately exclusion" encouraged by federal government policies and procedures (p.94). Social workers increasingly implement federal policies of internal controls that are contrary to client self determination. The role of social workers with the immigrant population is compounded by the media influence of sensationalized reports of the inability to stop undocumented migration. Although social work professionals are supposed to provide unbiased services, the humanness of the workers is affected by media messages. A dilemma is present between the role of the social work professional and the professional code of ethics. 
The shift of social work away from work with immigrant populations is at odds with the increasing numbers of migrants throughout the world. Brubaker (1991) explains current migration in the following way:

International migration and its intricately ramifying networks reach into the most remote regions of the globe, decisively shaping and reshaping the lives, the horizons, and very identities of tens of millions of actual and prospective migrants, as well as the lives, horizons and identities of those whom they encounter at their destinations (p.957). Continued or increased worldwide levels of migration could lead to further strain on developed countries (Brubaker, 1991; Trebicock, 1995). Open immigration countries of the United States, Australia, and Canada are increasingly creating restrictive migration policies due to the numbers of legal and undocumented migrants. In the European Union (EU), increasing numbers of migrants entering Germany and Austria have pressured these countries into setting more restrictive entrance policies then the whole of the EU (Brubaker, 1991).

Plaut (1995) asserts that the $21^{\text {st }}$ century will focus on the increase in the world's population and the increase in migration. As numbers increase, the pressure for global rather than national decisions will increase. The current international conventions and legislation are becoming ineffective against the increasing restriction of migration by developed and underdeveloped nations. Currently, the increasing migration numbers have caused an asymmetrical relationship between policies based on national sovereignty and those based on individual immigrant rights.

\section{Reasons for Increasing Migration}

Basic reasons for the increases in global migration are based on: a) push factors of developing and underdeveloped nations, b) pull factors of developed nations, c) connections of social and economic factors between host countries and receiving countries, and d) individual migrant reasons for migration (Massey, 1999). Current developing and underdeveloped country push factors include depressed wages, chaotic environments, changing government structures, changing people in power positions, current or previous discrimination, and environmental decline (i.e. pollution, natural disasters). Pull factors of developed nations include higher wages, family 
reunification, return to ethnic homelands, social service benefits, higher equality in society, and an idealized notion of the host country. Connections between countries are increasing in this world of globalization. Advances in technology, transportation, computerization and foreign political and trade agreements are part of the picture. In addition, humanitarian aide and military maneuvers bring societies in touch that might not have otherwise been as highly connected. The individual migrant reasons for migration are as numerous as the number of individuals who choose to leave a country and move to another. Reasons are also difficult to pinpoint due to the complex nature of intertwining push and pull factors that create the decision to move.

\section{Policy Decision Concerns}

With the continued pressure of migration, governments are struggling with the direction for immigration policy decisions. Direction can be based on either national sovereignty or individual immigrant rights. Restrictive policies focus on national responsibility while less restrictive policies focus on individual human rights (Carens, 1996). The basic human rights argument involves the moral obligation to allow individuals the ability to choose migration. This notion of basic human rights started with the United Nations Universal Declaration of Human Rights (1948) and later the Helsinki Accords (1975). Both of these ground breaking declarations call for the universal right to immigration. Building upon these declarations, the international community agrees that individual governments might determine whom to admit, the numbers to admit, and whom to grant citizenship. Restrictive entry is understandable to maintain control over the country's populace, provide social services, ensure job allocation, and assist the country's poor. The national sovereignty argument concerns the right of a country to determine what is beneficial for the populace before providing for non-native members. National sovereignty can lead to migration selection in which preferential treatment determines selection of immigrants for entrance by certain skills, education levels, local relationships, and financial resources. Even with this universal understanding, Weiner (1996) asserts the debate arises between those who support basic human rights and those who support national sovereignty. The lens through which public opinion and policy are derived is placed through one of these two filters in considering attitudes toward immigrant populations. 
Seidman (1995) reports that the difficulty in finding a policy balancing national sovereignty and individual rights centers on two difficulties: (a) a lack of support to discuss altruistic and universalistic notions in reference to immigration policy and (b) the reality of the limitations of caring for those we consider as outsiders. According to Carens (1992), these two difficulties are compounded by the fact that individuals in need of the greatest help reside outside the borders of the affluent nations. We are not forced to look directly at the hardships faced by those in other countries by any means other than the occasional glimpse on a television program. The old adage of "out of sight out of mind" seems to truly play a part in developed nation's decisions of whom and how to help other nations.

The debate is further complicated by combining an ethical problem with a political decision. At the root of the ethical problem lies the decision to help or not help outsiders. The ethical decision cannot be made without the filter of the political process. Milligan (1989) suggest three principles to combine ethics and policy: (a) recognizing the national right/need to regulate immigration to protect resources, employment, and the newcomers difficulty in social adjustment, (b) realizing politicians and administrators make decisions based on what is best administratively by using their own moral principles guides, and (c) understanding that citizens of the host country do not consider improving quality of life as a reason to apply for immigration status.

\section{Future Ways to Alleviate Migration Troubles}

Mills (1998) predicts that traditional state sovereignty will continue to decay leaving a new sovereignty that will focus on global concerns. This new sovereignty will continue to gain strength as the interconnectivity of the global economy increases. Yack (2001) terms the future of sovereignty "constituent sovereignty" in which the power is in the hands of the international people and not those rulers and authority figures in control or separate states. Mills (1998) suggests that the new sovereignty will recognize individual rights, group interests, global interests, obligations to states, and obligations of international communities to the rights and responsibilities of individuals and nation states. The inherent power and authority in the new sovereignty must involve a large value base that is flexible and not absolute.

Global Migration Boards 
The difficulty in this change will center on deciding who will regulate global government boards. As nations begin to believe in the idea of a new sovereignty, Freeman (1995) suggests the formation and implementation of a single model of immigration policy for all immigrant receiving nation states. This policy must have the values of toleration, civility, and mutual respect as core components (Sandel, 1998). Perhaps as Forsythe (1998) suggests, the supranational court of the European Union might set precedent for the court of the future.

Wilkins (2002) suggests using the European Court of Human Rights (ECHR) as a model for international court of human rights due to the focus on human rights issues through the lens of sovereign states' traditions. The ECHR enables individuals to appeal for personal rights violations. Individual persons may appeal to the ECHR after ruling out all other means (for example the Supreme Court in the United States). The ECHR uses the margin of appreciation doctrine which allows for national decisions if no universal ruling prevails. Five methods to make decisions are used: text meaning, text history, autonomy convention and court, dynamic method (changing circumstances), and teleological (goal/purpose of convention). National decisions are superseded by international decisions. If ECHR decisions are not followed, nations risk being kicked out of the international community or sanctioned. This is quite different from the United Nations in which the power to sanction is not present.

In order for an ECHR model to work, all member nations would have to agree and fully accept the United Nations Universal Declaration of Human Rights (1948) and the Helsinki Accords (1975). A current example of the need for complete acceptance is provided by the United States current stance (Forsythe, 1998). Although the United States was involved in both the Universal Declaration (1948) and the Helsinki Accords (1975), the nation continues to not accept the parts of the declaration known as the Covenant on Economic, Social, and Cultural Rights and the American Declaration on the Rights and Duties of Man. It is suggested that this refusal is mostly due to the use of the death penalty as punishment for crime. For a world court to function effectively, all nations must agree to basic principles as well as to support the power of international decisions over national decisions (Forsythe, 1998).

World Wide Agreement of Beliefs 
Trebikock (1995) suggests several ways to offset the increasing demands of the worlds' migrants. Suggestions include: free democratic nations increasing international cooperation, implementing more policies concerning human rights violations, increasing liberal trade policies toward developed countries, increasing foreign aide to national disasters, and increasing foreign sanctions to corrupt and incompetent governments.

Whitman (1996) suggests that peace in the new sovereignty can be maintained by all nations accepting six basic beliefs: (a) states are legally equal, (b) all states have equal rights, (c) all states respect the legal entity of the other states, (d) state territories are independent politically, (e) each state develops its own political, social, economic, and cultural systems, and (f) an international obligation focus leads to peace.

\section{Our Individual Part in Future Migration}

Beyond national changes, Nagel (1991) suggest that every individual must question his/her own personal struggle between individualism and empathy. Until all peoples in affluent nations examine own beliefs concerning the alleviation of inequality and suffering in the world, individuals will continue to isolate selves from the ugly realities of our globe.

According to Nino (1991), those fortunate enough to live in affluent nations must decide whether to follow moral knowledge or moral decisions. Moral knowledge involves familiarity with what is morally correct and just, but does not include an action component. A person knows the difference between what is just and what is not just. Moral decision making includes moral knowledge but goes a step further by asking us to act on what we know to be good and just. Nino (1991) asserts it is not enough to allow ourselves to stay separate from these complex issues, but instead calls each of us to make decisions directly.

\section{Social Work: An Answer to Filling the Gap for Future Migration}

The social work profession must be prepared to intervene in migration difficulties at the practice, education, and policy levels (Feldman, 1998). At the root of all three levels must be the following guidelines: a) refusal of social workers to participate in jobs that encourage alienation and marginalization of humankind, b) increasing levels of knowledge on theories of power, c) questioning motives and ideological values behind social policies, d) focusing on questioning 
what works and why it works, e) returning to the social work basis of caring, and f) increasing social justice through the advocacy role. All of these suggestions must start at the level of social work education both by professor example and by safe classroom experiences to learn and practice tasks.

\section{Three Tier Approach to Social Work Change}

To increase the involvement of social workers in current migration and migration policy, three tiers must be addressed: preparation, implementation, and evaluation. The preparation phase includes: a) elevating the importance of work with migrants and the policy effecting migrants and b) devising a plan of intervention. The second tier, implementation, entails applying the devised plan through objectives to reach the ultimate goal of social work involvement in migration and migration policy decisions. The last tier, evaluation, is necessary to determine if the plan is working appropriately. This entails ensuring that goals and objectives are met efficiently and effectively. If it is determined that the plan needs changing, readjustments can be made to increase the effectiveness.

The changes that need to occur within social work are supported both by the Council on Social Work Education (CSWE) and the International Federation of Social Work (IFSW). In fall of 2005, the CSWE social work congress met to set goals for social work education in the next decade (CSWE Online). Of the twelve goals set, four are related to work with diverse groups of disenfranchised people. IFSW promotes goals that enhance the quality of life for people of all nations to include immigrant and refugee populations.

While supports by national and international boards of social work are important, social work needs a plan of action to intervene at the preparation, implementation, and evaluation stage. The author will suggest a plan to incorporate the social work profession at the levels of practice, education, and policy in relations to migrants and migration policy.

The first tier, preparation, will be addressed with suggestions at all three levels of practice, education, and policy. (See Table 14.) At the level of practice preparation, the following are ideas: a) to increase practitioner micro level skills with diverse populations (including information on immigrants and refugees) through mandating diversity continuing education units 
(only now in Alaska and Vermont), b) increase the number of cultural competence questions on licensure exams at all levels (BA, MSW, and Clinical level), c) encourage individual practitioners to reassess level of cultural competence regularly, d) increase the number of continuing education offerings in cultural competence and specific immigrant and refugee courses, e) require practitioners to mark on insurance forms areas of expertise in cultural competence (much like areas of expertise now) to encourage learning more in this field. At the level of education preparation, the following are ideas: a) mandating diversity courses to include a section on immigrants and refugees, b) infusing immigrant and refugee information in all curriculum (BA and MSW), c) schools of social work providing electives on topics such as work with immigrants and refugees (micro), immigration policy domestically, international immigration policy, social welfare systems internationally, d) increasing student exchange opportunities, and e) increase specialization programs in the area of international social work. At the level of policy, the following are ideas: a) increasing the preparation of MSW level social workers to analyze policy, b) increase BSW and MSW level opportunities for advocacy as practice at encouraging social justice, c) providing more practicum placements that combine micro and macro skills to enable social work students involvement at the policy change level for a specific client population, d) encourage social work professionals to become more involved on membership boards in their community, and e) increase the professional acceptance of all ways of knowledge acquisition as equally important (quantitative, qualitative, and theoretical).

The suggested plan for the second tier, implementation, is also applied to the levels of practice, education, and policy in relation to migrants and migration policy (See Table 15.) At the tier of implementation the following are practice ideas: a) professional social workers continuing to study diverse groups, b) professional social workers studying languages of clients in own area of practice, c) involvement in community organizing of migrant populations in local/state area, and d) involvement in grass level change organizations. At the level of education implementation the following are ideas: a) conducting qualitative, quantitative, and theoretical research on migration topics, b) apply for federal/state/and foundation grants on migration research, c) present professional presentations on migration topics, and d) submit publications on migration topics. At 
the level of policy implementation the following are ideas: a) involvement at local, state, and federal boards relating to migration, b) advocacy at the local, state, and federal level to influence policy decisions, c) presenting research knowledge beyond professional articles and presentations to policy makers at state, local, and federal levels

At the evaluation tier, it is important to track the success of a chosen implementation route. Although this is easy at the research level, change at the practice and policy levels are more difficult to measure.

If the social work profession starts the suggested preparation and implementation level changes suggested in this study, the profession will be poised to help with migration woes of the future. Increased work with this population can allow the social work profession to return to the roots started with the charity organizations and settlement house movement in working with vulnerable, underserved immigrant populations.

The lives of Jane Addams, Emily Greene Balch, Crystal Eastman, Florence Kelly, and Grace Abbot inspired the following quote that provides an appropriate way to end a document concerning immigration policy.

"Their lives and their words reaffirm the principle that individuals have obligations to a community of humankind that can take precedence over insularity and fear" (Sullivan, 1993, p.520). 


\section{REFERENCES}

Adams, B. (1995). Interpretive essay. In Events that changed the world in the $20^{\text {th }}$ century by F. Thackeray \& J. Findling (Eds.). Westport, Connecticut: Greenwood Press.

Alba, R., Handl, J., \& Muller, W. (1998). Ethnic inequality in the German school system. In Paths to inclusion: The integration of migrants in the United States and Germany. Eds P. Schuck \& R. Munz. New York: Berghahn Books.

Anderson, J. (2005). Germany and Europe: Centrality in the European Union. In The member states of the European Union. By S. Bulmer \& C. Lequesne. Oxford: Oxford University Press.

Ardittis, S. (1995). Exchange of experience between the Russian Federation and the Southern European regions in the field of migrant reintegration policy. International Migration Review, 29(4), 1049-1056.

Averre, D. (2003). Transborder security and regionalism. In G. Herd \& A. Aldis (Eds.), Russian regions and regionalism: Strength through weakness. New York: Routledge Curzan.

Bade, K.J. \& Weiner, M. (1997). Migration past, migration future: Germany and the United States. Oxford :Berghahn Books.

Badyshtova, I. (2005). Attitudes of the local population toward migrants. Social Research, 44(1). $26-46$. 
Barbieri, W.A. (1998). Ethics of citizenship: Immigration and group rights in Germany. London: Duke University Press.

Baubock, R. (1996). Cultural minority rights for immigrants. International Migration Review, 30(1), 203-250.

Baumgartner, F.R. \& Jones, B.D. (1993). Agendas and instability in American politics. Chicago: University of Chicago Press.

Bean, F.D., Edmonstron, B., \& Passel, J.S. (1990). Undocumented migration to the United States: IRCA and the exploration of the 1980s. Washington: The Urban Institute.

Berger, P. (1945). National sovereignty and world unity. Thought: Fordham University Quarterly, $45(20), 607-627$.

Birkland, T. A. (2001). An introduction to the policy process: Theories, concepts, and models of public policy making. New York: M.E. Sharpe, Inc.

Blumer, H. (1990). Industrialization as an agent of social change: A critical analysis. In David R. Maines \& Thomas J. Morrione (Eds). New York: Aldine de Gruyter.

Borelli, K. (1975). The implications of the new ethnicity for American social work. International Social Work, 18(4), 1-9.

Briggs, V.M. (2003). Mass immigration and the national interest: Political directions for the new century. New York: M.E. Sharpe. 
Brubaker, R. (1991). International migration: A challenge for humanity. International Migration Review, 25(4), 946-957.

Buse, D. (2005). The regions of Germany: A reference guide to the history and culture.

Westport, Connecticut: Greenwood Press.

Carens, J.H. (1995). Immigration, welfare, and justice. In W.F. Schwartz (Ed.), Justice in Immigration (p. 1-17). NewYork: Cambridge University Press.

Carens, J.H. (1996). Realistic and idealistic approaches to ethics of migration, International Migration Review, 30(1), 156-170.

Chandler, C.R. \& Tsai, Y. (2001). Social factors influencing immigrant attitudes: An analysis of data from the general society survey. The Social Science Journal, 38, 177-188.

Chavez, L.R. (2001). Covering immigration: Popular images and the politics of the nation.

Berkeley: University of California Press.

Chudinovskikh, O. (2005). Migration policies in the Russian Federation. Retrieved January 28, 2006, from Moscow State University Web site:

www.unece.org/stats/documents/2005/o1/migration/18.e.ppt.

Churgin, M.J. (1996). Mass exoduses: The response of the United States. International Migration Review, 30(1), 310-324.

Citrin, J., Green, D.P., Muscle, C., Wang, C. (1997). Public opinion toward immigration reform: The role of economic motivation. The Journal of Politics, 59(3), 858-881. 
Citrin, J., Haas, E.B., Musle, C., \& Reingold, B. (1994). Is American nationalism changing? Implications for foreign policy. International Studies Quarterly, 38(1), 1-31.

Clo, A. (2000). Oil economics and policy. Boston: Kluwer Academic Publishers.

Coleman, J.L. \& Harding, S. (1995). Citizenship, the demands of justice, and the moral relevance of political borders. In W.F. Schwartz (Ed.), Justice in Immigration (p. 18-62). NewYork: Cambridge University Press.

Colton, T., \& McFaul, M. (2003). Putin and democratization. In D. Herspring (Eds.), Putin's Russia: Past imperfect, future uncertain. New York: Rowman and Littlefield Publishers, Inc.

Cornelius, W.B. \& Rosenblum, M.R. (2005). Immigration and politics. Annual Review of Political Science, $8(1), 99-119$.

Coulloudon, V. (2003). Putin's anti-corruption reform. In D. Herspring (Eds.), Putin's Russia: Past imperfect, future uncertain. New York: Rowman and Littlefield Publishers, Inc.

Cremer, H. (1998). Internal controls and actual removal of deportable aliens: the current legal situation in the Federal Republic of Germany. In Immigration controls: The search for workable policies in Germany and the United States by K. Hailbronner, D. Martin, \& H. Motomura. Oxford: Berghahn Books.

Crespi, I. (1997). The public opinion process: How the people speak. New Jersey: Lawrence Erlbaum Associates, Publishers. 
Crichlow, R. S. (2002). The impact of individuals on foreign policy decision making. Dissertation Abstracts International: Section A: Human and Social Sciences, 82(10-A), 3560.

Crotty, W. (Eds.). (2005). Democratic development and political terrorism. Boston: Northeastern University Press.

Daniels, R. (2004). Guarding the golden door: American immigration policy and immigration since 1882. New York: Farrar, Straus and Giroux.

DeSipio, L. \& De la Garza, R.O. (1998). Making America, remaking America: Immigrants and immigration policy. Boulder, CO: Westview Press.

Dietz, B., \& Segbers, K. (1997). Policy toward Russia and the other successor states. . In R. Munz \& M. Weiner (Eds.), Migration, refugees, and foreign policy. Oxford: Berghahn Books.

Doob, L.W. (1948). Public opinion and propaganda. New York: Henry Holt and Company.

Dornis, C. (1997). Migration in the Russian Federation since the mid-1980s: Refugees, immigration and emigrants. In R. Munz \& M. Weiner (Eds.), Migration, refugees, and foreign policy. Oxford: Berghahn Books.

Douidic, J.F., Jackson, L.M., \& Armstrong, T.L. (2001). The immigration dilemma: The rate of perceived group competition, ethnic prejudice, and national identity. Journal of Social Issues, 75(3), 389-412.

Du Toit, B.M. (1970). Afrikaners, nationalists, and apartheid. The Journal Modern African Studies, 8(4), 531-551. 
Espenshade, T.J., Baraka, J.L., \& Huber, G.A. (1997). Implications of the 1996 welfare and immigration relief act for United States immigration. Population and Development Review, 23(4), 769-801.

Esses, U.M., Douidic, J.F., Jackson, L.M., \& Armstrong, T.L. (2001). The immigration dilemma: The rate of perceived group competition, ethnic prejudice, and national identity. Journal of Social Issues, 75(3), 389-412.

Fassman, H., \& Munz, R. (1992). Patterns and trends of emigrational migration in Western Europe. Population and Development Review, 18(3), 457-480.

Feldman, R. (1998). Catch the wave. Journal of Social Work Education, 34(2), 1043-1045.

Felshtinsky, Y. (1982). The legal foundations of the immigration and emigration policy of the USSR, 1917-1927. Soviet Studies, 34 (3), 327-348.

Fetzer, J. (2000). Attitudes toward immigration in the United States, France, and Germany. New York: Cambridge University Press.

Fijalkowski, J. (1993). Aggressive nationalism, immigration pressure and asylum policy disputes in contemporary Germany. International Migration Review, 27(4), 850-869.

Figueiredo, R.J.P., \& Elkins, ZS. (2003). Are patriots bigots? An inquiry into the vices of in-group pride. American Journal of Poligical Science, 47(1), 171-188.

Forsythe, D.P. (1998). Human rights fifty years after the universal declaration. PS Online. www. apsanet.org. 
Franklin, D. (1986). Mary Richmond and Jane Addams: From moral certainty to rational inquiry in social work practice. Social Service Review, 60(4),504-525.

Freeman, G.P. (1995). Modes of immigration policy in liberal democratic states. International Migration Review, 29(4), 881-902.

Freeman, S.J. (2000). Ethics: An introduction to philosophy \& practice. Canada: Wadsworth.

Gans, C. (1998). Nationalism and immigration. Ethical Theory and Moral Practice, 1(2), 159180.

Gieseck, A., Heilemann, U., Von Loeffelholz, H.D. (1995). Economic implications of migration into the federal republic of Germany, 1988-1992. International Migration Review, 29(3), 693-709.

Graham, O.L. (2004). Unguarded gates: A history of America's immigration crisis. New York: Rowman \& Littlefield Publishers, Inc.

Gravil, R. (1985). The Nigerian aliens expulsion order of 1983. African Affairs, 84(337), 523-537.

Green, S. (2004). The politics of exclusion. New York: Manchester University Press.

Green, S. (2005). Immigration and integration policy: Between incremental and non-decisions. In Governance in Germany: The semi sovereign state revised. Ed. Simon Green and William E. Patterson. New York: Cambridge University Press.

Greenstone, J. (1979). Dorothy Dix and Jane Addams: From transcendentalism to pragmatism in American. Social Reform, 53(4), 525-559. 
Hadfield, G.K. (1995). Just borders: Normative economics and immigration law. In W.F. Schwartz (Ed.), Justice in Immigration (p. 201-211). NewYork: Cambridge University Press.

Hailbronner, K., Martin, D., Motomura, H. (1997). Immigration admissions: The search for workable policies in Germany and the United States. Oxford: Berghahn Books.

Heleniak, T. (2002). Migration dilemmas haunt post-Soviet Russia. Retrieved January 28, 2006 , from Migration Information Web site: www.migrationinformation.org/profiles/display.efm? ID $=62$.

Heleniak, T. (2004). Migration of the Russian Diaspora after the breakup of the Soviet Union. Journal of International Affairs, 57(2), 99-117.

Herd, G. \& Aldis, A. (Eds.). (2003). Russian regions and regionalism: Strength through weakness. New York: Routledge Curzan.

Herbert, V. (1998). A history of foreign labor in Germany 1880-1980: Seasonal workers, forced laborers, guest workers. Ann Arbor: University of Michigan Press.

Hingley, R. (2003). Russia: A concise history. London: Thames and Hudson.

Honekapp, E. (1997). German policy toward ethnic German minorities. In Migrants, refugees, and foreign policy: United States and German policy toward countries of origin. Oxford: Berghahn Books.

Humphries, B. (2004). An unacceptable role for social work: Implementing immigration policy. British Journal of Social Work, 34(1), 93-107. 
Jenks, J.W. \& Lauck, W. J. (2003). Policies of other immigrant receiving countries.

Congressional Digest, 2(10/11), 294-296.

Johnson, J.H. Farrell, W.C., \& Guinn, C. (1997). Immigration reformed the browning of America: Tensions, conflicts, and community instability in rnetropolitan Los Angeles. International Migration Review, 31(4), 1055-1095.

Joppke, C. (1999). Immigration and the nation-state: The United States, Germany, and Great Britain. Oxford: Oxford University Press.

Kegley, C., \& Raymond, G. (2002). From war to peace: Fateful decision in international politics. New York: Bedford/ St.Martin's.

Key, V.O. (1958). Politics, parties, and pressure groups ( $4^{\text {th }}$ Ed.). New York: Thomas Y. Crowell Company.

Kindleberger, C. (1986). The world in depression: 1929-1939. Berkeley: University of California Press.

Kipp, J. (2003). Putin and Russia's wars in Chechnya. In D. Herspring (Eds.), Putin's Russia: Past imperfect, future uncertain. New York: Rowman and Littlefield Publishers, Inc.

Kirchler, E. \& Zani, B. (1995). Why don't they stay at home? Prejudice against ethnic minorities in Italy. Journal of Community and Applied Social Psychology,5, 59-65.

Kirst-Ashman, K., \& Hull, G. (2006). Generalist practice with organizations and communities ( $3^{\text {rd }}$ Ed.). London: Thompson Brooks-Cole. 
Klopp, B. (2002). German multiculturalism: Immigrant integration and the transformation of citizenship. London: Praeger.

Koopmans, R. \& Statham, P. (1999). Challenging the liberal nation-State? Post nationalism, multiculturalism, and the collective claims making of migrants and ethnic minorities in Britain and Germany. American Journal of Sociology, 105(3), 652-696.

Korobkov, A., \& Zaionchkovskaia, Z. (2004). The changes in the migration patterns in the postSoviet states: The first decade, Communist and Post-Communist Studies, 37, 481-508.

Kurthen, H. (1995). Germany at the crossroads: National identity and the challenges of immigration. International Migration Review, 29(4), 914-938

Kunovich, R.M. (2004). Social structural position and prejudice: An exploration of cross-national differences in regression slopes. Social Science Research, 33(10), 20-45.

Laham, N. (2000). Ronald Reagan and the policy of immigrant reform. London: Praeger.

Lee, Y.T., \& Ottati, V. (2002). Attitudes toward United States immigration policy: the roles of ingroup and out-group bias, economic concerns, and obedience to law. The Journal of Social Psychology, 442(5), 617-634.

Legal Immigration Report to Congress (1995). U.S. Commission on Immigration Reform. "Legal Immigration: Setting Priorities".

Leiley, R. (1995). Interpretive essay. In Events that changed the world in the $20^{\text {th }}$ century by F. Thackeray \& J. Findling (Eds.). Westport, Connecticut: Greenwood Press. 
Lipman, M., \& McFaul, M. (2003). Putin and the media. In D. Herspring (Eds.), Putin's Russia: Past imperfect, future uncertain. New York: Rowman and Littlefield Publishers, Inc.

Lipset, S.M. (1955). The radical rights: A problem for American democracy. The British Journal of Sociology, 6(2), 176-209.

Lonkila, M., \& Salmi, A. (2005). The Russian work collective and migration of Europe. EuropeAsia Studies, 57(5), 681-703.

Marshall, B. (2000). The new Germany and migration in Europe. New York: Manchester University Press.

Martin, P. \& Straubhaar, T. (2002). Best practices to reduce migration pressures. International Migration, 40(3), 5-23.

Massey, D. (1999). International migration at the dawn of the $21^{\text {st }}$ century: The role of the state. Population and Development Review, 25(2), 303-322.

McCue, C.P. \& Norris-Tirrell, D. (2002). The impact of immigration policy on community: An introduction to the symposium. Policy Studies, 30(1), 53-57.

McMahon, R. (2003). The cold war: A very short introduction. New York: Oxford University Press.

Milligan, C. S. (1989). Ethical Aspects of Refugee Issues and U.S. Policy. In V.P. Nanda (Ed.), Refugee Law and Policy: International and U.S. Responses. NewYork: Greenwood Press.

Mills, K. (1998). Human rights in the emerging global order. NewYork: St. Martin's Press, INC. 
Monar, J. (1997.). Comprehensive migration policy. In Immigration admissions: The search for workable policies in Germany and the United States. Eds K. Hailbronner, D. Martin, \& H. Motomura. Oxford: Berghahn Books.

Money, J. (1997). No vacancy: The political geography of immigrant control in advanced industrial countries. International Organization, 51(4), 685-720.

Monshipouri, M. \& Welch, C.E. (2001). The search for international human rights and justice: Coming to terms with the new global realities. Human Rights Quarterly, 23(2), 370-401.

Motomura, H. (1997). The family and immigration. In Immigration admissions: The search for workable policies in Germany and the United States. Eds K. Hailbronner, D. Martin, \& H. Motomura. Oxford: Berghahn Books.

Moulier-Boutang, Y. \& Garson, J.P. (1984). Major Obstacles to Control of Irregular Migrations: Prerequisites to Policy. International Migration Review, 18(3), 579-592.

Munz, R. \& Ohlinger, R. (1998). Long distance: Ethnic Germans and their immigration to Germany. In Paths to inclusion: The integration of migrants in the United States and Germany. Eds P. Schuck \& R. Munz New York: Berghahn Books.

Munz, R. \& Ulich, R. (1997). Changing patterns of immigration to Germany: 1945-1995 Ethnic origins, demographic structures, and future prospects. In Migration past, migration future: Germany and the United States by K. Bade \& M. Weiner. Oxford: Berghahn Books.

Munz, R. \& Weiner, M. (1997). Migrants, refugees, and foreign policy: United States and German policy toward countries of origin. Oxford: Berghahn Books. 
Nagel, T. (1991). Equality and partiality. NewYork: Oxford University Press.

Neal, M., \& Bohon, S.A. (2003). The Dixie Diaspora: Attitude toward immigrants in Georgia. Sociological Spectrum, 23, 181-212.

Neuman, G. (1998). Nationality law in the United States and Germany: Structure and current problems. In Paths to inclusion: The integration of migrants in the United States and Germany. Eds P. Schuck \& R. Munz New York: Berghahn Books.

Nino, C.S. (1991). The ethics of human rights. NewYork: Clarendon Press.

Noddings, N. (2002). Starting at home: Caring and social policy. Los Angeles: University of California Press.

O'Brien, P. (1992). German-Polish migration: The elusive search for a German nation-state. International Migration Review, 26(2), 373-387.

Oezcan, V. (2004). Germany: Immigration in transition. Migration Information Source: Fresh Thought, Authoritative Date, Global Research. Retrieved on March 13, 2006 from www.migrationinformation.org/Profiles/display.cfm?ID=235

Pettigrew. T.F., \& Meertens, R.W. (1995). Subtle and blantant prejudice in Western Europe. European Journal of Social Psychology, 25, 57-75.

Pieterse, J.N. (2002). Global inequality: Bringing policy back in. Third World Quarterly, 23(6), 1023-1046. 
Plaut, W. G. (1995). Asylum: A moral dilemma. London: Praeger.

Pollack, N. (1995). "The Economic Context of Social Welfare and Social welfare policy: American economic primer." Chicago, III: School of Social Service Administration, University of Chicago.

Quillian, L. (1995). Prejudice as a response to perceived group threat: Population composition and anti-immigrant and racial prejudice in Europe. American Sociological Review, 60(4), $586-611$.

Range, V. (1997). The new labor migration as an instrument of German policy. . In Migrants, refugees, and foreign policy: United States and German policy toward countries of origin. Oxford: Berghahn Books.

Rawls, J. (1999). A theory of justice (revised). Cambridge, MA: Harvard University Press.

Reerman, O. (1997). Readmission agreements. In Immigration admissions: The search for workable policies in Germany and the United States. Eds K. Hailbronner, D. Martin, \& H. Motomura. Oxford: Berghahn Books.

Remington, T. (2003). Putin, the Duma, and the political parties. In D. Herspring (Eds.), Putin's Russia: Past imperfect, future uncertain. New York: Rowman and Littlefield Publishers, Inc.

Ritzer, G. \& Goodman, D.J. (2004). Modern Sociological Theory $\left(6^{\text {th }}\right.$ Ed). Boston, MA: McGraw Hill. 
Rumbaut. R.G. (1994). Origins and destinies: Immigration to the United States since World War II. Sociological Forum, 9(4), 583-621.

Rybakovsky. L. (2005). Russia, it's demographic future, and migration processes. Social Sciences, 3, 56-68.

Rybakovsky. L., \& Ryazantsev. S. (July 2005). International migration in the Russian Federation. Proceedings from the United Nations Expert Group Meeting on the International Migration and Development, Population Division of the Department of Economic and Social Affairs, UN Secretariat: New York.

Sanchez, G.J. (1997). Face the nation: Race, immigration, and the rise of nativism in late $20^{\text {th }}$ century. American International Migration Review, 31(4), 1009-1030.

Sandel, M.J. (1998). Liberalism and the limits of justice. Cambride, MA: Cambride University Press.

Satre, L. (1995). Interpretive essay. In Events that changed the world in the $20^{\text {th }}$ century by F. Thackeray \& J. Findling (Eds.). Westport, Connecticut: Greenwood Press.

Schmid, C. (2003). Immigration and Asian and Hispanic minorities in the new south: Am exploration of history, attitudes, and demographic trends. Sociological Spectrum, 23, 129-157.

Schuck, P. \& Munz, R. (1998). Paths to inclusion: The integration of migrants in the United States and Germany. New York: Berghahn Books. 
Segbers, K. (2001). Actors and interests in a changing Russia. In K. Segbers (Eds.), Post-Soviet patchworks: Actors and sectors in Russia between accommodation and resistance to globalization. Burlington, VT: Ashgate.

Seidman, L.M. (1995). Fear and loathing at the border. In W.F. Schwartz (Ed.), Justice in Immigration (p. 136-146). NewYork: Cambridge University Press.

Seifert, W. (1998). Society and the economy: Integration of foreigners in Germany. In Paths to inclusion: The integration of migrants in the United States and Germany. Eds P. Schuck \& R. Munz New York: Berghahn Books.

Seidman, L.M. (1995). Fear and loathing at the border. In W.F. Schwartz (Ed.), Justice in Immigration (p. 136-146). New York: Cambridge University Press.

Shevin, C., Coetzee, M., \& Coetzee, F. (1995). Interpretive essay. In Events that changed the world in the $20^{\text {th }}$ century by F. Thackeray \& J. Findling (Eds.). Westport, Connecticut: Greenwood Press.

Shevtsova, L. (1992). Part I: Central and Eastern Europe: The twin specters of mass unwanted migration and mass involuntary migration. International Migration Review, 26(2), 241257.

Shih, J. (2002). "Yeah I could hire this one, but I know it's gonna be a problem": How race, nativity, and gender affect employer's perception of the manageability of job seekers. Ethnic and Racial Studies, 25(1), 99-119.

Smith, D.H. \& Herring, H.G. (1924). The bureau of immigration: Its history, actions, and organization. Baltimore: John Hopkins Press. 
Sullivan, M. (1993). Social works legacy of peace: Echoes from the early $20^{\text {th }}$ century, Social Work, 38(5), 513-520

Teitelbaum, M. \& Winter, J. (1998). A question of numbers. New York: Hill and Wang.

Thackeray, F., \& Findling, J. (Eds.). (1995). Events that changed the world in the $20^{\text {th }}$ century. Westport, Connecticut: Greenwood Press.

Theodoulou, S.Z. \& Kofinis, C. (2004). The art of the game: Understanding American public policy making. Belmont, CA: Thompson Wadsworth.

Thompson, A. \& Gray, B. (1995). Employment structure and poverty: theoretical perspectives and conceptual frameworks. American Journal of Agricultural Economy. August.

Thornton, L. (1995). Interpretive essay. In Events that changed the world in the $20^{\text {th }}$ century by F. Thackeray \& J. Findling (Eds.). Westport, Connecticut: Greenwood Press.

Tichenor, D.J. (2002). Dividing lines: The politics of immigration control in America. Princeton and Oxford: Princeton University Press.

Tikhomirov, V. (2000). The political economy of post-Soviet Russia. New York: St. Martin's Press, Inc.

Timmer, A.S., \& Williams, J.G. (1988). Immigration policy prior to the 1930s: Labor markets, policy interactions, and globalization backlash. Population and Development Review, 24(4), 739-771.

Tonk, E. (1999). The history of Germany. Westport, Connecticut: Greenwood Press 
Trebicock, M.J. (1995). The case for a liberal immigration policy. In W.F. Schwartz (Ed.), Justice in Immigration (p. 219-246). NewYork: Cambridge University Press.

Trier, T. (1996). Reversed diaspora: Russian Jewry, the transition in Russia, and the migration to Israel. Anthropology of Eastern Europe Review 14(1). Retrieved on March 13, 2006 from www.candor.depaul.edu/-rrotenbe/aeer/aeer14 1/terier.html.

Vaux, T. (2001). The selfish altruist: Relief work in famine and war. London: Earthscan Publications Ltd.

Vought. H.P. (2004). The bully pulpit and the melting pot. Macon, GA: Mercer University Press.

Weiner, M. (1996). Ethics, national sovereignty, and the control of immigration. International Migration Review, 30(1), 171-197.

Weiner, M. \& Munz, R. (1997). Migration, refugees, and fair politics: Prevention and intervention strategies. Third World Quarterly, 18(1), 25-51.

Weinstock, D.M. (1996). Is there a moral case for nationalism? Journal of Applied Philosophy, 13(1), 87-100.

White, R. (1986). Race relations in the American west. American Quarterly, 38(3), 396-416.

Whitman, J.P. (1996). An end to sovereignty? Journal of Social Philosophy, 27(2), 146-157.

Wikipedia Online (2006). The online encyclopedia. Retrieved January 31, 2006, from http://wnw.wikipedia.com. 
Wilkins, B. (2002). International human rights and national discretion. Journal of Ethics: An International Philosophical Review, 6(4), 373-382.

Wilson, A. (1995). The dongas between Ukraine and Russia: The use of history in political disputes. Journal of Contemporary History, 30 (2), 265-289.

Wittkopf, E.R. (1986). On the foreign policy beliefs of American people: A critique and some evidence. International Studies Quarterly, 30(4), 425-445.

Wronski, I. (2004). The EU and its impact on population mobility and border control in central and eastern Europe. The $14^{\text {th }}$ Bicentennial Conference of Europeanists: Chicago.

Yack, B. (2001). Popular sovereignty and nationalism. Political Theory, 29(4), 517-536.

Yudina, T. (2005). Labour migration into Russia: The response of state and society, Current Society, 53(4), 583-606.

Zanotti, A. (1993). Undercurrents of racism in Italy. International Journal of Politics, 7(2), 173-188.

Zarate, M.A., Garcia, B., Garza, A.A., \& Hitlan, R.T. (2002). Cultural threat and perceived realistic group conflict as dual predictors of prejudice. Journal of Experimental Social Psychology, 40, 99-105.

Zeidel, R.F. (2004). Immigrants, progressives, and exclusion politics: The Dillingham commission 1900-1927.

Zeigler, C. (1995). Interpretive essay. In Events that changed the world in the $20^{\text {th }}$ century by F. Thackeray \& J. Findling (Eds.). Westport, Connecticut: Greenwood Press. 
Zimmermann, K.F. (1995). Tackling the European migration problem. The Journal of Economic Perspectives, 9(2), 45-62. 


\section{APPENDIX A}

\section{Figure 1. Cappiccie Lawson Evolution Immigration Model (CLEIM)}

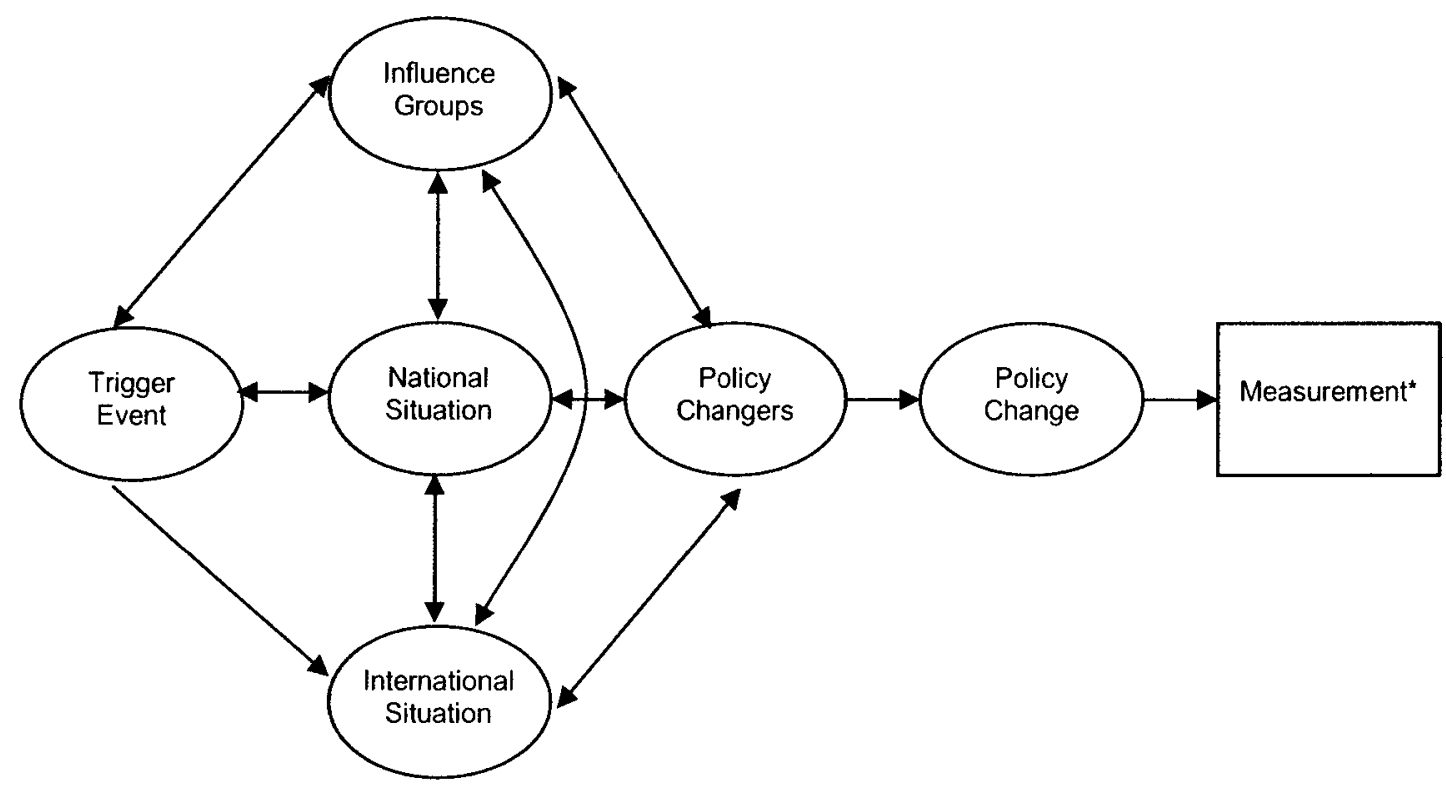

\begin{tabular}{|l|l|}
\hline \multicolumn{1}{|c|}{ Model Element } & \multicolumn{1}{|c|}{ Definition } \\
\hline Trigger Event & $\begin{array}{l}\text { An event that creates change in policy with level of impact determined by causality, } \\
\text { severity, incidence, proximity, and crisis (Theodoulou \& Kofinis, 2004) }\end{array}$ \\
\hline Influence Groups & $\begin{array}{l}\text { A group that influences policy without an official position to write and implement policy } \\
\text { (Birkland, 2001). Examples include interest groups, lobbyists, media, political parties, } \\
\text { and think tanks (Theodoulou \& Kofinish, 2004). }\end{array}$ \\
\hline National Situation & $\begin{array}{l}\text { The "mood" of a nation is set by characteristics such as the government structure, } \\
\text { status quo beliefs, employment level, economic conditions, inflation, and regional } \\
\text { differences. }\end{array}$ \\
\hline International Situation & $\begin{array}{l}\text { The "mood" of the international situation is set by characteristics such as economic } \\
\text { conditions, international policy agreements, legal policy, ethical policy, and monetary } \\
\text { aide (Morishipouri \& Welch, 2001). }\end{array}$ \\
\hline Policy Changers & $\begin{array}{l}\text { Local, state, and national actors who by nature of job influence the writing and } \\
\text { implementation of policy (Birkland, 2001). } \\
\text { Outcome of change explained by CLEIM's Policy Response Continuum of Inclusion } \\
\text { versus Exclusion level }\end{array}$ \\
\hline
\end{tabular}




\section{APPENDIX B}

Table 1. Index of Immigration

\begin{tabular}{|c|c|}
\hline 5 & $\begin{array}{l}\text { Active worker recruitment abroad with advertising and labor } \\
\text { offices; free land or subsidized land purchase; } \\
\text { subsidized/assistance with passage; temporary lodging; free } \\
\text { transportation inland from port of arrival; easy naturalization; } \\
\text { legal property ownership }\end{array}$ \\
\hline 4 & $\begin{array}{l}\text { Free or subsidized land, immigration treaties or contracts } \\
\text { with shipping companies; lodging; worker recruitment; easy } \\
\text { naturalization; legal property ownership }\end{array}$ \\
\hline 3 & $\begin{array}{l}\text { Overseas immigration offices; debarkation coordination; land } \\
\text { designated for settlement; easy naturalization; legalized } \\
\text { property ownership }\end{array}$ \\
\hline 2 & $\begin{array}{l}\text { Overseas immigration offices; debarkation coordination; } \\
\text { easy naturalization; legalized property ownership }\end{array}$ \\
\hline 1 & $\begin{array}{l}\text { Modest advertising; easy naturalization; legalized property } \\
\text { ownership }\end{array}$ \\
\hline 0 & $\begin{array}{l}\text { Open doors; no encouragement; no discrimination or a } \\
\text { balance of pro-immigration and anti-immigration policies }\end{array}$ \\
\hline-1 & $\begin{array}{l}\text { Registration on shipping company and/or contracts for } \\
\text { assistance of passage }\end{array}$ \\
\hline-2 & $\begin{array}{l}\text { Class restriction on immigration (no paupers, potential } \\
\text { wards, or criminals) or selective source entry bans (i.e. no } \\
\text { Asians) }\end{array}$ \\
\hline-3 & $\begin{array}{l}\text { Same as - } 2 \text { plus laws for registration; deportation provisions; } \\
\text { laws restricting property ownership; unenforced selection } \\
\text { laws (i.e. literacy tests) }\end{array}$ \\
\hline-4 & $\begin{array}{l}\text { Destructive quotas; enforced literacy tests; or other } \\
\text { measures designed to decrease immigration significantly }\end{array}$ \\
\hline-5 & Closed (or only slightly ajar) doors, enforcement \\
\hline
\end{tabular}

Note. From Timmer, A.S., \& Williams, J.G. (1988). Immigration policy prior to the 1930s: Labor markets, policy

interactions, and globalization backlash. Population and Development Review, 24(4), 739-771. 


\section{APPENDIX C}

Table 2. Model of Admissions and Rights

Alien Admissions should be:

\begin{tabular}{|c|c|c|}
\hline Alien Rights Should be: & $\begin{array}{l}\text { Expanded/Maintained } \\
\qquad \text { Cosmopolitans } \\
\text { William James } \\
\text { Jane Adams } \\
\text { Edward Kennedy } \\
\text { Xavier Becerra } \\
\text { Immigration Protection League, } \\
\text { American Jewish Committee, Mexican } \\
\text { American Legal Defense and } \\
\text { Education Fund (MALDEF), National } \\
\text { Immigration Forum }\end{array}$ & $\begin{array}{l}\text { Restricted } \\
\qquad \text { Nationalists and Egalitarians } \\
\text { Frederick Douglas } \\
\text { Samuel Gompers } \\
\text { Barbara Jordan } \\
\text { Richard Lamm } \\
\text { AFL (1900-1950), Population Control } \\
\text { and Environmental Groups }\end{array}$ \\
\hline Restrictive & $\begin{array}{l}\text { Free Market Expansionists } \\
\text { Andrew Carnegie } \\
\text { William Howard Taft } \\
\text { Ronald Reagan } \\
\text { Spencer Abraham } \\
\text { American Farm Bureau, National } \\
\text { Association of Manufacturers, CATO } \\
\text { Institute }\end{array}$ & $\begin{array}{l}\text { Classic Exclusionists } \\
\text { Henry Cabot Lodge } \\
\text { Madison Grant } \\
\text { Patrick Buchanan } \\
\text { Peter Brimelow } \\
\text { Immigration Restriction League, }\end{array}$ \\
\hline
\end{tabular}

Note. From Tichenor, D. (2002, p.36). Dividing lines: The politics of immigration control in America. Princeton and Oxford: Princeton University Press. 


\section{APPENDIX D}

Table 3. Magazine Cover Themes by Year

\begin{tabular}{|c|c|}
\hline Year & Theme \\
\hline $1970 \mathrm{~s}$ & $\begin{array}{l}\text { Increased concerns of U.S.-Mexican border; undocumented } \\
\text { migration }\end{array}$ \\
\hline $1980-1985$ & $\begin{array}{l}\text { Undocumented migration, threat of illegal immigrants, } \\
\text { Cuban focus, demographic projections, danger and fear } \\
\text { centering on the economic condition }\end{array}$ \\
\hline $1987-1989$ & Less focus during this two year period post IRCA \\
\hline $1989-1990$ & Refugee numbers \\
\hline $1990-1993$ & $\begin{array}{l}\text { Undocumented numbers of smuggled immigrants, } \\
\text { recession, multiculturalism, race, Hispanic numbers versus } \\
\text { African American numbers }\end{array}$ \\
\hline 1994-1999 & $\begin{array}{l}\text { Death of the nation-state, less positive view of } \\
\text { multiculturalism, exposing falsehoods of liberal ideas, } \\
\text { proposition } 187 \text {, use of welfare by immigrants }\end{array}$ \\
\hline
\end{tabular}

Note. From Chavez, L.R. (2001). Covering immigration: Popular images and the politics of the nation. Berkeley:

University of California Press. 


\section{APPENDIX E}

Table 4. Non-Immigrant Visa Types

\begin{tabular}{|c|c|}
\hline Name of Visa & Type of Visa \\
\hline $\mathrm{D}$ & Foreign crewman \\
\hline $\mathrm{E}$ & Treaty traders and investors \\
\hline $\mathrm{F}$ & Foreign students \\
\hline $\mathrm{H}$ & Temporary workers \\
\hline $\mathrm{H}-1 \mathrm{~A}$ & Non-immigrant workers: nurses \\
\hline $\mathrm{H}-1 \mathrm{~B}$ & Non-immigrant workers: specialty occupations \\
\hline $\mathrm{H}-2 \mathrm{~A}$ & Non-immigrant workers: agricultural \\
\hline $\mathrm{H}-2 \mathrm{~B}$ & Non-immigrant workers: non-agricultural \\
\hline $\mathrm{J}$ & Exchange visitors \\
\hline$L$ & Intra-company transfers \\
\hline $\mathrm{M}$ & Vocational students \\
\hline 0 & $\begin{array}{l}\text { Aliens with extraordinary ability in science, art, education, } \\
\text { business, athletics }\end{array}$ \\
\hline $\mathbf{P}$ & Internationally recognized entertainers and/or athletes \\
\hline $\mathbf{Q}$ & Participant in international cultural exchange \\
\hline $\mathrm{R}$ & Religious workers \\
\hline
\end{tabular}

Note. From Daniel\$ (2004). Guarding the golden door: American immigration policy and immigration since 1882. New

York: Farrar, Straus and Giroux. 
APPENDIX F

Table 5. Media and Economic Connection

\begin{tabular}{|l|l|}
\hline \multicolumn{1}{|c|}{ Date } & \multicolumn{1}{|c|}{ Economic Condition } \\
\hline December 1969-November 1970 & Vietnam War \\
\hline November 1973-March 1975 & Increased inflation; wage price control change; OPEC oil \\
January 1980- July 1980 & money increase \\
\hline July 1981-November 1982 & Increased oil prices and inflation \\
\hline July 1990-March 1991 & Increased inflation and decreased money supply \\
\hline
\end{tabular}

Note. From Chavez, L.R. (2001). Covering immigration: Popular images and the politics of the nation. Berkeley:

University of California Press. 
Table 6. U.S. Policy History and Status Quo Attitudes

\begin{tabular}{|c|c|}
\hline Immigration Law/Time Period & Purpose and U.S. Attitude \\
\hline Late 1850 s- Early 1900 s & Rise of nativist groups to protect WASPS \\
\hline Chinese Exclusion Act (1882) & Laws to stop Asians from owning property, marrying, ect. \\
\hline Gentlemen's Agreement (1906-1907) & Increased restriction of all Asian types; sensational news \\
\hline Immigration Act of 1917 (Burnett Act) & $\begin{array}{l}\text { Literacy test to restrict illiterates, lower numbers of migrants } \\
\text { from South and East Europe }\end{array}$ \\
\hline Immigration Act of 1921 & Previous census data (1910) to further restrict non-WASPS \\
\hline Immigration Act of 1924 & $\begin{array}{l}\text { Previous census data (1890) to even further restrict non- } \\
\text { WASPS }\end{array}$ \\
\hline 1940 s-1950s & McCarthyism and Japanese Relocation Camps, WWII \\
\hline Immigration Act of 1940 & $\begin{array}{l}\text { Focus on subversive nature of immigrants, finger prints, } \\
\text { worry about possible Communists (Reds) in country }\end{array}$ \\
\hline McCarran-Walter Act of 1952 & $\begin{array}{l}\text { Re-codified pervious policy; quota on } 1920 \text { census; } \\
\text { removed Asiatic bar zone; influence of TV, negative focus } \\
\text { on Hispanic immigrants, continued "red" scare time period }\end{array}$ \\
\hline Immigration Act of 1965 (Hart-Cellar) & $\begin{array}{l}\text { Favored particular groups; focus on Civil Rights of Citizens } \\
\text { not immigrants }\end{array}$ \\
\hline Immigration and Reform Control Act (1986) & $\begin{array}{l}\text { Sanctions for employers; focus on undocumented } \\
\text { migration; discrimination against Hispanics }\end{array}$ \\
\hline Immigration Act of 1990 & $\begin{array}{l}\text { Four reasons for immigration: employment, family } \\
\text { reunification, lottery, and diversity; continued focus on } \\
\text { undocumented migration }\end{array}$ \\
\hline Violent Crimes Control and Law Enforcement Act (1994) & $\begin{array}{l}\text { Started alien crime center; strict visa and passport } \\
\text { requirements; economic nature of immigration }\end{array}$ \\
\hline $\begin{array}{l}\text { Illegal Immigration Reform and Immigrant Reform Act } \\
\text { (1996) }\end{array}$ & $\begin{array}{l}\text { Criminalization of undocumented status; increased } \\
\text { deportations; 3-10 yr. restriction for undocumented status; } \\
\text { assumptions all immigrants are illegal }\end{array}$ \\
\hline Homeland Security Act (2002) & $\begin{array}{l}\text { Disbanded INS; } 3 \text { new Bureaus to perform enforcement } \\
\text { and service functions separately; use of immigration law to } \\
\text { hold possible terrorists; discrimination based on race }\end{array}$ \\
\hline
\end{tabular}

Note. From Daniels (2004). Guarding the golden door: American immigration policy and immigration since 1882. New York: Farrar, Straus and Giroux.

\section{APPENDIX H}


Table 7. German Policy History and Status Quo Attitudes

\begin{tabular}{|c|c|}
\hline Immigration Law/Time Period & Purpose and U.S. Attitude \\
\hline Early $19^{\text {th }}$ century & Nationalistic notions of foreigners \\
\hline Late $19^{\text {lin }}$-early $20^{\text {ln }}$ & $\begin{array}{l}\text { Ethnocentrism; negative responses toward immigrants } \\
\text { (especially Jewish individuals) }\end{array}$ \\
\hline $1920 \mathrm{~s}-1940 \mathrm{~s}$ & Rise of Nazi feelings; destruction of "foreign stock" \\
\hline Aussiedler Law (1945) & $\begin{array}{l}\text { Privileged migrants received citizenship; Privileged were } \\
\text { those considered ethnic Germans; assimilation help } \\
\text { offered }\end{array}$ \\
\hline $1940 \mathrm{~s}-1950 \mathrm{~s}$ & $\begin{array}{l}\text { Unofficial EastWest migration; negative feelings between } \\
\text { East/West }\end{array}$ \\
\hline Gastarbeiter Law (1951) & $\begin{array}{l}\text { From 1951-1973 guest workers allowed to fill labor gaps; } 1 \\
\text { to } 3 \text { year rotation; workers did not truly return home }\end{array}$ \\
\hline Berlin Wall (1961) & Unofficial East/West migration stopped \\
\hline EU Formation (1991) & $\begin{array}{l}\text { EU level immigration policy decisions; movement of people } \\
\text { through EU freely until German asked for burden sharing } \\
\text { help without success; limitations of new entrants placed at } \\
\text { that time }\end{array}$ \\
\hline Zuwanderungesetz (2004) & $\begin{array}{l}\text { Increased regulation by Office for German Migration; } \\
\text { increased deportation; focus on undocumented numbers }\end{array}$ \\
\hline
\end{tabular}

Note. From Munz, R. \& Ulrich, R. (1997). Changing patterns of immigration to Germany: 1945-1995 Ethnic origins, demographic structures, and future prospects. In Migration past, migration future: Germany and the United States by K. Bade \& M. Weiner. Oxford: Berghahn Books \& Green, S. (2004). The politics of exclusion. New York: Manchester University Press. 
Figure 2. Map of Germany

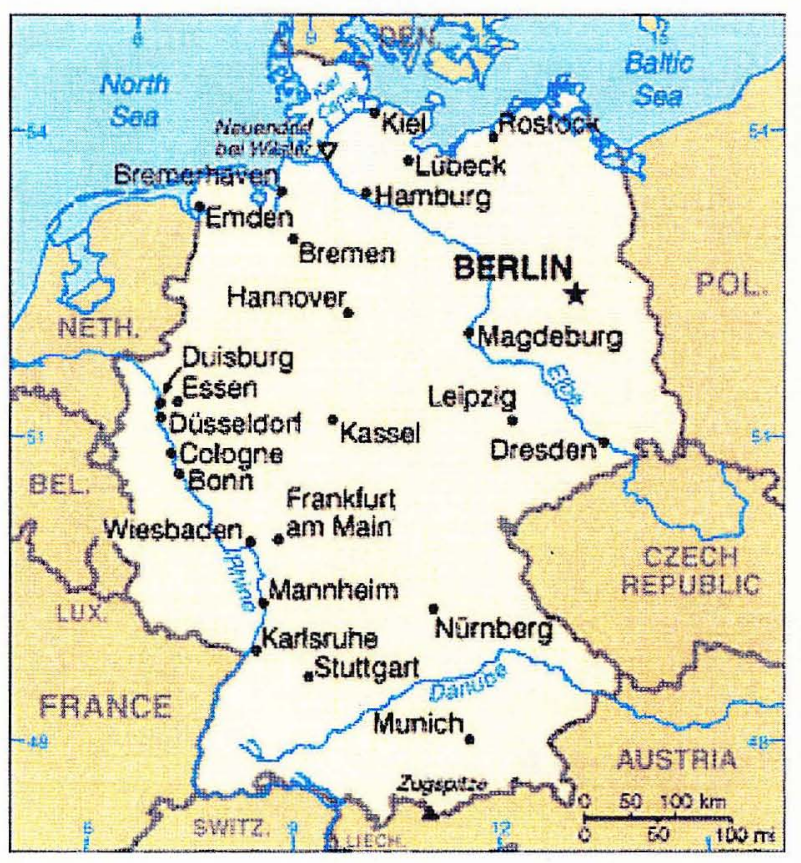

Note. From www.migrationinformation.org 
Figure 3. Subjects of the Russian Federation

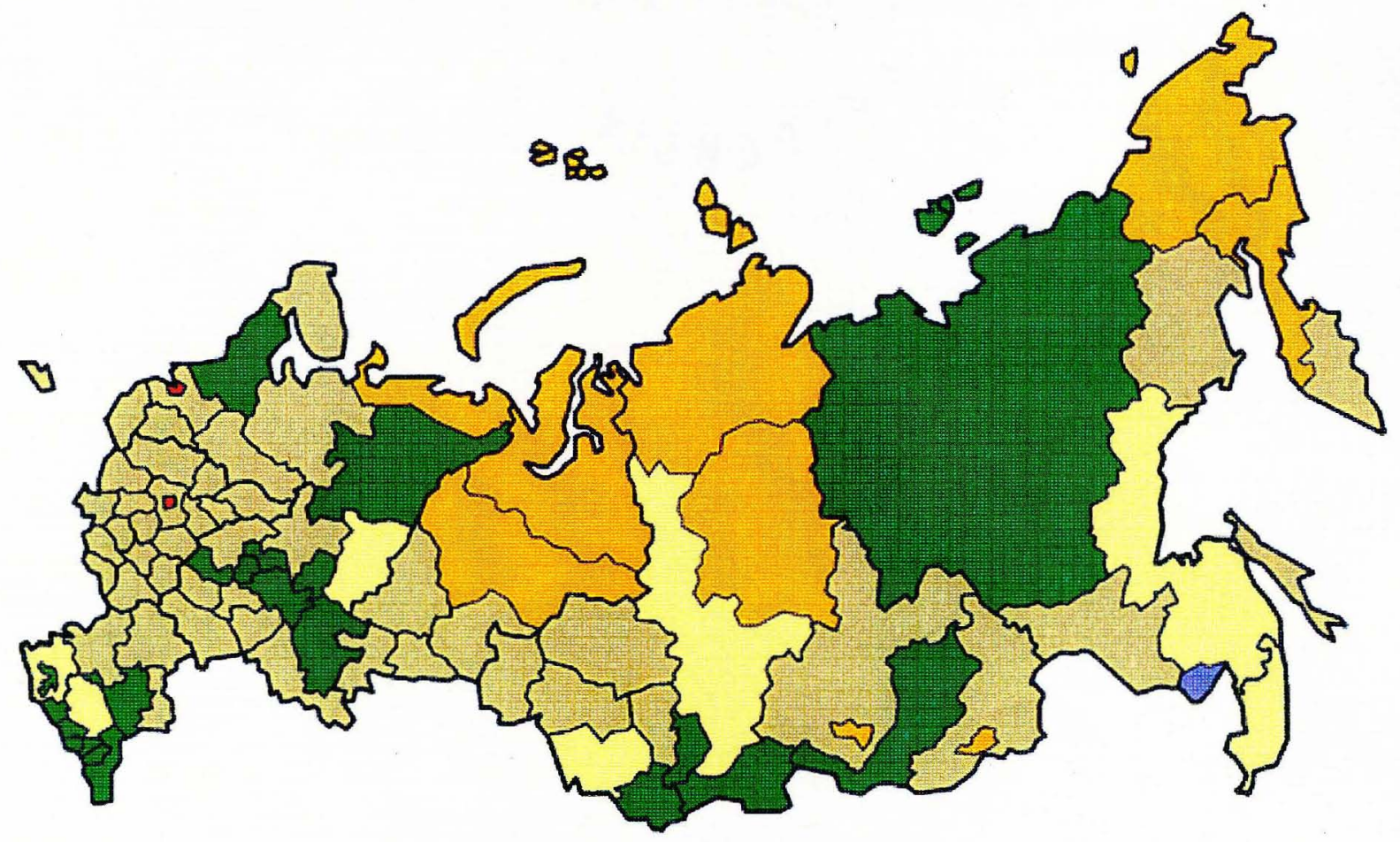

Note. From www wikipedia.com; Red $=$ Federal City; Orange = Autonomous Districts; Blue = Autonomous Province; Yellow $/$ Beige =Territory; Green = Republic; Brown = Province 
Figure 4. Russian Federation and Surrounding Countries

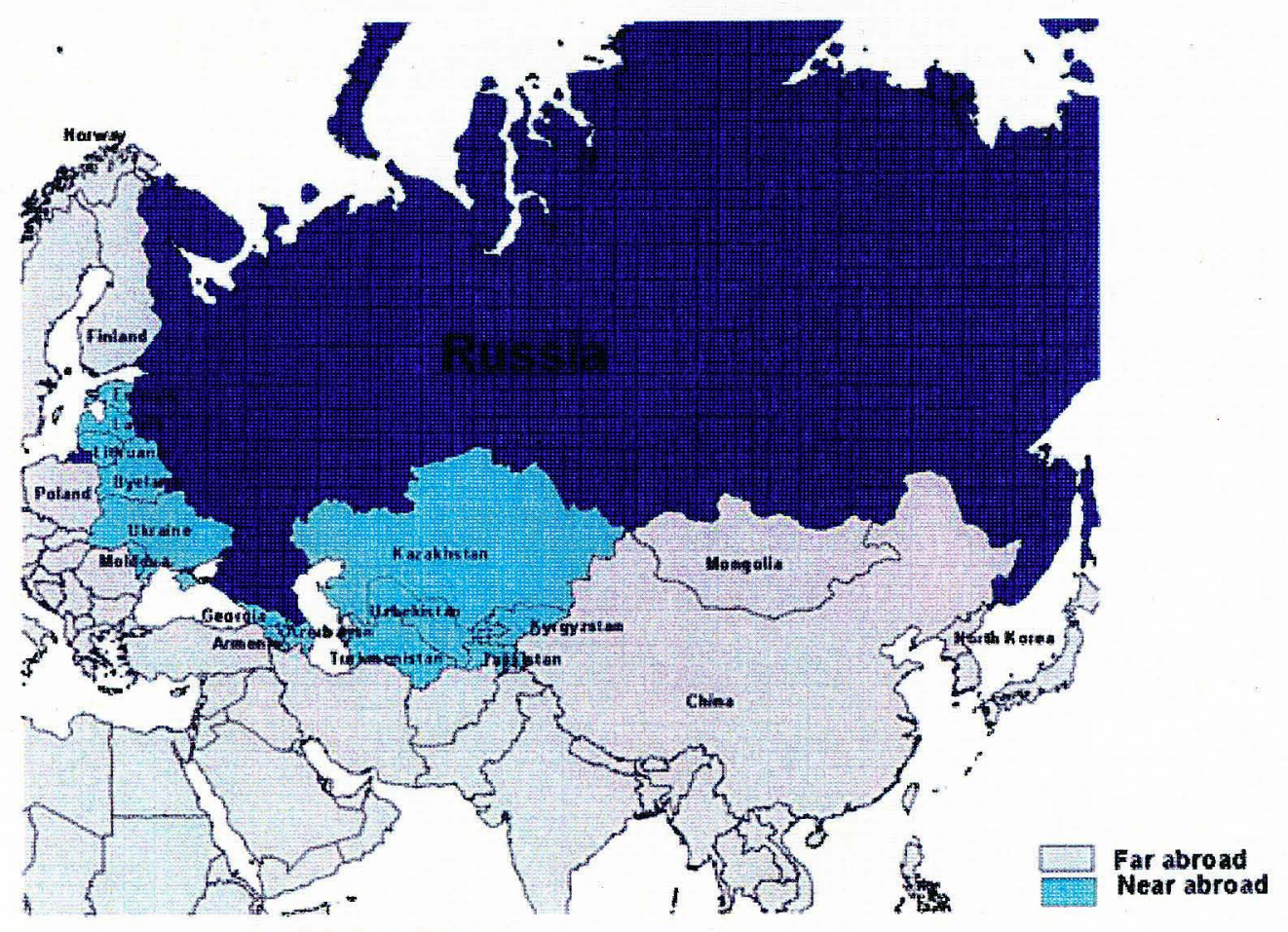

Note. From www.migrationinformation.org 
Table 8. Russian Actors and Influence Groups

\begin{tabular}{|l|l|}
\hline \multicolumn{1}{|c|}{1993} & \\
\hline (1) President & (1) President \\
\hline (2) Gazprom & (2) Financial Actors \\
\hline (3) Electricity Companies & (3) Central Bank \\
\hline (4) Oil Companies & (4) Electricity Companies \\
\hline (5) Central Bank & (5) Power Ministries \\
\hline (6) Federation Council & (6) Gazprom \\
\hline (7) Financial Actors & (7) Armaments exports \\
\hline (8) Mass Media & (8) Oil Companies \\
\hline (9) Criminal Groups & (9) Federation Council \\
\hline (10) Oligarchs & (10) Mass Media \\
\hline
\end{tabular}

Note. Gazprom = companies responsible for exports; increase access for Russia as global trade partner

From Segbers, K. (2001). Actors and interests in a changing Russia. In K. Segbers (Eds.), Post-Soviet patchworks:

Actors and sectors in Russia between accommodation and resistance to globalization. Burlington, VT: Ashgate.

\section{APPENDIX M}


Table 9. Russian Policy History and Status Quo Attitudes

\begin{tabular}{|c|c|}
\hline Immigration Law/Time Period & Purpose and U.S. Attitude \\
\hline $9^{\text {th }}-18^{\text {th }}$ century & Exclusion based on Russian Orthodox religion \\
\hline $19^{\text {in }}$ century & $\begin{array}{l}\text { Czarist rule; expanding borders led to exclusion of new } \\
\text { ethnicities; caste like system formation; increased anti- } \\
\text { Semitism }\end{array}$ \\
\hline Bolshevik Revolution (1917) & Control of migration by government \\
\hline Trotsky's Migration Policy (1917) & First attempt at regulation of movement of peoples \\
\hline Civil War (1919) & Pogroms (massacres) against ethnic minorities \\
\hline $1940 \mathrm{~s}$ & $\begin{array}{l}\text { Departure of Ethnic minorities toward interior; increases in } \\
\text { Pogroms (especially towards Jews); control of E. satellite } \\
\text { countries }\end{array}$ \\
\hline $1950 \mathrm{~s}$ & $\begin{array}{l}\text { East/west migration for economic purposes; ended with } \\
\text { Berlin Wall (1961) }\end{array}$ \\
\hline Years of Stagnation (1964-1985) & $\begin{array}{l}\text { Economic depression; lack of new policies; increased } \\
\text { migration of Jews to US and Israel }\end{array}$ \\
\hline Freedom of Movement Act (1991) & Allowance of Russian citizens to move freely \\
\hline Citizenship Law (1992) & $\begin{array}{l}\text { Redefinition of citizenship; determined all FSU citizens of } \\
\text { Russia; increased governmental change; democratic feel }\end{array}$ \\
\hline Immigration and Control Act (1993) & $\begin{array}{l}\text { Federal Migration Service established; focus on monitoring } \\
\text { and control of migrants }\end{array}$ \\
\hline Law on Entry and Exit (1996) & $\begin{array}{l}\text { Increased penalties for undocumented migration; increased } \\
\text { punishments to undocumented migrants and employers of } \\
\text { undocumented }\end{array}$ \\
\hline Law on Judicial Status of Foreigners (2002) & $\begin{array}{l}\text { Implemented } 2 \text { part registration cards; FMS moved to } \\
\text { Department of the Interior }\end{array}$ \\
\hline Migration Regulations (2003) & $\begin{array}{l}\text { Focus on internal and foreign migration; relocation of } \\
\text { citizens and migrants to depopulated areas of Russia; } \\
\text { attempts to increase human capital of migrants }\end{array}$ \\
\hline
\end{tabular}

Note. From Chudinovskikh, O. (2005). Migration policies in the Russian Federation. Retrieved January 28, 2006, from

Moscow State University Web site: www.unece.org/stats/documents/2005/o1/migration/18.e.ppt. 
APPENDIX N

Table 10. Trigger Events and Policy (1914-1939)

\begin{tabular}{|c|c|c|c|c|c|c|}
\hline $\begin{array}{l}\text { Trigger } \\
\text { World } \\
\text { Events }\end{array}$ & US Policy & $\begin{array}{l}\text { US Model } \\
\text { Application }\end{array}$ & $\begin{array}{l}\text { German } \\
\text { Policy }\end{array}$ & $\begin{array}{l}\text { German } \\
\text { Model } \\
\text { Application }\end{array}$ & $\begin{array}{l}\text { Russian } \\
\text { Policy }\end{array}$ & $\begin{array}{l}\text { Russian } \\
\text { Model } \\
\text { Application }\end{array}$ \\
\hline $\begin{array}{l}\text { World War } \\
\text { I (1914- } \\
1919)\end{array}$ & $\begin{array}{l}\text { Immigration } \\
\text { Act } 1917 \\
\text { Literacy test; } \\
\text { bureau to } \\
\text { Dept. of } \\
\text { Commerce } \\
\text { and Labor; } \\
\text { Asiatic bar } \\
\text { zone; head } \\
\text { tax } \$ 8 \\
\text { Immigration } \\
\text { Act } 1921 \\
\text { Quotas on } \\
1910 \text { census; } \\
\text { preferences } \\
\text { for artists, } \\
\text { intellectuals, } \\
\text { and } \\
\text { professors } \\
\text { Immigration } \\
\text { Act } 1924 \\
\text { Quotas on } \\
1890 \text { census; } \\
\text { WASP focus; } \\
\text { visas and } \\
\text { photographs, } \\
\text { head tax } \$ 9\end{array}$ & $\begin{array}{l}\text { Influence: Anti- } \\
\text { immigrant group } \\
\text { strength increased } \\
\text { Changers: Theodore } \\
\text { Roosevelt x } 2 \text { (191- } \\
1920 \text { ) } \\
\text { Inclusion/Exclusion: } \\
\text { Negative four } \\
\\
\text { Influence: Labor } \\
\text { power; reduction in } \\
\text { migrant labor } \\
\text { Changers: Warren G. } \\
\text { Harding 1920-1923 } \\
\text { Inclusion/Exclusion: } \\
\text { Negative three } \\
\\
\text { Influence: Labor } \\
\text { Unions } \\
\text { Changers: Calvin } \\
\text { Coolidge 1923-1928 } \\
\text { Inclusion/Exclusion: } \\
\text { Negative three }\end{array}$ & $\begin{array}{l}\text { License } \\
\text { Requirement } \\
\text { Policy } 1914 \\
\\
\text { Weimar } \\
\text { Republic } \\
\text { 1920-1923 } \\
\\
\\
\text { Beer Hall } \\
\text { Putsch Nov. } \\
\text { 9, } 1923\end{array}$ & $n$ & $\begin{array}{l}\text { Bolshevik } \\
\text { Revolution; } \\
\text { Lenin to } \\
\text { power } 1917 \\
\text { Trotsky: } 1^{\text {st }} \\
\text { migration } \\
\text { policy } 1917 \\
\text { Civil } \\
\text { War/Famine } \\
1919\end{array}$ & \\
\hline $\begin{array}{l}\text { Great } \\
\text { Depression } \\
1929\end{array}$ & $\begin{array}{l}\text { Stopped } \\
\text { migration } \\
\text { INS to Dept. } \\
\text { of Justice } \\
1933\end{array}$ & & $\begin{array}{l}\text { German } \\
\text { discontent } \\
\text { over WWI } \\
\text { Hitler Nazi } \\
\text { party leader } \\
1932 \\
\\
\text { Hitler } \\
\text { Chancellor } \\
\text { 1-30-33 }\end{array}$ & & $\begin{array}{l}\text { Stalin in } \\
\text { power } 1928 \\
\text { Great } \\
\text { Famine } \\
\text { 1932-1933 }\end{array}$ & \\
\hline
\end{tabular}




\section{APPENDIX $O$}

Table 11. Trigger Events and Policy (1939-1973)

\begin{tabular}{|c|c|c|c|c|c|c|}
\hline $\begin{array}{l}\text { Trigger } \\
\text { World } \\
\text { Events }\end{array}$ & US Policy & $\begin{array}{l}\text { US Model } \\
\text { Application }\end{array}$ & German Policy & $\begin{array}{l}\text { German } \\
\text { Model } \\
\text { Application }\end{array}$ & $\begin{array}{l}\text { Russian } \\
\text { Policy }\end{array}$ & $\begin{array}{l}\text { Russian } \\
\text { Model } \\
\text { Application }\end{array}$ \\
\hline $\begin{array}{l}\text { World } \\
\text { War II } \\
1939- \\
1945\end{array}$ & $\begin{array}{l}\text { Bracero } \\
\text { Program } \\
\text { McCarran } \\
\text { Walter Act } \\
1952 \\
\text { Recodified } \\
\text { pervious policy; } \\
\text { quota on } 1920 \\
\text { census; } \\
\text { removed } \\
\text { Asiatic bar } \\
\text { zone }\end{array}$ & $\begin{array}{l}\text { Influence: TV; media; } \\
\text { attempt at "wet back" } \\
\text { proviso } \\
\text { Changers: McCarthy; } \\
\text { Dwight D. Eisenhower } \\
\text { (1952-1956) } \\
\text { Inclusion/Exclusion: } \\
\text { negative two }\end{array}$ & $\begin{array}{l}\text { Aussiedler } \\
\text { Policy (Ethnic } \\
\text { German Law) } \\
1945 \\
\text { Privileged } \\
\text { migrants granted } \\
\text { citizenship; } \\
\text { assistance with } \\
\text { assimilation; } \\
\text { rights given by } \\
\text { Article } 116 \text { of } \\
\text { Post-war } \\
\text { Constitution } \\
\text { Gastarbeiter } \\
\text { Policy (Guest } \\
\text { worker Policy) } \\
\text { 1951-1973 } \\
\text { Labor } \\
\text { recruitment to fill } \\
\text { open jobs; based } \\
\text { on previous work } \\
\text { agreements; 1- } \\
\text { 3year rotation; } \\
\text { GDR similar } \\
\text { project }\end{array}$ & $\begin{array}{l}\text { Influence: } \\
\text { Changers: } \\
\text { Inclusion/ } \\
\text { Exclusion: } \\
\text { Consequenc } \\
\text { e: migrants } \\
\text { staying in } \\
\text { country past } \\
\text { work permits }\end{array}$ & $\begin{array}{l}\text { Deportation of } \\
\text { ethnic } \\
\text { minorities } \\
1943 \\
\text { Official } \\
\text { Communist } \\
\text { party } 1952\end{array}$ & \\
\hline $\begin{array}{l}\text { Cold } \\
\text { War } \\
1946- \\
1991\end{array}$ & $\begin{array}{l}\text { Marshall Plan } \\
\text { Hart-Cellar } \\
\text { Act/Immigrati } \\
\text { on Act of } 1965 \\
\text { Switch from } \\
\text { social to } \\
\text { political } \\
\text { reasons for } \\
\text { policy; end of } \\
\text { quotas; cap on } \\
\text { western } \\
\text { hemisphere; } \\
\text { congressional } \\
\text { committee } \\
\text { focus }\end{array}$ & $\begin{array}{l}\text { Influence: Media } \\
\text { magazine use; media } \\
\text { overall } \\
\text { Changers: } \\
\text { Lyndon Baines } \\
\text { Johnson- Great } \\
\text { Society } 1964 \\
\text { Inclusion/Exclusion: } \\
\text { zero } \\
\text { Consequence: chain } \\
\text { migration }\end{array}$ & Berlin Wall 1961 & . & $\begin{array}{l}\text { Control of } 7 \\
\text { Eastern } \\
\text { European } \\
\text { Satellite } \\
\text { Counties }\end{array}$ & \\
\hline
\end{tabular}


APPENDIX P

Table 12. Trigger Events and Policy (1973-present)

\begin{tabular}{|c|c|c|c|c|c|c|}
\hline $\begin{array}{l}\text { Trigger } \\
\text { World } \\
\text { Events }\end{array}$ & US Policy & $\begin{array}{l}\text { US Model } \\
\text { Application }\end{array}$ & $\begin{array}{l}\text { German } \\
\text { Policy }\end{array}$ & $\begin{array}{l}\text { German } \\
\text { Model } \\
\text { Application }\end{array}$ & $\begin{array}{l}\text { Russian } \\
\text { Policy }\end{array}$ & $\begin{array}{l}\text { Russian Model } \\
\text { Application }\end{array}$ \\
\hline $\begin{array}{l}\text { OPEC Oil } \\
\text { Crises } \\
1973-1975 \\
1979- \\
1980\end{array}$ & $\begin{array}{l}\text { Undocumen } \\
\text { ted Focus }\end{array}$ & & $\begin{array}{l}\text { End of } \\
\text { Gastarbeiter } \\
\text { Program }\end{array}$ & & $\begin{array}{l}\text { Years of } \\
\text { Stagnation } \\
1964-1985\end{array}$ & \\
\hline $\begin{array}{l}\text { Collapse } \\
\text { of USSR } \\
(1989- \\
1991)\end{array}$ & $\begin{array}{l}\text { Violent } \\
\text { Crimes } \\
\text { Control } \\
\text { and Law } \\
\text { Enforceme } \\
\text { nt Act 1994 } \\
\text { Criminal } \\
\text { alien } \\
\text { center; } \\
\text { increased } \\
\text { deportation, } \\
\text { visa } \\
\text { violation } \\
\text { infractions; } \\
\text { non- } \\
\text { immigrant } \\
\text { "S" visa }\end{array}$ & $\begin{array}{l}\text { Influence: } \\
\text { international focus; } \\
\text { negative view by } \\
\text { media of migrants } \\
\text { Changers: Bill } \\
\text { Clinton } \\
\text { Inclusion/Exclusion: } \\
\text { negative one } \\
\text { Consequences: use } \\
\text { of migration policy for } \\
\text { terrorism reasons }\end{array}$ & $\begin{array}{l}\text { Reunification } \\
\text { Joining } \\
\text { European } \\
\text { Union }\end{array}$ & & $\begin{array}{l}\text { Freedom of } \\
\text { Movement } \\
\text { Policy } 1991 \\
\\
\text { Citizenship } \\
\text { Law } 1992 \\
\text { All citizens of } \\
\text { FSU states } \\
\text { Immigration } \\
\text { and Control } \\
\text { Act } 1993\end{array}$ & $\begin{array}{l}\text { Influence: W. } \\
\text { Europe; part } \\
\text { Communist } \\
\text { restriction } \\
\text { Changers: } \\
\text { Gorbachev } \\
\text { Inclusion/ } \\
\text { Exclusion: } \\
\text { positive 5 } \\
\text { Influence: } \\
\text { democratic } \\
\text { feelings; } \\
\text { governmental } \\
\text { changes } \\
\text { Changers: Yeltsin } \\
\text { Inclusion/ } \\
\text { Exclusion: zero }\end{array}$ \\
\hline $\begin{array}{l}\text { World } \\
\text { Trade } \\
\text { Center } \\
\text { Attack } \\
2001\end{array}$ & $\begin{array}{l}\text { Homeland } \\
\text { Security } \\
\text { Act } 2002 \\
\text { Dismantled } \\
\text { INS; new } \\
\text { bureaus: } \\
\text { Bureau of } \\
\text { Customs } \\
\text { and Border } \\
\text { Patrol; } \\
\text { Bureau of } \\
\text { Immigration } \\
\text { and } \\
\text { Customs } \\
\text { Enforcemen } \\
\text { t; Bureau of } \\
\text { Citizenship } \\
\text { and } \\
\text { Immigration } \\
\text { Services }\end{array}$ & $\begin{array}{l}\text { Influence: } \\
\text { conservatives vs. } \\
\text { liberals } \\
\text { Changers: George } \\
\text { W. Bush } \\
\text { Inclusion/Exclusion: }\end{array}$ & $\begin{array}{l}\text { First } \\
\text { Immigration } \\
\text { Policy } \\
\text { (zuwanderun } \\
\text { gsgesetz) } \\
\text { 2004 } \\
\text { regulation } \\
\text { office will } \\
\text { integrate } \\
\text { efforts and } \\
\text { migration; less } \\
\text { focus on } \\
\text { Federal } \\
\text { Interior } \\
\text { ministry; office } \\
\text { now titled } \\
\text { Commission } \\
\text { for Migration, } \\
\text { Refugees, and } \\
\text { Immigration; } \\
\text { increased } \\
\text { ability } \\
\text { deportation }\end{array}$ & $\begin{array}{l}\text { Start of } \\
\text { undocumente } \\
d \text { migrants } \\
\text { database; } \\
\text { increased } \\
\text { numbers of } \\
\text { undocumente } \\
d \text { migrants }\end{array}$ & $\begin{array}{l}\text { Law on } \\
\text { Judicial } \\
\text { Status of } \\
\text { Foreigners } \\
2002 \\
\text { Foreign } \\
\text { registration } \\
\text { cards } \\
\\
\\
\text { Migration } \\
\text { Regulations } \\
\text { 2003 } \\
\text { Internal vs. } \\
\text { foreign } \\
\text { migration } \\
\text { focus: } \\
\text { increased } \\
\text { attempt to re- } \\
\text { populate } \\
\text { North \& East }\end{array}$ & $\begin{array}{l}\text { Influence: } \\
\text { Chernenko (head } \\
\text { of migration } \\
\text { service); } \\
\text { information from } \\
\text { census } \\
\text { Changers: Putin } \\
(2000) \\
\text { Inclusion/ } \\
\text { Exclusion: } \\
\text { negative one } \\
\text { Influence: } \\
\text { negative view of } \\
\text { status quo; } \\
\text { president; financial } \\
\text { companies; bank; } \\
\text { electric company; } \\
\text { power ministry } \\
\text { Changers: Putin } \\
\text { Inclusion/ } \\
\text { Exclusion: } \\
\text { negative one }\end{array}$ \\
\hline
\end{tabular}




\section{APPENDIX Q}

Figure 5. United States Policy Response Continuum

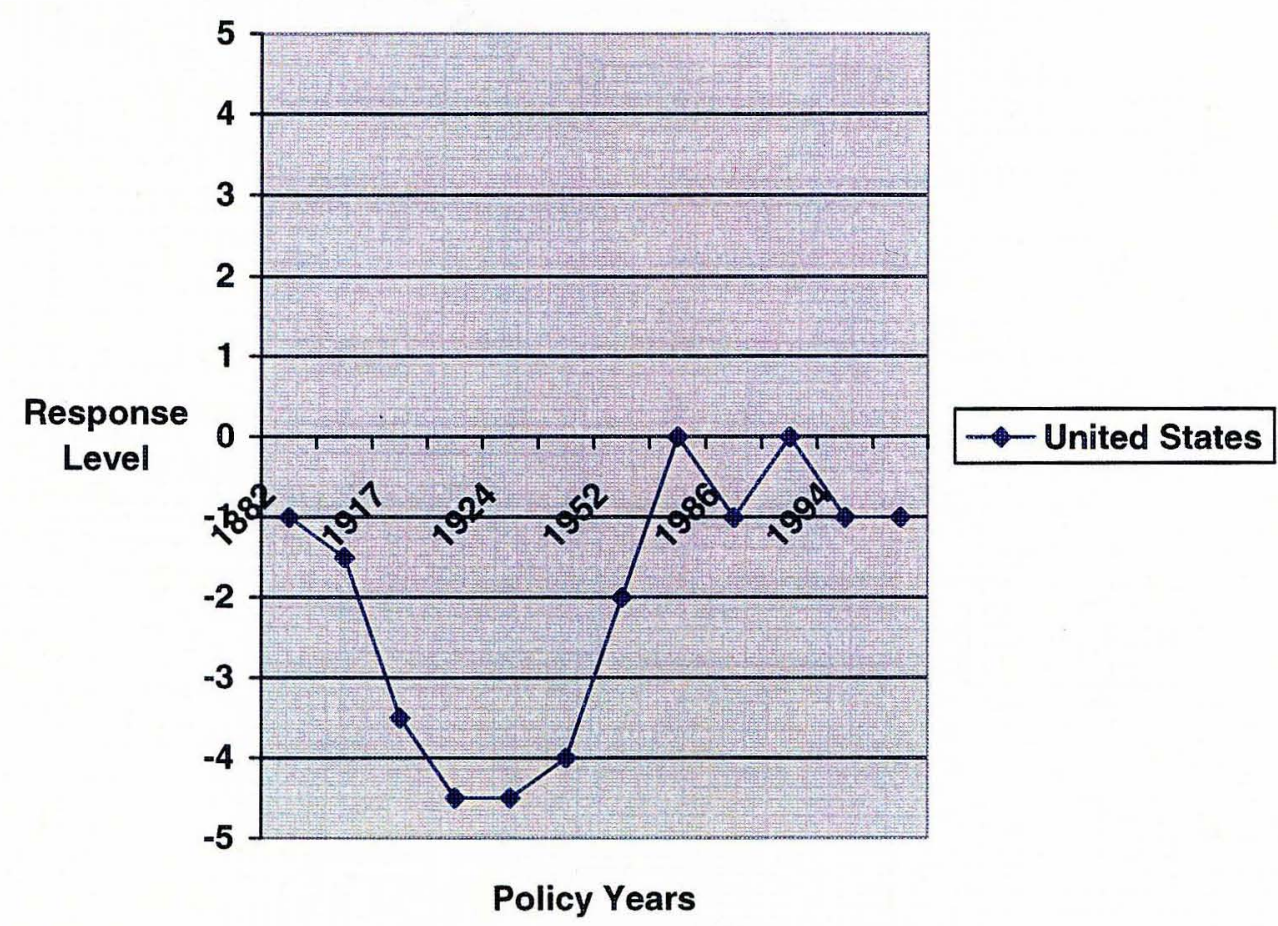




\section{APPENDIX R}

Figure 6. German Policy Response Continuum

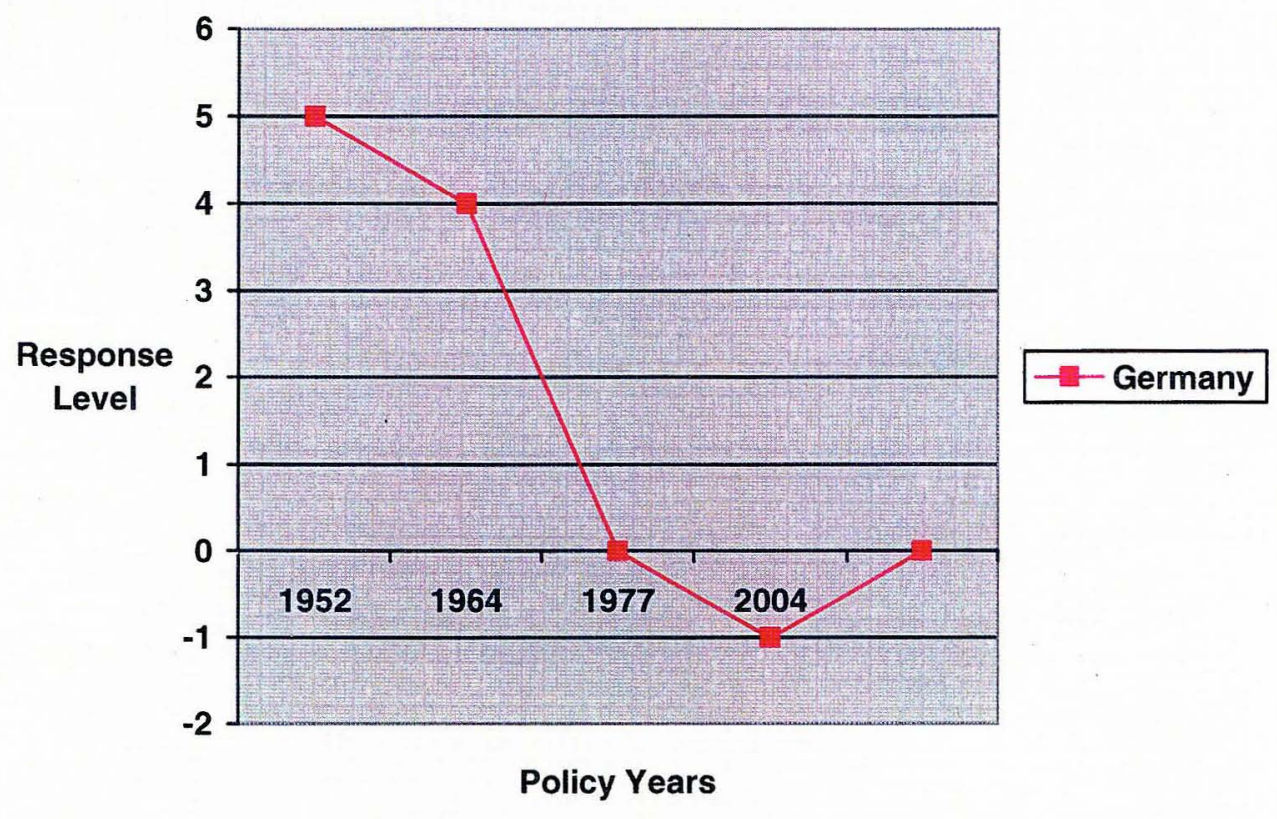




\section{APPENDIX S}

Figure 7. Russian Policy Response Continuum

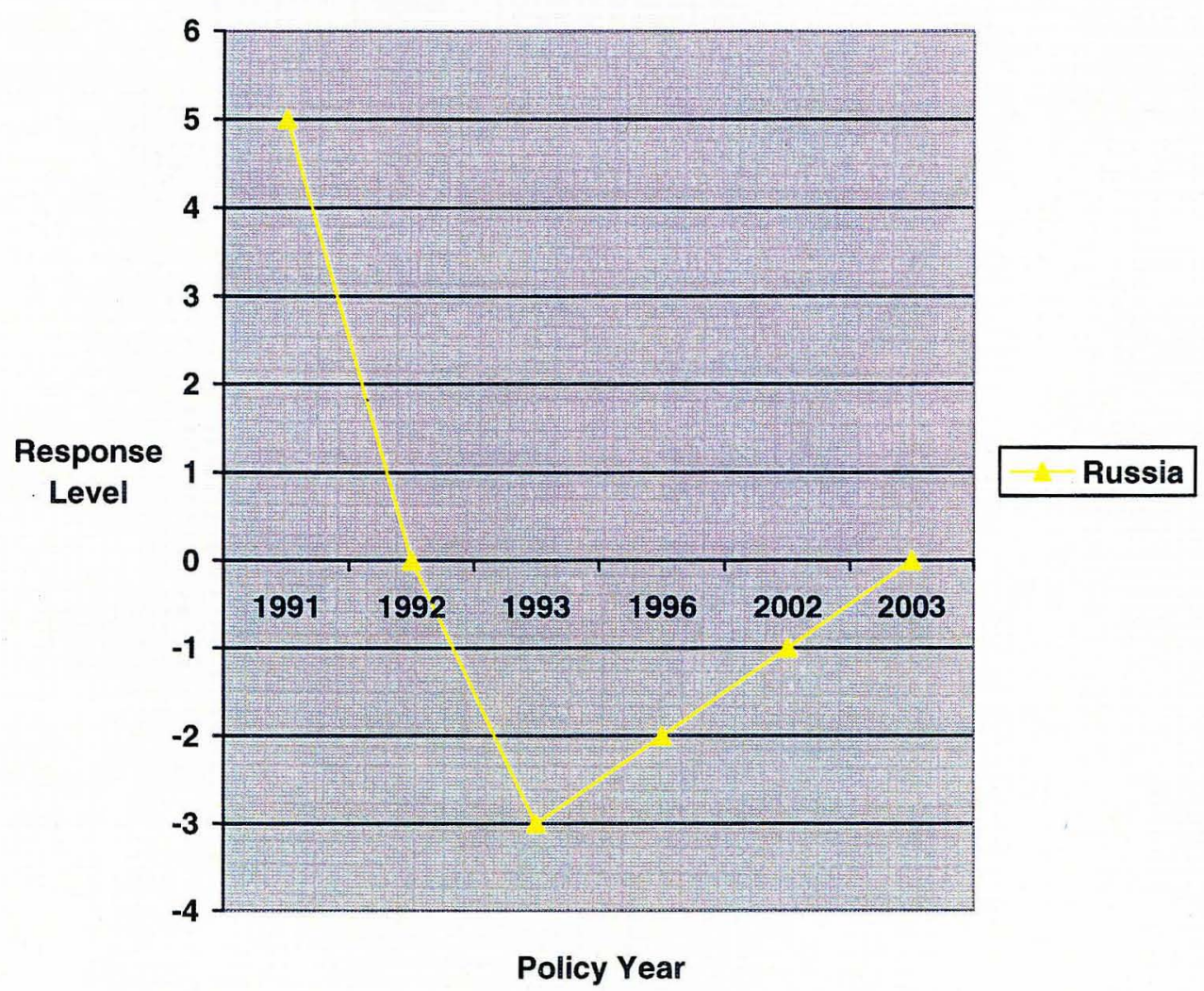




\section{APPENDIX T}

Table 13. Model Strengths and Weaknesses

\begin{tabular}{|c|c|}
\hline Model Strengths & Model Weaknesses \\
\hline $\begin{array}{l}\text { (1) Application of model elements to policy allows for study } \\
\text { of all impinging factors that affect writing of policy }\end{array}$ & $\begin{array}{l}\text { 1) Model application only applicable to countries with "data" } \\
\text { available for analysis (both on theoretical and empirical } \\
\text { level of analysis) }\end{array}$ \\
\hline $\begin{array}{l}\text { (2) Application of model elements to policy allows for study } \\
\text { of all impinging factors that affect policy implementation }\end{array}$ & \\
\hline (3) Model useful for application to single policy & \\
\hline $\begin{array}{l}\text { (4) Model useful for application to multiple policies over } \\
\text { period of time }\end{array}$ & \\
\hline (5) Model useful for application of policy cross-culturally & \\
\hline $\begin{array}{l}\text { (6) Model ability to target unintended consequences of } \\
\text { policy }\end{array}$ & \\
\hline $\begin{array}{l}\text { (7) Policy Response Continuum allows for analysis of } \\
\text { policy trends over time by country }\end{array}$ & \\
\hline $\begin{array}{l}\text { (8) Policy Response Continuum allows for analysis of } \\
\text { policy trends over time cross-culturally }\end{array}$ & \\
\hline $\begin{array}{l}\text { (9) Exploratory analysis of model allows for future } \\
\text { longitudinal trend analysis using census data }\end{array}$ & \\
\hline
\end{tabular}




\section{APPENDIX U}

Table 14. Preparation at Practice, Education, and Policy Levels

\begin{tabular}{|c|c|}
\hline Practice & $\begin{array}{l}\text { - } \quad \text { Require continuing education units in diversity } \\
\text { - Increase number of cultural competence questions on licensure exams } \\
\text { - Encourage practitioner so increase cultural competence through focusing } \\
\text { on this as area of specialization on insurance panel applications }\end{array}$ \\
\hline Education & $\begin{array}{l}\text { - Mandate section on immigrants and refugees in diversity courses } \\
\text { - Infuse immigrant/refugee information into all levels of curriculum } \\
\text { - Increase schools of SW providing elective courses of migration } \\
\text { (micro/macro) } \\
\text { - Increase student exchange opportunities } \\
\text { - Increase practicum placements that combine micro/macro levels of } \\
\text { - Embrace acceptance of all forms of knowledge (quantitative, qualitative, } \\
\text { and theoretical) }\end{array}$ \\
\hline Policy & $\begin{array}{l}\text { - Provide macro policy classes focusing on immigrant/refugee issues } \\
\text { - Increase BSW and MSW opportunities for advocacy within safety of } \\
\text { classroom setting } \\
\text { - Increase MSW coursework on analyzing policy in the classroom }\end{array}$ \\
\hline
\end{tabular}




\section{APPENDIX V}

Table 15. Implementation at Practice, Education, and Policy Levels

\begin{tabular}{|c|c|}
\hline Practice & $\begin{array}{l}\text { - } \quad \text { Continued study of diverse groups } \\
\text { - } \quad \text { Study of foreign language of clients in needed areas of practice } \\
\text { - } \quad \text { population in local and state areas } \\
\text { - Involvement in grass roots level change of organizations }\end{array}$ \\
\hline Education & $\begin{array}{l}\text { - } \quad \text { Analysis (quantitative, qualitative, and theoretical) on migration by } \\
\text { - Seeking federal, state, and foundation grant dollars } \\
\text { - Presenting at professional conferences on migration topics } \\
\text { - Publishing articles/books on migration topics }\end{array}$ \\
\hline Policy & $\begin{array}{l}\text { - Involvement in local/state/national boards relating to migration } \\
\text { - } \quad \text { Advocacy at local/state/national levels to influence policy decisions } \\
\text { - Presenting research knowledge beyond professional articles and } \\
\text { presentations to policy makers at local/state/national levels }\end{array}$ \\
\hline
\end{tabular}




\section{CURRICULUM VITAE}

\section{Amy C. Cappiccie, LCSW, Ph.D.}

5611 Oxford Ct., Apt. 832, Louisville, Kentucky 40291

Home: (502)810-7727 or Work: (502)852-4769

ACappiccie@aol.com or accapp01@louisville.edu

\section{EDUCATION}

Doctor of Philosophy in Social Work, University of Louisville, Kent School of Social Work, Graduation May 2006

Dissertation: Title: "A Proposed Model of Immigration Evolution applied to the United States, Germany, and Russia"
Chair:
Dr. Thomas Lawson, Director of International
Program, Kent School of Social Work
Committee:
Dr. Pam Yankeelov, Kent School of Social Work
Dr. Joseph Brown, Kent School of Social Work
Dr. Steve Drury, Capital University
Dr. Jim Clark, University of Kentucky

Master of Science in Social Work, University of Louisville, Kent School of Social Work, 5/99

Bachelor of Arts in Psychology, Magna cum Laude, Kentucky Wesleyan College, 5/97

\section{LICENSURE AND CERTIFICATIONS}

Licensed Clinical Social Worker- State of Kentucky, 4/03

EMDR, Level I, Certification, 5/99

\section{RESEARCH INTERESTS}


Immigration and emigration policy, immigrant issues, cross-cultural studies, human diversity, human trafficking, mental illness in children and adolescents, innovative approaches to clinical practice with children and adolescents, trauma

\section{RESEARCH EXPERIENCE}

\section{University of Louisville}

Recruitment of social work students and professionals on HRSA Grant

8/04-present

- Currently coordinating recruitment of Social Work students and professionals for HRSA Training Grant $(\$ 600,000)$. The goal of this grant is to assist older individuals to maintain in their homes for longer periods of time

- Participated in community meetings to introduce the grant to potential Social Work student and professional recruits

- Designed and coordinated online newsletter to promote current phase of the grant process as well as most recent information on geriatric information

\section{University of Louisville}

Research Independent Study

1/05-present

- With colleague wrote scale entitled "Cappiccie/Freese Attitude Towards Immigrants Inventory" (CFARII)

- Examined responses to the scale in the United States, Hungary, and Germany

- Beginning phases of scale validation using Factor Analysis

\section{University of Louisville}

First Year Research Project 3/03-5/05

- Literature review of previous research on well-being of immigrant children

- Proposed variables (obtained through multiple regression) to use for future analysis concerning immigrant children

University of Louisville

IMPACT Research Project

1/99-5/99 
- Examination of KY regions' IMPACT Program to determine changes in levels of aggression and depression in Severely Emotional Disturbed (SED) children

\section{TEACHING INTERESTS}

Direct Clinical Practice, Mental Health, Psychopathology, Policy, Human Diversity,

Human Behavior in the Social Environment, Social Work Practice with Immigrant

Populations, Social Work Practice with Diverse Populations

\section{TEACHING EXPERIENCE}

\section{University of Louisville}

Co-Teaching Experience

8/05-5/06

- Masters Level Direct Practice Class, Topic: Clinical Assessment, September 27, 2005

- Masters Level Direct Practice Class, Topic: Family Systems Skills, October 4, 2005

- Masters Level Direct Practice Class, Topic: Social Work Ethics, November 15, 2005

- Masters Level Direct Practice II Class, Topic: Intro to Organizations, January 2006

- Masters Level Direct Practice II Class, Topic: Macro Organizational Connections, February 7, 2006

\section{University of Louisville}

- Masters level Independent Study Seminar "Mental Health", Summer, 2004

- Masters level Independent Study Seminar "Death and Dying", Summer, 2004

- Masters level Independent Study Seminar "Social Work and Corrections", Summer, 2004

\section{Kentucky Wesleyan College}


- Bachelor level "Peoples of the World", Spring 2003

- Bachelor level "Peoples of the World", Fall 2002

- Bachelor level "The Family", Fall, 2000

- Bachelor level "The Family", Fall, 1999

\section{INTERNATIONAL SOCIAL WORK EXPERIENCE}

\section{Student Exchange Experiences}

- Munich, Germany and Trento, Italy, March 2004

- Cape Town and Johannesburg, South Africa, October 2004

- Moscow and Belgorod, Russia, August 2005

Future International Teaching Experience

- China, May 2006

\section{PROFESSIONAL EXPERIENCE}

University of Louisville, Kent School of Social Work

8/04-present

\section{Continuing Education Director}

- Planning and organizing Continuing Education programming for Social Workers and other allied health disciplines

- Budgeting for the Continuing Education program

- Provide planning and organization skills for two grants maintained by the University of Louisville (a HRSA Geriatric Grant and a HRSA Health Grant)

Counseling Associates, Owensboro, $K Y$

8/99-8/04

Therapist

- Mental health therapist providing individual, family, and group therapy

- Providing therapy in office, in school, and in-home settings

- Practice specialization in children, adolescents, families, as well as adults with trauma/grief issues

RiverValley Behavioral Health, IMPACT Program

Service Coordinator 
- Assessing, monitoring, brokering, advocating, and implementing services for Axis I diagnosed children

- Planned and implemented yearly summer program for IMPACT children

- Supervision of direct service staff

RiverValley Behavior Health Hospital

5/95-5/97

Youth Care Specialist

- Monitoring adolescents on psychiatric unit to maintain therapeutic milieu

- Facilitating goal groups

- Charting behavior

\section{PROFESSIONAL PRESENTATIONS}

- Cappiccie, A.C. (Spring, 2004) Invited to present on "Evidenced Based Practice" at Counseling Associates

- Cappiccie, A.C. (August, 2003) Invited to present on "Suicidal Indicators in College Students" for Student Life at Kentucky Wesleyan College

- Cappiccie, A.C. (Spring, 2003) Invited to present on "Stress Management" for the Leadership Program at Kentucky Wesleyan College

- Cappiccie, A.C. (August, 2002) Invited to present on "Mental Health Indicators in College Students" for Student Life at Kentucky Wesleyan College

- Cappiccie, A.C. (Fall, 2000) Invited to present on the topic "Interpreting the Myers-Briggs" for the Leadership Program at Kentucky Wesleyan College

\section{PROFESSIONAL PRESENTATIONS AND PUBLICATION IN PROGRESS}

- Cappiccie, A.C. CSWE 2006 (February 14-17) Abstract submitted and accepted entitled "Inherent Ethical Dilemma: National Sovereignty versus Basic Human Rights"

- Moore, S. \& Cappiccie, A.C. (February 2006) presentation at University of Louisville entitled "Healing and the Future for Hurricane Katrina" 
- Cappiccie, A.C. IFSW Munich Conference (July 2006) abstract entitled "Inherent Ethical Dilemma: National Sovereignty versus Basic Human Rights"

- Cappiccie, A.C. \& Stone, R. Article entitled 'Support Systems' Effect on the Well-being of Immigrant Children" submitted to Child Development

- Cappiccie, A.C. Article entitled "Social Problem Analysis: From Unequal Service Access to Child Interpreting Consequences" submitted to Youth and Society

- Work in progress entitled "Scale Development Pilot for the Cappiccie/Freese Attitudes Toward Immigrants Inventory (CFARII)"

\section{COMMUNITY SERVICE INVOLVMENT}

World Communities of Louisville

World Communities of Louisville, Secretary

ESL Instructor, Owensboro, $K Y$ 8/04-present 1/04-present $5 / 01-8 / 04$

\section{ORGANIZATIONS}

NASW

CSWE
$5 / 97-5 / 03$

9/05-present 
